\title{
DOEFR/6/726--T2
}

\section{Re-Evaluation of Total and Umkehr Ozone Data from NOAA-CMDL Dobson Spectrophotometer Observatories}

W.D. Komhyr, D.M. Quincy, R.D. Grass and G.L. Koenig

CIRES, University of Colorado, Boulder, Colorado 80309, and NOAA-Climate Monitoring and Diagnostics Laboratory, Boulder, Colorado 80303

December 1995

OSTRIBUTION OF THIS DOCUMENT IS UMLIMTED

MASTER

Final Report Prepared for the U.S.A. Department of Energy, Environmental

Science Services Division, Washington D.C., Under Interagency Agreement No.

DE-A103-93ER61726 


\title{
Re-Evaluation of Total and Umkehr Ozone Data from NOAA-CMDL Dobson Spectrophotometer Observatories
}

\author{
W.D. Komhyr, D.M. Quincy, R.D. Grass and G.L. Koenig \\ CIRES, University of Colorado, Boulder, Colorado 80309, and NOAA-Climate \\ Monitoring and Diagnostics Laboratory, Boulder, Colorado 80303
}

December 1995

Final Report Prepared for the U.S.A. Department of Energy, Environmental Science Services Division, Washington D.C., Under Interagency Agreement No. DE-A103-93ER61726 


\section{DISCLAIMER}

This report was prepared as an account of work sponsored by an agency of the United States Government. Neither the United States Government nor any agency thereof, nor any of their employees, makes any warranty, express or implied, or assumes any legal liability or responsibility for the accuracy, completeness, or usefulness of any information, apparatus, product, or process disclosed, or represents that its use would not infringe privately owned rights. Reference herein to any specific commercial product, process, or service by trade name, trademark, manufacturer, or otherwise does not necessarily constitute or imply its endorsement, recommendation, or favoring by the United States Government or any agency thereof. The views and opinions of authors expressed herein do not necessarily state or reflect those of the United States Government or any agency thereof. 


\section{DISCLAIMER}

Portions of this document may be illegible electronic image products. Images are produced from the best available original document. 


\section{CONTENTS}

1. Introduction 2

2. NOAA Dobson Specrtophotometer Ozone Observations Program 3

2.1 Total Ozone Observations 3

2.2 Umkehr Observations 5

3. Total Ozone Data Re-evaluation 7

3.1 Total Ozone Data Re-evaluation Handbook 8

3.2 NOAACMDL Re-evaluated Total Ozone Data Archive 9

3.3 Brief Observing Program Histories 13

3.3.1 Amundsen-Scott, Antarctica 13

3.3.2 Byrd, Antarctica 14

3.3.3 Fairbanks, Alaska 15

3.3.4 Hallett, Antarctica 16

3.3.5 Haute Provence, France 16

$\begin{array}{ll}\text { 3.3.6 Huancayo, Peru } & 17\end{array}$

3.3.7 Lauder, New Zealand 19

3.3.8 Perth, Australia 19

3.3.9 Poker Flat, Alaska $\quad 20$

3.3.10 Puerto Montt, Chile 21

3.3.11 U.S.A. Mainland Dobson Instrument Stations, Mauna,Loa, Hawaii, and Samoa, South Pacific 22

4. Umkehr Data Re-evaluation 22

5. WODC Re-evaluated Total Ozone Data Archive 27

6. Re-evaluation of Observational Umkehr Data 31

7. Acknowledgements 32

8. References 32

Appendix A: Dobson Data Re-evaluation Handbook, Section II: Re-evaluation of Instrument Constants

Appendix B: Sample Record of Dobson spectrophotometrer Standard and Mercury Lamp Tests Data, Wallops Island, VA, 1966-1995

Appendiix C: Sample Archived Dobson Spectrophotometer Optical Wedge Calibration Data

Appendix D: Sample Archived Dobson Spectrophotometer Calibration Data

Appendix E: Sample Archived Re-evaluated Total Ozone Data 


\title{
Re-Evaluation of Total and Umkehr Ozone Data from NOAA-CMDL Dobson Spectrophotometer Observatories
}

\author{
W.D. Komhyr, D.M. Quincy, R.D.Grass and G.L.Koenig
}

\section{Introduction}

This report describes work performed under U.S.A. Department of Energy (D.O.E.), Environmental Science Services Division, Interagency Agreement No. DE-A103-93ER61726, to improve the quality of total ozone and Umkehr data obtained in the past at the NOAA Climate Monitoring and Diagnostics Laboratory (and its predecessor laboratories') Dobson spectrophotometer ozone observatories. The research stemmed from D.O.E.'s solicitation published in the Federal Register, Volume 58, No. 6, Monday, January 11, 1993, for applications to support the DOE evaluation of atmospheric ozone trends and distributions. Rationale justifying the need for the data re-evaluation is amply described in D.O.E. Report DOE-ER-0575T entitled "Overview of DOE Atmospheric Chemistry Ozone Project".

We present results of total ozone data re-evaluations for ten stations: Byrd, Antarctica $\left(80.0^{\circ} \mathrm{S}, 119.5^{\circ} \mathrm{W}\right)$; Fairbanks, Alaska $\left(64.8^{\circ} \mathrm{N}, 147.9^{\circ} \mathrm{W}\right)$; Hallett, Antarctica $\left(72.3^{\circ} \mathrm{S}, 170.2^{\circ} \mathrm{E}\right)$; Huancayo, Peru $\left(12.1^{\circ} \mathrm{S}, 75.3^{\circ} \mathrm{W}\right)$; Haute Provence, France $\left(43.9^{\circ} \mathrm{N}, 5.7^{\circ} \mathrm{E}\right)$; Lauder, New Zealand $\left(45.1^{\circ} \mathrm{S}, 169.7^{\circ} \mathrm{E}\right)$; Perth, Australia $\left(31.9^{\circ} \mathrm{S}, 116.0^{\circ} \mathrm{E}\right)$; Poker Flat, Alaska $\left(65.1^{\circ} \mathrm{N}, 147.5^{\circ} \mathrm{W}\right)$; Puerto Montt, Chile $\left(41.5^{\circ} \mathrm{S}, 72.8^{\circ} \mathrm{W}\right)$; and South Pole, Antarctica $\left(90.0^{\circ} \mathrm{S}, 24.8^{\circ} \mathrm{W}\right)$. The improved data will be submitted in early 1996 to the World Meteorological Organization (WMO) World Ozone Data Center (WODC), Atmospheric Environment Service, 4905 Dufferin Street, Downsview, Ontario, Canada M3H5T4 for archiving. Considerable work has been accomplished, also, in reevaluating Umkehr data from seven of the stations, viz., Huancayo, Haute Provence, Lauder, Perth, Poker Flat, Boulder, Colorado $\left(40.0^{\circ} \mathrm{N}, 105.3^{\circ} \mathrm{W}\right)$; and Mauna Loa, Hawaii $\left(19.5^{\circ} \mathrm{N}, 155.6^{\circ} \mathrm{W}\right)$.

Because of the convening of the 1994 WMO Ozone Trends Panel, a need arose early in 1994 for updating the re-evaluation of NOAA total ozone data from currently operating stations that have long-term records dating back to the 1960 s and $1970 \mathrm{~s}$. The stations are Bismarck, North Dakota $\left(46.8^{\circ} \mathrm{N}, 100.8^{\circ} \mathrm{W}\right)$; Boulder, Colorado; Caribou, Maine (46.9 $\left.\mathrm{N}, 68.0^{\circ} \mathrm{W}\right)$; Mauna Loa, Hawaii: Nashville, Tennessee $\left(36.2^{\circ} \mathrm{N}, 86.6^{\circ} \mathrm{W}\right)$; Samoa, South Pacific $\left(14.3^{\circ} \mathrm{S}\right.$, $\left.170.6^{\circ} \mathrm{W}\right)$; and Wallops Island, Virginia $\left(37.9^{\circ} \mathrm{N}, 75.5^{\circ} \mathrm{W}\right)$. As part of the overall data optimization effort, data re-evaluation for these stations was updated through December 31, 1994. Details concerning the re-evaluation of data from these stations are described in a report that is in preparation. 


\section{NOAA Dobson Spectrophotometer Ozone Observations Program}

\section{$2.1 \quad$ Total Ozone Observations}

Ozone observations with Dobson spectrophotometers date back to the early 1930s. The program gained impetus during the International Geophysical Year (IGY, 1957-1959), with the number of stations around the globe increasing to the present day 80-90. Dobson instruments are manufactured in Oxford, England, and calibrated there under adverse meteorological and air pollution conditions. Because, also, Dobson instrument observing programs throughout the world have generally been relegated low priority, data quality in the past was often not high. For example, at International Dobson Instrument Comparisons held in Siofok, Hungary, in 1967, disagreement in measured ozone values among several instruments spanned the range of $15 \%$. At similar instrument comparisons held in Belsk, Poland, in 1974, ozone values for six of ten instruments agreed in the mean to $\pm 4 \%$, but the mean errors for the four other instruments ranged from 6-16\%.

The U.S.A. (originally U.S. Weather Bureau, then ESSA, now NOAA) Dobson instrument network grew from one-half dozen sites during the IGY to a total of 28 stations, 16 of which are currently operating. Several of these are foreign cooperatives. Milestones of the program since the early 1960 s are the following:

(a) The U.S.A. Dobson ozone spectrophotometers were revamped optically and electronically in the early 1960 s, and all instruments were calibrated at that time with a newly established U.S.A. Standard Dobson Spectrophotometer 83. Since then, all NOAA instruments have been periodically calibrated with instrument No. 83 (or with a Secondary Standard Spectrophotometer 65). The long-term ozone measurement precision of instrument 83 had been maintained at $\pm 0.5 \%$ through 1987 [Komhyr et al., 1989] and is now $\pm 1 \%$. In the early 1960s, also, detailed Dobson instrument operating instructions were prepared for use at the U.S.A. station network. These instructions [Komhyr, 1980] were subsequently adopted by the WMO for use in the global Dobson spectrophotometer network.

(b) With formation of the WMO Ozone Research and Monitoring Program in the mid 1970s, the WMO became actively involved in the global Dobson instrument measurements program. Under auspices of the WMO, an International Comparison of Dobson Spectrophotometers was conducted by NOAA in Boulder in 1977 [Komhyr et al., 1981]. NOAA Dobson spectrophotometer 83 served as the primary standard instrument at the comparisons. (Subsequently, in 1980, instrument 83 was designated by the WMO as the World Primary Standard Dobson Spectrophotometer.) Participating foreign instruments were 41 (United Kingdom), 71 (former German Democratic Republic), 77 (Canada), 96 (Egypt), 105 (Australia), 108 (former USSR), 112 (India), and 116 (Japan). These 
foreign spectrophotometers were designated at that time by the WMO as secondary standard instruments, with the stipulation that they be used within their respective regions in future years for routine, periodic calibrations of field Dobson spectrophotometers.

(c) Since the mid-1970s, NOAA has not only periodically calibrated the secondary standard Dobson instruments named above, but has also been involved in a program to upgrade the quality of field Dobson instruments throughout the world. Numerous foreign instruments have been overhauled optically and electronically, and calibrated several times relative to Primary Standard Dobson Instrument 83. The work has been conducted in Boulder, Colorado, and at several WMO-sponsored Dobson instrument comparisons, e.g., in Aspendale, Australia, in 1980; in Arosa, Switzerland in 1990 and 1995; and in Tenerife, Canary Islands in 1994. All instruments in the global Dobson station network now have calibrations traceable either directly or indirectly to World Primary Standard Dobson Instrument 83. Since NOAA's involvement in the program, the quality of ozone data throughout the world has steadily improved. For example, at the Arosa Dobson Instrument Comparisons in 1990, of sixteen instruments calibrated relative to NOAA's standard instrument, twelve measured ozone amounts that agreed with the standard to $\pm 1 \%$. The other four instruments measured ozone values too low by $1.3-3.2 \%$.

(d) At the 1977 Boulder International Comparison of Dobson instruments [Komhyr et al., 1981] it was shown that well optically adjusted Dobson spectrophotometers could be calibrated to $\pm 1 \%$ with standard lamps calibrated with Dobson instrument 83. Conversely, the standard lamps could be used to identify field Dobson instruments that needed recalibration. To assess the status of instruments throughout the world, seven standard lamp units, each consisting of two calibrated lamps and a stable power supply, were built in 1981. The global Dobson instrument network was then divided into seven areas, each containing from 5-17 instruments, and a lamp unit was sent to each area to check on the calibration status of the instruments there. Results of calibration checks performed in 1981-1983 on 78 instruments [Grass and Komhyr, 1985] showed that 27 of these exhibited errors exceeding $2 \%$, with a number of instruments having errors of 6-10\%. During a repeat calibration check in 19851987 [Grass and Komhyr, 1989], of 81 instruments checked, errors larger than $2 \%$ were obtained only for 13 instruments, with the largest error being $4.6 \%$.

(e) The extensive Dobson instrument work performed by NOAA throughout the years has been of significant benefit to satellite ozone observing programs. As early as November 1986, Fleig et al. [1986] noted that there was a long-term drift between the SBUVITOMS total ozone and average total ozone measured from an ensemble of 42 Dobson instrument stations. It was not until 1988, however, when TOMS overpass total ozone data at Mauna Loa Observatory and Dobson instrument 83 calibration data for the years 1979, 1980, 1981, 1986, and 1987 
were inter-compared that the TOMS and SBUV instrument calibrations were shown conclusively to have drifted due to degradation of a diffuser plate shared by both instruments [McPeters and Komhyr, 1991]. Comparison results showed that relative to Dobson instrument 83 ozone values the TOMS instrument calibration drifted non-linearly downward by $7 \%$ during $1979-1989$. The calibration drift for the SBUV instrument was similar. TOMS satellite total ozone data that were presented in the 1988 WMO Ozone Trends Panel Report [1988] were normalized to data from the Dobson instrument network, and therefore to the calibration record of Dobson instrument 83 . The integrity of the conclusions concerning any trends in total ozone drawn by the Ozone Trends Panel depended critically on the calibration and maintenance record of Dobson instrument 83 . Currently satellite ozone observations rely heavily on ground truth from World Primary Standard Dobson Spectrophotometer 83 and the Dobson instrument network as a whole. The need for continued high quality Dobson instrument observations is now fully recognized.

The NOAA Dobson spectrophotometer total ozone data record is shown in Table 1. It is comprised of over 430 station-years of data from 28 stations, 16 of which (as indicated earlier) are currently in operation. All of the data have now been re-evaluated. Specific stations' data re-evaluated under D.O.E. Interagency Agreement No. DE-A103-93E1261726 are indicated in Table 1.

\subsection{Umkehr Observations}

NOAA Umkehr observations began in Boulder in 1978 with a manually operated Dobson spectrophotometer. In the early 1980 s a project was undertaken to automate Dobson spectrophotometer 61 for Umkehr observations. The work was accomplished successfully, and automatic Umkehr observations began in Boulder with instrument 61 in 1982. On the basis of the success of the instrument automation effort, funding was then sought to automate 6 additional Dobson instruments for establishment of a 7-station Umkehr observations network at select locations on earth for the purpose of early detection of stratospheric change. Funding for the project was secured from the U.S.A. Environmental Protection Agency (EPA), with contributions from the Chemical Manufacturers Association, Incorporated, and from NOAA. The 6 additional instruments were automated [Komhyr et al., 1984] and deployed in the mid 1980 s to two U.S.A. field sites (Mauna Loa Observatory, Hawaii, and Poker Flat, Alaska), and four foreign locations (Haute Provence, France; Huancayo, Peru; Lauder, New Zealand; and Perth, Australia).

The NOAA Dobson spectrophotometer Umkehr observations record is shown in Table 2. Considerable work has been accomplished in re-evaluating the Umkehr data through 1992. First processing of the 1993 and later data is also underway. 
Table 1. NOAA Dobson Spectrophotometer Total Ozone Data Record

\begin{tabular}{|c|c|}
\hline Station & Period of Record \\
\hline $\begin{array}{l}\text { Albuquerque, NM } \\
\text { American Samoa, South Pacific } \\
{ }^{2} \\
\text { Bedford, MA } \\
\text { Bismarck, ND } \\
\text { Boulder, CO } \\
\text { Byrd, Antarctica } \\
\text { Canton Island, South Pacific } \\
\text { Caribou, ME } \\
\text { Fairbanks, AK } \\
\\
\text { Fresno, CA }{ }^{2} \\
\text { Greenbay, WI } \\
\text { Hallett, Antarctica } \\
\text { Hanford, CA } \\
\text { Haute Provence, France }{ }^{1} \\
\text { Huancayo, Peru } \\
\text { Lauder, New Zeland }^{1} \\
\text { Mauna Loa, HI } \\
\text { Midland, Texass } \\
\text { Nashville, TN }{ }^{2} \\
\text { Perth, Australia }{ }^{1} \\
\text { Point Barrow, AK } \\
\text { Poker Flat, AK }{ }^{1} \\
\text { Puerto Montt, Chile }{ }^{1} \\
\text { South Pole, Antarctica }{ }^{1} \\
\text { Sterling, VA } \\
\text { Tallahassee, FL } \\
\text { Wallops Island, VA }{ }^{2} \\
\text { White Sands, NM }\end{array}$ & $\begin{array}{l}\text { February } 1965 \text { - July } 1966 \\
\text { December } 1975 \text { - present } \\
\text { October } 1963 \text { - December, } 1970 \\
\text { January } 1963 \text { - present } \\
\text { September } 1966 \text { - present } \\
\text { September } 1962 \text { - October } 1969 \\
\text { February } 1965 \text { - July } 1966 \\
\text { January } 1963 \text { - present } \\
\text { December } 1964 \text { - June } 1972 \\
\text { February } 1993 \text {-present } \\
\text { June } 1983 \text { - March } 1995 \\
\text { January } 1963 \text { - June } 1975 \\
\text { January } 1962 \text { - October } 1962 \\
\text { March } 1995 \text { - present } \\
\text { September } 1983 \text { - present } \\
\text { February } 1964 \text { - December } 1992 \\
\text { January } 1987 \text { - present } \\
\text { January } 1964 \text { - present } \\
\text { July } 1962 \text { - Ociober } 1963 \\
\text { January } 1963 \text { - present } \\
\text { July } 1984 \text { - present } \\
\text { August } 1973 \text { - December, } 1982 ; \\
\text { June } 1986 \text { - present } \\
\text { March } 1984 \text { - May } 1992 \\
\text { November } 1964 \text { - December } 1965 \\
\text { November } 1961 \text { - present } \\
\text { January } 1962 \text { - June } 1967 \\
\text { May } 1964 \text { - November } 1989 \\
\text { April } 1993 \text { - present } \\
\text { July } 1967 \text { - present } \\
\text { January } 1972 \text { - January } 1982\end{array}$ \\
\hline
\end{tabular}

${ }^{1}$ Stations for which total ozone data were re-evaluated under D.O.E. Interagency Agreement DE-A103-93E1261726.

${ }^{2}$ Stations for which data re-evaluation was updated through December 31, 1994. 
Table 2. Umkehr Observations Data Record

\begin{tabular}{llc}
\hline Station & Period of Record & No. Obs.* \\
\hline Boulder, CO & February 1978 - present & 1675 \\
Fairbanks, AK & February 1993 - present & - \\
Haute Provence, France & August 1983 - present & 1908 \\
Huancayo, Peru & April 1985 - December 1991 & 40 \\
Lauder, New Zealand & February 1987 - present & 653 \\
Mauna Loa, HI & October 1983 - present & 2557 \\
Perth, Australia & June 1984 - present & 1906 \\
Poker Flat, AK & March 1984 - May 1992 & 607 \\
\hline
\end{tabular}

*Number of Umkehr observations made through December 1991.

While few problems were experienced at the majority of the Umkehr. stations throughout the years, the program at Huancayo was largely unsuccessful because the station infrastructure there was unable to adequately support operation of a fairly sophisticated automated Dobson instrument. Furthermore, station operations were at times adversely affected by subversive actions of the Peruvian Shining Path Guerrillas.

Due to a decrease in staffing at the Poker Flat facility in 1992, the Umkehr observations program was relocated to nearby Fairbanks, Alaska, in the winter of 1992-1993.

\section{Total Ozone Data Re-evaluation}

Provisional total ozone data from the NOAA Dobson spectrophotometer station network have been routinely archived throughout the years at the WMO World Ozone Data Center (WODC) in Downsview, Ontario, Canada, generally within 2-3 months after acquisition of the data. The provisional nature of the data stemmed from the need for final instrument calibrations that were performed several or more years after initial calibrations. Additionally, standard empiricallyderived charts used for determining ozone values from observations on the zenith sky, or charts derived from sparse sets of comparison direct sun and zenith sky observations, did not always yield optimum quality data. Approximate corrections to the provisional data, determined from periodic re-calibrations of the field instruments, have been provided throughout the years to the WMO and to other users of the data upon request. These mean corrections, expressed as percent errors in measured ozone for an ozone amount of 300 Dobson units (DU) and an air mass of 2, have been applied linearly to back ozone data requiring correction. 
Because of the need for "ground truth" validation of satellite instrument ozone data and the desirability of obtaining reliable information on ozone trends during past decades, the NOAA National Environmental Satellite, Data, and Information Service (NESDIS), in cooperation with the WMO, embarked in 1991 on an international project to promote optimization of the quality of total ozone data from the global Dobson spectrophotometer station network. Following several meetings of experts, a "Dobson Data Re-Evaluation Handbook" was prepared [R.D. Hudson and W.G. Planet, eds.,1993; also available as WMO Global Ozone Research and Monitoring Project Report No. 29] which provided detailed instructions concerning total ozone data re-evaluation procedures. Ozone researchers throughout the world were then encouraged to re-evaluate their total ozone data records in accordance with procedures outlined in the Handbook.

\subsection{Total Ozone Data Re-evaluation Handbook}

The Dobson Data Re-evaluation Handbook (hereafter referred to as the Handbook) provides detailed information for data re-evaluation in three sections. Section I, prepared by K. Vanicek, is entitled "Examination of Instrument Histories". It describes historical information and data to be archived for each instrument. These include information about instrument ownership, places and periods of operation, organizations and persons in charge, raw data bases, past data processing and archiving, instrument calibrations (e.g., by the Langley plot method, with calibrated standard lamps, or relative to calibrated standard spectrophotometers), instrument optical wedge calibration data, instrument wavelength setting calibration data, monthly standard lamp and mercury lamp test data, and empirical charts or polynomials used in processing zenith sky observations.

Section II of the Handbook, prepared by W.D. Komhyr and entitled "Evaluation of Instrument Constants", provides detailed instructions for reevaluating total ozone data obtained with spectrophotometers that have calibrations traceable to World Primary Standard Dobson Instrument 83 (or to Secondary Standard Instrument 65). These include all NOAA Dobson spectrophotometers operating since the early 1960 s as well as numerous other instruments of the global Dobson spectrophotometer network that have been periodically calibrated directly or indirectly relative to Dobson instrument 83 since the mid 1970s. Included in Section II, reproduced in Appendix A of this report, are updated calibration scales dating back to 1962 for primary and secondary standard Dobson spectrophotometers 83 and 65 . Instructions provided in the section for data re-evaluation are based on analyses of periodic initial and final calibrations of field instruments with the standard spectrophotometers to determine field instrument calibration changes that may have occurred with time. Changes in calibration may arise from accumulation of dust on the instrument optics, aging of the optics (particularly the mirrors), 
corrosion of cobalt filters by water vapor within instruments that were not always kept dry at field stations, occasional shifts in the alignment of the instrument optical components due to accidental jarring of the instrument, inadvertent use of imprecise wavelength settings during observations, and changes in the spectral characteristics of the instrument's optical wedge due to deterioration with time of the Canada balsam cement used in the wedges as a binder. Resulting calibration errors may be categorized into three classes: 1) those for which needed corrections are constants to be applied to the instrument's calibration parameters (N Tables); 2 ) those for which needed corrections are air mass ( $\mu$ ) dependent and instrument optical wedge characteristics remained stable with time; and 3), those for which needed corrections are air mass dependent but instrument optical wedge characteristics changed with time. Methods for correcting total ozone data for the three classes of errors are described in detail with examples in subsections $2.3,2.4$, and 2.5 , respectively, of Section II of the Handbook (see Appendix A). They will hereafter be referred to as data revaluation methods 2.3 (standard), 2.4 ( $\mu$-dependent), and 2.5 ( $\mu$-wedgedependent). Included in Section II, also, are instructions for deriving polynomial corrections to empirical charts that are used in deducing total ozone amounts from observation on clear and cloudy zenith sky.

Section III of the Handbook, prepared by R.D. Bojkov and A. Lapworth, describes procedures to be used in improving total ozone data obtained with instruments for which calibration data are unreliable or unavailable. Several methods may be used. First, the data should be examined for internal consistency (i.e., for obvious shifts in the data). Here, however, care must be taken to distinguish instrumentally induced data anomalies from those that may have been meteorologically induced. Second, because a high correlation exists between total ozone and $100 \mathrm{hPa}$ stratospheric temperatures, particularly at latitudes greater than $30^{\circ}$ away from the equator, useful information regarding ozone data quality can be obtained from correlation studies of the two variables. The correlation breaks down at high latitudes, particularly in Antarctica during the austral spring when considerable photochemical ozone destruction occurs. Finally, assessments of total ozone data quality can be made from comparisons of observations made at two nearby stations (e.g., in Europe where station density is relatively high), or in recent years from Dobson and satellite instrument data comparisons.

\subsection{NOAACMDL Re-evaluated Total Ozone Data Archive}

Because NOAA total ozone data have been obtained since the early 1960 s with field Dobson spectrophotometers calibrated throughout the years relative to World Primary Standard Dobson Instrument 83 , it has been possible to use instructions contained in Section II of the Dobson Data Re-evaluation Handbook exclusively in re-evaluating the data. There has been no need in the 
re-evaluations to resort to comparisons of the NOAA data with data from other sources (e.g., Brewer spectrometer data, or TOMS or SBUVISBUV-2 satellite data). The re-evaluated data, therefore, constitute a completely independent data set. All data have been re-evaluated using Bass and Paur [1985] ozone absorption coefficients, modified for use with Dobson ozone spectrophotometers [Komhyr et al., 1993].

Data re-evaluation for each of the 28 stations where observations have been made is fully documented in a set of hard copy volumes stored at the NOAA CMDL laboratory in Boulder, Colorado. (The same information is available also on computer hard disk.) Information contained in each set of volumes is the following:

\section{Basic Information:}

(a) Station name, latitude, longitude, elevation, Greenwich mean time minus local standard time, mean atmospheric pressure, mean height of the ozone layer at the station, and earth radius at the station.

(b) List of Dobson instruments used at the station and their periods of operation.

(c) Equations used in deducing ozone from direct sun and moon observations made on various wavelengths; including ozone absorption and scattering coefficients.

\section{Monthly Lamp Tests Data:}

(a) Summary of mercury lamp tests data obtained routinely throughout the years at monthly intervals to ensure that observations are made on correct wavelengths. Included are Dobson instrument $Q$ (wavelength setting) tables used at the station. Sample data are shown in Appendix B.

(b) Summary of standard lamp tests data obtained at the station at monthly intervals to check on Dobson instrument calibration stability. Included are Reference Standard Lamp Readings established at times of instrument recalibrations. Sample data are shown in Appendix B.

\section{Wedge Calibration Data}

(a) These are results of instrument optical wedge calibrations made every several years as a check on the stability of the optical wedge. The data can be used to correct initially-derived ozone values for time intervals when a significant change occurred in the spectral characteristics of the wedge. Sample archived optical wedge calibration data are shown in Appendix C. 
Instrument Historical Information

(a) In conjunction with calibration data presented for the instrument applicable to the time of initiation of observations at a station, a brief past history of the instrument is given which includes information about instrument ownership, past operations (including past calibration data if available), and modifications made to the instrument which may include optical realignment and electronic modernization.

(b) In conjunction with subsequent presentations of instrument re-calibration data in the archive volumes, the documentation of the instrument histories is continued, summarizing problems that may have occurred with the instrument since its previous calibration, solutions to the problems, optical wedge and wavelength-setting re-calibrations, etc. More detailed such information is preserved in a separate archive at NOAACMDL in Boulder, Colorado.

\section{Instrument Calibration Records}

(a) NOAA field Dobson spectrophotometers have been calibrated with Primary Standard Dobson Instrument 83, or with Secondary Standard Instrument 65 since 1962. (On rare occasions calibrations were affected by means of standard lamps calibrated with instrument 83 .) The calibrations are conducted by making simultaneous ozone observations on direct sunlight with the two instruments during one-half day (i.e., over a $\mu$ range of about 1-5), analyzing the observational data, then transferring the calibration constants of the standard instrument to the field instrument. The majority of the instrument calibrations have been conducted throughout the years in pairs, i.e., an 'initial' calibration followed several years later by a 'final' calibration performed on the instrument in an "as is" condition. It is from the 'final' calibration that calibration corrections are derived. The NOAACMDL data archive volumes contain all instrument calibration records. These include raw calibration data, data analyses, and final results. Sample 'initial' instrument calibration data are shown in Appendix D. Sample 'final' calibration records used in re-evaluating data by the standard, $\mu$ dependent, and $\mu$-wedge-dependent methods, also provided in the archive volumes, are shown in sections 2.3, 2.4, and 2.5 of Handbook Section II (Appendix A).

\section{Corrections to Zenith Sky Observations}

(a) Zenith sky observational total ozone data are reduced in the NOAA program using standard empirical charts derived in the past from quasi-simultaneous observations on direct sun and the clear and cloudy zenith [Komhyr, 1980]. Because the chart characteristics are ozone vertical distribution and instrument dependent, it is necessary to determine needed corrections to the charts for each station. This is accomplished through analyses of additional comparison 
direct sun and zenith observational data obtained at the station. All such analyses, as well as the deduced corrections ( $\mu$-dependent polynomials), are documented in the data archive volumes. Sample analyses and deduced corrections are shown in Appendix A.

(b) This section of the data archive volumes also contains edited standard lamp tests data. These edited data, together with corrected instrument calibrations, are used in processing the direct sun observations with which zenith sky observations are compared.

(c) Since direct sun observations on AD wavelengths are fundamental, analyses are performed also on quasi-simultaneously made $A D$ and $C D$ wavelength direct sun observations to determine correction factors that reduce the $C D$ wavelength observations to the $A D$ level. $C D$-wavelength direct sun observations are made in the $\mu$-range 2.5-5.0.

\section{Re-evaluated Total ozone Data}

(a) Re-evaluated total ozone data are presented in the data archive volumes month-by-month. Included are the basic parameters that were used in processing the data (e.g., station latitude, longitude, time zone, mean height of the ozone layer, etc.) as well as the ozone absorption and scattering coefficients employed. These are followed by a listing of the instruments used and their periods of operation, calibration scales employed in the data processing, polynomial coefficients used in processing the data to optimize the quality of ozone values derived from zenith sky observations, and the CD direct sun observations' correction factors. A sample of such data is shown in Appendix $E$.

(b) Archived data for a month (a sample of which is also shown in Appendix $E$, consists of all observations made during the month. Information archived for each observation includes the date and time of the observation, the raw observational data, the kind of observation made (wavelengths employed; whether made on direct sun, moon, or zenith sky), coded sky condition information, mean airmass $(\mu)$ value for the observation, standard lamp corrections applied in processing the data, and finally the computed ozone value expressed in atmo-cm ozone. From the available data, up to five representative total ozone values obtained at different times of the day are selected to comprise the re-evaluated ozone data base. A single ozone value is then chosen for each day to be representative of the total ozone present over the station at local apparent noon. The ensemble of these values comprises the NOAACMDL archive of daily total ozone values, which are also archived at the WODC in Downsview, Ontario, Canada. 


\subsection{Brief Observing Program Histories}

\subsubsection{Amundsen-Scott, Antarctica}

Total ozone observations began at Amundsen-Scott, Antarctica $\left(90.0^{\circ} \mathrm{S}\right.$, $24.8^{\circ} \mathrm{W}$ ), with Dobson spectrophotometer 65 on September 17, 1961, and continued with instrument 65 through November 28, 1963. The observing program at the site was implemented by the Polar Operations Project of the U.S. Weather Bureau prior to the time that $W$. Komhyr assumed responsibility for the U.S.A. Dobson instrument program operations in late 1961. The 1961 calibration of instrument 65 was based on an original calibration performed in the late 1950s or 1960-1961 at Oxford, England, by R and J Beck, Limited, the manufacturer of the instrument. Relevant calibration tables and constants have not been located.

In December 1962, Dobson spectrophotometer 82, which had been optically, electronically, and mechanically overhauled in Boulder earlier and calibrated with primary standard Dobson instrument 83 on September 14, 1962, was transported to Amundsen-Scott station where comparison ozone observations were made with instruments 65 and 82 during December 17-22, 1962. Instrument 82 was then shipped to Hallett, Antarctica, where it was in operation through October 1963 at which time the Hallett ozone observing program was discontinued. Instrument 82 was then returned to Amundsen-Scott station where ozone observations with it began December 5, 1963.

In subsequent years, total ozone observations at Amundsen-Scott station were made alternately with Dobson instruments 80 and 82 . Instrument calibrations were conducted throughout the years according to the schedule shown in the table below. The column in the table named 'Initial' Calibrations lists the times of primary calibrations of instruments 80 and 82, while the 'Final' Calibrations column lists the calibrations from which needed data corrections are deduced. The designators $R$ (and $M$ or $U$, and $W$, not indicated in the above calibration scales but which occur for other instruments) denote the method

\begin{tabular}{llll}
\hline \multicolumn{1}{c}{ 'Initial' Calibrations } & Ref. Inst. & 'Final' Calibrations & Ref. Inst. \\
\hline \#65 Unavailable, 1961 & R/J Beck & $\# 65$ Dec. 17-22, 1962 & $\# 82 / 83$ \\
$\# 82$ Sept. 14, 1962 R1 & $\# 83$ & $\# 82$ Oct. 29, 1973 & $\# 83$ \\
$\# 80$ Aug. 7, 1972 R1 & $\# 83$ & $\# 80$ Nov., 1978 & Lamp X \\
& & $\# 80$ May 1, 1986 & $\# 83$ \\
$\# 82$ Aug. 6, 1985 R1 & $\# 83$ & $\# 82$ May 21, 1990 & $\# 83$ \\
$\# 80$ May 26, 1988 R1 & $\# 83$ & $\# 80$ April 30. 1993 & $\# 83$ \\
& & $\# 80$ Oct. 11. 1994 & $\# 83$ \\
$\# 82$ Aug. 27, 1992 R1 & $\# 65$ & & \\
\hline
\end{tabular}


employed in data re-evaluation, whether standard, $\mu$-dependent, or $\mu$-wedgedependent. No significant instrument calibration changes occurred at Amundsen-Scott station. Changes in instrument optical wedge densities were minor. Thus, re-evaluation of the total ozone data was performed according to Handbook method 2.3 (i.e., the non- $\mu$-wedge-dependent method).

Due to observer error, total ozone observations were made incorrectly at Amundsen-Scott station with Dobson instrument 80 during October and November of 1983. The problem stemmed from operation of the instrument with its wavelength selector rod in the 'long' rather than the 'short' position when direct sun observations were made on $A D$ and $C D$ wavelengths. This caused observations to be made on the long, but not the short, wavelength of each wavelength pair $A, C$, or $D$, as well as on other near-visible wavelengths. Fortuitously, computed ozone amounts fell within the range of values observed in past years at Amundsen-Scott station. Following recognition of the observing problem, corrections to the October 1993 Amundsen-Scott station total ozone data were deduced in Boulder from quasi-simultaneous observations made correctly and incorrectly (as at Amundsen-Scott) in Boulder with Dobson instrument 80 . Corrected October 1983 ozone values for Amundsen-Scott were considerably lower than values originally deduced.

\subsubsection{Byrd, Antarctica}

Dobson instrument 80 was shipped to Byrd, Antarctica $\left(80.0^{\circ} \mathrm{S}, 119.5^{\circ} \mathrm{W}\right)$, by the Polar Operations Project Group of the U.S.A. Weather Bureau for total ozone observations probably in 1961. At that time only a tentative calibration was assigned to the instrument. First observations were made at Byrd in August 1962.

W. Komhyr traveled to Byrd in November 1963. At that time the optics and electronics of instrument 80 were checked and corrected where necessary, the optical wedge was calibrated by the two lamp method, and wavelength settings were established by means of discharge lamp tests. The instrument was then calibrated on November 17, 1963, with traveling standard lamps $X$ and $Y$ that had been calibrated with primary standard Dobson instrument 83.

\begin{tabular}{|c|c|c|c|}
\hline 'Initial' Calibrations & Ref. Inst. & 'Final' Calibrations & Ref. Inst. \\
\hline$\# 80$ Nov. $17,1963 \mathrm{~W}_{\mathbf{i}}$ & $X, Y$ & $\begin{array}{l}\# 80 \text { Nov. } 30,1968 W 1_{f} \\
\# 80 \text { Aug. } 7,1972^{* \#}\end{array}$ & $\begin{array}{l}X, Y^{*} \\
\# 83\end{array}$ \\
\hline
\end{tabular}

- Initial calibration, with routine standard lamp test corrections applied.

* Approximate instrument 80 calibration check made after optical adjustment and repair of instrument. 
Total ozone observations continued at Byrd uneventfully through about November 1968. In December 1968, (or early in 1969), something happened to the instrument causing its spectral characteristics to change drastically. Although observations continued to be made in 1969, the data could not be processed reliably.

Final processing of the Byrd total ozone data was based on the November 17,1963 calibration of Dobson instrument 80 , taking into account small instrument spectral characteristics changes as determined from monthly standard lamp tests made at the station, as well as a minor change in the instrument's optical wedge densities that occurred during 1963-1968. An intercalibration of instrument 80 with primary standard Dobson spectrophotometer 83 in Boulder in 1972, made after optical realignment of the instrument and a cobalt filter change, suggested that monthly mean ozone measurement errors in the reevaluated Byrd data most likely fell within the range of 0 to -1.5 percent.

\subsubsection{Fairbanks, Alaska}

NOAA (then the U.S. Weather Bureau) total ozone observations first began at Fairbanks, Alaska $\left(64.8^{\circ} \mathrm{N}, 147.9^{\circ} \mathrm{W}\right)$, in February 1965 , and continued through June 1972. Dobson spectrophotometer 76 used at the station was mechanically, optically, and electronically overhauled during August-September 1964 , and calibrated relative to primary standard Dobson instrument 83 on

\begin{tabular}{cccc}
\hline 'Initial' Calibrations & Ref. Inst. & 'Final' Calibrations & Ref. Inst. \\
\hline$\# 76$ Oct. 16, 1964 R1 & $\# 83$ & \#76 Aug. 9, 1972 & $\# 83$ \\
$\# 63$ May 29, 1992 R1 & $\# 83$ & & \\
\hdashline
\end{tabular}

October 16, 1964. A visit was made to Fairbanks in 1969 to effect minor instrument repairs, perform calibration checks and clean the instrument optics. Following termination of operations at Fairbanks in 1972, the Dobson instrument was returned to Boulder. A recalibration of instrument 76 relative to Dobson instrument 83 was made on August 9,1972, indicating a calibration change of $1.5 \%$ for ozone amounts of $300 \mathrm{DU}$ and an air mass of 2 . During final data reevaluation performed according to standard Handbook method 2.3, this needed correction was applied linearly with time to the data for the period of observations. A small change occurred in the optical wedge densities of instrument 76 during 1964-1972. Had final data re-evaluation been performed using Handbook method 2.5 (i.e., the $\mu$-wedge-dependent method), the derived total ozone amounts would have differed by no more than about $\pm 1 \%$ from the values obtained. 
Total ozone observations were resumed at Fairbanks in February of 1993 with Dobson ozone spectrophotometer 63. This occurred following re-location of instrument 63 from nearby Poker Flat, Alaska, where it had been in operation during March 1984-May 1992.

\subsubsection{Hallett, Antarctica}

Observations of total ozone began at Hallett, Antarctica $\left(72.3^{\circ} \mathrm{S}, 170.2^{\circ} \mathrm{E}\right)$, with Dobson instrument 37 in January 1961. The instrument had been installed there by the Polar Operations Project Group of the Weather Bureau prior to the time that W. Komhyr assumed responsibility for the U.S.A. Dobson instrument program operations in late 1961. Calibration tables and constants used in processing the data were based on the original calibration of instrument 37 made at Oxford, England in 1960. Routine (monthly) instrument calibration checks (standard lamp and mercury lamp tests) were not made. Instrument 37 continued to be operated at Hallett through October, 1962. In November 1962, the instrument optical wedge bands broke, and the instrument was shipped to Boulder for repair. Because standard lamp tests had not been made at Hallett, it was impossible to reposition the optical wedge close to its original position upon repair. An intercalibration of instruments 37 and 83 was, therefore, not

\begin{tabular}{llll}
\hline 'Initial' Calibrations & Ref. Inst. & 'Final' Calibrations & Ref. Inst. \\
\hline \#37 Oct. 1, 1960 X0 & $\begin{array}{l}\text { R.J.Beck } \\
\text { \#82 Sept. 14, 1962 R1 }\end{array}$ & \\
\hline
\end{tabular}

performed in Boulder. The Hallett total ozone data, as archived, were therefore processed using the 1960 calibration of R.J. Beck, Ltd., and have no tie-in to the calibration scale of World Primary Standard Dobson Instrument 83.

In January 1963, Dobson instrument 82 was installed at Hallett. It had been calibrated in Boulder in September 1962 relative to Dobson instrument 83. Total ozone observations were made during February-October 1963. The observations were terminated at Hallett in November 1963 due to logistics considerations. Instrument $\mathbf{8 2}$ was then shipped to Amundsen-Scott, Antarctica, where it was put into operation on December 28, 1963.

\subsubsection{Haute Provence, France}

French Dobson instrument 85 was transported to Boulder in May 1983 to be automated for Umkehr observations. At that time new electronics and an "airspace" optical wedge were installed into the instrument, the optics were realigned, and wavelength-settings and optical wedge densities determined. An 
initial calibration of the instrument was performed on June 21,1983 , relative to World Primary Standard Dobson Instrument 83.

\begin{tabular}{cccc}
\hline 'Initial' Calibrations & Ref. Inst. & 'Final' Calibrations & Ref. Inst. \\
\hline$\# 85$ June 21, 1983 R1 & $\# 83$ & \#85 Aug. 21, 1986 & $\# 83$ \\
& & $\# 85$ Aug. 25, 1986 & $\# 83$ \\
& & $\# 85$ July 7, 1990 & $\# 65$ \\
\#85 July 10, 1990 R1 & $\# 65$ & $\# 85$ July 27, 1995 & $\# 65$ \\
& & $\# 85$ July 31, 1995 & $\# 65$ \\
\hline
\end{tabular}

A calibration check made on the instrument August 21, 1986, showed the instrument to be in good calibration. No calibration change was detected several days later following cleaning of the instrument, so that the \#85 June 21, 1983 R1 calibration scale of instrument 85 continued to be used. The calibration of instrument 85 was checked again on July 7,1990 . Only a small calibration change was detected $\left(-0.7 \% \mathrm{O}_{3}\right.$ error at $\mu=2$ and $\left.x=300 \mathrm{DU}\right)$. After cleaning the instrument optics, a new calibration scale for the instrument was established on July 10, 1990.

Checks on the \#85 July 10,1990 R1 calibration scale of Dobson instrument 85 were made at Arosa, Switzerland, on July 27 and 31, 1995. These indicated needed corrections to instrument 85 ozone values of less than $1 \%$ (for 300 DU ozone and $\mu \sim 2$ ). A decision was made, therefore to continue use of the \#85 July 10,1990 R1 calibration scale at Haute Provence following July 1995.

\subsubsection{Huancayo, Peru}

Total ozone observations began at Huancayo, Peru $\left(12.0^{\circ} \mathrm{S}, 75.3^{\circ} \mathrm{W}\right)$, with Dobson instrument 87 in February 1964. The instrument has not been used previously in an observing program. Prior to shipment to Peru, the optical alignment of the instrument was checked, the instrument's wavelength settings were established with discharge lamps, and its optical wedge was calibrated by the two lamp method. Instrument 87 was then calibrated with Primary Standard Dobson Instrument 83 on August 30, 1963.

Routine standard lamp tests performed at monthly intervals indicated stable instrument 87 performance during 1964 through about December 1, 1974 (i.e., lamp readings remained relatively constant), at which time the lamp readings began to decrease markedly with time. Re-calibration of the instrument with Dobson instrument 83 in February 1977 showed a large change in its calibration. An optical wedge calibration made February 19, 1977, revealed the 
main cause of the calibration change to have been a large change in the instrument's optical wedge densities.

A new calibration scale (\#87 Feb. 22, 1977 R1) was then established for instrument 87 . The instrument continued to be operated at Huancayo until early in 1983 when it was shipped to Boulder for automation for Umkehr observations. Recalibration of the instrument in Boulder on April 25, 1983, indicated a large calibration change again, accompanied by a substantial change in the optical wedge densities of instrument 87.

In the absence of Dobson instrument 87 , the continuity of observations at Huancayo was maintained with Dobson instrument 91 which had been shipped there for temporary use. Instrument 91 had been calibrated with primary standard Dobson instrument 83 in May of 1982. A recalibration of the instrument in March 1986 showed the instrument to be in excellent calibration.

Following automation of Dobson instrument 87 for Umkehr observations, at which time an 'air-space' optical wedge was installed into the instrument for optical stability, the instrument was recalibrated on May 15, 1985, and returned to Huancayo. Operations at Huancayo continued until termination of the ozone observing program there on December 31, 1992. A final calibration of instrument 87 was made in June 1994, indicating a relatively small calibration change, minor optical wedge density changes, but some air mass dependency in the observations.

In re-evaluating the Huancayo total ozone data, it was assumed that the 1974-1983 approximately parabolic downward drift in Dobson instrument 87

\begin{tabular}{lcll}
\hline 'Initial' Calibrations & Ref. Inst. & 'Final' Calibrations & Ref. Inst. \\
\hline \#87 Aug. 30, 1963 R1 & $\# 83$ & Std. Lamp Corr. Applied & $\# 87$ \\
$\# 87$ Dec. 1, 1974 W1 & $\# 87$ & $\# 87$ Feb. 15, 1977 W1 & $\# 83$ \\
$\# 87$ Feb. 22, 1977 W2 & $\# 83$ & $\# 87$ April 25, 1983 W2 & $\# 83$ \\
$\# 91$ May 18, 1982 R1 & $\# 83$ & $\# 91$ Oct. 8, 1985 & $\# 87$ \\
\#87 May 15, 1985 U1 $1_{\mathbf{i}}$ & $\# 83$ & $\# 81$ March 27, 1986 & $\# 83$ \\
\hline
\end{tabular}

routine standard lamp test readings was a reflection of the change that occurred in the instrument's optical wedge densities. Calibration scales used in reevaluating the data are shown in the table above. For the time intervals of high instrument stability, 1962-1974 and 1983-1985, the data were re-processed according to Handbook method 2.3. The assumed parabolic temporal change in optical wedge densities that occurred during 1974-1983 was approximated by 
two linear changes occurring during 1974-1977 and 1977-1983. Data reevaluations for these two time periods were performed using the $\mu$-wedge dependent Handbook method 2.5. Data obtained during 1985-1992 were reprocessed using the $\mu$-dependent Handbook method 2.4.

\subsubsection{Lauder, New Zealand}

The instrument in use at Lauder is U.S.A. instrument 72. (It had been operated at Wallops Island, Virginia, during 1967-1979.) In early 1983 instrument 72 was automated in Boulder for Umkehr observations. Prior to the automation, the instrument's electronics had been modernized, and its optical alignment checked. During the automation an "air-space" optical wedge was installed into the instrument to increase wedge stability.

The calibration record for Dobson spectrophotometer 72 is shown in the table below. The reference spectrophotometers used in calibrating instrument 72 are also listed in the table.

\begin{tabular}{lccc}
\hline 'Initial' Calibrations & Ref. Inst. & 'Final' Calibrations & Ref. Inst. \\
\hline$\# 72$ May 26, 1983 R1 & $\# 83$ & $\# 72$ June 28, 1985 & $\# 83$ \\
$\# 72$ May 1, 1986 R1 & $\# 83$ & $\# 72$ Dec. 13, 1988 & $\# 83$ \\
$\# 72$ Dec. 20, 1988 R1 & $\# 83$ & $\# 72$ July 14, i992 & $\# 65$ \\
$\# 72$ Nov. 14, 1991 R2 & $\# 65$ & & \\
$\# 72$ July 27, 1992 R2 & $\# 65$ & & \\
\hline
\end{tabular}

On November 14, 1991, the calibration of the Lauder Dobson instrument abruptly changed following inadvertent exposure of the instrument to rain. In July 1992, the instrument was transported to Boulder for recalibration. Calibration of the instrument on July 14, 1992, with it in an "as is" condition revealed a large change in the spectral characteristics of the optical wedge, particularly at $A$ wavelengths. The wedge was re-calibrated, and a new calibration scale, \#72 July 14, 1992 R2, was established for re-evaluation of ozone data obtained during November 14, 1991 to July 14, 1992. Cleaning of the wedge caused its spectral characteristics to revert to original values. A final calibration of the cleaned instrument was made July 27,1992 . The next calibration check is tentatively scheduled for early 1997.

\subsubsection{Perth, Australia}

Early historical records for U.S.A. Dobson instrument 81 are sparse. The instrument was apparently at Wilkes, Antarctica, in the early 1960s, from where it was loaned to Australia and set up for observations at Port Morsby, New 
Guinea in 1965. Later it was transferred to Danwin, Australia. During a 1976 hurricane at Darwin, the instrument was struck by a gas cylinder causing distortion of its R-dial shaft and damaging the optical wedge. The wedge was repaired by the Australians in 1977. In 1978 the instrument was relocated to Cairns, Australia. It was returned to Boulder in late 1983 at which time an "air space" optical wedge was installed into it (the wedge control R-dial shaft remained slightly bent); an old photomultiplier tube was replaced with a more sensitive new one, and the instrument optics were re-aligned. Following mechanical and electronic modification of the instrument for automatic Umkehr observations, the instrument's wavelength settings and optical wedge densities were established prior to calibrating the instrument and deploying it to Perth, Australia, for total ozone and Umkehr observations.

Times of calibration of Dobson instrument 81 are summarized in the table below. Following the 'initial' 1984 calibration, the instrument's steel band of the optical wedge broke in November, 1988. The wedge was repaired on site with

\begin{tabular}{lccc}
\hline 'Initial' Calibrations & Ref. Inst. & 'Final' Calibrations & Ref. Inst. \\
\hline \#81 May 8, 1984 R1 & $\# 83$ & $\# 81$ Nov. 18, 1988 & $\# 83$ \\
$\# 81$ Nov. 25, 1988 R1 & $\# 83$ & $\# 81$ June 19, 1992 & $\# 65$ \\
$\# 81$ July 7, 1992 R2 & $\# 65$ & & \\
\hline
\end{tabular}

care taken to reposition the wedge to its original configuration. That this was correctly done was verified by standard lamp tests and an instrument optical wedge calibration made November 22, 1988 . The November 25,1988 , calibration of Dobson instrument 81 was performed after cleaning and recalibrating the wedge on November 24. Prior to the instrument calibration of July 7, 1992, the wedge control R-dial shaft was straightened. The next calibration of instrument 81 is scheduled for early 1997.

\subsubsection{Poker Flat, Alaska}

Dobson instrument 63, which was in operation at Mauna Loa Observatory since the late 1950s, was brought to Boulder in 1983 for automation for Umkehr observations. The work included installation into the instrument of a new EMI photomultiplier tube and an "air-space" optical wedge, cleaning and re-alignment of the optics, and re-determination of instrument optical wedge densities and wavelength settings. Calibration of the instrument relative to World Primary Standard Dobson Instrument 83 was accomplished in May, 1983.

Ozone observations began at Poker Flat in March 1984. In March 1989, instrument 63 was returned to Boulder temporarily for a calibration check, and 


\begin{tabular}{llll}
\hline 'Initial' Calibrations & Ref. Inst. & 'Final' Calibrations & Ref. Inst. \\
\hline \#63 May 26, 1983 R1 & $\# 83$ & $\# 63$ March 24, 1989 & $\# 83$ \\
$\# 63$ May 29, 1992 R! & $\# 83$ & & \\
\hdashline
\end{tabular}

found to be in excellent calibration. Observations at Poker Flat continued into May 1992 when one of the steel bands of the optical wedge broke. In effecting repair, the wedge was repositioned as closely as possible to its original position within the instrument with the aid of standard lamp test data, but a subsequent calibration of the wedge showed a small change in optical wedge densities from original values. Recalibration of instrument 63 relative to Dobson instrument 83 in May 15, 1992, indicated a calibration change of nearly $1 \%$ since 1989. Because the change most likely resulted from the small shift in optical wedge densities, the \#63 May 26, 1983 R1 calibration scale of instrument 63 was used in final processing of the March 1989-May 1992 Poker Flat ozone data.

Following cleaning of Dobson instrument 63 optical components, a new calibration for the instrument relative to Dobson instrument 83 was obtained on May 27, 1992. Ozone observations at Poker Flat were, however, not resumed due to staffing problems at the site. Later in the year program operations were transferred to the Geophysical Institute of the University of Alaska in Fairbanks. Observations in Fairbanks began in February, 1993.

\subsubsection{Puerto Montt, Chile}

An 11-month total ozone measurements program was conducted at Puerto Montt, Chile $\left(41.5^{\circ} \mathrm{S}, 72.9^{\circ} \mathrm{W}\right)$, during November 1964-December 1965 in cooperation with the Chilean Meteorological service. Dobson instrument employed was No. 93. It had been obtained from the U.S. Air force in trade for a U.S. Weather Bureau Dobson instrument installed for total ozone measurements in 1963 at Bedford, Massachusetts. Prior to shipment to Chile, instrument 93

\begin{tabular}{cccc}
\hline 'Initial' Calibrations & Ref. Inst. & 'Final' Calibrations & Ref. Inst. \\
\hline$\# 93$ Oct. 16, 196400 & $\# 83$ & & \\
\hline
\end{tabular}

was thoroughly overhauled optically and electronically in Boulder, and calibrated relative to primary standard Dobson instrument 83 on October 16, 1964.

In December 1965 the instrument became inoperative, and could not be repaired on site. It was then put into storage and lost. After many attempts 
made to locate the instrument, it was finally found and returned to Boulder in 1978.

\subsubsection{U.S.A. Mainland Dobson Instrument Stations, Mauna Loa, Hawaii, and Samoa, South Pacific}

Considerable work was accomplished under D.O.E. Interagency Agreement No. DE-A103-93E1261726, also, in updating re-evaluations of total ozone data through the end of 1994 from six U.S.A. mainland stations (Caribou, Bismarck, Boulder, Wallops Island, Nashville, and Fresno), Mauna Loa Hawaii, and Samoa, South Pacific. In the past, data for most of the stations had been re-evaluated through about mid 1991. At the time of some of the earlier data reevaluations, computer programs for $\mu$ and $\mu$-wedge dependent data reprocessing were not yet finalized; to improve data quality the data were tentatively re-processed using standard Handbook method 2.3. Relevant portions of the records have since been re-processed by Handbook methods 2.4 and 2.5. Furthermore, re-evaluated data exhibiting apparent anomalies, particularly for Mauna Loa, Hawaii, have been submitted to special analyses such as, the processing of single pair wavelength data, to ensure optimal data quality. Brief operations histories for these stations, including calibration scales used in final data processing, will be presented in a more comprehensive version of this report that is being prepared for formal publication at a later date.

\section{Umkehr Data Re-evaluation}

Umkehr ozone observations, made at the NOAA stations with automated Dobson spectrophotometers, are comprised of series of morning or afternoon observations made on $A, C$, and D Dobson instrument wavelengths and the clear or sporadically cloudy zenith sky. In processing the data the instrument dial readings, converted to $\mathrm{N}$ values (related to measured wavelength relative intensities and the instrument's extraterrestrial constants), are plotted vs solar zenith angle. $N$ values extracted from the plots at solar zenith angles of 60,65 , $70,74,75,77,80,83,84,85,86.5,88,89$, and 90 degrees then serve as input data to computer algorithms from which ozone vertical distributions are deduced. Ozone profiles can be obtained from observations on $C$ wavelengths alone using the Standard Umkehr Evaluation Technique [Mateer and Dütsch, 1964], or a more current, improved version of the algorithm [Mateer and DeLuisi, 1991]. Ozone profiles can also be derived from "short" Umkehr observations made in the limited air mass range of 80-90 degrees [Deluisi, 1979], in which case observations on all three wavelengths $(A, C$, and $D)$ are needed.

Figure 1a is a plot of raw Umkehr data obtained from clear zenith sky, Cwavelength observations made at Mauna Loa Observatory on the morning of 

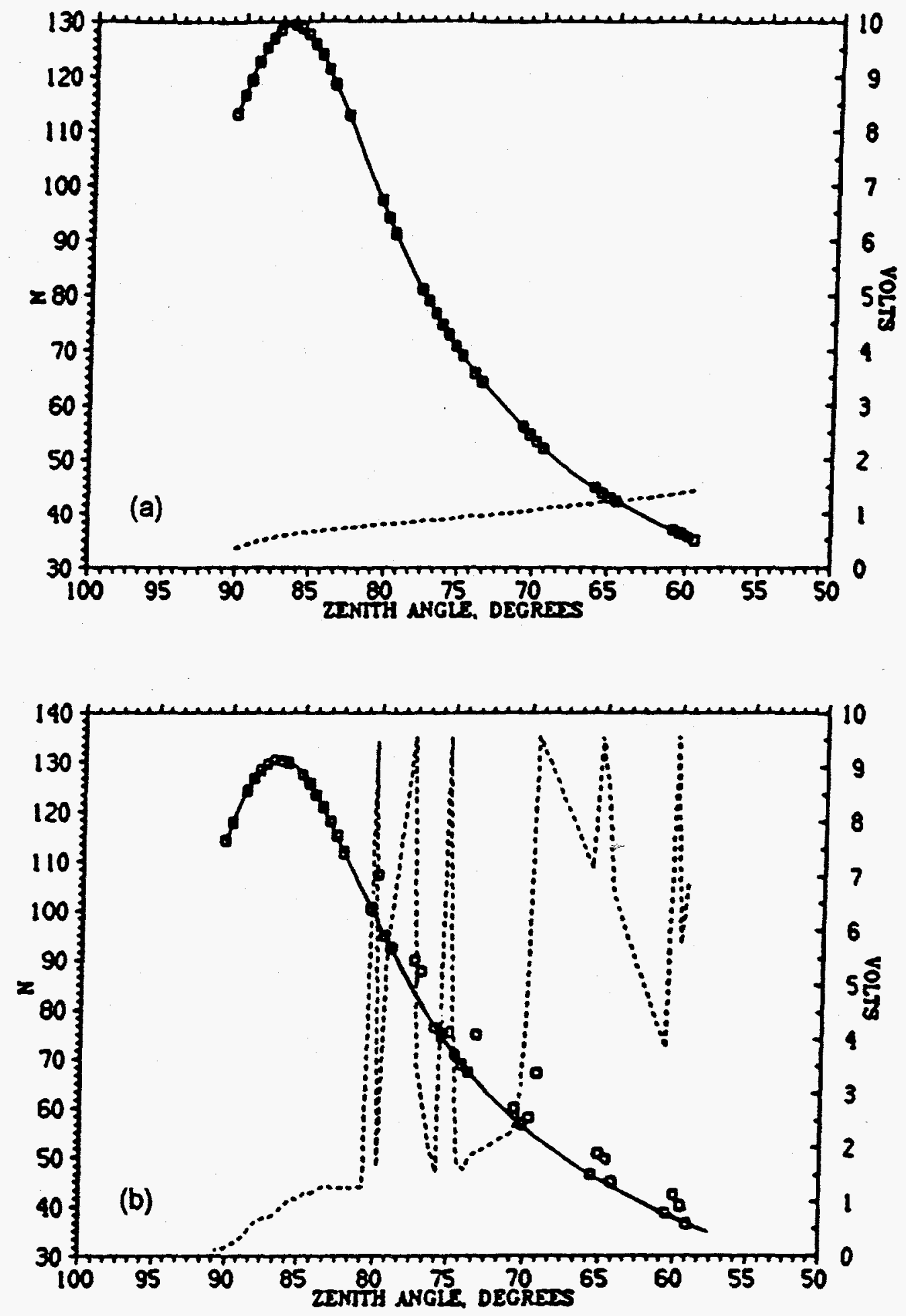

Figure 1. Umkehr observation $\mathbf{N}$ values vs solar zenith angles obtained at Mauna Loa Observatory from observations on C wavelengths and (a) clear and (b) cloudy zenith sky. 
March 21, 1988. All data points lie on a smooth least squares curve (cubic spline with fixed knots) that has been fitted to the data. Considerable scatter in the raw data is evident, however, for the Umkehr observation made March 19, 1988, when the zenith sky was at times cloudy (Figure 1b). To help identify erroneous data resulting from cloud interference, the NOAA Umkehr observatories were provided in 1988-1989 with sensitive photometric zenith cloud detectors [DeLuisi et al., 1988] that are operated whenever Umkehr observations are made. The dashed curves in the two figures are signals from such a detector. They are useful for assessing Umkehr data quality, and aid in the identification of erroneous observational data that are excluded from final Umkehr curve fitting routines.

A main cause underlying the need for re-evaluation of routinely processed Umkehr data stems from the requirement that the instrument optical wedges be highly accurately calibrated since errors in optical wedge densities adversely influence Umkehr curve shapes. Dobson spectrophotometers are manufactured with wedges that contain Canada balsam cement as a binder of wedge sections. Experience throughout the years has shown that the cement can deteriorate with time, causing large changes in the optical wedge characteristics. In automating the NOAA Dobson instruments for Umkehr observations, the Canada balsam cement was removed from all wedges. This has resulted in wedges whose spectral characteristics have remained virtually unchanged with time. Optical wedge characteristics can change, also, when contamination of the wedge occurs. This happened, for example at Lauder, New Zealand in 1991 when rain inadvertently entered the instrument. Although Umkehr observations were continued with the contaminated wedge for a one-half year thereafter, it was possible to re-evaluate the data following calibration of the contaminated wedge. Finally, optical wedge densities can change due to mechanical effects such as breaking of the wedge bands. Repair of the wedge on site generally restores it only approximately to its original configuration. Although Umkehr observations may continue to be made for many months, data obtained can be successfully re-evaluated following recalibration of the repaired wedge.

An important parameter of each Umkehr observation is the relevant total ozone, needed as input for the algorithm used in converting the raw data into ozone vertical distributions. The total ozone is measured during each one-half day when the solar elevation is near maximum for the day. Measurements at the NOAA automated Umkehr observatories are made by the station observers semi-automatically, generally on $A D$ (or $C D$ ) wavelengths and on direct sun. With observers not present on site, as for example on weekends or holidays, total ozone is derived from the observational zenith sky Umkehr data.

Incorporated into the re-evaluated Umkehr data are relevant re-evaluated total ozone data derived from the direct sun and zenith sky observations. 
Calibration data ( $\mathrm{N}$-tables) used in final re-evaluation of Umkehr data for Huancayo, Haute Provence, Lauder, Perth, and Poker Flat are identified in section 3 of this report. In Boulder, sporadic, manual Umkehr observations began in 1978 with Dobson instrument 82 . In 1981 Dobson instrument 61 was automated for Umkehr observations. An "air-space" optical wedge was installed into the instrument at the time, and the instrument was overhauled optically and electronically. Following calibration of the instrument in September 1981, a program of automated Umkehr observations began in Boulder in early 1982 that has continued into 1996. $\mathrm{N}$-tables used in re-evaluation of the Boulder data are shown below. The optical wedge densities of the instrument have been highly

\begin{tabular}{lclc}
\hline 'Initial' Calibrations & Ref. Inst. & 'Final' Calibrations & Ref. Inst. \\
\hline \#82 Aug. 31, 1977 R1 & $\# 83$ & $\# 82$ May 20, 1980 & $\# 83$ \\
$\# 82$ May 20, 1980 R1 & $\# 83$ & $\# 82$ Aug. 24, 1983 & $\# 83$ \\
$\# 38$ Sept. 21, 1978 R1 & $\# 83$ & $\# 38$ May 8, 1984 & $\# 83$ \\
$\# 61$ Sept. 8, 1981 R1 & $\# 83$ & $\# 61$ May 8, 1984 & $\# 83$ \\
$\# 61$ May 8, 1984 R1 & $\# 83$ & $\# 61$ April 11, 1985 & $\# 83$ \\
& & $\# 61$ Sept. 1, 1987 & $\# 83$ \\
$\# 61$ Sept. 1, 1987 R1 & $\# 83$ & $\# 61$ Aug. 14, 1991 & $\# 65$ \\
$\# 61$ Aug. 14, 1991 R1 & $\# 65$ & $\# 61$ Aug. 27, 1992 & $\# 65$ \\
$\# 61$ Aug. 27, 1992 R1 & $\# 65$ & $\# 61$ May 11, 1994 & $\# 83$ \\
$\# 61$ Aug. 8, 1994 R1 & $\# 65$ & & \\
\hline
\end{tabular}

stable throughout the years, with density changes between wedge calibrations generally corresponding to less than $0.01 \mathrm{~N}$

Umkehr observations began at MLO with automated Dobson instrument 76 on March 12, 1984. Earlier, in 1983, the instrument had been optically and electronically overhauled, an "air-space" optical wedge was installed into it, and optical wedge and wavelength setting calibrations performed. Instrument 76 was then calibrated with Primary Standard Instrument 83 on August 17, 1983. This calibration, as well as those made subsequently having suffixes $R 1, R 2$, and $X 8$, are listed in the table on the following page. Mu $(\mu)$ dependent $\mathrm{N}$-tables derived from these calibrations with suffixes such as $U 5_{i}$ and $M 7_{i}$, used in final reevaluation of the MLO total ozone and Umkehr data, are also shown in the table. (Handbook method 2.4 was resorted to in reprocessing of the MLO data because A-wavelength observations made with Dobson instrument 76 exhibited a $\mu$ dependency.)

When instrument 76 was first installed at MLO March 12, 1984, standard lamp readings were found to be in error by about $0.050 \mathrm{~N}$ unit. This was because a temperature sensor cable had accidentally become dislodged within 


\begin{tabular}{|c|c|c|c|}
\hline 'Initial' Calibrations & Ref. Inst. & 'Final' Calibrations & Ref. Inst. \\
\hline \#76 Aug. 17, 1983 R1 & \#83 & & \#83 \\
\hline \#76 Aug. 17, 1983 U5 & \#83 & $\begin{array}{l}\text { \#76 Nov. 24, } 1984 \text { U5 } \\
\text { \#76 May 14, } 1987 \text { R2 }\end{array}$ & $\begin{array}{l}\# 83 \\
\# 83\end{array}$ \\
\hline $\begin{array}{l}\text { \#76 Nov. 25, } 1984 \text { U5i } \\
\text { \#76 May 19, } 1987 \text { R1 }\end{array}$ & $\begin{array}{l}\# 83 \\
\# 83\end{array}$ & \#76 May 14, 1987 U5f & $\# 83$ \\
\hline \#76 May 19, 1987 U6 & $\# 83$ & $\begin{array}{l}\text { \#76 June 8, } 1991 \\
\text { \#76 June 8, } 1991 \text { U6 }\end{array}$ & $\begin{array}{l}\# 83 \\
\# 83\end{array}$ \\
\hline \#76 June 9, 1991 R1 & \#83 & & \\
\hline \#76 June 9, 1991 M7i & \#83 & $\begin{array}{l}\text { (Used June 9-July 18, } \\
\text { 1991, only) }\end{array}$ & \\
\hline \#76 Aug. 7, 1991 R1 & $\# 65$ & & \\
\hline \#76 Aug. 7, 1991 M8 & $\# 65$ & $\begin{array}{l}\text { (Used Aug. } 7,1991 \text {-June } \\
28,1992 \text {, only) }\end{array}$ & v \\
\hline \#76 June 28, 1992X8 & $\# 65$ & $\begin{array}{l}\text { (Used June } 28,1992-J u l y \\
15,1993 \text {, only) }\end{array}$ & \\
\hline \#76 June 16, 1993 R1 & \#83 & & \\
\hline \#76 June 16, $1993 \cup 9_{i}$ & \#83 & $\begin{array}{l}\text { (Used June 16, 1993- } \\
\text { Feb. 22, 1994, only) }\end{array}$ & \\
\hline $\begin{array}{l}\text { \#76 May 11, } 1994 \text { R1 } \\
\text { \#76 May 11, } 1994 \text { M9 }\end{array}$ & $\begin{array}{l}\# 83 \\
\# 83\end{array}$ & & \\
\hline
\end{tabular}

the instrument, falling into the instrument's light beam to partially obstruct it. Operation of the instrument was, however, continued "as is" until November 24, 1984 , when the problem was corrected and standard lamp readings reverted to normal values. On November 24 , also, a smudge observed on the instrument's optical wedge was cleaned off the wedge. Re-evaluation of the March 12November 24, 1984, MLO ozone data was based, therefore, on the August 17, 1983 R1 calibration of instrument 76, with standard lamp corrections applied.

When Dobson instrument 76 was next calibrated May 14, 1987, a change was noted in its optical wedge densities. This was assumed to have resulted from cleaning of the wedge in November 1984. The November 25, 1984-May 14,1987 MLO ozone data re-processing was, therefore, based on the May 14, 1987 R2 calibration of Dobson instrument 76 , with the processing performed backwards in time to 1994.

Calibration of Dobson instrument 76 on June 9, 1991, showed worsening of its A-wavelength $\mu$ dependency. A decision was therefore made in July to return the instrument to Boulder to correct the problem. While in Boulder during late July to early August, 1991, all quartz optical components were cleaned, sticky mirror M1 was repaired, scratched mirror M2 was replaced, and a 
corroded cobalt filter was re-polished. The instrument was then re-calibrated August 7,1991 , exhibiting considerably less A-wavelength $\mu$ dependency. Instrument 76 was then returned to MLO where observations began again on August 7, 1991.

Operation of the instrument 76 continued at MLO uneventfully until June 28,1992 when suddenly a problem surfaced, causing AD-wavelength total ozone observations to be too high by about $3 \%$. Subsequently, on June 16 , 1993, the problem was traced to a faulty spring that adversely affected the instrument's automatic balancing of the optical wedge when observations were being made on $D$ wavelengths. The wedge setting error was determined to be $0.010 N_{D}$ unit. The June 28, 1992-July 16, 1993 MLO ozone data were, therefore, re-processed using $\mathrm{N}$-tables \#76 June $28,1992 \times 8$, equivalent to the \#76 August 7, $1991 \mathrm{~N}$-tables, but with 0.010 unit added to $\mathrm{N}_{\mathrm{D}}$ values. The corrected data, when compared with observations made with Dobson instrument 83 at MLO during part of the time interval under consideration, were found to be satisfactory.

Following correction of instrument 76's mechanical problem, the instrument was re-calibrated on June 16, 1993. Ozone observations were then continued at MLO through February 22, 1994, when a band broke on the instrument's optical wedge. Repair of the wedge was made in Boulder, with recalibration of the instrument on April 12,1994. Shortly after return of instrument 76 to MLO the band on the optical wedge broke again. The instrument was once again returned to Boulder for repair, and re-calibration on May 11, 1994. (Because of problems with the optical wedge, ozone observations were not made at MLO during February 22-May 25, 1994.) Ozone observation at MLO have continued into 1996 without interruption since May 26, 1994.

\section{WODC Re-evaluated Total Ozone Data Archive}

As indicated earlier, total ozone data re-evaluated under D.O.E. Interagency Agreement DE-A103-93ER61726 included data not only from the 10 stations Amundsen Scott, Byrd, Fairbanks, Hallett, Huancayo, Haute Provence, Lauder, Perth, Poker Flat, and Puerto Montt, but also 1990s portions of records from Caribou, Bismarck, Boulder, Wallops Island, Nashville, Fresno, Mauna Loa Observatory and Samoa Observatory. These data from 18 stations, representing 327 station years of data and shown in Figures 2 and 3 as monthly means, will be submitted early in 1996 to the World Ozone Data Center (WODC) in Downsview, Ontario, Canada, for archiving.

Table 3 is a sample record of archived 1993 data from Boulder, Colorado. Listed in the extreme left hand column of the table are the station number, and the month and year of the observations. Total ozone data, together with auxiliary information, are recorded for each month in 8 columns of 4 lines each. 


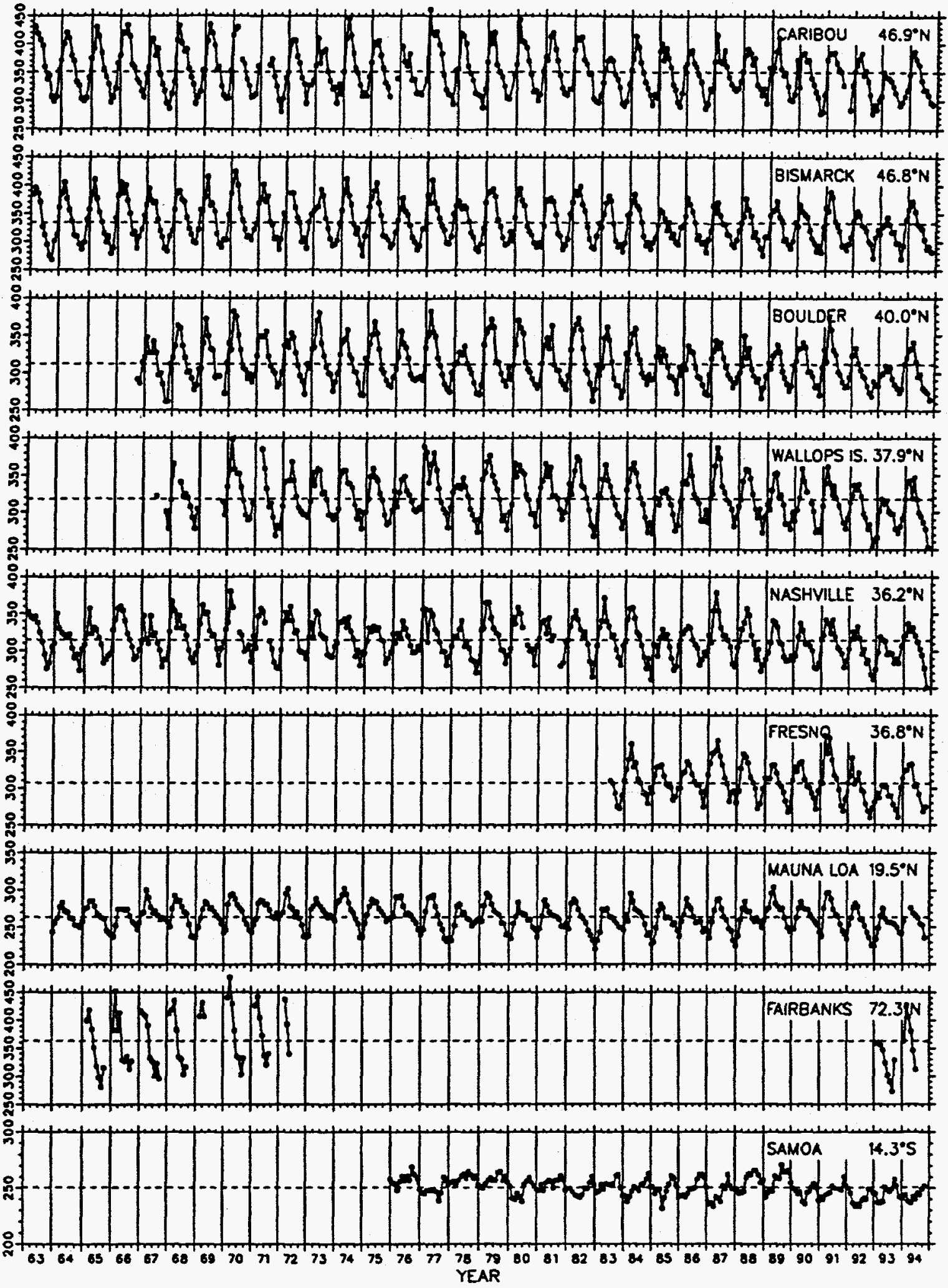

Figure 2. Total ozone monthly means from re-evaluated data, for stations indicated in the plots. 

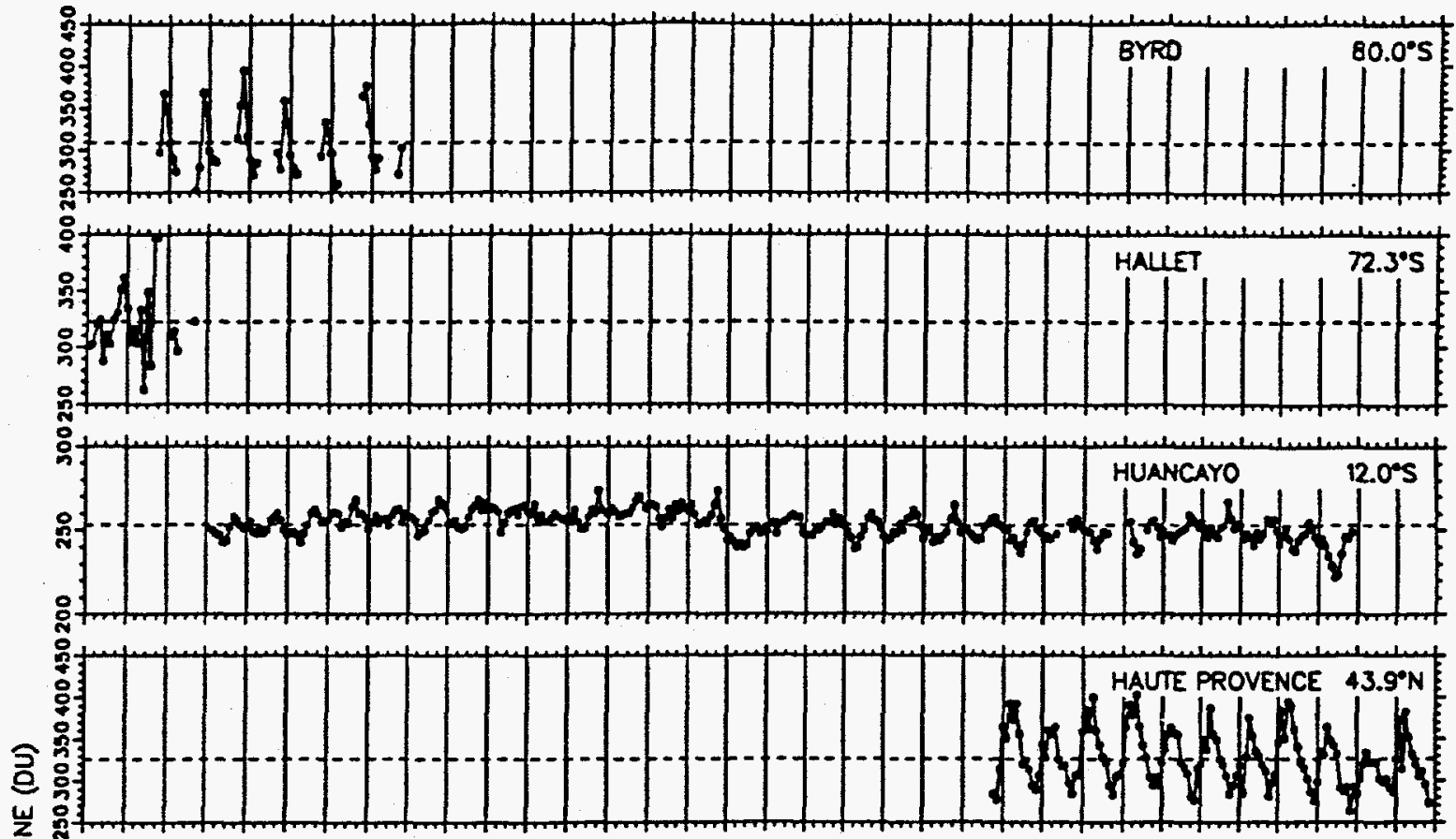

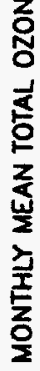

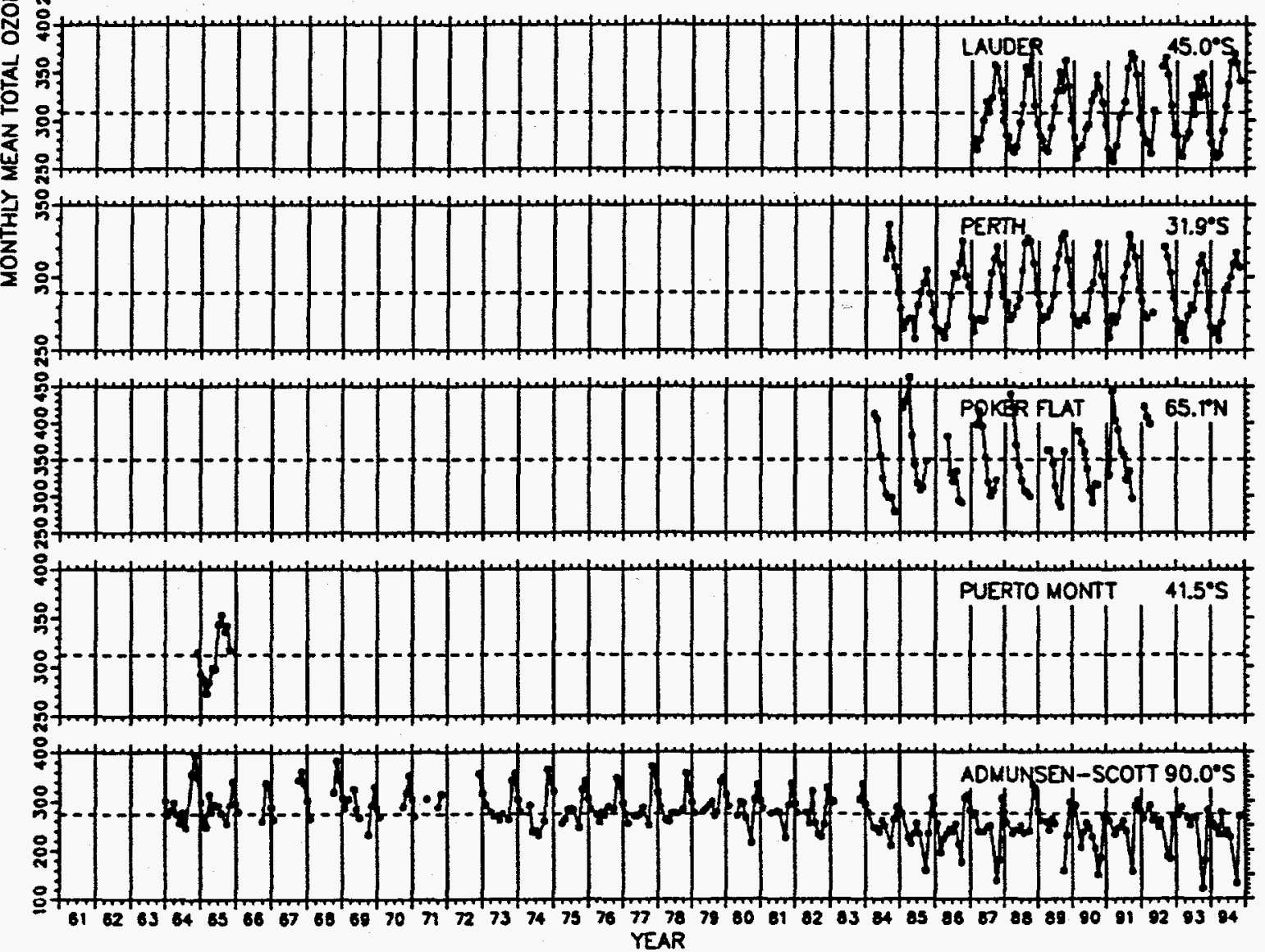

Figure 3. Total ozone monthly means from re-evaluated data for stations indicated in the plots. 
Table 3. Sample Re-evaluated Total Ozone Data Archived at the WODC

\begin{tabular}{|c|c|c|c|c|c|c|c|c|}
\hline $\begin{array}{l}6710193 \\
6720193 \\
6730193\end{array}$ & & & $\begin{array}{l}1800266 \\
2125321\end{array}$ & $\begin{array}{l}1900308 \\
1800275 \\
1900294\end{array}$ & $\begin{array}{l}1700326 \\
1805266 \\
1800288\end{array}$ & $\begin{array}{l}2100285 \\
1900277 \\
1800293\end{array}$ & $\begin{array}{l}1804258 \\
2100280\end{array}$ & 2125285 \\
\hline 6740193 & 2100295 & 1800267 & 1900262 & 1800258 & 1903276 & & & 283 \\
\hline 6710293 & 1900257 & 2100280 & 1905318 & 2100283 & 1900276 & & & 2100255 \\
\hline & 2100259 & 1904297 & 1900275 & 2100305 & & & & 2125378 \\
\hline $\begin{array}{l}6730293 \\
6740293\end{array}$ & $\begin{array}{l}1900301 \\
1904311\end{array}$ & $\begin{array}{l}1900278 \\
2100319\end{array}$ & 1900279 & & & 2100317 & 1900330 & $\begin{array}{r}1904319 \\
297\end{array}$ \\
\hline $\begin{array}{l}6740293 \\
6710393\end{array}$ & 2000330 & 1700303 & 1900293 & 1900305 & 1700314 & & & 1900293 \\
\hline & 1700287 & 1906309 & & 2700318 & & & 1900326 & 1900312 \\
\hline 6730 & 1705284 & 1900287 & 2100306 & & & 2100318 & 271 & 1900262 \\
\hline 6740393 & 1700275 & 1900275 & & & 1505326 & & 1800306 & 300 \\
\hline 6710493 & 1700295 & 1900308 & & & 1900313 & 1706332 & 1700330 & 1900303 \\
\hline 6720493 & 2200307 & & & 1700304 & 2100312 & 1700313 & $180 \mathrm{C}$ & 2100332 \\
\hline 6730493 & & & 1700 & 190 & 1700295 & 288 & 1700306 & \\
\hline 6740493 & & 1900278 & 1900298 & 1900305 & 1900315 & 1800334 & & 311 \\
\hline 6710593 & & & 1900 & 19003 & & & 2300332 & \\
\hline 6720593 & & 1900287 & 1600 & 1703293 & 2106280 & 2100283 & & \\
\hline 6730593 & 1705327 & 1800306 & 2100306 & 1700287 & 1900287 & & & 1704304 \\
\hline 6740593 & 2106313 & 1700299 & 1700292 & 2106307 & & & & 304 \\
\hline 6710693 & 2200298 & 1900309 & 1700335 & 1704323 & & & & \\
\hline 6720693 & 1700316 & 1900300 & 1900316 & & & 190 & & 1900304 \\
\hline 6730693 & & 2406341 & & & 2200285 & & 1900299 & \\
\hline
\end{tabular}

The reported total ozone value is chosen from the ensemble of observations made during each day to be representative of local apparent noon. Auxiliary information provided is the Universal Time (to the nearest hour) of the observation, the wavelengths on which measurements were made, and the viewing conditions (direct sun, clear zenith, cloudy zenith, etc.). The fourth data line in column 8 lists the mean total ozone for the month. The mean is computed from observations on all days of the month, and may not be representative of the true monthly mean if observations were made on fewer than 10 days. (For additional information about the coded data, see Guide Book No. 2. Ozone Data for the World, published by the Canadian Atmospheric Environment Service in cooperation with the World Meteorological Organization, Toronto, Canada).

Outliers in plotted, re-evaluated daily total ozone values were examined to identify erroneous data (e. g., due to observer error) as well as uncertain data whose reliability could not be definitively ascertained. Decisions regarding reliability of outliers were made following examination of raw and processed data for all the observations made during days when outliers occurred. The number of daily total ozone values identified as erroneous in the 327 station-years of data was surprisingly small, only 47 , or approximately $0.05 \%$ of the total body of data. Similarly, only 172 daily total ozone values were flagged to be uncertain, or about $0.2 \%$ of the entire data set.

Erroneous data have not been included in the WODC archive. Uncertain data are identified in the archive with asterisks. These, generally, should not be excluded from the main body of data when performing data analyses. 
Use of data from the Total Ozone Mapping Spectrometer (TOMS) instrument was not invoked in the data flagging process described above except as a check in the case of the MLO and the SMO data. For MLO during 19791993, the approximate life-time of the TOMS instrument, total ozone values on only 5 of 15 days; flagged as being uncertain, would have been rejected as erroneous had the TOMS data, also, been used as flagging criteria. For the same time interval, total ozone data on 12 of 21 days at SMO, flagged as uncertain on the basis of Dobson instrument data alone, would have been identified as erroneous considering, also, the TOMS measurements.

\section{Re-Evaluation of Observational Umkehr Data}

A sample record of Boulder, Colorado, Umkehr data prepared for archiving is shown in Table 4. Numbers in the first column of the table specify the days, months, and year of the observations. Those in column 2 indicate whether the observations were made in the morning (1) or afternoon (2); the wavelengths on which observations were made: (1), (3), and (4) being A, C, and $D$ wavelengths, respectively; the kinds of total ozone observations made, e.g., $(00)$ denotes AD-wavelength direct sun observations; and finally the measured

Table 4. Sample Coded Umkehr Data Archived at the WODC

\begin{tabular}{lllllllllllllllllllll}
\hline 010491 & 2100331 & 79 & 253 & 485 & 698 & 750 & 839 & 917 & 922 & 910 & 890 & 846 & 780 & 719 & 639 & 67 \\
010491 & 2300331 & 457 & 544 & 670 & 811 & 853 & 946 & 97 & 236 & 273 & 300 & 316 & 301 & 274 & 233 & 67 \\
010491 & 2400331 & 140 & 184 & 249 & 323 & 346 & 398 & 493 & 614 & 661 & 711 & 784 & 838 & 855 & 854 & 67 \\
040491 & 1100339 & 75 & 251 & 487 & 699 & 752 & 841 & 925 & 935 & 916 & 888 & 829 & 734 & 650 & 579 & 67 \\
040491 & 1300339 & 450 & 539 & 669 & 809 & 853 & 948 & 108 & 258 & 293 & 317 & 327 & 305 & 272 & 222 & 67 \\
040491 & 1400339 & 131 & 178 & 243 & 321 & 344 & 398 & 502 & 633 & 683 & 732 & 800 & 850 & 867 & 863 & 67 \\
080491 & 1100398 & 247 & 423 & 648 & 847 & 892 & 967 & 34 & 29 & 5 & 972 & 904 & 813 & 741 & 675 & 67 \\
080491 & 1300398 & 542 & 634 & 762 & 908 & 951 & 43 & 194 & 330 & 362 & 383 & 388 & 359 & 320 & 270 & 67 \\
080491 & 1400398 & 183 & 231 & 295 & 373 & 398 & 452 & 551 & 679 & 726 & 771 & 833 & 881 & 899 & 895 & 67 \\
090491 & 1100362 & 165 & 360 & 601 & 810 & 855 & 935 & 7 & 993 & 970 & 936 & 869 & 776 & 701 & 633 & 67 \\
090491 & 1300362 & 498 & 598 & 735 & 885 & 928 & 22 & 175 & 310 & 341 & 361 & 369 & 345 & 308 & 255 & 67 \\
090491 & 1400362 & 157 & 208 & 280 & 361 & 385 & 441 & 544 & 673 & 720 & 767 & 832 & 880 & 894 & 888 & 67 \\
100491 & 1100360 & 142 & 321 & 553 & 760 & 809 & 895 & 972 & 966 & 946 & 915 & 843 & 744 & 666 & 596 & 67 \\
100491 & 1300360 & 489 & 581 & 711 & 854 & 895 & 987 & 137 & 278 & 314 & 339 & 344 & 315 & 277 & 224 & 67 \\
100491 & 1400360 & 156 & 203 & 268 & 345 & 369 & 422 & 519 & 642 & 689 & 737 & 807 & 859 & 876 & 872 & 67 \\
170491 & 2100341 & -1 & -1 & -1 & -1 & -1 & 885 & 979 & 992 & 975 & 949 & 890 & 802 & 724 & 637 & 67 \\
170491 & 2300341 & -1 & -1 & -1 & -1 & -1 & 957 & 114 & 280 & 326 & 359 & 374 & 347 & 307 & 251 & 67 \\
170491 & 2400341 & -1 & -1 & -1 & -1 & -1 & 408 & 499 & 633 & 686 & 740 & 817 & 874 & 893 & 889 & 67 \\
260491 & 1300392 & -1 & -1 & 770 & 914 & 952 & 40 & 186 & 314 & 346 & 367 & 374 & 349 & 311 & 252 & 67 \\
270491 & 1300352 & 492 & 581 & 709 & 848 & 888 & 975 & 122 & 269 & 307 & 334 & 345 & 319 & 279 & 225 & 67 \\
\hline
\end{tabular}

total ozone amount in DU. Columns 3 to 16 of the table then list the measured Umkehr observation $\mathrm{N}$-values (Log $\mathrm{l} / \mathrm{I}$ + constant) to 3 decimal places for the solar zenith angles $60^{\circ}, 65^{\circ}, 70^{\circ}, 74^{\circ}, 75^{\circ}, 77^{\circ}, 80^{\circ}, 83^{\circ}, 85^{\circ}, 86.5^{\circ}, 88^{\circ}, 89^{\circ}$, and $90^{\circ}$. (When Log $1 / l^{\prime}+$ constant exceeds unity, the integer value is omitted.) The last column of Table 4 lists the WMO number of the station reporting the 
data. (For additional information about coded Umkehr data see Guide Book No. 2. Ozone Data for the World, published by the Canadian Atmospheric Environment Service, Downsview, Ontario, Canada, in cooperation with the WMO.)

While final $\mathrm{N}$-tables have been established for re-evaluating Umkehr data from all stations through 1995, considerable work remains to be done [G.L. Koenig, NOAACMDL, Boulder, Colorado]. Re-evaluation of the MLO record is nearing completion. Umkehr data from Boulder, Haute Provence, Huancayo, Lauder, Perth, and Poker Flat, processed in the past through 1991, are currently undergoing re-evaluation. Data from these stations obtained since 1991, however, await first processing.

\section{Acknowledgments}

Financial support for re-evaluation of portions of total ozone data records from the U.S.A. mainland stations, and from Hawaii and Samoa, was provided by the NOAA National Environmental Satellite, Data, and Information Service (NESDIS). G.L. Koenig of NOAACMDL is continuing re-evaluation of Umkehr data, with funding support from NESDIS.

\section{References}

Bass, A. M., and R. J. Paur, The ultraviolet cross-sections of ozone, I, The measurements, in Atmospheric Ozone, edited by C.S. Zerefos and A. Ghazi, pp. 606-610, D. Reidel, Nonwell, Mass., 1985.

DeLuisi, J. J., Shortened version of the Umkehr method for observing the vertical distribution of ozone, Applied Optics, 18, 3190-3197, 1979.

DeLuisi, J. J., E. G. Dutton, G. L. Koenig, D. V. Longenecker, and P. J. Reddy, Zenith-sky cloud detection for automated Dobson measurements, in Ozone in the Atmosphere, Proc. Quadrennial Ozone Symposium 1988 and Tropospheric Ozone Workshop, edited by R. D. Bojkov and P. Fabian, pp. 736-738, A Deepak, Hampton, Va, 1989.

Dobson Data Re-Evaluation Handbook, R. D. Hudson and W. G. Planet (eds.), NOAA Technical Report NESDIS 74, 142 pp., 1993; also available as WMO Report No. 29.

Fleig, A. J. P. K. Bhartia, C. G. Wellemeyer, and D. S. Silberstein, An assessment of the long-term drift in SBUV total ozone data based on comparison with the Dobson network, Geophys. Res. Lett., 13, 1359-1362, 1986.

Grass, R. D., and W. D. Komhyr, Traveling standard lamp calibration checks on Dobson ozone spectrophotometers during 1981-83, in Atmospheric Ozone, Proc. Quadrennial Ozone Symposium, Halkidiki, Greece, September 3-7, 1984, edited by C.S. Zerefos and A. Ghazi, pp. 376-380, Reidel, Doredrecht, 
Holland, 1985.

Grass, R. D., and W. D. Komhyr, Traveling standard lamp calibration checks of Dobson ozone spectrophotometers during 1985-87, in Ozone in the Atmosphere, Proc. Quadrennial Ozone Symposium 1988 and Tropospheric Ozone Workshop, R. D. Bojkov and P. Fabian Eds., pp. 144-146, A Deepak, Hampton, Va, 1989.

Komhyr W. D., Operations handbook-Ozone observations with a Dobson spectrophotometer, WMO Global Ozone Research and Monitoring Project, WMO Report No. 6, 125 pp, World Meteorological Organization, Geneva, 1980.

Komhyr, W. D., R. D. Grass, and R. K. Leonard, WMO 1977 international comparison of Dobson ozone spectrophotometers, in Proc. Quadrennial International Ozone Symposium, Boulder, Colorado, 4-9 August 1980, edited by J. London, Vol.I, pp. 27-32, National Center for Atmospheric Research, Boulder, Colorado, 1981.

Komhyr, W. D., R. D. Grass, R. D. Evans, R. K. Leonard, and G. M. Semeniuk, Umkehr observations with automated Dobson spectrophotometers, in Atmospheric Ozone, Proc. Quadrennial Ozone Symposium, Halkidiki, Greece, September 3-7, 1984, edited by C. S. Zerefos and A. Ghazi, pp. 371-374, D. Reidel, Dordrecht, Holland, 1985.

Komhyr, W. D., R. D. Grass, and R. K. Leonard, Dobson spectrophotometer 83:

A standard for total ozone measurements, 1962-1987, J. Geophys. Res., 94(D7), 9847-9861, 1989.

Komhyr, W. D., C. L. Mateer, and R.D. Hudson, Effective Bass-Paur ozone absorption coefficients for use with Dobson ozone spectrophotometers, Jour. Geophys. Res., 98(D11), 20,451-20,465, 1993.

Mateer, C. L., and H. U. Dütsch, Uniform evaluation of Umkehr observations from the world ozone Dobson data network: Part I, Proposed standard Umkehr evaluation technique, 105 pp., National Center for Atmospheric , Boulder, Colorado, 1964.

Mateer, C. L., and J. J. DeLuisi, A new Umkehr inversion algorithm, Jour. Atmos. Terrestrial Phys., 54(5), 537-556, 1992.

McPeters, R. D., and W. D. Komhyr, Long-term changes in SBUV/TOMS relative to world primary standard Dobson spectrophotometer 83, J. Geophys. Res., 96(D2), 2987-2993, 1991.

Report of the International Ozone Trends Panel 1988, Trends in Total Column Ozone Measurements, World Meteorological Organization Global Ozone Research and Monitoring Project Report No. 18, pp. 181-382, World Meteorological Organization, Geneva, 1990. 
Appendix A

\section{DOBSON DATA RE-EVALUATION HANDBOOK}

Section II: Re-evaluation of instruments Constants

October 1993

W.D. Komhyr

CIRES, University of Colorado, and

NOAACMDL, Boulder, Colorado 


\section{NOAA Technical Report NESDIS 66}

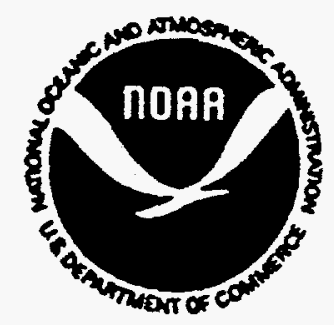

\section{DOBSON DATA RE-EVALUATION HANDBOOK}

\section{CONTRIBUTORS}

Walter D. Komhyr

Office of Oceanic and Atmospheric Research

Climate Monitoring and Diagnostic Laboratory

Boulder, Colorado

Alan Lapworth

United Kingdom Meterological Office

Karel Vanicek

Czech Hydrometeorological Instiutute

Solar and Ozone Observatory, Czech Republic

\section{EDITORS}

Robert D. Hudson

University of Maryland

College Park, Maryland

Walter G. Planet

Office of Research and Applications

Satellite Research Laboratory

Camp Springs, Maryland

Rumen Bojkov

World Meteorological Organization

Geneva, Switzerland

Washington, D.C.

August 1993

\section{U.S. DEPARTMENT OF COMMERCE \\ Ronald H. Brown, Secretary}

National Oceanic and Atmospheric Administration

Diana H. Josephson, Acting Under Secretary

National Environmental Satellite, Data, and Information Service Gregory W. Withee, Acting Assistant Administrator 
Table of Contents*

Introduction

Section 1: Examination of Instrument Histories

Section 2: Re-evaluation of Instrument Constants

Section 3: Independent Sources for Comparisons

Section 4: Conclusions

Acknowledgements

References

List of Figures

* Note: Only "Section 2: Re-evaluation of Instrument Constants" has been reproduced in Appendix I which describes in detail the methodology used in re-evaluating the NOAA total ozone data. 


\section{Introduction}

Two international Workshops addressing the state of the total ozone data set obtained by the global network of Dobson spectrophotometer stations have recently been held.

The First International Dobson Ozone Data Workshop was held september 11-13, 1991 in the Washington, D.C., area. The Workshop participants discussed the shortcomings of the existing data set and the need for a revised, more accurate data set useable for climate trend analyses and also for satellite comparisons. The participants recommended a second Workshop where those who have already reanalyzed their data sets would present their procedures and results to those station operators who have not yet begun reanalysis of their own data sets or who have applied incorrect procedures

The Second International Workshop was held June 1-3, 1992, in conjunction with the Quadrennial ozone symposium at Charlottesville, virginia. The major recommendation of the participants of this Second Workshop was to prepare a Handbook which will contain procedures, algorithms, etc, useful for reevaluating historical Dobson data sets. Primary authors and contributors were solicited from the international Dobson community.

This Handbook follows the consensus of the participants of the second Workshop. It has been reviewed by a significant segment of the Dobson community and thereby is considered a library reference alongside previous publications which have become standards over the years. 
SECTION II: RE-EVALUATION OF INSTRUMENT CONSTANTS

WALTER D. KOMHYR 


\section{Final Dobson spectrophotometer Data Processing Osing Re- Evaluated Instrument Constants}

This section describes procedures for determining and applying final corrections to raw observational Dobson spectrophotometer total ozone data obtained with instruments that have been periodically calibrated relative to World standard Dobson spectrophotometer $\mathbf{8 3}$ or relative to a secondary standard Dobson instrument with calibration traceable to instrument 83. The long-term ozone measurement precision of Dobson instrument 83 has been maintained to better than \pm 18 since 1962 [Komhyr et al., 1989]. The technique of calibrating all instruments of the global Dobson instrument network relative to instrument 83 standardizes total ozone measurements throughout the world, causing ozone data from all instruments to be directly comparable.

The correction methods described herein apply, furthermore, to Dobson instruments that have been operated according to procedures described by Dobson [1957] in the "Observers' Handbook for the Ozone Spectrophotometer" and by Komhyr [1980] in wMO Report No. 6 entitled "Operations Handbook--Ozone Observations with a Dobson Spectrophotometer." In addition to having "initial" and "final" calibrations relative to Dobson instrument 83, such instruments have had performed on them Hg lamp (wavelength-setting) tests and standard lamp tests at monthly intervals, and optical wedge re-calibrations every several years.

Data reprocessing procedures are described in the following sections for three cases. First, we consider the situation where a change occurred in the spectral characteristics of a Dobson instrument with time, but instrument optical wedge characteristics remained unchanged, and the observational data were not highly air mass $(\mu)$ dependent. Second, we treat the case where a Dobson instrument, with a well calibrated optical wedge, exhibits excessive $\mu$ dependency in observed ozone values relative to ozone values measured simultaneously with Dobson instrument 83 or with a secondary standard Dobson instrument. Finally, procedures are described for reprocessing and correcting Dobson instrument data obtained during observing time intervals when a change occurred in the instrument's optical wedge. In the case considered, corrections are also made for an additional change in instrument spectral characteristics and, for $\mu$-dependency in the observations.

The re-evaluated Dobson instrument data must be kept independent of other ozone data sets. Thus, ozone data from satellite instrument ozone observations, for example, should not be used in correcting the Dobson instrument data. 


\subsection{Use of Vigroux Ozone Absorption Coefficient scale for Data Reprocessing}

Final data processing for observations made during 1 July 1957 through 31 December 1991 should be performed using the vigroux [1953, 1967] ozone absorption coefficient scale, with the 1.388 $\mathrm{Cm}^{-1}$ absorption coefficient for $\mathrm{AD}$ wavelengths adopted as standard. Final results are ultimately to be archived at the WODC in Toronto, Canada, where all ozone values will be converted to the Bass-Paur [1985] ozone absorption coefficient scale as adapted for use with Dobson instruments by Komhyr et al. [1993]. The Bass-Paur [1985] ozone absorption coefficients were adopted for use throughout the world for Dobson instrument data processing beginning January 1, 1992 [Hudson et al., 1991]. On January 1, 1992, also, new improved Rayleigh molecular scattering coefficients were adopted for use for total ozone data processing [Komhyr et al., 1993]. The combined effect of the use of the new ozone absorption and molecular scattering coefficients has been to decrease ozone values by $2.6 \%$ compared to values obtained in the past.

\subsection{Dobson Instrument 83 and 65 Calibration scales}

Dobson instrument 83 calibration scales, relative to which Dobson instruments have been calibrated throughout the years, are the following:

\#33 June 18, 1962
$\# 83$ June 26, 1972
$\# 83$ August 26, 1976
$\# 83$ July 10, 1987
$\# 83$ August 26, 1991

Detailed information regarding slightly improved (F1) versions of these scales is presented in Appendix $2 . A$ in the form of $N_{A}, N_{C}$, and $\mathrm{N}_{\mathrm{D}}$ tables with associated reference standard lamp readings. Except for the June 26, 1972, calibration scale, $N_{A}, N_{C}$, and $N_{D}$ values in the updated $F 1$ scales are $0.004,0.002$, and 0.001 units larger, respectively, than those in the original scales, causing computed ozone values to be about $0.3 \%$ larger (at air mass -2 and total ozone $300 \mathrm{DU})$ than values obtained using the original scales. The small scale change arose from improved calculations of $\mu$ at Mauna Loa Observatory, the site of Dobson instrument 83 calibrations, as well as from correction of a small glitch in earlier computations of Julian calendar day.

Due to an inadvertent computational error, the $\$ 83$ June 26,1972 , calibration scale was originally established inaccurately. It is especially important, therefore, to correct any calibration data obtained in the past using this scale with the corrected and updated 83 June 26, 1972 F1 scale given in Appendix 2A. 
The instrument 83 calibration scales are basically interchangeable. Thus, either the $\$ 83 \mathrm{July} 10,1987 \mathrm{~F} 1$ scale or the $\$ 83$ August 26,1991 F1 scale can be used successfully in processing calibration data for a field Dobson spectrophotometer calibrated on, say, a day in 1989.

Because a number of Dobson spectrophotometers have been calibrated relative to NOAA/CMDL secondary standard Dobson instrument 65, we provide in Appendix 2.B the F1 calibration scales for instrument 65 . The scales are designated as:

$$
\begin{aligned}
& \text { \#65 April 10, } 1981 \text { F1 } \\
& \text { \#65 May 21, 1990 F1 } \\
& \text { \#65 August 30, } 1991 \text { F1. }
\end{aligned}
$$

Instrument 65 and 83 calibration scales were essentially identical through 1991 but began to diverge in 1992 causing instrument 65 ozone values to be larger than those of instrument 83 by $1 \%$. The cause of the discrepant results is under investigation.

\subsection{Data Reprocessing Procedures - Stable Dobson Instrument Optical wedge and No $\mu$-Dependency in the Observations}

We describe here the application of final corrections to Dobson instrument observational $N_{A}, N_{C}, N_{C,}$, and $N_{D}$ values obtained during a time interval when a significant change occurred in the spectral characteristics of the instrument as revealed by a "final" calibration of the instrument relative to a standard spectrophotometer, but when the instrument's optical wedge characteristics remained unchanged, and when $\mu$-dependence was not present in the observations. (In the example to follow, some $\mu$-dependency is present, but for purposes of illustration, we will assume it to be insignificant.). The data processing procedures described here are useful, also, for improving the quality of ozone data obtained during a time interval for which an "initial" instrument calibration relative to a standard may have lacked high precision.

Gradual changes in Dobson instrument spectral characteristics may occur, for example, due to corrosion of the instrument's cobalt filter', contamination of the instrument's optics, or an aging photomultiplier tube. While such changes in special characteristics are largely compensated for by the application of monthly standard lamp test corrections during data processing, residual errors may remain. Abrupt changes in Dobson instrument spectral characteristics may arise due to accidental instrument jarring which may disturb instrument optical alignment, sudden

\footnotetext{
'This occurs in humid atmospheres when the instrument silica gel air drier is not renewed often enough.
} 
optical contamination, or when partial damage occurs to the instrument photomultiplier due to inadvertent exposure to excessive light.

As an illustrative example of such data reprocessing, Appendix 2.C shows "initial" and "final" calibration data for Dobson spectrophotometer 33 relative to standard instrument 83 obtained April 15, 1986, and May 11, 1988. The "initial" calibration data include newly established reference $N$ tables and standard lamp readings dated April 15, $1986 \mathrm{R1}$. The "final" instrument 33 calibration, performed May 11, 1988, showed that mean corrections of $-0.59,-0.72$, and -1.79 were needed, respectively, to $100 \mathrm{~N}_{\mathrm{A}}$, $100 \mathrm{~N}_{\mathrm{C}}$, and $100 \mathrm{~N}_{\mathrm{D}}$ values ${ }^{2}$ of the April 15, $1986 \mathrm{RI} \mathrm{N}$ tables used for data processing. (These mean corrections were deduced from instrument 33 and 83 comparison ozone data obtained in the $\mu-$ range 1.15-2.5.). The correction needed to $100 \mathrm{~N}_{A D}$ values was, therefore, 1.21 , which is significant.

In final processing of April 15, 1986-May 11, 1988, observational ozone data, we begin by using the reference $N$ tables and standard lamp readings dated April 15, $1986 \mathrm{R} 1$ (Appendix 2.C). For an ADDSGQP type observation, for example, correct $N_{A}$ and $N_{D}$ values are deduced from

$$
\begin{aligned}
& \mathrm{N}_{A}=\mathbf{N}_{A}^{\prime}+\Delta \mathrm{N}_{\mathbf{A}}+\Delta \mathrm{N}_{\mathbf{A}}(t) \\
& \mathbf{N}_{\mathbf{D}}=\mathbf{N}_{\mathbf{D}}^{\prime}+\Delta \mathrm{N}_{\mathbf{D}}+\Delta \mathrm{N}_{\mathbf{D}}(t)
\end{aligned}
$$

Where $N_{A}^{\prime}$ and $N_{D}^{\prime}$ are obtained from the April 15, 1986 R1 $N$ tables corresponding to the Dobson instrument observational dial readings $R_{A}$ and $R_{D}$, respectively; the $\Delta N^{\prime} s$ are the standard lamp corrections to the $N$ values, determined from differences in reference standard lamp $N$ values dated April 15, 1986 RI and $N$ values determined by linear interpolation of routine monthly standard lamp test data; and the $\Delta \mathrm{N}(t)$ are the time-dependent $N-$ value drift corrections determined from the "final" calibration of instrument made May 11, 1988 (Appendix 2.C). The time dependent function to be used in applying the drift corrections may be linear, exponential, step, etc., or a combination of these. Standard lamp test history as well as other pertinent instrument information should be examined in establishing the time dependent function to use when applying the drift corrections.

The following numerical example illustrates the procedures described above for final data processing.

(a) We consider an AD-DSGQP observation made at Bismarck, North Dakota, April 3, 1987, at 18h 20m 00s UT $(\mu=1.339)$. The

A convention is employed in expressing $N$ values in Appendices 2.C-2.E whereby true $N$ values are multiplied by 100 .

$$
\text { II }-4
$$


observation yielded mean $R_{A}=122.4^{\circ}$ and mean $R_{D}=39.9^{\circ}$. From the $N$ tables dated April 15, 1986 R1 (Appendix 2.C), we obtain $100 \mathrm{~N}_{\mathrm{A}}^{\prime}=98.1$ and $100 \mathrm{~N}_{\mathrm{D}}^{\prime}=33.4$.

(b) Standard lamp corrections needed this day (not shown), determined by linear interpolation from lamp tests made March 29, 1987, and April 27, 1987, were $100 \Delta \mathrm{N}_{\mathrm{A}}=-1.0$ and $100 \Delta N_{D}=-0.7$.

(c) With regard to the $\Delta \mathrm{N}(t)$ corrections, Appendix 2.C shows that during April 15, 1986 to May 11, 1988, Dobson instrument 33 standard lamp $N$ value readings changed by about two 100N units. Examination of the monthly standard lamp test data for the instrument showed the change to have occurred approximately linearly with time. Therefore, using the $N$-value drift correction data shown on the last page of Appendix 2.C, and considering that April 3, 1987, occurred 0.467 of the way into the time interval April 15, 1986-May 11, 1988, we have that

$$
\begin{aligned}
& 100 \Delta \mathrm{N}_{A}(t)=0.467(-0.59-0.00)=-0.276 \\
& 100 \Delta \mathrm{N}_{D}(t)=0.467(-1.79-0.00)=-0.836
\end{aligned}
$$

(d) Evaluating relations (1) and (2), then we have

$$
\begin{aligned}
& N_{A}=0.981-0.010-0.003=0.968 \\
& N_{D}=0.334-0.007-0.008=0.319
\end{aligned}
$$

Finally, total ozone amount for the observation, computed using vigroux ozone absorption coefficients, is

$$
X_{A D}=1000\left[\frac{0.968-0.319}{1.388(1.339)}-0.008\right]=341 \mathrm{DU}
$$

Monthly standard lamp N-value corrections and the $N$-value calibration drift corrections should be applied not only to direct sun observational data, but also to data obtained fron zenith-sky observations. Corrections to $\mathrm{N}_{C}$ values are determined from routine, monthly standard lamp tests. For standard lamp corrections to be reliable, it is important always to have operated the standard lamps at correct voltages. 


\subsection{Data Reprocessing Procedures - stable Instrument Optical Wedge, but Data Bxhibiting $\mu$-Dependency}

Here we consider the situation where calibration ozone data, obtained with a spectrophotometer having a well calibrated, stable optical wedge, exhibit significant $\mu$-dependency relative to ozone measured coincidentally with a standard spectrophotometer. Cause of the $\mu$-dependency may be use with the instrument of an erroneous wavelength setting table; some defect in instrument optical alignment; or one or more defective optical components, e.g., a quartz prism fabricated from inferior quality quartz that attenuates ultraviolet radiation excessively, a cobalt filter with insufficient opacity at near ultraviolet wavelengths, or a corroded cobalt filter that slightly alters the effective wavelengths passing through the Dobson instrument during observations. Because the exact cause of the $\mu$-dependency is often difficult to determine, it is important not to over correct for it. If $A D$ wavelength calibration ozone data for an instrument vary by less than about $\pm 1 \%$ relative to the standard Dobson instrument ozone values for $1.15<\mu<2.5$, then $\mu$-dependent corrections are most likely not worthwhile applying. Corrections may not be necessary, also, when single pair wavelength ozone observations exhibit significant $\mu$-dependency, but double pair wavelength observations do not.

\subsubsection{Observations Made on Non-standard Wavelengths}

This may occur when a Q-setting table is inadvertently established incorrectly for one or more of the Dobson instrument wavelength pairs. The standard ozone absorption coefficients, then, do not apply. However, by using more appropriate (effective) absorption coefficients, the $\mu$-dependency in the ozone observations can be largely eliminated.

The procedure for establishing a double pair wavelength (e.g., AD wavelength) effective ozone absorption coefficient for a spectrophotometer (say, instrument 63) and calibrating it relative to a standard spectrophotometer (say, instrument 83 ) is as follows: Simultaneous $A D-D S G Q P$ observations are made with the two instruments during one-half day as $\mu$ varies between 1.15 and 2.5. For instrument 63 properly calibrated, we have for any observations pair

$$
X_{A D}^{63}=X_{A D}^{83}
$$

and

$$
\frac{N_{A D}^{63}+\Delta N_{A D}^{63}}{\alpha_{A D}^{63} \mu}-\frac{\beta_{A D} m p}{\alpha_{A D}^{63} \mu p_{0}}=\frac{N_{A D}^{83}}{\alpha_{\lambda D}^{83} \mu}-\frac{\beta_{A D} m p}{\alpha_{A D}^{83} \mu p_{0}}
$$


where

and

$$
\Delta \mathrm{N}_{A D}^{63}=\text { Correction needed to Dobson instrument } 63 \mathrm{~N}_{A D} \text { values, }
$$

$\alpha_{A D}^{63}=$ Effective $A D$ wavelength ozone absorption coefficient for instrument 63 .

In the above relation, the two terms containing the Rayleigh scattering coefficients, $\beta_{A D}$, are approximately equal and cancel for observations on double pair wavelengths. The relation may then be written as

$$
N_{A D}^{63}=\alpha_{A D}^{63}\left[\frac{N_{A D}^{83}}{\alpha_{A D}^{83}}\right]-\Delta N_{A D}^{63}
$$

A plot of $N_{A D}^{63}$ vs. $N_{A D}^{83} / \alpha_{A D}^{83}$ observational data yields a straight line with slope $\alpha_{A D}^{63}$ and intercept $-\Delta N_{A D}^{63}$. Thus, the effective $A D$ wavelength ozone absorption coefficient is determined for the instrument, together with the correction to the instrument's Ntables.

For single pair wavelength observations (e.g., the D wavelengths), the Rayleigh scattering terms referred to above become significantly different, so that the above method cannot be used e.g., to determine $\alpha_{D}^{63}$. However, $\alpha_{D}^{63}$ and corrections to $N_{D}^{63}$ values can be obtained by a successive approximation method. For an instrument measuring, e.g., ozone amounts too high at low $\mu$, ozone amounts are computed using decreased $\alpha_{D}^{63}$ and $N_{D}^{63}$ values. Final $\alpha_{D}^{63}$ and $N_{D}^{63}$ values are chosen that yield measured ozone amounts closely similar to those obtained with the standard instrument 83 for all $\mu$.

\subsubsection{Correcting for $\mu$-Dependency Due to other Causes}

This section describes more general but approximate procedures for correcting for $\mu$-dependency in ozone observations arising, for example, from light scattering within the instrument or other causes, including wavelength setting errors. As shown in section 2.5, the method can be used, if necessary, when correcting ozone data obtained with a spectrophotometer whose optical wedge characteristics changed with time.

For illustration, Appendix 2.D shows "initial" and "final" calibration data for Dobson spectrophotometer 79 , relative to standard Dobson instrument 83 , obtained August 25,1981 , and June 19, 1985. Note that for the August 25, 1981 RI calibration, 
significant $\mu$-dependent $N_{A}-, N_{C^{-}}$, and $N_{D}$-value differences exist for instrument 79 relative to corresponding $N$-values for instrument 83 . These are defined by the linear relations:

$$
\begin{aligned}
& 100 \Delta \mathrm{N}_{A}(\mu)_{i}=-27.28+0.9992 \mu+25.51 \\
& 100 \Delta \mathrm{N}_{C}(\mu)_{i}=-26.38+0.5846 \mu+25.34 \\
& 100 \Delta \mathrm{N}_{D}(\mu)_{i}=-28.55+0.5106 \mu+27.65
\end{aligned}
$$

$\Delta \mathrm{N}_{\mathrm{AD}}$ and $\Delta \mathrm{N}_{\mathrm{CD}}$ differences for the two instruments on the other hand, are relatively $\mu$-independent giving rise to $\mu$-dependent ozone differences for instrument 79 versus instrument 83 of only \pm 0.58 for $1.15 \leq \mu \leq 3.2$.

The final calibration data for Dobson instrument 79 , of June 19, 1985 (Appendix 2.D), not only show a highly significant $\mu-$ dependency in $N_{C}$ values relative to Dobson instrument $83 N_{C}$ values but also slope reversals in the case of the instrument 79 $\mu$-dependent $N_{C}$ and $N_{D}$ values compared to corresponding results obtained in 1981. Again, $\Delta \mathrm{N}_{\mathrm{AD}}$ differences for the two instruments are relatively independent of $\mu$, but $\Delta \mathrm{N}_{\mathrm{CD}}$ differences are highly $\mu$-dependent, causing instrument $79 x_{C D}$ values to be underestimated by $4.7 \%$ at $\mu=1.33$ but overestimated at $\mu=2.85$ by 1.9\%. As shown in Appendix 2.D, the $\mu$-dependency in the instrument 79 calibration data of June 19, 1985, is defined by

$$
\begin{aligned}
& 100 \Delta \mathrm{N}_{A}(\mu)_{f}=0.7067-3.5786 \mu+1.1641 \mu^{2}-0.0903 \mu^{3} \\
& 100 \Delta \mathrm{N}_{C}(\mu)_{f}=-0.1559+2.4719 \mu-2.5068 \mu^{2}+0.4657 \mu^{3} \\
& 100 \Delta \mathrm{N}_{D}(\mu)_{f}=-5.3086+10.2567 \mu-5.1692 \mu^{2}+0.7756 \mu^{3}
\end{aligned}
$$

Final processing of ozone data obtained with Dobson instrument 79 during August 25, 1981-June 19, 1985, is performed using the August 25, $1981 \mathrm{R} 1 \mathrm{~N}$ tables and reference standard lamp data given in Appendix 2.D. To process an observation made, for example, on $A$ and $D$ wavelengths, first convert observed mean $R_{A}$ and $R_{D}$ (instrument dial reading) values to $N_{A}^{\prime}$ and $N_{D}^{\prime}$ values where the primes indicate (as in section 2.3) that additional $\mathrm{N}$-value corrections are needed. Then apply standard lamp corrections $\Delta \mathrm{N}_{\mathrm{A}}$ and $\Delta \mathrm{N}_{\mathrm{D}}$ to these values based on monthly standard lamp tests as described in section 2.3. Corrected $N_{A}$ and $N_{D}$ values for the observation are then obtained from

$$
\begin{aligned}
& N_{A}=N_{A}^{\prime}+\Delta N_{A}+\Delta N_{A}(\mu, t) \\
& N_{D}=N_{D}^{\prime}+\Delta N_{D}+\Delta N_{D}(\mu, t)
\end{aligned}
$$


where $\Delta N_{A}(\mu, t)$ and $\Delta N_{D}(\mu, t)$ are needed additional $\mu$ and $t$ ime dependent $\mathrm{N}$-value corrections.

Information on how the $\mu$-dependent $N$-value correction changed with time must be gleaned from an examination of the instrument's standard lamp test history and other relevant instrument information. For the purpose of illustration, we assume here that the change occurred approximately linearly with time and independently of measured total ozone. We have then

$$
\begin{aligned}
& \Delta \mathrm{N}_{A}(\mu, t)=\Delta \mathrm{N}_{A}(\mu)_{i}+r\left(\Delta \mathrm{N}_{A}(\mu)_{i}-\Delta \mathrm{N}_{A}(\mu)_{i}\right) \\
& \Delta \mathrm{N}_{D}(\mu, t)=\Delta \mathrm{N}_{D}(\mu)_{i}+r\left(\Delta \mathrm{N}_{D}(\mu)_{i}-\Delta \mathrm{N}_{D}(\mu)_{i}\right)
\end{aligned}
$$

when $r$ is the fraction of time that elapsed on the day of the observation since August 25, 1981, within the observing time interval under consideration.

The following numerical example illustrates the procedures described above for final data processing.

(a) We consider an AD-DSGQP observation made at Nashville, Tennessee, June 29, 1983 at $18 \mathrm{~h}, 19 \mathrm{~m}$, OOS UT $(\mu=1.033)$. The observation yielded mean $R_{A}=96.9^{\circ}$ and $R_{D}=51.3^{\circ}$. From the $N$ tables dated August 25, 1981 RI (Appendix 2.D) we obtain, corresponding to the instrument dial readings, $100 \mathrm{~N}_{\mathrm{A}}^{\prime}=67.9$ and $100 \mathrm{~N}_{\mathrm{D}}^{\prime}=22.1$.

(b) Corrections (not shown) needed on June 29, 1983 to $N$ values, based on monthly standard lamp test data, were $100 \Delta \mathrm{N}_{\mathrm{A}}=3.0$ and $100 \Delta N_{D}=2.4$.

(c) Evaluating relations (3), (5), (6), and (8) above for $\mu=$ 1.033 to obtain the needed $\mu$-dependent $N$-value corrections, we have

$$
\begin{gathered}
100 \Delta \mathrm{N}_{A}(\mu)_{i}=-27.28+1.032+25.51=-0.738 \\
100 \Delta \mathrm{N}_{D}(\mu)_{i}=-28.55+0.527+27.65=-0.373 \\
100 \Delta \mathrm{N}_{\mathrm{A}}(\mu)_{\mathrm{f}}=0.7067-3.6967+1.2422-0.0995=-1.847 \\
100 \Delta \mathrm{N}_{\mathrm{D}}(\mu)_{\mathrm{f}}=-5.3086+10.5952-5.5160+0.8549=0.626
\end{gathered}
$$

(d) For the observation made June 29, 1983, the fraction of time, $r$, that elapsed since August 25, 1981 within the time interval August 25, 1981-June 19, 1985, is 0.483 .

Evaluating relations (11)-(12) we then have

$$
\Delta \mathrm{N}_{\mathrm{A}}(\mu, t)=-0.0074+0.483(-0.0185+0.0074)=-0.013
$$




$$
\Delta \mathrm{N}_{\mathrm{D}}(\mu, t)=-0.0037+0.483(0.0063+0.0037)=0.0011
$$

(e) Relations (9) and (10) are then evaluated to yield

$$
\begin{aligned}
& N_{A}=0.679+0.030-0.013=0.696 \\
& N_{D}=0.221+0.024+0.001=0.246
\end{aligned}
$$

Finally, total ozone amount for the observation, computed using vigroux ozone absorption coefficients, is

$$
X_{\mathrm{AD}}=1000\left[\frac{0.696-0.246}{1.388(1.033)}-0.009\right]=305 \mathrm{DU}
$$

The method described above for final processing of $\mu$-dependent observational ozone data involves $\mathrm{N}$-value determinations from "initial" calibration mean $\mathrm{N}$ tables (derived from instrument 79 and 83 comparison calibration observations made at $1.15<\mu<2.5$ ) to which are added $\mu$-dependent $N$-value corrections. An alternate procedure, yielding equivalent results, would be to use, instead, $\mu$-dependent $N$ tables comprised of $G$ tables with associated $\mu-$ dependent $\Delta G$ values that convert the $G$ tables to $N$ tables. For the example considered, the $\mu$-dependent $\Delta G$ values are defined by the three linear relations that appear on the top of the third page of Appendix 2.D.

\subsection{Data Processing Procedures - Unstable Dobson Instrument Optical Wedge, Change in Instrument spectral Characteristics, and $\mu$-Dependency in the Observations}

We finally consider the situation where, during a certain time interval, a change occurred in the Dobson instrument optical wedge characteristics. Here it is assumed that a reasonable estimate can be made of how the wedge changed with time, whether linearly, exponentially, or via a step function, etc.; and that optical wedge calibrations and instrument calibrations relative to a standard spectrophotometer were performed prior to and after the time interval of the wedge change. With such information, it is possible to improve reprocessed ozone data quality not only by largely accounting for the optical wedge change but also by substantially correcting for additional long-term instrument calibration drift that may have occurred due to causes described in sections 2.3 and 2.4 as well as for $\mu$-dependency in the observations.

As an illustrative example, we consider total ozone data obtained at Nashville, Tennessee, with Dobson instrument 79 between september 10,1975, and August 14, 1981. During this time 
interval the spectral characteristics of the optical wedge in instrument 79 changed significantly by up to about 0.035 unit, as indicated in Table 1.

Table 1. Optical Wedge Density Changes for Dobson

Instrument 79 During september 9, 1975-August 24, 1981.

Inst. Dial

Readings $\left(^{\circ}\right) \quad G_{A} 1981-G_{A} 1975 G_{C} 1981-G_{C} 1975 \quad G_{D} 1981-G_{D} 1975$

$\begin{array}{rrrr}10 & 0.002 & 0.000 & 0.001 \\ 50 & -0.005 & -0.005 & -0.006 \\ 100 & -0.018 & -0.017 & -0.018 \\ 150 & -0.021 & -0.022 & -0.021 \\ 200 & -0.030 & -0.033 & -0.032 \\ 250 & -0.033 & -0.037 & -0.032 \\ 290 & -0.029 & -0.035 & -0.032\end{array}$

For final data processing, it is necessary to adopt some functional form for the temporal optical wedge density changes. As much available information as possible should be used in deciding on what functional form to adopt. We begin by examining standard lamp test data for Dobson instrument 79 (Figure 1). Here standard lamp $79 \mathrm{C}$ readings appear to be relatively constant during September 29, 1975-March 31, 1979, but then increase with time through August 14, 1981. Such data imply that the change in optical wedge densities may have begun about April 1, 1979, and proceeded in a linear fashion through 1981. But additional data suggest a different scenario. Examining all available calibration data (not shown) for instrument 79, we find that for the time interval defined by instrument 79 optical wedge calibration dates of July 23, 1962; July 7, 1971; October 17, 1973; September 9, 1975; August 24, 1981; and June 27, 1985, the optical wedge density rates of change were $0 \% \mathrm{yr}^{-1}, 0.28 \mathrm{yr}^{-1}, 0.68 \mathrm{yr}^{-1}, 0.58 \mathrm{yr}^{-}$ 1 , and $0.3 \% \mathrm{yr}^{-1}$, respectively. (These were determined from optical wedge density data for instrument 79 R-dial readings of $200^{\circ}$, and are assumed to be representative of density change rates throughout the wedge.) Thus the conclusion must be that instrument 79 optical wedge density characteristics changed approximately linearly throughout the entire observing interval under consideration, namely, September 10, 1975-August 14, 1981. What then caused the change in the character of the standard lamp readings beginning about April 1, 1979 (Figure 1)? 

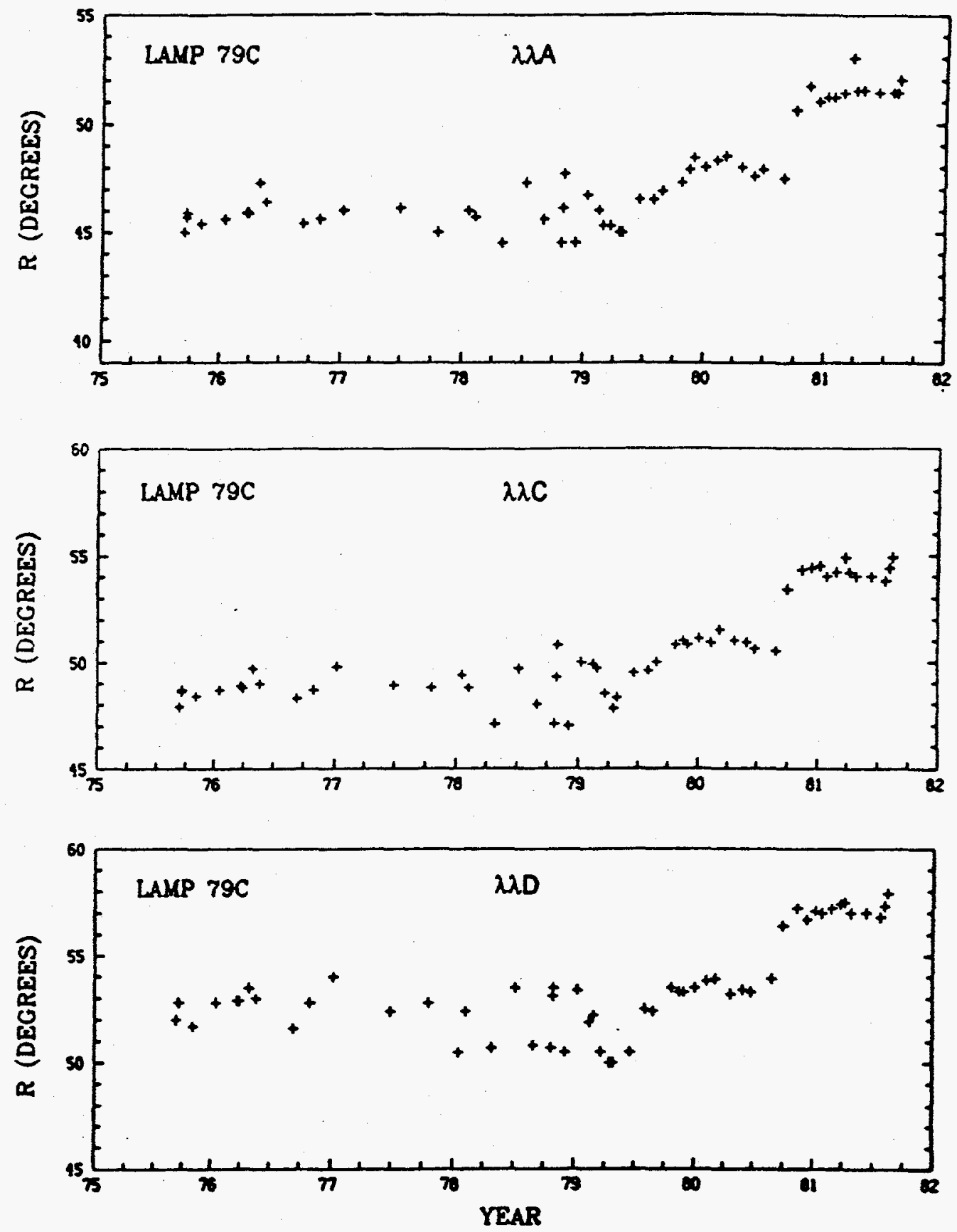

Figure 1. Standard Lamp 79C test data for Nashville Dobson instrument 79 obtained during September 1975August 1991. 
our historical records show that in August 1981, when instrument 79 was received in Boulder, Colorado, the cobalt filter in front portions of the filter exhibiting a milky coloration. As indicated previously, filter corrosion occurs in humid air. 1975 the filter exhibited no sign of corrosion.) He surmise, therefore, that following about April 1, 1979, silica gel air drier within the instrument was not renewed often enough to keep the instrument dry. As a result, instrument 79 optical characteristics changed approximately linearly with time during April 1, 1979-August 24, 1981, due to cobalt filter deterioration.

In final processing of the total ozone data obtained at Nashville we, therefore, take the spectral characteristics of Dobson instrument 79 to have changed in part linearly with time during september 9, 1975-August 24, 1981, due to optical wedge density changes, and additionally linearly with time during April 1 , 1979-August 24, 1981, due to cobalt filter deterioration. Final data processing should therefore, proceed as follows, where corrections are also made for $\mu$-dependency in the instrument 79 observational data that were partly induced by the cobalt filter corrosion.

Appendix 2.E presents "initial" calibration data for Dobson instrument 79 relative to Dobson instrument 83 obtained September 10, 1975. Instrument 79 optical wedge density tables used in analyzing the calibration data were those determined september 9 , 1975. Note (Appendix 2.E) that the calibration data for instrument 79 exhibit little $\mu$ dependency relative to instrument 83 data. The new calibration scale for Dobson instrument 79, dated September 10, $1975 \mathrm{RI}$, is presented in Appendix 2.E.

A "final" calibration of instrument 79 was conducted in Boulder on August 14, 1981. Appendix 2.E presents usual analysis data for the instrument comparison where standard lamp corrections to the data are applied and a change in instrument 79 calibration relative to its calibration of September $19,1975 \mathrm{Rl}$, is determined. (No account is taken here of instrument 79 optical wedge density changes.) Note (Appendix 2.E) the large instrument 79 calibration change (i.e., $\Delta \mathrm{N}_{\mathrm{AD}}=0.0244$ ) that occurred during September 10, 1975-August 14, 1981, that was not corrected for by the application of standard lamp test data. This calibration change corresponds to AD-DSGQP ozone measurement errors on August 14,1981 , of 5.68 at $\mu=1$, and 28 at $\mu=3$. A large calibration change is evident, also, for $C D$ wavelength observations made with instrument 79 .

In Appendix 2.E the instrument 79 "final" calibration data of August 14, 1981, are processed using correct optical wedge density data, determined August 24,1981 . When processing the 
data, $G A$ and $G D$ values in the tables corresponding to instrument 79 observational $R_{A}$ and $R_{D} R$-dial readings, respectively, are converted to $N_{A}^{\prime}$ and $N_{D}^{\prime}$ values ${ }^{3}$ using the relations

$$
\begin{aligned}
& N_{A}^{\prime}=G_{A}+\left(N_{A S}-G_{A S}\right) \\
& N_{D}^{\prime}=G_{D}+\left(N_{D S}-G_{D S}\right)
\end{aligned}
$$

where $G_{A s}$ and $G_{D S}$ are the $G$ values obtained from the $G$ tables dated August 24,1981 , corresponding to reference standard lamp readings $R_{A S}$ and $R_{D s}$ obtained August 14,1981 ; and $N_{A s}$ and $N_{D s}$ are the reference lamps $N$ values established september 10, 1975 (Appendix 2.E). In practice, mean results of tests with two or more reference standard lamps are used for the N-value determinations. For the example under consideration, mean $\mathrm{N}_{A S}$ $G_{A S}=-0.292$ and mean $N_{D S}-G_{D S}=-0.304$ were computed from tests made August 14, 1981, with instrument 79 reference standard lamps 79C and 79D (Appendix 2.E).

Results of processing of the instrument 79 "final" calibration data of August 14, 1981, are summarized in Appendix 2.E. Note that use of correct optical wedge densities in the data processing has reduced former mean $N_{A D}$ and $N_{C D}$ calibration error of -0.0244 and -0.0099 (Appendix 2.E) to -0.0120 and -0.0035 , respectively. We interpret the residual error to have resulted from Dobson instrument 79 spectral characteristics changes due to cobalt filter deterioration. Note that the errors exhibit a $\mu-$ dependency, part of which was an original spectral characteristic of Dobson instrument 79, but part of which was induced by the cobalt filter corrosion.

In reprocessing total ozone observational data (i.e., applying final corrections to the data) for example, for an $A D$-wavelength observation, it is first necessary to evaluate relations (13) and (14). Here the standard lamp $N_{A s}$ and $N_{D S}$ values are constants (Appendix 2.E), while the $G_{A s}$ and $G_{D s}$ values are derived for the day of the total ozone measurements from linear interpolation of monthly standard lamp test $R_{A s}$ and $R_{D s}$ values, as well as from the G-tables dated September 9, 1975, and August 24, 1981. The $G_{A}$ and $G_{D}$ terms in relations (13) and (14), corresponding to mean $R_{A}$ and $R_{D}$ values for the ozone observation, are also derived by linear interpolation from the september 9, 1975, and the August 24,1981 , G-tables. $N_{A}^{\prime}$ and $N_{D}^{\prime}$ values thus computed from (13) and (14) for the $A D$-wavelength observations are corrected for temporal drift of the optical wedge densities of Dobson instrument 79 , but they are not corrected for the change in

${ }^{3}$ Primes associated with $N_{A}$ and $N_{D}$ values indicate that additional corrections to these values may be needed. 
instrument 79 spectral characteristics that occurred during Apr11 1, 1979-August 24, 1981, due to cobalt filter deterioration, including $\mu$-dependency. Denoting these additional, time dependent corrections by $\Delta N_{A}(\mu, t)$ and $\Delta N_{D}(\mu, t)$, we have

$$
\begin{aligned}
& N_{A}=N_{A}^{\prime}+\Delta N_{A}(\mu, t) \\
& N_{D}=N_{D}^{\prime}+\Delta N_{D}(\mu, t)
\end{aligned}
$$

where the $N_{A}$ and $N_{D}$ values are now corrected not only for the optical wedge calibration drift, but also for the cobalt filter deterioration effects as well as for observational time-dependent $\mu$-dependency.

As indicated earlier, a small $\mu$-dependency in instrument 79 ozone observations relative to instrument 83 ozone observations is evident in the "initial" calibration of instrument 79 on September 10, 1975 (Appendix 2.E). While a $\mu$-dependency of this magnitude would not normally be considered for correction, we account for it here mainly to demonstrate the technique. As shown in Appendix 2.E, applicable $\mu$-dependent corrections for Dobson instrument 79 september 10, 1975, were

$$
\begin{aligned}
& \Delta N_{A}(\mu)_{i}=A+B \mu-\overline{G_{A}} \\
& \Delta N_{D}(\mu)_{i}=C+D \mu-\overline{G_{D}}
\end{aligned}
$$

where $A, B, C$, and $D$ are constants, and the $\bar{G}_{A}$ and $\bar{G}_{D}$ are mean G-values deduced from the comparison observations made at $1.15<\mu<2.5$ that, when added to the $G$ tables dated september 9, 1975, convert them to $N$-tables dated september 10, 1975. These Iinear relations ${ }^{4}$ express $\mathrm{N}$-value differences as a function of $\mu$ for Dobson instruments 79 and 83 on september 10, 1975. They are assumed to be independent of total ozone amount, and to remain unchanged during September 10, 1975-March 31, 1979, the time interval when standard lamp test data for instrument 79 remained relatively constant.

"Final" calibration data of August 14, 1981 (Appendix 2.E), with optical wedge density drift corrected, show a change in instrument 79 spectral characteristics, including a change in the $\mu$-dependency of the comparison observations. Applicable $\mu-$ dependent $N$-value corrections on this day (Appendix 2.E) are shown to be

\footnotetext{
cuble.

For other Instrument calibrations, these relations may be parabollc or $I I-15$
} 


$$
\begin{aligned}
& \Delta \mathrm{N}_{\mathrm{A}}(\mu)_{f}=\mathrm{E}+\mathrm{F} \mu \\
& \Delta \mathrm{N}_{\mathrm{A}}(\mu)_{f}=J+\mathrm{K} \mu
\end{aligned}
$$

where, again, E, F, H, and $\mathrm{K}$ are constants.

During final data processing, then, two time intervals must be considered in applying the above $\mathrm{N}$-value corrections to observational data. For ozone observations made during september 10, 1975-March 31, 1979, when instrument spectral characteristics appear to have remained constant (except for the wedge density change that has been accounted for), correct observational $\mathrm{N}-$ values [relations (13) and (14)] are given by

$$
\begin{aligned}
& \mathbf{N}_{\mathrm{A}}=\mathbf{N}_{\mathrm{A}}^{\prime}+\Delta \mathrm{N}_{\mathrm{A}}(\mu)_{\mathrm{i}} \\
& \mathbf{N}_{\mathrm{D}}=\mathbf{N}_{\mathrm{D}}^{\prime}+\Delta \mathrm{N}_{\mathrm{D}}(\mu)_{\mathrm{i}}
\end{aligned}
$$

For the time interval April 1 to August 14, 1979, on the other hand, the $\mu$-dependent corrections are assumed to have changed linearly with time from those given by (17) and (18) to those given by (19) and (20). Thus for ozone observations made during this latter time interval, correct $N$-values for an ozone observation are given by

$$
\begin{aligned}
& \mathrm{N}_{A}=\mathrm{N}_{A}^{\prime}+\Delta \mathrm{N}_{A}(\mu)_{i}+r\left[\Delta \mathrm{N}_{\mathrm{A}}(\mu)_{\mathrm{f}}-\Delta \mathrm{N}_{\mathrm{A}}(\mu)_{\mathrm{i}}\right] \\
& \mathrm{N}_{\mathrm{D}}=\mathrm{N}_{\mathrm{D}}^{\prime}+\Delta \mathrm{N}_{\mathrm{D}}(\mu)_{\mathrm{i}}+\mathrm{r}\left[\Delta \mathrm{N}_{\mathrm{D}}(\mu)_{\mathrm{f}}-\Delta \mathrm{N}_{\mathrm{D}}(\mu)_{\mathrm{i}}\right]
\end{aligned}
$$

where $r$ is the fraction of time that has elapsed for the particular ozone observation since April 1, 1979, within the time interval under consideration.

The following numerical example illustrates the procedures described above for final data processing:

(a) We consider an AD-DSGQP observation made at Nashville, Tennessee, June 15, 1980, at $20 \mathrm{~h}$ oom oos UT $(\mu=1.171)$. The observation yielded mean $R_{A}=112.0^{\circ}$ and mean $R D=57.2^{\circ}$. From the wedge density tables dated september 9, 1975 (Apendix 2.E) we obtain, corresponding to these instrument dial readings, $100 G_{A}=110.5$ and $100 G_{D}=56.0$. But from the August 24, 1981, wedge density tables (Appendix 2.E) we obtain $100 \mathrm{G}_{\mathrm{A}}=108.7$ and $100 \mathrm{G}_{\mathrm{D}}=55.3$. Now the time interval September 9, 1975-June 15, 1980, comprises 0.799 of the overall time interval (September 9, 1975-August 24, 1981) under consideration. Therefore, by linear interpolation, $G$ values corresponding to the $A D-D S G Q P$ observational $R$ values are $100 G_{A}=109.1$ and $100 G_{D}=55.4$. 
(b) Standard lamp tests were performed on instrument 79 at Nashville with lamps $79 \mathrm{C}$ on May 30,1980 , giving $R_{A s}$ and $R_{D S}$ values of $47.6^{\circ}$ and $53.4^{\circ}$, respectively; and on June 25 , 1980 , giving $R_{A s}$ and $R_{D S}$ values of $47.9^{\circ}$ and $53.5^{\circ}$, respectively. By linear interpolation, we take the standard lamp readings to be $R_{A s}=47.8^{\circ}$ and $R_{D S}=53.5^{\circ}$ on June 15 , 1980. From the september 9, 1975-August 24, 1981, G tables, corresponding G-values are found by Iinear interpolation to be $100 G_{A S}=47.8$ and $100 G_{D S}=51.9$ on June 15,1980 . Standard lamp $79 \mathrm{C} N$-values are $100 \mathrm{~N}_{A S}=22.3$ and $100 \mathrm{~N}_{\mathrm{DS}}=$ 25.4 (Appendix 2.E).

(c) Using relations (13) and (14) we obtain for the AD-DSGQP observation of June 15,1980

$$
\begin{aligned}
& \mathrm{N}_{\mathrm{A}}^{\prime}=1.091+(0.223-0.478)=0.836 \\
& \mathrm{~N}_{\mathrm{D}}^{\prime}=0.554+(0.254-0.519)=0.289
\end{aligned}
$$

Incorporated into the $N^{\prime}$ values are corrections for instrument 79 optical wedge density drift, but not corrections for instrument 79 spectral characteristics change due to cobalt filter deterioration, including $\mu-$ dependent corrections.

(d) To correct the observational data for the additional instrument spectral characteristics changes, we begin by evaluating relations $(17)-(20)$ above (see Appendix 2. E) for $\mu=1.171$

$$
\begin{aligned}
& 100 \Delta \mathrm{N}_{A}(\mu)_{i}=-24.5148+0.8356(1.171)+23.03=-0.506 \\
& 100 \Delta \mathrm{N}_{\mathrm{D}}(\mu)_{i}=-26.5822+0.5610(1.171)+25.59=-0.335 \\
& 100 \Delta \mathrm{N}_{A}(\mu)_{f}=-3.4037+1.2064(1.171)=-1.991 \\
& 100 \Delta \mathrm{N}_{\mathrm{D}}(\mu)_{f}=-0.5166+0.2543(1.171)=-0.219
\end{aligned}
$$

(Note that had the ozone observation been made prior to April 1, 1979, only relations (17) and (18) would have had to have been evaluated.)

For the observations made June 15,1980 , the fraction of time, $r$, elapsed since April 1, 1979, within the time interval April 1, 1979-August 14, 1981, is 0.509. Final, corrected $\mathrm{N}$-values for this ozone observation are then computed from (23) and (24):

$N_{A}=0.836-0.005+0.509(-0.020+0.005)=0.823$ 


$$
N_{D}=0.289-0.003+0.509(-0.002+0.003)=0.287
$$

(e) Total ozone amount for the observation, using vigroux ozone absorption coefficients, is then

$$
X_{A D}=1000\left[\frac{0.823-0.287}{1.388(1.171)}-0.009\right]=321 \mathrm{DU}
$$

As in section 2.4, a variation of the data reprocessing described above, yielding equivalent results, would involve direct use of $\mu$-dependent $G$ tables. Such a procedure may be more adaptable to use with existing Dobson instrument data processing software than that described.

The optical wedge of Dobson instrument 79 was manufactured by $R$. and J. Beck, Ltd., of Oxford, England. Canada balsam cement was used in gluing the wedge sections together. Over the years, experience has shown that the cement in such wedges ages with time, causing optical densities along the wedge to change. Many of the Dobson instruments in the global network have been retrofitted with "air-space" wedges from which the cement has been removed [Komhyr and Grass, 1972]. Such wedges are inherently more stable. Nevertheless, their optical characteristics may still change with time should they become contaminated; for example, with lubricant from the optical wedge track or from the instrument optical shutter bearing.

The example presented in this section of Dobson instrument performance degradation due to cobalt filter corrosion by humid air attests to the importance of keeping the Dobson instrument optics clean and dry at all times.

\subsection{Air Mass Dependence of Ozone Measurements in Polluted Air}

An important source of ozone measurement error is stray light interference, particularly at the shorter wavelength of the Dobson spectrophotometer A-wavelength pair. stray light is radiation scattered by the atmosphere in the instrument's field of view, as well as unwanted radiation scattered within the instrument. The stray light effect varies among Dobson instruments [Olafson and Asbridge, 1981; Basher, 1982], significantly limiting the accuracy of $A D$ wavelength direct sun observations at air mass $(\mu)$ values above 2.5 to 3 . G.M.B. Dobson [Walshaw, 1975] examined both sources of stray light, describing a detailed investigation of errors in ozone measurements made at low sun. Basher (1982) modeled instrumental and atmospheric factors influencing stray light, including the effect of ozone amount variations. Degorska and Rajewska-Wiech 
[1989] showed that the stray light is influenced by local pollution--a topic that is the focus of this section. One of the methods of testing a spectrophotometer for stray light is to take a series of observations on the rising or setting sun and compare results with the stray light model of Basher [1982]. A parameter of Basher's heterochromatic stray light model is $R_{0}$ which depends inversely on the quality of the instrument stray light rejection preoperties. Values of $R_{0}$ were estimated to range from $10^{-5}$ to $10^{-3}$. Values of a second model parameter, a, representing the atmosphere relative attenuation of the stray light band, range from about 0.7 to 1.2 depending on ozone amount.

Figure 2 shows two sets of $\mu$-dependent ozone data obtained with Dobson instrument 84: at Belsk, Poland in 1981 in polluted air, and at Arosa, Switzerland in 1986 in clean air. Note that in polluted air in Belsk, measured ozone decreased rapidly at $\mu$ values greater than 2.5. At Arosa, in clean air, significant decrease in ozone began at $\mu$ greater than 3.5 .

The observational data in Figure 2 have been fitted with Basher model curves having the same $R_{0}$ values for both days, but different values of a $(1.2$ and 0.7$)$. Differences in the shapes of the curves, stemming from use of the different parameters a, cannot be attributed to ozone amount differences, since ozone on both days was nearly the same $(-305 \mathrm{DU})$. Thus the differences must stem from pollution effects.

In re-evaluating Dobson instrument total ozone data, it is important to know that atmospheric pollution (including turbidity) adversely affect ozone measurements at the higher $\mu$ values. Unless ozone data from series of observations at extended $\mu$ values exist for a particular station, correction for pollution effects will be difficult to make. New measurements can provide data that may be useful in assessing errors in observations made in the past. Where possible, data selected for archiving, as representative of local apparent noon, should be restricted to observations made at $1.3<\mu<2$, since stray 1 ight and other instrumental problems tend to degrade, also ozone measurements at low $\mu$.

\subsection{CD-Tavelength Observations on Direct sun}

$A D-D S G Q P$ observations are fundamental; data from all other kinds of observations must ultimately be reduced to their calibration level. But as noted in the previous section, stray light errors, due either to instrumental factors or to sky conditions, degrade the quality of the AD-DSGQP observations at $\mu$ values larger than 2.5 to 3 .

Instrumental stray light effects are less severe for the longer wavelength and more intense CD-DSGQP observations. In relatively clean atmospheres, these observations can be extended to $\mu$ values

$$
\text { II - } 19
$$



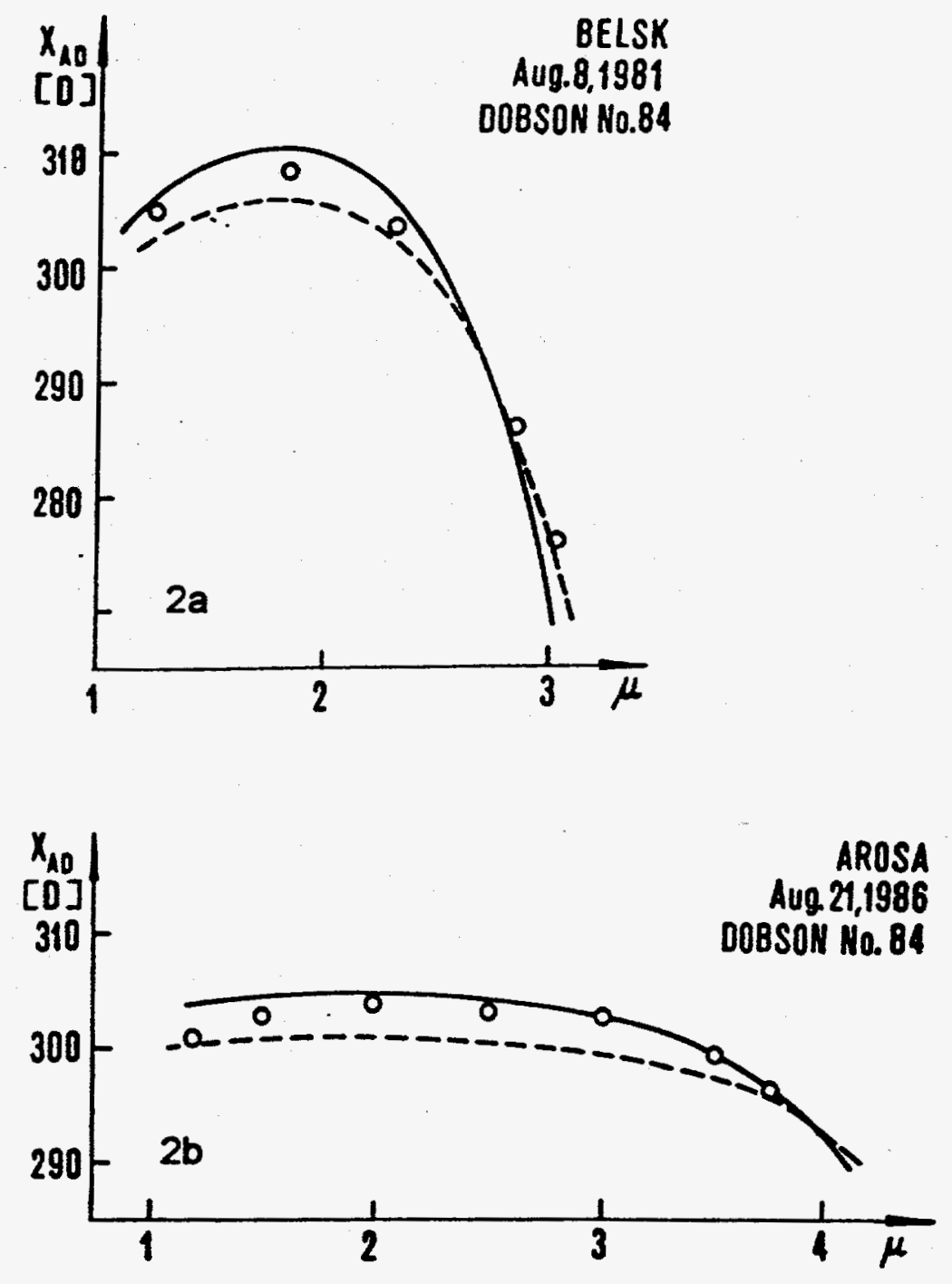

Figure 2. (a) Comparison of experimental data with stray light model: $\mathbf{R}_{\circ}=10^{-3.8},---\mathbf{R}_{\mathrm{o}}=10^{-4.0}$, $a=1.2$. (b) As in (a), but for $a=0.7$. 
of 3.5 to 4.0. Nevertheless, because relative intensity

differences for $C$ and $D$ wavelengths are considerably smaller than for $A$ and $D$ wavelengths, it is more difficult to calibrate and maintain in calibration a Dobson instrument at $C D$ wavelengths. For stations at latitudes that must resort to $C D$ type direct sun observations during certain times of the year, then, it is necessary to maintain an ongoing program of comparison AD-DSGQP and CD-DSGQP observations. These should be made in the $\mu$-range 1.5 to 2.5 or 3 , depending on the optical condition of the instrument, sky turbidity, and total ozone amount. In final data processing, ratios of the comparison total ozone amounts, plotted as a function of $\mu$, should be used in correcting the CD-DSGQP observations data.

$A D-D S F I$ and CD-DSFI ozone measurements can be made in the $\mu$ intervals 2.5-4.0 and 2.5-6.0, respectively [Komhyr, 1980], extending the $\mu$-range of Dobson spectrophotometer direct sun observations. This is possible because focused image observations reduce the amount of skylight entering the instrument and at the same time increase the intensity of the direct solar radiation entering the instrument. correction procedures for both skylight and scattered light, when the focused image method is used, have been described by Hamilton [1964]. Focused image observations are, however, difficult to make requiring considerable skill by the observer. S.H.H. Larsen, University of Oslo, Norway, has adapted the methodology of Hamilton [1964] to C-DSGQP and CD-DSGQP observations which are considerably easier to make (see Appendix 2.F). Under good observing conditions, ozone measurements can be extended by this method to $\mu$ values as high as 8 . Such observations are useful especially in late fall and early spring at high latitudes when solar elevation is low during the day.

\subsection{Use of Empirically Established Charts for Processing zenith sky Observations}

Zenith-sky observational data are reduced by means of empirically constructed charts that relate instrument $N$-values, $\mu$, and total ozone, $x$. Such charts are drawn up using quasi-simultaneously obtained data from AD-DSGQP observations and observations on the clear or cloudy zenith. Nearly simultaneous direct sun and clear zenith sky observations are readily obtainable. However, when the sky is cloudy, it often becomes necessary to compare direct sun and cloudy zenith observations that have been made several hours apart.

Charts for reducing ozone measurement data from zenith sky observations, derived from observations made at oxford, England [Dobson, 1957], were available in the past from the manufacturer of the Dobson instruments (R.J. Beck, Ltd.). Another set of charts has been published in wMo Report No. 6 [Romhyr, 1980]. They were devised in the late 1950 s and early 1960 s from

$$
I I-21
$$


observations made at Edmonton and Moosonee, Canada [Kinisky, 1961; Komhyr, 1961]. It is important to note that these charts cannot be used universally since the shapes of the chart curves are a function of the ozone vertical distribution, earth albedo, atmospheric clarity, and instrumental factors. Therefore, although the charts serve as useful starting tools for

preliminary reduction of data, it is necessary at each station to obtain a sufficient number of comparison direct sun and zenithsky observations to correct the charts so that they yield optimum quality data for that location.

An interesting variation of the standard method employed in constructing the zenith sky charts has been described by Hassan [1982] who used a multiple linear regression technique involving pair $X_{A D}^{D S}$ and $N_{\lambda \lambda}^{Z B}$ observations to construct sky charts for Cairo, Egypt. More work is needed, however, to ascertain whether such charts can be used successfully at higher latitude stations.

Zenith sky charts can also be derived from theoretical calculations based on multiple scattering in a purely molecular atmosphere [Mateer et al., 1977]. Such calculations take into account standard or climatological ozone profiles, the effect of temperature on ozone absorption coefficients, and ground albedo. stamnes et al. [1990] used a comprehensive radiative transfer algorithm to draw zenith sky charts. The method allows taking into consideration atmospheric optical depth and cloud height as well. Such theoretically derived charts, however, need on-site correcting to account for modelling uncertainties and instrumental factors.

Final processing of ozone observations made on zenith sky should be performed with corrected and re-drawn charts. An alternative procedure is to determine corrections; for example, to the charts provided in WMO Report No. 6 , by plotting AD-DSGQP versus ADZB, $A D Z C, C C^{\prime} Z B, C C^{\prime} Z C, C D Z B, C D Z C$ observations as a function of $\mu$. As an example, such corrections for ADZB type observations, determined at Bismarck from measurements made during 1962 to 1985, are shown in Figure 3. Ideally, such plots should be made for low, medium, and high values of ozone. Figure 4 shows similar comparison data for $A D$ wavelength zenith cloud observations. Here the scatter in the data is considerably greater since the comparison observations were often made several hours apart during which time significant changes in ozone sometimes occurred. Cloud observations are, also, inherently less precise than are the clear zenith observations.

We have strong indication from Umkehr observations that stratospheric aerosols from occasional volcanic eruptions influence UV flux ratios emanating downward from the zenith sky at the $A, C$, and $D$ Dobson instrument wavelength pairs. The extent to which these aerosols affect total ozone data derived from zenith sky observations requires further study.

$$
I I-22
$$




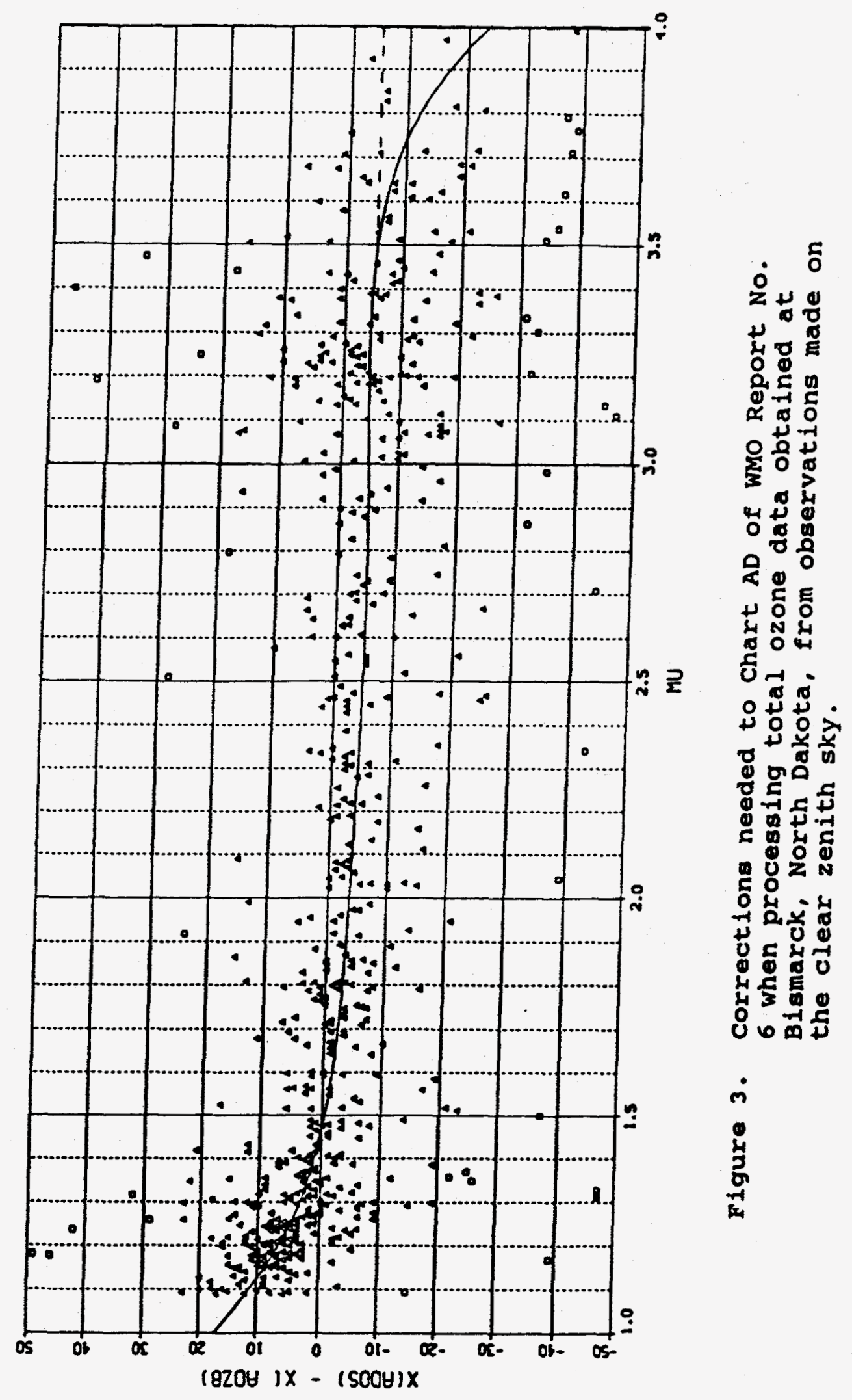




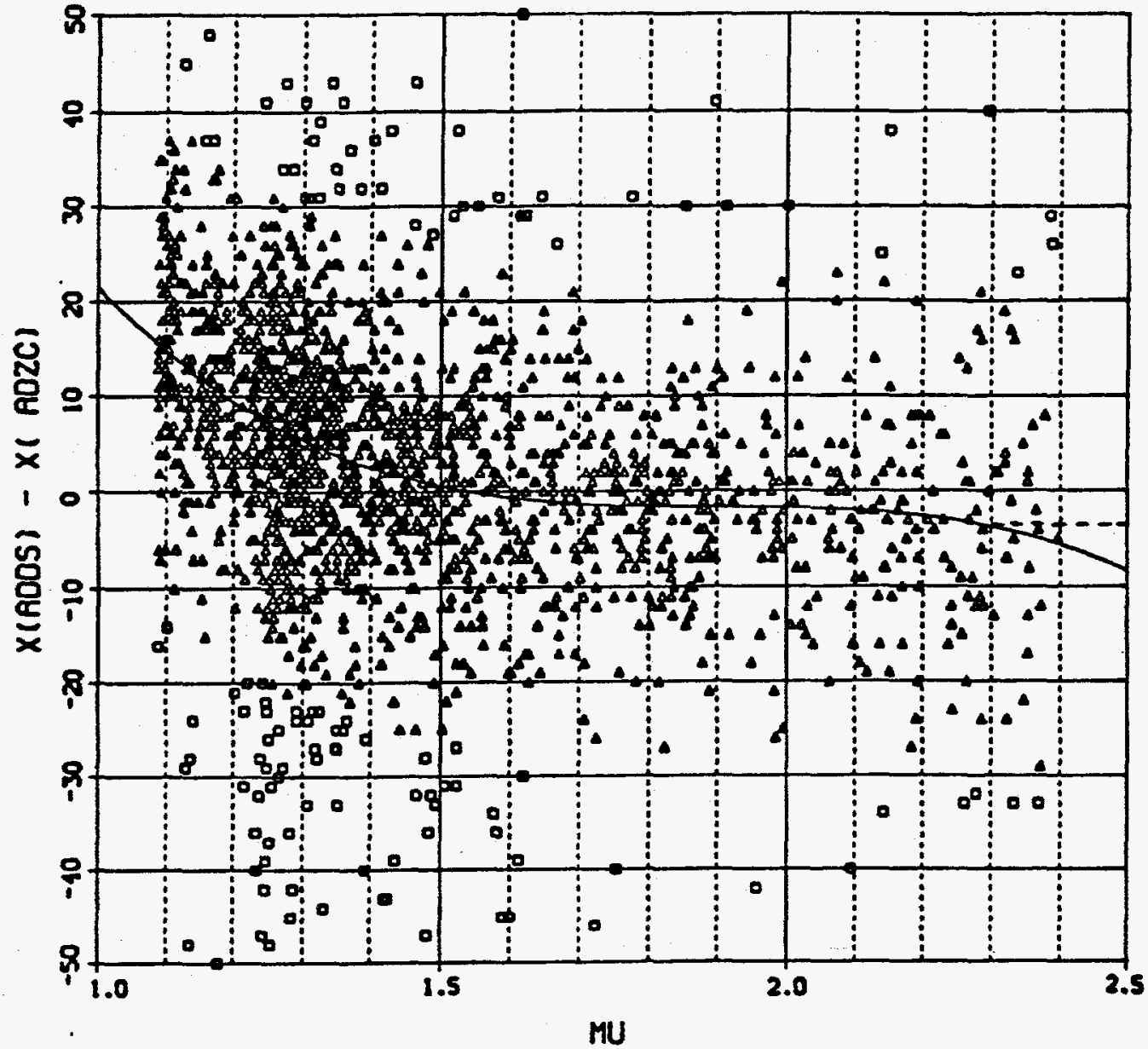

Figure 4. Corrections needed to Chart AD of WMO Report No. 6 for processing total ozone data at Bismarck, North Dakota, from observations made on the cloudy zenith sky.

Special attention is called to chart $\mathrm{N}_{c}$ used in reducing $\mathrm{CC} \mathrm{zC}$ observations. The abscissa values for this chart are fixed by setting the $\Delta N=0$ correction curve at the extreme right of plotted $\mathrm{N}_{\mathrm{C}}$ values derived from observations on the blue sky. This is shown, for example, in Figure 5, for observations made a Bismarck during June 2, 1976-May 28, 1980. Should similar observational data not be available for the following severalyear observing interval beginning May 29, 1980, for which new reference $N$ tables and standard lamp readings are established for routine total ozone data reduction, the $\mathrm{N}_{C}$ chart derived from the 1976-1980 observations can continue to be used beyond May 28, 


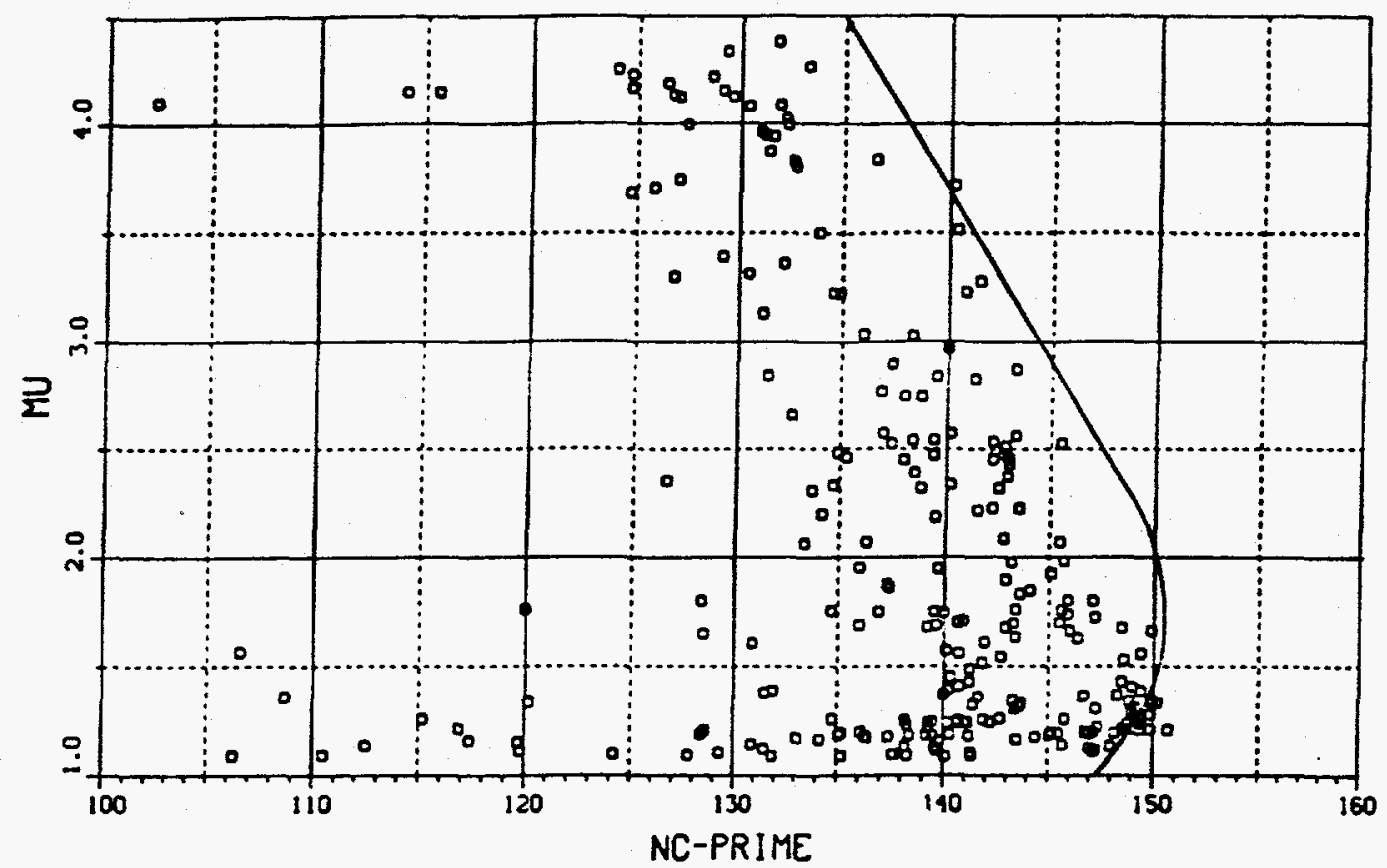

Figure 5. Illustration, from observations made at Bismarck during June 1976-May 1980, of the method of fixing the abscissa value of the $\Delta \mathrm{N}=0$ curve of the cloud correction Chart $C^{\prime}$ given in WMO Report No. 6.

1980. However, before using it, it is first necessary to shift the $\Delta N=0$ curve of Figure 4 horizontally by the difference in reference standard lamp $N_{C}$ readings for the June 2, 1976, and May 29, 1980, instrument calibrations. For example, as shown in Figure 5, the abscissa value for the curve $\Delta \mathrm{N}_{c}=0$ at $\mu=1$ is $100 \mathrm{~N}_{C^{\prime}}=147$. If the reference standard lamp $\mathrm{N}_{C^{\prime}}$ values for the instrument in-the-mean are larger on May 29, 1980, by $6100 \mathrm{~N}$ units than they were June 2,1976 , the curve should be shifted to read $100 N_{c}=147+6=153$ at $\mu=1$. The need for this shift arises because Dobson spectrophotometer calibrations relative to a standard are performed at $A, C$, and $D$ wavelengths, but not $C$ ' wavelengths, and $\mathrm{N}_{c}$ values are obtained from $\mathrm{N}_{c}$ tables.

The above technique may be used also when a replacement spectrophotometer, for which an $N_{C}$ chart has not been established observationally, is temporarily used at a station. 


\subsection{Total Ozone Measurement Interfering Absorbing species}

Komhyr and Evans [1980] identified a number of trace gas species that possess absorption spectra in the spectral region of the Dobson instrument wavelengths. Of these, $\mathrm{SO}_{2}$ and $\mathrm{NO}_{2}$ have the greatest potential for causing Dobson instrument total ozone measurement errors. De Backer and De Muer [1991] and De Muer and De Backer [1992] have shown that in certain regions of the globe $\mathrm{SO}_{2}$ pollution may also have a significant effect on the determination of ozone trends.

Although $\mathrm{SO}_{2}$ measurements are possible with a Dobson spectrophotometer, such observations are seldom made. Near ground-level $\mathrm{SO}_{2}$ data are available in some locations from pollution monitoring networks; however, translating surface $\mathrm{SO}_{2}$ concentrations to atmospheric total column $\mathrm{SO}_{2}$ entails considerable research that is best reserved for special studies, with formal publication of results obtained in the open literature. Thus, re-evaluation of Dobson instrument data should, in general, not include correcting the data for $\mathrm{SO}_{2}$ interference or other interfering absorbing species.

An exception exists where a Dobson instrument observatory is located fairly close to a coal- or oil-fired power plant. on occasion when the observatory is downwind from the plume, measured ozone values may be too high by $10 \%$ or more. Successive ozone observations made under such conditions generally yield erratic data with a large standard deviation associated with the mean. Such data, if included in the ozone daily means archive, should be flagged as most likely being unreliable.

(For reasons given above, the re-evaluated Dobson instrument data should, also, not be corrected for changes in effective Dobson instrument ozone absorption coefficients that vary seasonally or on a secular basis as stratospheric temperatures change.)

\subsection{Calibration of Dobson spectrophotometers With Calibrated Traveling standard Lamps}

At the 1977 International Comparison of Dobson Ozone Spectrophotometers held in Boulder, colorado, a traveling standard lamp method was devised [Komhyr et al., 1981] for identifying Dobson instruments that have gross calibration errors. (Traveling standard lamps are calibrated with World Primary standard Dobson spectrophotometer 83 ). Tests on 14 instruments at that time, well calibrated on a relative scale (i.e., newly optically aligned, and with high quality wavelength-setting and optical wedge calibrations), showed that such instruments can be calibrated with lamps to yield ozone measurement uncertainties at the $95 \%$ interval confidence level of $2.2 \%, 1.1 \%$, and $0.7 \%$ when measuring 300 DU ozone at air mass values of 1,2 , and 3 , 
respectively. (These errors are about twice as large as those ass uciated with direct spectrophotometer intercalibrations.) Subsequently, seven standard lamp units were built and calibrated, each consisting of two calibrated lamps and a stable power supply. The global Dobson instrument network was then divided into seven areas, each containing from 5 to 17 instruments, and a lamp unit was shipped to each area for use in checking the calibrations of the Dobson instruments in that area. Results of the first round robin of such calibrations, conducted in 1981-1983 [Grass and Komhyr, 1985], showed that 21 of the 78 instruments tested needed re-calibration, with 17 instruments having large calibration errors of 3-10\%. A second series of tests in 1985-1987 involving 81 instruments [Grass and Romhyr, 1989] showed that 13 needed re-calibration, with 5 instruments having calibration errors as large as 3-5\%. A third such Dobson instrument test series, initiated in 1990, is nearing completion.

The main purpose of the traveling standard lamp tests has not been to calibrate Dobson instruments, but to check on how well they are calibrated. Such calibrations, however, can be useful when performed on instruments that are well aligned optically and have high quality wavelength-setting and optical wedge calibrations. Large calibration errors can ensue, however, for instruments that have poor, not well known, optical

characteristics. Total ozone data re-evaluations for such

instruments should not be based on calibrations of the instruments with traveling standard lamps.

\section{Acknowl edgments}

Appreciation is expressed to M. Degórska and B. Rajewska-Wiech of the Polish Academy of Sciences; D. DeMuer of the Royal Meteorological Institute of Belgium; and S.H.H. Larsen, University of oslo in Norway for contributions to portions of the Handbook. Helpful comments and criticisms were provided also by $\mathrm{J}$. Easson of the Australian Bureau of Meteorology; A. Frolov and A. Shalamiansky of the Main Geophysical Observatory in St. Petersburg, Russia; and G.K.Y Hassan of the Eqyptian Meteorological Authority in Cairo.

\subsection{References}

Basher, R.E., Review of the Dobson spectrophotometer and its accuracy, Rep. 13, WMO Global Ozone Research and Monitoring Project, Geneva, 1982 .

Bass, A.M. and R.J. Paur, The ultraviolet cross-sections of ozone, I. The Measurements, in Atmospheric Ozone, edited by C.S. Zerefos and A. Ghazi, pp. 606-610, Reidel, Dordrecht, Boston, Lancaster, 1985. 
De Backer, H. and D. De Muer, Intercomparison of total ozone data measured with Dobson and Brewer ozone spectrophotometers at Uccle (Belgium) from January 1984 to March 1991, including zenith sky observations, J. Geophys. Res., 97, 20,711$20,719,1992$.

Degorska, M. and B. Rajewska-Wiech, The effect of stray light on total ozone measurements at Belsk, Poland, in Ozone in the Atmosphere, Proc. Quadr. Ozone Symp. 1988 and Tropospheric Ozone Workshop, ed. R.D. Bojkov and P. Fabian, A. Deepak Publishing 1989, Hampton, Virginia, 759-761, 1989.

De Muer, D. and $H$. De Backer, Revision of 20 years of Dobson total ozone data at Uccle (Belgium); Fictitious Dobson total ozone trends induced by sulfur dioxide trends, $J$. Geophys. Res., 97, 5921-5937, 1992.

Dobson, G.M.B., Observers' handbook for the ozone spectrophotometer, Ann. Int. Geophys. Year, 5, part 1, 46-89, 1957.

Grass, R.D. and W.D. Komhyr, Traveling standard lamp calibration checks on Dobson ozone spectrophotometers during 1981-83, in Atmospheric Ozone, Proc. Quadrennial Ozone Symposium, Halkidiki, Greece, September 3-7, 1984, ed. C.S. Zerefos and A. Ghazi, pp. 376-380, Reidel, Dordrecht, 1985.

Grass, R.D. and W.D. Komhyr, Traveling standard lamps calibration checks of Dobson ozone spectrophotometers during 1985-1987, Ozone in the Atmosphere, Proc. Quadrennial Ozone symposium 1988 and Tropospheric Ozone Workshop, R.D. Bojkov and P. Fabian, Eds., pp. 144-146, A Deepak, Hampton, VA, 1989.

Hamilton, R.A., Determination of ozone amounts by the Dobson spectrophotometer using the focused sun method, Q.J. Roy. Met. Soc., 90, 333-337, 1964.

Hassan, G.K.Y., Construction of empirical zenith ozone charts and tables using the multiple regression technique, in Atmospheric Ozone, Proc. Quadrennial ozone symposium, Halkidiki, Greece, 3-7 September 1984, ed. C.S. Zerefos and A. Ghazi, pp. 532-542, Reidel, Dordrecht, 1985.

Hudson, R.D., W.D. Komhyr, C.L. Mateer, and R.D. Bojkov, Guidance for use of new ozone absorption coefficients in processing Dobson and Brewer spectrophotometer total ozone data beginning 1 January, 1992, WMO document RDP-825, December $18,1991$.

Kinisky, J.J., W.D. Komhyr, and C.L. Mateer, Measurements of atmospheric ozone at Edmonton, Canada - July 1, 1957 to June 30, 1960, Canadian Meteorological Memoirs, No. 8, Dept. Transport, Met. Branch, Toronto, 90 pp., 1961. 
Komhyr, w.D., Measurements of atmospheric ozone at Moosonee, Ca.lada - July 1, 1957 to July 31, 1960, Canadian

Meteorological Memoirs, No. 6, Dept. Transport, Met. Branch, Toronto, 96 pp., 1961.

Komhyr, W.D., Operations handbook - ozone observations with a Dobson spectrophotometer, Rep. 6, WMO Global Ozone Res. and Monit. Proj., Geneva, 1980.

Komhyr, W.D. and R.D. Evans, Dobson spectrophotometer total ozone measurement errors caused by interfering absorbing species such as $\mathrm{SO}_{2}, \mathrm{NO}_{2}$, and photochemically produced $\mathrm{O}_{3}$ in polluted air, Geophys. Res. Lett., 7, 157-160, 1980.

Komhyr, W.D., R.D. Grass, and R.K. Leonard, Dobson spectrophotometer 83: A standard for total ozone measurements 1962-1987, J. Geophys. Res., 94(D7). 9847-9861, 1989.

Komhyr, W.D., C.L. Mateer, and R.D. Hudson, Effective Bass-Paur 1985 ozone absorption coefficients for use with Dobson ozone spectrophotometers, J. Geophys. Res, (in press) 1993.

Mateer, C.L., I.A. Asbridge, and R.A. Olafson, Comparison of Dobson spectrophotometer observations of polarized skylight with theoretical calculations, in Proceedings of the Joint Symposium on Atmospheric Ozone, 9-17 August 1976, ed. K.H. Grasnick, Dresden, G.D.R., 89-99. 1977.

Olafson, R.A. and I.A. Asbridge, Stray light in Dobson spectrophotometer and its effect on ozone measurements, Proc. 1980 Quad. Int. Ozone Symp., ed. J. London, Boulder, Colorado, vol. 1, 46-47, 1981.

Stamnes, R., S. Pegau, and J. Fredrick, Uncertainties in total ozone amounts inferred from zenith sky observations: Implications for ozone trend analysis, $J$. Geophys. Res, $95(D 10), 16,523-16,528,1990$.

Vigroux, E., Contribution à l'étude expérimentale de l'absorption de l'ozone, Ann. Phys. 8, 709-762, 1953.

Vigroux, E., Détermination des coefficients moyens d'absorption de l'ozone en vue des observations concernant l'ozone atmosphérique a l'aide due spectromètre Dobson, Ann. Phys., $2,209-215,1967$.

Walshaw, C.D. (ed), Papers of Professor G.M.B. Dobson FRS, Publs. Inst. Geophys. Pol. Acad. Sc., 89, 61-115, 1975. 
World Meteorological Organization (WMO), Consultation on Brewer ozone spectrophotometer operation, calibration, and data reporting (Arosa, Switzerland, 2-4 August 1990), Rep. 22, WMO Global Ozone Res. and Monit. Proj., Geneva, 1991. 


\section{APPENDIX 2.A}

CALIBRATION SCALES - WORLD PRIMARY STANDARD DOBSON SPECTROPHOTOMETER 83 
NTables

183 JUNE $18,1962 F 1$

$\begin{array}{lcrrrrrr}R & 0 & 50^{\circ} & 100^{\circ} & 150^{\circ} & 200^{\circ} & 250^{\circ} & 290^{\circ} \\ N_{A} & -0.103 & 0.419 & 0.889 & 1.368 & 1.855 & 2.359 & 2.770 \\ N_{C} & -0.072 & 0.446 & 0.913 & 1.386 & 1.869 & 2.367 & 2.774 \\ N_{D} & -0.059 & 0.454 & 0.920 & 1.389 & 1.866 & 2.359 & 2.761\end{array}$

e-Setting Table Applicable at sterling Virginia

At $15^{\circ} \mathrm{C}: Q_{A}=49.05^{\circ} \quad Q_{C}=76.30^{\circ} \quad Q_{D}=107.40^{\circ}$ $Q_{\mathrm{Hg}-312.9}=84.05^{\circ}$

Temp. Coeff. $\mathrm{Hg}-312.9 \mathrm{~nm}: 0.125^{\circ} \mathrm{Q} /{ }^{\circ} \mathrm{C}$

Reference Standard Lamp Readings.

$\begin{array}{lllllll}\text { Lamp No. } & R_{A}\left({ }^{\circ}\right) & N_{A} & R_{C}\left({ }^{\circ}\right) & N_{C} & R_{D}\left(^{\circ}\right) & N_{D} \\ 83 A & 28.0 & 0.198 & 28.5 & 0.231 & 28.1 & 0.238 \\ 83 \mathrm{~B} & 28.3 & 0.201 & 28.8 & 0.234 & 28.3 & 0.240 \\ W & 26.9 & 0.187 & 27.9 & 0.225 & 27.7 & 0.234 \\ \text { X } & 32.9 & 0.248 & 31.8 & 0.265 & 30.3 & 0.260 \\ Y & 30.7 & 0.226 & 30.1 & 0.247 & 29.0 & 0.247 \\ Z & 27.0 & 0.188 & 27.6 & 0.222 & 27.4 & 0.230\end{array}$




\section{$\$ 83$ JUNE 26, 1972FI}

Nables

$\begin{array}{lcrrrrrr}R & 00^{\circ} & 50^{\circ} & 100^{\circ} & 150^{\circ} & 200^{\circ} & 250^{\circ} & 290^{\circ} \\ N_{\lambda} & -0.092 & 0.424 & 0.893 & 1.369 & 1.861 & 2.366 & 2.775 \\ N_{C} & -0.063 & 0.452 & 0.916 & 1.387 & 1.871 & 2.370 & 2.775 \\ N_{D} & -0.047 & 0.468 & 0.929 & 1.395 & 1.874 & 2.368 & 2.767\end{array}$

Q-Setting Table Applicable at MLO At $15^{\circ} \mathrm{C}: \quad \begin{aligned} & Q_{\mathrm{A}}=47.30^{\circ} \quad Q_{\mathrm{C}}=73.65^{\circ} \quad Q_{\mathrm{D}}=104.85^{\circ} \\ & Q_{\mathrm{Hg}-312.9}=81.30^{\circ}\end{aligned}$

Temp. Coeff. $\mathrm{Hg}-312.9 \mathrm{~nm}: 0.125^{\circ} \mathrm{Q} /{ }^{\circ} \mathrm{C}$

Reference standard Lamp Readings

$\begin{array}{lllllll}\text { Lamp No. } & R_{A}\left({ }^{\circ}\right) & N_{A} & R_{C}\left({ }^{\circ}\right) & N_{C} & R_{D}\left(^{\circ}\right) & N_{D} \\ \text { 83A } & 28.5 & 0.209 & 28.7 & 0.240 & 28.3 & 0.252 \\ \text { 83B } & 28.8 & 0.212 & 29.0 & 0.243 & 28.5 & 0.254 \\ \text { W } & 27.5 & 0.199 & 28.1 & 0.234 & 27.8 & 0.247 \\ \text { X } & 33.4 & 0.260 & 32.1 & 0.275 & 30.6 & 0.276 \\ Y & 31.3 & 0.238 & 30.5 & 0.259 & 29.4 & 0.263 \\ Z & 27.7 & 0.201 & 28.1 & 0.234 & 27.8 & 0.247\end{array}$




\section{AUGUST $26,1975 F 1$}

\section{$N$ Tables}

$\begin{array}{lcrrrrrr}R & 0 & 50^{\circ} & 100^{\circ} & 150^{\circ} & 200^{\circ} & 250^{\circ} & 290^{\circ} \\ N_{\text {A }} & -0.091 & 0.423 & 0.891 & 1.366 & 1.855 & 2.360 & 2.769 \\ N_{C} & -0.061 & 0.452 & 0.917 & 1.387 & 1.870 & 2.367 & 2.773 \\ N_{D} & -0.048 & 0.465 & 0.926 & 1.391 & 1.867 & 2.358 & 2.758\end{array}$

Q-Setting Table Applicable at MIO

At $15^{\circ} \mathrm{C}: \quad \begin{aligned} & Q_{A}=47.30^{\circ} \quad Q_{C}=73.65^{\circ} \quad Q_{D}=104.85^{\circ} \\ & Q_{H g-312.9}=81.30^{\circ}\end{aligned}$

Temp. Coeff. $\mathrm{Hg}-312.9 \mathrm{~nm}: 0.125^{\circ} \mathrm{Q} /{ }^{\circ} \mathrm{C}$

Reference standard Lamp Readings

$\begin{array}{lllllll}\text { Lamp No. } & R_{A}\left({ }^{\circ}\right) & N_{A} & R_{C}\left(^{\circ}\right) & N_{C} & R_{D}\left(^{\circ}\right) & N_{D} \\ 83 A & 28.5 & 0.210 & 28.6 & 0.241 & 28.4 & 0.252 \\ 83 B & 28.9 & 0.214 & 29.0 & 0.245 & 28.6 & 0.254 \\ W & 27.9 & 0.204 & 28.3 & 0.238 & 28.0 & 0.248 \\ X & 33.9 & 0.265 & 32.3 & 0.279 & 30.8 & 0.277 \\ Y & 31.5 & 0.241 & 30.5 & 0.261 & 29.5 & 0.264 \\ Z & 28.1 & 0.206 & 28.3 & 0.238 & 27.9 & 0.247 \\ 83 Q 1 & 20.6 & 0.127 & 22.0 & 0.172 & 22.5 & 0.191 \\ 83 Q 2 & 20.3 & 0.124 & 21.7 & 0.169 & 22.3 & 0.188 \\ 83 Q 3 & 20.0 & 0.121 & 21.5 & 0.167 & 21.9 & 0.184 \\ \text { UQ1 } & 21.4 & 0.135 & 22.8 & 0.180 & 23.4 & 0.200 \\ \text { UQ2 } & 21.1 & 0.132 & 22.5 & 0.177 & 23.0 & 0.196 \\ \text { UQ4 } & 20.3 & 0.124 & 21.5 & 0.167 & 22.2 & 0.187\end{array}$


83 JULY 10,1987 FI

N Tables

$\begin{array}{lcrrrrrr}R & 0^{\circ} & 50^{\circ} & 100^{\circ} & 150^{\circ} & 200^{\circ} & 250^{\circ} & 290^{\circ} \\ \mathrm{N}_{\text {A }} & -0.058 & 0.459 & 0.928 & 1.403 & 1.891 & 2.396 & 2.805 \\ \mathrm{~N}_{B} & -0.132 & 0.383 & 0.851 & 1.321 & 1.805 & 2.307 & 2.713 \\ \mathrm{~N}_{C} & -0.023 & 0.491 & 0.955 & 1.422 & 1.901 & 2.400 & 2.803 \\ \mathrm{~N}_{D} & -0.005 & 0.506 & 0.968 & 1.431 & 1.906 & 2.400 & 2.800\end{array}$

e-Setting Table Applicable at MLO

At $15^{\circ} \mathrm{C}: \quad \begin{array}{ll}Q_{A}=47.85^{\circ} & Q_{B}=61.45 \quad Q_{C}=74.45^{\circ} \\ Q_{D}=105.40^{\circ} & Q_{\mathrm{Hg}-312.9}=82.10^{\circ}\end{array}$

Temp. Coeff. $\mathrm{Hg}-312.9 \mathrm{~nm}: 0.125^{\circ} \mathrm{Q} /{ }^{\circ} \mathrm{C}$

Reference Standard Lamp Readings

$\begin{array}{lllllllll}\text { Lamp } & R_{A}\left({ }^{\circ}\right) & N_{A} & R_{B}\left({ }^{\circ}\right) & N_{B} & R_{C}\left(^{\circ}\right) & N_{C} & R_{D}\left(^{\circ}\right) & N_{D} \\ \text { No. } & & & & & & & & \\ 83 Q I & 16.9 & 0.124 & 17.3 & 0.054 & 18.1 & 0.170 & 18.2 & 0.188 \\ 83 Q 2 & 16.8 & 0.123 & 17.1 & 0.052 & 17.9 & 0.168 & 18.1 & 0.187 \\ 83 Q 3 & 16.4 & 0.118 & 16.7 & 0.048 & 17.6 & 0.165 & 17.7 & 0.183 \\ 83 Q 4 & 16.6 & 0.121 & & & 17.6 & 0.165 & 17.8 & 0.184 \\ 83 Q 5 & 16.4 & 0.118 & & & 17.4 & 0.163 & 17.7 & 0.183 \\ \text { UQ1 } & 17.9 & 0.134 & 18.2 & 0.063 & 19.0 & 0.179 & 19.2 & 0.198 \\ \text { UQ2 } & 17.4 & 0.129 & 17.8 & 0.059 & 18.5 & 0.174 & 18.7 & 0.193 \\ U Q 4 & 16.7 & 0.122 & 16.9 & 0.050 & 17.8 & 0.167 & 17.9 & 0.185 \\ \text { UQ5 } & 16.4 & 0.118 & & & 17.5 & 0.164 & 17.6 & 0.182 \\ 83 B & 25.4 & 0.212 & & & 25.4 & 0.246 & 24.5 & 0.254 \\ \text { W } & 24.0 & 0.198 & & & 24.4 & 0.235 & 23.5 & 0.243 \\ X & 30.4 & 0.264 & & & 28.6 & 0.279 & 26.5 & 0.274 \\ Y & 27.8 & 0.237 & & & 26.6 & 0.258 & 24.9 & 0.258 \\ Z & 24.0 & 0.198 & & & 24.3 & 0.234 & 23.1 & 0.239\end{array}$




\section{AUGUST $26,1991 F 1$}

\section{Tables}

$\begin{array}{lcrrrrrr}R & 0^{\circ} & 50^{\circ} & 100^{\circ} & 150^{\circ} & 200^{\circ} & 250^{\circ} & 290^{\circ} \\ N_{\text {A }} & -0.066 & 0.450 & 0.917 & 1.391 & 1.879 & 2.383 & 2.793 \\ N_{B} & -0.140 & 0.375 & 0.840 & 1.310 & 1.793 & 2.294 & 2.701 \\ N_{C} & -0.033 & 0.481 & 0.944 & 1.410 & 1.890 & 2.387 & 2.790 \\ N_{D} & -0.015 & 0.498 & 0.959 & 1.421 & 1.897 & 2.389 & 2.790\end{array}$

\section{o-setting Table Applicable at MLO}

At $15^{\circ} \mathrm{C}: \quad Q_{\mathrm{A}}=47.40^{\circ} \quad Q_{\mathrm{B}}=60.90^{\circ} \quad Q_{C}=73.70^{\circ}$

$$
Q_{D}=104.85^{\circ} \quad Q_{H g}-312.9=81.60^{\circ}
$$

Temp. Coeff. $\mathrm{Hg}-312.9 \mathrm{~nm}: 0.125^{\circ} \mathrm{Q} /{ }^{\circ} \mathrm{C}$

Reference standard Lamp Readings

$\begin{array}{lllllllll}\text { Lamp No. } & R_{A}\left({ }^{\circ}\right) & N_{A} & R_{B}\left({ }^{\circ}\right) & N_{B} & R_{C}\left({ }^{\circ}\right) & N_{C} & R_{D}\left({ }^{\circ}\right) & N_{D} \\ 83 Q I & 18.2 & 0.129 & 18.5 & 0.058 & 19.3 & 0.173 & 19.4 & 0.192 \\ 8303 & 17.6 & 0.123 & 18.0 & 0.052 & 18.8 & 0.168 & 18.8 & 0.186 \\ 83 Q 4 & 17.8 & 0.125 & & & 18.8 & 0.168 & 18.9 & 0.187 \\ 83 Q 5 & 17.6 & 0.123 & & & 18.6 & 0.166 & 18.8 & 0.186 \\ \text { UQ1 } & 19.1 & 0.138 & 19.5 & 0.068 & 20.2 & 0.182 & 20.2 & 0.200 \\ \text { UQ2 } & 18.7 & 0.134 & 19.0 & 0.063 & 19.7 & 0.177 & 19.8 & 0.196 \\ \text { UQ5 } & 17.6 & 0.123 & & & 18.7 & 0.167 & 18.7 & 0.185\end{array}$




\section{APPENDIX 2.B}

CALIBRATION SCALES - SECONDARY STANDARD DOBSON SPECTROPHOTOMETER 65 
N Tables

65 APRIL $10,1981 E 1$

$\begin{array}{lcrrrrrr}R & 0 & 50^{\circ} & 100^{\circ} & 150^{\circ} & 200^{\circ} & 250^{\circ} & 290^{\circ} \\ N_{A} & -0.172 & 0.364 & 0.855 & 1.363 & 1.904 & 2.438 & 2.884 \\ N_{C} & -0.118 & 0.417 & 0.906 & 1.407 & 1.942 & 2.469 & 2.911 \\ N_{D} & -0.101 & 0.433 & 0.920 & 1.418 & 1.948 & 2.472 & 2.911\end{array}$

o-Setting Table Applicable in Boulder, colorado

At $15^{\circ} \mathrm{C}: Q_{\mathrm{A}}=48.50^{\circ} \quad Q_{\mathrm{C}}=75.30^{\circ} \quad Q_{\mathrm{D}}=106.45^{\circ}$

$$
Q_{\mathrm{Kg}-312.9}=83.10^{\circ}
$$

Temp. Coeff. $\mathrm{Hg}-312.9 \mathrm{~nm}: 0.125^{\circ} \mathrm{Q} /{ }^{\circ} \mathrm{C}$

Reference Standard Lamp Readings

$\begin{array}{lllllll}\text { Lamp No. } & R_{A}\left({ }^{\circ}\right) & N_{\lambda} & R_{C}\left({ }^{0}\right) & N_{C} & R_{D}\left({ }^{\circ}\right) & N_{D} \\ 65 Q 1 & 25.6 & 0.111 & 25.5 & 0.165 & 25.7 & 0.183 \\ 65 Q 2 & 26.5 & 0.121 & 26.6 & 0.177 & 26.7 & 0.194 \\ 65 Q 3 & 26.1 & 0.116 & 26.3 & 0.173 & 26.5 & 0.192 \\ \text { UQ1 } & 27.3 & 0.129 & 27.3 & 0.188 & 27.7 & 0.205 \\ \text { UQ2 } & 27.1 & 0.127 & 27.2 & 0.183 & 27.4 & 0.201 \\ \text { UQ3 } & 26.0 & 0.115 & 26.3 & 0.173 & 26.4 & 0.190 \\ 65 Q 4 & 25.9 & 0.114 & 26.2 & 0.172 & 26.3 & 0.189 \\ 65 Q 5 & 26.0 & 0.115 & 26.2 & 0.172 & 26.4 & 0.190\end{array}$


$N$ Tables

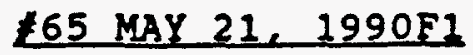

$\begin{array}{lcrrrrrr}R & 0 & 50^{\circ} & 100^{\circ} & 150^{\circ} & 200^{\circ} & 250^{\circ} & 290^{\circ} \\ N_{\lambda} & -0.168 & 0.362 & 0.850 & 1.353 & 1.892 & 2.428 & 2.868 \\ N_{C} & -0.129 & 0.402 & 0.888 & 1.384 & 1.917 & 2.446 & 2.881 \\ N_{D} & -0.110 & 0.422 & 0.906 & 1.400 & 1.930 & 2.456 & 2.888\end{array}$

e-setting Table Applicable in Boulder, colorado At $15^{\circ} \mathrm{C}: \quad \begin{aligned} & Q_{A}=48.00^{\circ} \quad Q_{C}=74.85^{\circ} \quad Q_{D}=106.10^{\circ} \\ & Q_{H g-312.9}=82.75^{\circ}\end{aligned}$

Reference Standard Lamp Readings

$\begin{array}{lllllll}\text { Lamp No. } & R_{A}\left(^{\circ}\right) & N_{A} & R_{C}\left(^{\bullet}\right) & N_{C} & R_{D}\left({ }^{\bullet}\right) & N_{D} \\ 65 Q 1 & 26.3 & 0.119 & 26.4 & 0.160 & 26.4 & 0.180 \\ 6502 & 27.1 & 0.128 & 27.3 & 0.170 & 27.3 & 0.190 \\ 6504 & 26.8 & 0.125 & 27.1 & 0.168 & 27.1 & 0.188 \\ 6505 & 26.7 & 0.124 & 27.0 & 0.167 & 27.0 & 0.187 \\ \text { UQ1 } & 28.2 & 0.139 & 28.5 & 0.183 & 28.5 & 0.202 \\ \text { UQ2 } & 27.8 & 0.135 & 28.0 & 0.177 & 28.2 & 0.199 \\ \text { UQ5 } & 26.8 & 0.125 & 27.0 & 0.167 & 27.0 & 0.187\end{array}$


N Tables

65 AUGUST $30,1991 F 1$

$\begin{array}{lcrrrrrr}R & 0^{\circ} & 50^{\circ} & 100^{\circ} & 150^{\circ} & 200^{\circ} & 250^{\circ} & 290^{\circ} \\ N_{\text {A }} & -0.172 & 0.358 & 0.849 & 1.353 & 1.893 & 2.428 & 2.870 \\ N_{C} & -0.128 & 0.405 & 0.892 & 1.390 & 1.921 & 2.449 & 2.885 \\ N_{D} & -0.117 & 0.417 & 0.902 & 1.397 & 1.925 & 2.450 & 2.882\end{array}$

Q-Setting Table Applicable in Boulder, colorado

$Q_{\mathrm{Hg}-312.9}=82.50^{\circ}$

Reference standard Lamp Readings

$\begin{array}{lllllll}\text { Lamp } & R_{A}\left({ }^{\circ}\right) & N_{A} & R_{C}\left(^{\circ}\right) & N_{C} & R_{D}\left(^{\circ}\right) & N_{D} \\ \text { No. } & & & & & & \\ 65 Q 1 & 26.5 & 0.117 & 26.7 & 0.165 & 26.7 & 0.178 \\ 65 Q 2 & 27.1 & 0.123 & 27.5 & 0.174 & 27.7 & 0.188 \\ 65 Q 4 & 27.0 & 0.122 & 27.2 & 0.170 & 27.2 & 0.183 \\ 65 Q 5 & 26.8 & 0.120 & 27.0 & 0.168 & 27.0 & 0.181 \\ \text { UQ1 } & 28.2 & 0.135 & 28.7 & 0.186 & 28.8 & 0.199 \\ \text { UQ2 } & 28.0 & 0.133 & 28.0 & 0.179 & 28.3 & 0.194 \\ \text { UQ3 } & 26.8 & 0.120 & 27.2 & 0.170 & 27.3 & 0.184\end{array}$




\section{APPENDIX 2.C}

\section{DOBSON INSTRUMENT 33 SAMPLE CALIBRATION DATA - APRIL 15, 1986 AND MAY 11, 1988}

(a) Stable optical wedge.

(b) No $\mu$-dependency for observations on $A$ and $D$ wavelengths.*

(c) A change occurred in the spectral characteristics of Dobson instrument 33 at $A, C$, and $D$ wavelengths.

*C-wavelength observations show a $\mu$-dependency. Procedures for correcting ozone data for $\mu$-dependency are described in section 2.4 . 
DOBSON OZONE SPECTROPHOTOMETER CALIBRATION

Place: Bolder, Colorado

Dale: April 15,1986 A.M./F.M.

A. M.

U.S.A. Inst. No.

33 vs U.S.A.

inst. No. 83

(Country)

(Country)

For instrument No. 33 use $G$ _tables dated March 14,1986

Apply the following corrections to the tables:

To GA or MA values add

To GC or NC values add

To 60 or No values add
$N A$

$N A$

$N A$

For Instrument No. 33 use $N$ tables dated August 26, $1976 \mathrm{FI}$

Apply the following corrections to the tables:

To GA or $M A$ values add
To $G C$ or $M C$ values add
To $G 0$ or ND values add

Notes: "Initial" calibration.

Performed after new "airspace" optical wedge installed into the instrument, optics adjustments mede, and Q-setting table redetermined.

Not: Result of As diservetions good; poor for $c$ - wavelength observations

$I I-42$ 


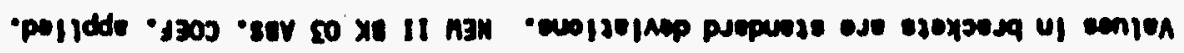

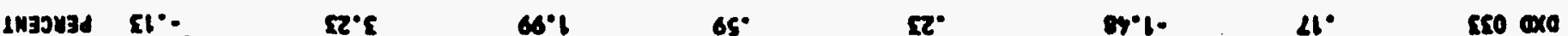

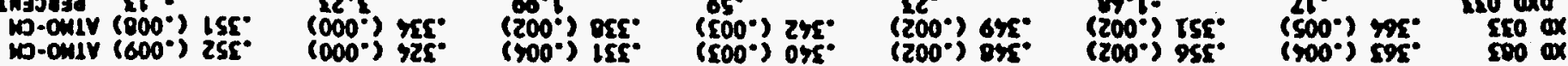

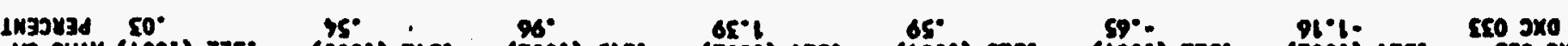

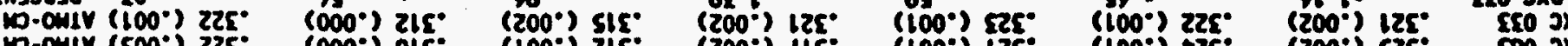

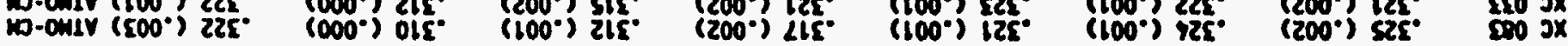

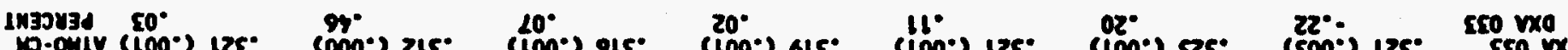

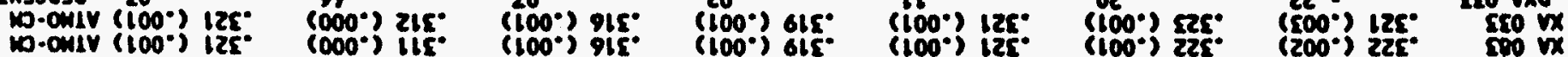

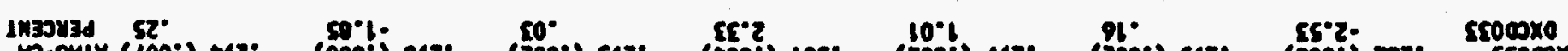

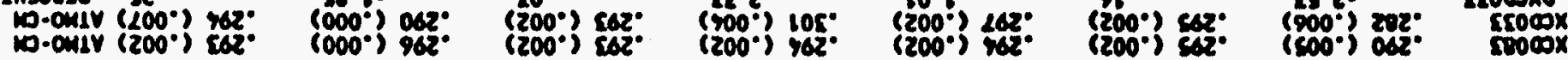

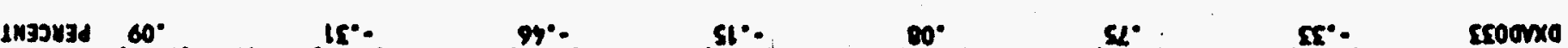

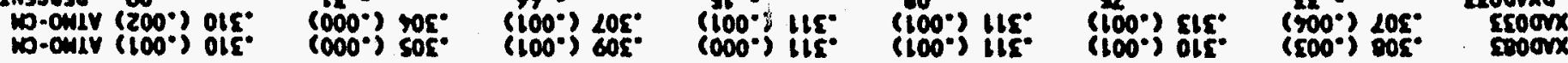

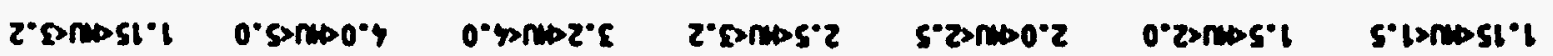

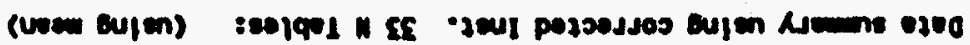

\begin{tabular}{|c|c|c|c|c|c|c|}
\hline $\operatorname{sS2} 2^{\circ}$ & $20^{\circ}$ & $80^{\circ}$ & $\mathrm{SO}^{\circ}$ & $20^{\circ}$ & $90^{\circ}$ & $\cos \infty 0_{1}$ \\
\hline $212^{\circ}$ & $60^{\circ} 2$ & $\boldsymbol{H}^{\circ} \boldsymbol{\varepsilon}-$ & $1 x^{\circ} s-$ & $10^{\circ} 2$ & $0 s^{\circ} z$ & cov 2901 \\
\hline SOE. & $\boldsymbol{H} \cdot \mathbf{L}$ & $\begin{array}{l}x^{*} L- \\
\cos ^{-2}\end{array}$ & $\begin{array}{l}x 6^{\circ} 2- \\
67^{\circ} 2\end{array}$ & 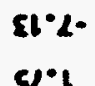 & $\mathrm{SO}^{\circ} \mathrm{L}=$ & oos wol \\
\hline
\end{tabular}

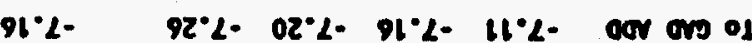

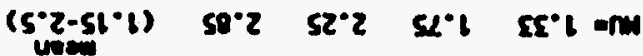

LN3703d $22^{\circ} \cdot$

in $\left(800^{\circ}\right)$ is:

wo-Onlv $\left(600^{\circ}\right)$ zs5.

$\left(61^{\circ} \mathrm{2}\right.$

(200\%)

$\left(50^{\circ}\right)$
$\left(200^{\circ}\right)$ 9r5:
$\left(900^{\circ}\right)$ I5E.

IN3วy3d $96^{\circ} \mathrm{s}$ mont $\left(500^{\circ}\right)$ ire

no-

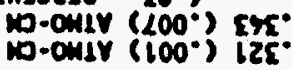

IN30u3d $90^{\circ} 21$

WO-ONLY $\left(900^{\circ}\right)$ oze no-0uly $\left(200^{\circ}\right)$ $162^{\circ}$

$\left(22^{\circ}\right)$

$\left(000^{\circ}\right)$ OLE.

$\left(500^{\circ}\right), 525^{\circ}$

$\left(500^{\circ}\right)$
$\left(100^{\circ}\right) \mathrm{SL}^{\circ}$
$215^{\circ}$

$\left(000^{\circ}\right) 225^{\circ}$

$\left(200^{\circ}\right) \angle 25^{\circ}$

$\left(200^{\circ}\right) 225$.
$\left(100^{\circ}\right) 915^{\circ}$

$15^{\circ} \mathrm{E} \quad 50^{\circ} \mathrm{O}$

$\left(000^{\circ}\right) 905^{\circ}$

$\left(000^{\circ}\right) 962^{\circ}$

$\left(500^{\circ}\right)$ H15

$\left(200^{\circ}\right) 562^{\circ}$

LA37y3d $96^{\circ} \circ$

(0.0)

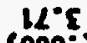

$\left(000^{\circ}\right)$ 9t5

5.0mast.1 0.25nso.4

Ot'?

$\left(200^{\circ}\right) 125$

o'sonstc 

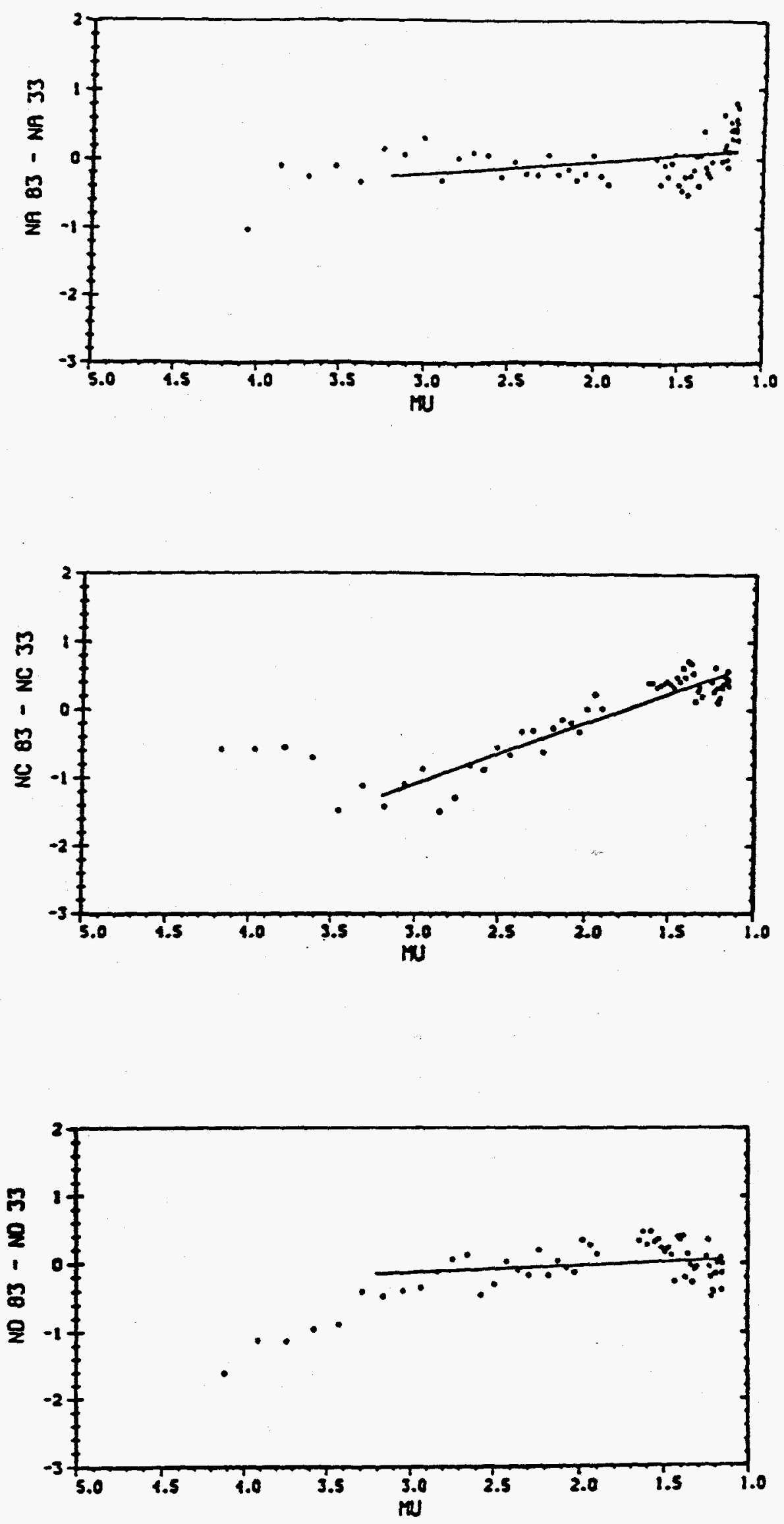

II - 44 
FROM:

G-TABLB

MAR 14, 1986

N - TABLB

INST. 33

APR 15, 1986

VBRSION: $R I$

NA TABLB

\begin{tabular}{|c|c|c|c|c|c|c|c|c|c|c|}
\hline $\mathbf{R}$ & 0 & 1 & 2 & 3 & 4 & 5 & 6 & 7 & 8 & . \\
\hline $\begin{array}{l}0 \\
10 \\
20 \\
30 \\
40\end{array}$ & $\begin{array}{r}-12.1 \\
-2.2 \\
7.7 \\
17.3 \\
26.3\end{array}$ & $\begin{array}{r}-11.1 \\
-1.2 \\
8.6 \\
18.2 \\
27.2\end{array}$ & $\begin{array}{r}-10.1 \\
-.2 \\
9.6 \\
19.1 \\
28.1\end{array}$ & $\begin{array}{r}-9.1 \\
.8 \\
10.6 \\
20.0 \\
29.0\end{array}$ & $\begin{array}{r}-8.1 \\
1.8 \\
11.6 \\
20.9 \\
29.9\end{array}$ & $\begin{array}{r}-7.1 \\
2.8 \\
12.5 \\
21.8 \\
30.8\end{array}$ & $\begin{array}{r}-6.1 \\
3.7 \\
13.5 \\
22.8 \\
31.7\end{array}$ & $\begin{array}{r}-5.2 \\
4.7 \\
14.4 \\
23.7 \\
32.6\end{array}$ & $\begin{array}{r}-4.2 \\
5.7 \\
15.4 \\
24.6 \\
33.5\end{array}$ & $\begin{array}{r}-3.2 \\
6.7 \\
16.3 \\
25.4 \\
34.4\end{array}$ \\
\hline $\begin{array}{l}50 \\
60 \\
70 \\
80 \\
90\end{array}$ & $\begin{array}{l}35.3 \\
44.2 \\
52.9 \\
61.4 \\
70.0\end{array}$ & $\begin{array}{l}36.2 \\
45.1 \\
53.8 \\
62.3 \\
70.9\end{array}$ & $\begin{array}{l}37.1 \\
46.0 \\
54.6 \\
63.1 \\
71.7\end{array}$ & $\begin{array}{l}38.0 \\
46.8 \\
55.5 \\
64.0 \\
72.6\end{array}$ & $\begin{array}{l}38.9 \\
47.7 \\
56.3 \\
64.8 \\
73.4\end{array}$ & $\begin{array}{l}39.8 \\
48.6 \\
57.2 \\
65.7 \\
74.3\end{array}$ & $\begin{array}{l}40.7 \\
49.4 \\
58.0 \\
66.6 \\
75.2\end{array}$ & $\begin{array}{l}41.5 \\
50.3 \\
58.9 \\
67.4 \\
76.0\end{array}$ & $\begin{array}{l}42.4 \\
51.2 \\
59.7 \\
68.3 \\
76.9\end{array}$ & $\begin{array}{l}43.3 \\
52.0 \\
60.6 \\
69.1 \\
77.7\end{array}$ \\
\hline $\begin{array}{l}100 \\
110 \\
120 \\
130 \\
140\end{array}$ & $\begin{array}{r}78.6 \\
87.2 \\
96.0 \\
104.8 \\
113.8\end{array}$ & $\begin{array}{r}79.5 \\
88.1 \\
96.8 \\
105.7 \\
114.7\end{array}$ & $\begin{array}{r}80.3 \\
89.0 \\
97.7 \\
106.6 \\
115.6\end{array}$ & $\begin{array}{r}81.2 \\
89.8 \\
98.6 \\
107.5 \\
116.5\end{array}$ & $\begin{array}{r}82.0 \\
90.7 \\
99.5 \\
108.4 \\
117.5\end{array}$ & $\begin{array}{r}82.9 \\
91.6 \\
100.4 \\
109.3 \\
118.4\end{array}$ & $\begin{array}{r}83.8 \\
92.5 \\
101.3 \\
110.2 \\
119.3\end{array}$ & $\begin{array}{r}84.6 \\
93.3 \\
102.1 \\
111.1 \\
120.2\end{array}$ & $\begin{array}{r}85.5 \\
94.2 \\
103.0 \\
112.0 \\
121.1\end{array}$ & $\begin{array}{r}86.4 \\
95.1 \\
103.9 \\
112.9 \\
122.0\end{array}$ \\
\hline $\begin{array}{l}150 \\
160 \\
170 \\
180 \\
190\end{array}$ & $\begin{array}{l}122.9 \\
132.1 \\
141.4 \\
150.9 \\
160.4\end{array}$ & $\begin{array}{l}123.8 \\
133.1 \\
142.4 \\
151.8 \\
161.4\end{array}$ & $\begin{array}{l}124.8 \\
134.0 \\
143.3 \\
152.8 \\
162.4\end{array}$ & $\begin{array}{l}125.7 \\
134.9 \\
144.3 \\
153.7 \\
163.3\end{array}$ & $\begin{array}{l}126.6 \\
135.8 \\
145.2 \\
154.7 \\
164.3\end{array}$ & $\begin{array}{l}127.5 \\
136.8 \\
146.1 \\
155.6 \\
165.3\end{array}$ & $\begin{array}{l}128.4 \\
137.7 \\
147.1 \\
156.6 \\
166.3\end{array}$ & $\begin{array}{l}129.4 \\
138.6 \\
148.0 \\
157.5 \\
167.3\end{array}$ & $\begin{array}{l}130.3 \\
139.6 \\
149.0 \\
158.5 \\
168.2\end{array}$ & $\begin{array}{l}131.2 \\
140.5 \\
149.9 \\
159.5 \\
169.2\end{array}$ \\
\hline $\begin{array}{l}200 \\
210 \\
220 \\
230 \\
240\end{array}$ & $\begin{array}{l}170.2 \\
180.2 \\
190.3 \\
200 \cdot 3 \\
210.3\end{array}$ & $\begin{array}{l}171.2 \\
181 \cdot 2 \\
191 \cdot 3 \\
201 \cdot 3 \\
211.3\end{array}$ & $\begin{array}{l}172.2 \\
182.2 \\
192.3 \\
202.3 \\
212.3\end{array}$ & $\begin{array}{l}173.2 \\
183.2 \\
193.3 \\
203.3 \\
213.3\end{array}$ & $\begin{array}{l}174.2 \\
184.2 \\
194.3 \\
204.3 \\
214.3\end{array}$ & $\begin{array}{l}175.2 \\
185.2 \\
195.3 \\
205.3 \\
215.3\end{array}$ & $\begin{array}{l}176.2 \\
186.3 \\
196.3 \\
206.3 \\
216.3\end{array}$ & $\begin{array}{l}177.2 \\
187.3 \\
197.3 \\
207.3 \\
217.3\end{array}$ & $\begin{array}{l}178.2 \\
188.3 \\
198.3 \\
208.3 \\
218.2\end{array}$ & $\begin{array}{l}179.2 \\
189.3 \\
199.3 \\
209.3 \\
219.2\end{array}$ \\
\hline $\begin{array}{l}250 \\
260 \\
270 \\
280 \\
290\end{array}$ & $\begin{array}{l}220.2 \\
230.0 \\
240.1 \\
250.1 \\
260.0\end{array}$ & $\begin{array}{l}221.2 \\
231.0 \\
241.1 \\
251.0 \\
261.0\end{array}$ & $\begin{array}{l}222.1 \\
232.0 \\
242.1 \\
252.0 \\
262.0\end{array}$ & $\begin{array}{l}223.1 \\
233.0 \\
243.1 \\
253.0 \\
263.0\end{array}$ & $\begin{array}{l}224.1 \\
234.0 \\
244.1 \\
254.0 \\
264.0\end{array}$ & $\begin{array}{l}225.1 \\
235.0 \\
245.1 \\
255.0 \\
265.0\end{array}$ & $\begin{array}{l}226.1 \\
236.0 \\
246.1 \\
256.0 \\
265.9\end{array}$ & $\begin{array}{l}227.0 \\
237.0 \\
247.1 \\
257.0 \\
266.9\end{array}$ & $\begin{array}{l}228.0 \\
238.1 \\
248.1 \\
258.0 \\
267.9\end{array}$ & $\begin{array}{l}229.0 \\
239.1 \\
249.1 \\
259.0 \\
268.9\end{array}$ \\
\hline 300 & & & & & & & & & & \\
\hline
\end{tabular}

TABLB GENERATED ON $92 / 09 / 15$. 
FROM:

N-TABLB

G-TABLB

MAR 14, 1986

INST. 33

APR 15, 1986

VBRSION: RI

NC TABLB

\begin{tabular}{|c|c|c|c|c|c|c|c|c|c|c|}
\hline $\mathbf{R}$ & 0 & 1 & 2 & 3 & 4 & 5 & 6 & 7 & 8 & \\
\hline $\begin{array}{l}0 \\
10 \\
20 \\
30 \\
40\end{array}$ & $\begin{array}{r}-7.9 \\
2.1 \\
12.9 \\
21.5 \\
30.6\end{array}$ & $\begin{array}{r}-6.9 \\
3.1 \\
12.9 \\
22.4 \\
31.5\end{array}$ & $\begin{array}{r}-5.9 \\
4.1 \\
13.9 \\
23.3 \\
32.4\end{array}$ & $\begin{array}{r}-4.9 \\
5.0 \\
24.8 \\
24.2 \\
33.3\end{array}$ & $\begin{array}{r}-3.9 \\
6.0 \\
15.8 \\
25.2 \\
34.2\end{array}$ & $\begin{array}{r}-2.9 \\
7.0 \\
16.7 \\
26.1 \\
35.1\end{array}$ & $\begin{array}{r}-1.9 \\
8.0 \\
17.7 \\
27.0 \\
36.0\end{array}$ & $\begin{array}{r}-.9 \\
9.0 \\
18.6 \\
27.9 \\
36.9\end{array}$ & $\begin{array}{l}.1 \\
10.0 \\
19.6 \\
28.8 \\
37.8\end{array}$ & $\begin{array}{l}1.1 \\
10.9 \\
20.5 \\
29.7 \\
38.7\end{array}$ \\
\hline $\begin{array}{l}50 \\
60 \\
70 \\
80 \\
90\end{array}$ & $\begin{array}{l}39.6 \\
48.4 \\
57.1 \\
65.7 \\
74.2\end{array}$ & $\begin{array}{l}40.4 \\
49.3 \\
58.0 \\
66.5 \\
75.0\end{array}$ & $\begin{array}{l}41.3 \\
50.2 \\
58.8 \\
67.4 \\
75.9\end{array}$ & $\begin{array}{l}42.2 \\
51.0 \\
59.7 \\
68.2 \\
76.7\end{array}$ & $\begin{array}{l}43.1 \\
51.9 \\
60.6 \\
69.1 \\
77.6\end{array}$ & $\begin{array}{l}44.0 \\
52.8 \\
61.4 \\
69.9 \\
78.4\end{array}$ & $\begin{array}{l}44.9 \\
53.7 \\
62.3 \\
70.8 \\
79.3\end{array}$ & $\begin{array}{l}45.8 \\
54.5 \\
63.1 \\
71.6 \\
80.1\end{array}$ & $\begin{array}{l}46.6 \\
55.4 \\
64.0 \\
72.5 \\
81.0\end{array}$ & $\begin{array}{l}47.5 \\
56.3 \\
64.8 \\
73.3 \\
81.8\end{array}$ \\
\hline $\begin{array}{l}100 \\
110 \\
120 \\
130 \\
140\end{array}$ & $\begin{array}{r}82.7 \\
91.3 \\
99.9 \\
108.7 \\
117.5\end{array}$ & $\begin{array}{r}83.5 \\
92.1 \\
100.8 \\
209.5 \\
128.4\end{array}$ & $\begin{array}{r}84.4 \\
93.0 \\
201.7 \\
110.4 \\
119.3\end{array}$ & $\begin{array}{r}85.2 \\
93.8 \\
102.5 \\
111.3 \\
120.2\end{array}$ & $\begin{array}{r}96.1 \\
94.7 \\
103.4 \\
112.2 \\
121.1\end{array}$ & $\begin{array}{r}87.0 \\
95.6 \\
104.3 \\
113.1 \\
122.0\end{array}$ & $\begin{array}{r}87.8 \\
96.4 \\
105.2 \\
114.0 \\
122.9\end{array}$ & $\begin{array}{r}88.7 \\
97.3 \\
106.0 \\
114.8 \\
123.8\end{array}$ & $\begin{array}{r}89.5 \\
98.2 \\
106.9 \\
115.7 \\
124.7\end{array}$ & $\begin{array}{r}90.4 \\
99.1 \\
107.8 \\
116.6 \\
125.6\end{array}$ \\
\hline $\begin{array}{l}50 \\
60 \\
70 \\
80 \\
90\end{array}$ & $\begin{array}{l}126.5 \\
135.6 \\
144.8 \\
154.0 \\
163.5\end{array}$ & $\begin{array}{l}127.4 \\
136.5 \\
145.7 \\
155.0 \\
164.4\end{array}$ & $\begin{array}{l}128.3 \\
137.4 \\
146.6 \\
155.9 \\
165.4\end{array}$ & $\begin{array}{l}129.2 \\
138.3 \\
147.5 \\
156.8 \\
166.3\end{array}$ & $\begin{array}{l}130.1 \\
139.2 \\
148.4 \\
157.8 \\
167.3\end{array}$ & $\begin{array}{l}131.0 \\
140.2 \\
149.4 \\
158.7 \\
168.2\end{array}$ & $\begin{array}{l}132.0 \\
141.1 \\
150.3 \\
159.7 \\
169.2\end{array}$ & $\begin{array}{l}132.9 \\
142.0 \\
151.2 \\
160.6 \\
170.2\end{array}$ & $\begin{array}{l}133.8 \\
142.9 \\
152.2 \\
161.6 \\
171.1\end{array}$ & $\begin{array}{l}134.7 \\
143.8 \\
153.1 \\
162.5 \\
172.1\end{array}$ \\
\hline $\begin{array}{l}200 \\
210 \\
220 \\
230 \\
240\end{array}$ & $\begin{array}{l}173.1 \\
182.9 \\
192.8 \\
202.7 \\
212.5\end{array}$ & $\begin{array}{l}174.0 \\
183.9 \\
193.8 \\
203.7 \\
213.5\end{array}$ & $\begin{array}{l}175.0 \\
184.8 \\
194.8 \\
204.6 \\
214.5\end{array}$ & $\begin{array}{l}176.0 \\
185.8 \\
195.8 \\
205.6 \\
215.5\end{array}$ & $\begin{array}{l}177.0 \\
186.8 \\
196.7 \\
206.6 \\
216.4\end{array}$ & $\begin{array}{l}177.9 \\
187.8 \\
197.7 \\
207.6 \\
217.4\end{array}$ & $\begin{array}{l}178.9 \\
188.8 \\
198.7 \\
208.6 \\
218.4\end{array}$ & $\begin{array}{l}179.9 \\
189.8 \\
199.7 \\
209.6 \\
219.4\end{array}$ & $\begin{array}{l}180.9 \\
190.8 \\
200.7 \\
210.6 \\
220.3\end{array}$ & $\begin{array}{l}181.9 \\
191.8 \\
201.7 \\
211.5 \\
221.3\end{array}$ \\
\hline $\begin{array}{l}250 \\
260 \\
270 \\
280\end{array}$ & $\begin{array}{l}222.3 \\
232.1 \\
241.9 \\
251.8 \\
261.6\end{array}$ & $\begin{array}{l}223.3 \\
233.0 \\
242.9 \\
252.8 \\
262.6\end{array}$ & $\begin{array}{l}224.2 \\
234.0 \\
243.9 \\
253.8 \\
263.5\end{array}$ & $\begin{array}{l}225.2 \\
235.0 \\
244.9 \\
254.8 \\
264.5\end{array}$ & $\begin{array}{l}226.2 \\
236.0 \\
245.9 \\
255.8 \\
265.5\end{array}$ & $\begin{array}{l}227.2 \\
237.0 \\
246.9 \\
256.7 \\
266.5\end{array}$ & $\begin{array}{l}228.2 \\
238.0 \\
247.9 \\
257.7 \\
267.5\end{array}$ & $\begin{array}{l}229.1 \\
239.0 \\
248.9 \\
258.7\end{array}$ & $\begin{array}{l}230.1 \\
240.0 \\
249.9 \\
259.7\end{array}$ & $\begin{array}{l}231.1 \\
241.0 \\
250.8 \\
260.6\end{array}$ \\
\hline
\end{tabular}

TABLB GBNBRATBD ON 92/09/15. 
PROM:

N-TABLB

G-TABLB

MAR 14, 1986

INST. 33

APR 15, 1986

VBRSION: RI

ND TABLB

\begin{tabular}{|c|c|c|c|c|c|c|c|c|c|c|}
\hline $\boldsymbol{R}$ & 0 & 1 & 2 & 3 & 4 & 5 & 6 & 7 & 8 & 9 \\
\hline $\begin{array}{l}0 \\
10 \\
20 \\
30 \\
40\end{array}$ & $\begin{array}{r}-4.9 \\
5.0 \\
14.9 \\
24.4 \\
33.5\end{array}$ & $\begin{array}{r}-3.9 \\
6.0 \\
15.8 \\
25.3 \\
34.4\end{array}$ & $\begin{array}{r}-3.0 \\
7.0 \\
16.8 \\
26.3 \\
35.3\end{array}$ & $\begin{array}{r}-2.0 \\
7.9 \\
17.8 \\
27.2 \\
36.2\end{array}$ & $\begin{array}{r}-1.0 \\
8.9 \\
18.7 \\
28.1 \\
37.1\end{array}$ & $\begin{array}{r}.0 \\
9.9 \\
19.7 \\
29.0 \\
38.0\end{array}$ & $\begin{array}{r}1.0 \\
10.9 \\
20.6 \\
29.9 \\
38.9\end{array}$ & $\begin{array}{r}2.0 \\
11.9 \\
21.6 \\
30.8 \\
39.8\end{array}$ & $\begin{array}{r}3.0 \\
12.9 \\
22.5 \\
31.7 \\
40.7\end{array}$ & $\begin{array}{r}4.0 \\
13.9 \\
23.5 \\
32.6 \\
41.6\end{array}$ \\
\hline $\begin{array}{l}50 \\
60 \\
70 \\
80 \\
90\end{array}$ & $\begin{array}{l}42.5 \\
51.3 \\
60.0 \\
68.5 \\
77.0\end{array}$ & $\begin{array}{l}43.4 \\
52.2 \\
60.9 \\
69.4 \\
77.9\end{array}$ & $\begin{array}{l}44.3 \\
53.1 \\
61.7 \\
70.2 \\
78.7\end{array}$ & $\begin{array}{l}45.2 \\
54.0 \\
62.6 \\
71.1 \\
79.6\end{array}$ & $\begin{array}{l}46.0 \\
54.9 \\
63.4 \\
71.9 \\
80.4\end{array}$ & $\begin{array}{l}46.9 \\
55.7 \\
64.3 \\
72.8 \\
81.2\end{array}$ & $\begin{array}{l}47.8 \\
56.6 \\
65.1 \\
73.6 \\
82.1\end{array}$ & $\begin{array}{l}48.7 \\
57.4 \\
66.0 \\
74.5 \\
82.9\end{array}$ & $\begin{array}{r}49.6 \\
58.3 \\
66.8 \\
75.3 \\
83.8\end{array}$ & $\begin{array}{l}50.5 \\
59.2 \\
67.7 \\
76.2 \\
84.6\end{array}$ \\
\hline $\begin{array}{l}100 \\
110 \\
120 \\
130 \\
140\end{array}$ & $\begin{array}{r}85.5 \\
94.0 \\
102.6 \\
111.3 \\
120.1\end{array}$ & $\begin{array}{r}86.3 \\
94.8 \\
103.5 \\
112.2 \\
121.0\end{array}$ & $\begin{array}{r}87.2 \\
95.7 \\
104.3 \\
113.0 \\
121.8\end{array}$ & $\begin{array}{r}88.0 \\
96.6 \\
105.2 \\
113.9 \\
122.7\end{array}$ & $\begin{array}{r}88.9 \\
97.4 \\
106.1 \\
114.8 \\
123.6\end{array}$ & $\begin{array}{r}89.7 \\
98.3 \\
106.9 \\
115.7 \\
124.5\end{array}$ & $\begin{array}{r}90.6 \\
99.1 \\
107.8 \\
116.5 \\
125.4\end{array}$ & $\begin{array}{r}91.4 \\
100.0 \\
108.7 \\
117.4 \\
126.3\end{array}$ & $\begin{array}{r}92.3 \\
100.9 \\
109.5 \\
118.3 \\
127.2\end{array}$ & $\begin{array}{r}93.1 \\
101.7 \\
110.4 \\
119.2 \\
128.1\end{array}$ \\
\hline $\begin{array}{l}150 \\
160 \\
170 \\
180 \\
190\end{array}$ & $\begin{array}{l}129.0 \\
138.0 \\
147.1 \\
156.2 \\
165.6\end{array}$ & $\begin{array}{l}129.9 \\
138.9 \\
148.0 \\
157.2 \\
166.5\end{array}$ & $\begin{array}{l}130.8 \\
139.8 \\
148.9 \\
158.1 \\
167.4\end{array}$ & $\begin{array}{l}131.7 \\
140.7 \\
149.8 \\
159.0 \\
168.4\end{array}$ & $\begin{array}{l}132.6 \\
141.6 \\
150.7 \\
160.0 \\
169.3\end{array}$ & $\begin{array}{l}133.5 \\
142.5 \\
151.6 \\
160.9 \\
170.3\end{array}$ & $\begin{array}{l}134.4 \\
143.4 \\
152.6 \\
161.8 \\
171.2\end{array}$ & $\begin{array}{l}135.3 \\
144.3 \\
153.5 \\
162.7 \\
172.2\end{array}$ & $\begin{array}{l}136.2 \\
145.2 \\
154.4 . \\
163.7 \\
173.1\end{array}$ & $\begin{array}{l}137.1 \\
146.1 \\
155.3 \\
164.6 \\
174.1\end{array}$ \\
\hline $\begin{array}{l}200 \\
210 \\
220 \\
230 \\
240\end{array}$ & $\begin{array}{l}175.0 \\
184.8 \\
194.6 \\
204.4 \\
214.2\end{array}$ & $\begin{array}{l}176.0 \\
185.7 \\
195.5 \\
205.4 \\
215.1\end{array}$ & $\begin{array}{l}177.0 \\
186.7 \\
196.5 \\
206.3 \\
216.1\end{array}$ & $\begin{array}{l}177.9 \\
187.7 \\
197.5 \\
207.3 \\
217.1\end{array}$ & $\begin{array}{l}178.9 \\
188.7 \\
198.5 \\
208.3 \\
218.1\end{array}$ & $\begin{array}{l}179.9 \\
189.7 \\
199.5 \\
209.3 \\
219.0\end{array}$ & $\begin{array}{l}180.8 \\
190.6 \\
200.4 \\
210.3 \\
220.0\end{array}$ & $\begin{array}{l}181.8 \\
191.6 \\
201.4 \\
211.2 \\
220.9\end{array}$ & $\begin{array}{l}182.8 \\
192.6 \\
202.4 \\
212.2 \\
221.9\end{array}$ & $\begin{array}{l}183.8 \\
193.6 \\
203.4 \\
213.2 \\
222.9\end{array}$ \\
\hline $\begin{array}{l}250 \\
260 \\
270 \\
280 \\
290\end{array}$ & $\begin{array}{l}223.8 \\
233.5 \\
243.4 \\
253.1 \\
262.9\end{array}$ & $\begin{array}{l}224.8 \\
234.5 \\
244.4 \\
254.1 \\
263.9\end{array}$ & $\begin{array}{l}225.8 \\
235.5 \\
245.3 \\
255.1 \\
264.8\end{array}$ & $\begin{array}{l}226.7 \\
236.5 \\
246.3 \\
256.1 \\
265.8\end{array}$ & $\begin{array}{l}227.7 \\
237.5 \\
247.3 \\
257.0 \\
266.8\end{array}$ & $\begin{array}{l}228.6 \\
238.4 \\
248.3 \\
258.0 \\
267.8\end{array}$ & $\begin{array}{l}229.6 \\
239.4 \\
249.3 \\
259.0 \\
268.7\end{array}$ & $\begin{array}{l}230.6 \\
240.4 \\
250.2 \\
259.9 \\
269.7\end{array}$ & $\begin{array}{l}231.6 \\
241.4 \\
251.2 \\
260.9 \\
270.7\end{array}$ & $\begin{array}{l}232.6 \\
242.4 \\
252.2 \\
261.9\end{array}$ \\
\hline
\end{tabular}

TABLE GENERATED ON 92/09/15. 
INST. NO: 33

DATE, April 15, $1986 \mathrm{RI}$

REFERENCE STAHDARD LAMP DATA

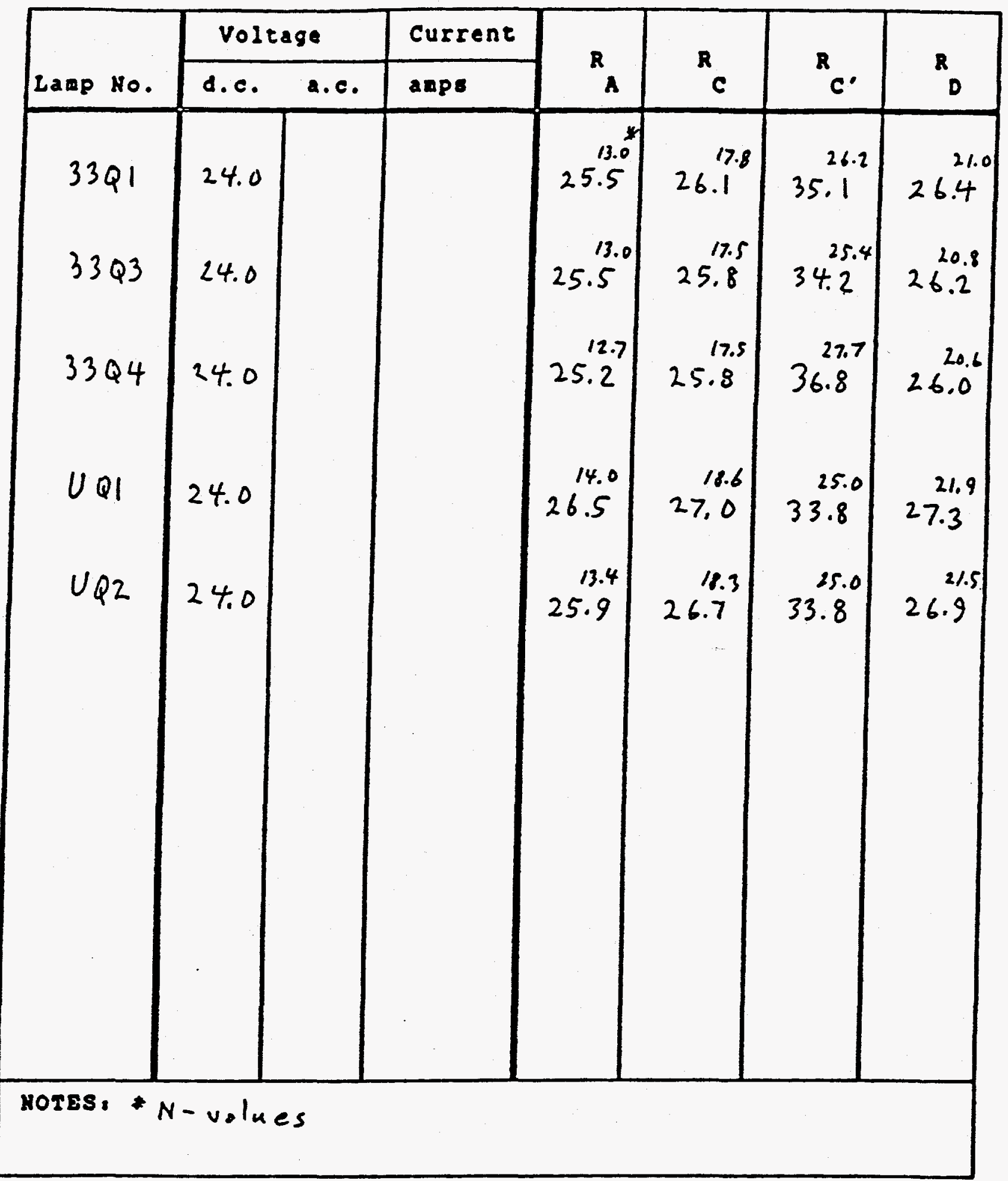




\section{DOBSON OZONE SPECTROPHOTOMETER CALIBRATION}

$$
\text { Place: Bonlder, Colorado }
$$

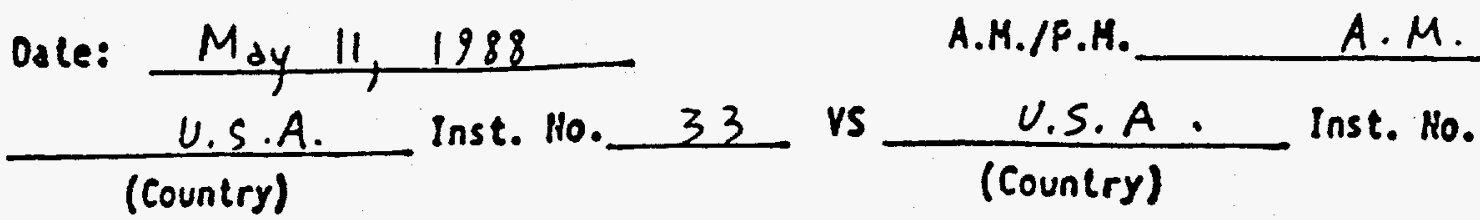
For instrument No. 33 use $-N$ tables dated A pril 15, 1986RI Apply the following corrections to the tables:

To Gh or MA values add $-2.0$

To GC or MC values add $-2.1$

To $G 0$ or NO values add

$\frac{-2.0}{-2.1}$

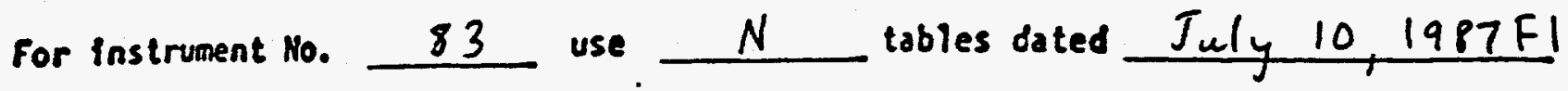
Apply the following corrections to the tables:

To GA or MA values add

$\frac{-0.4}{-0.3}$

To GC or MC values add

To 60 or ND values add

$$
-0.1
$$

MOTES: "Find" calibretion, with instrument as received from Bismarck 
Date eumary ueing Inat. 33 a tebles dated

April 15, 1966:

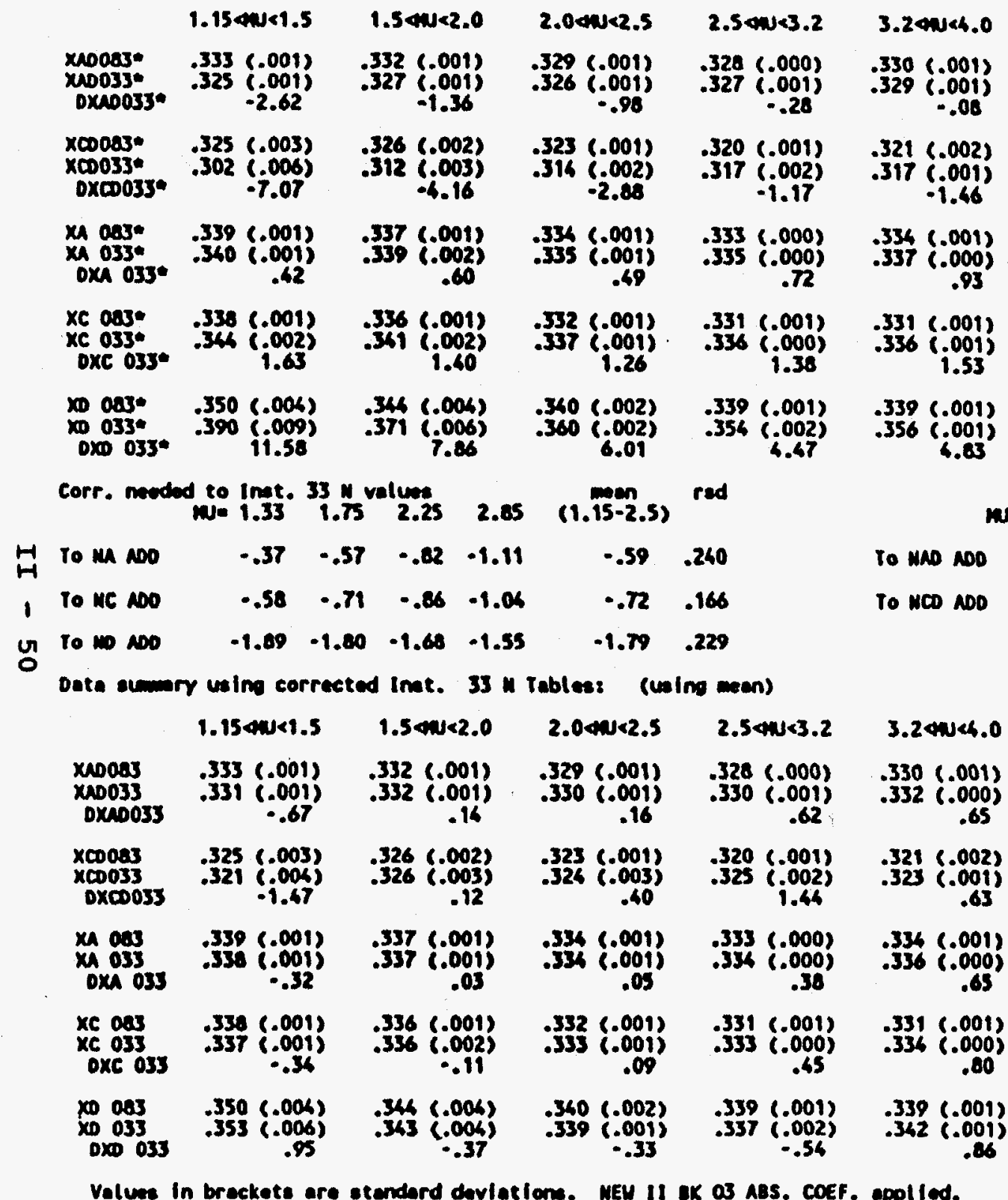

velue in breckete are stendard devilations. MEW II aK 03 ABS, COEF. appll Iod.
Callb Inat. as ve 33 May 11, 1900 A

$4.0000 \times 5.0 \quad 1.154003 .2$

$.331(.002)$ ATmo-ch

-i.3i PERCENT

$.324(.002)$ Armo-ch

$.311(.005)$ ATHO-CH

-3.83 PERCENT

$.336(.002)$ ATmo-ch .56 PERCEMT

$.334(.003)$ atmo-ch .339 (.003) ATMO-CA

$.363(.006)$ ATmo-C $.360(.016)$ ATMO-CH

$m=1.33 \quad 1.75 \quad 2.25 \quad 2.85 \quad(1.15-2.5)$

$\begin{array}{lllll}1.53 & 1.22 & .87 & .44 & 1.21\end{array}$

$\begin{array}{lllll}1.31 & 1.09 & .03 & .51 & 1.08\end{array}$

$4.0 \times 40 \times 5.0 \quad 1.15 \times 4 \times 3.2$

.331 (.002) ATmo-Ca .331 (.001) ATMO-CA .06 PERCENT

$.326(.002)$ ATmO-CM $.326(.002)$ ATHO-CN .12 PERCENT

.336 (.002) ATmO-CH $.336 \cdot(.002)$ atmo-cn

$.334(.003)$ Armo-ch .335 (.002) ATMO-cn $.363(.006)$ ATmo-ch $.363(.006)$ AIMO.CH 


\section{APPENDIX 2.D}

DOBSON INSTRUMENT 79 SAMPLE CALIBRATION DATA AUGUST 25, 1981 AND JUNE 19, 1985

(a) Stable optical wedge

(b) Observations exhibit a $\mu$-dependency relative to Dobson instrument 83 . 


\section{DOBSON OZONE SPECTROPHOTOMETER CALIBRATION}

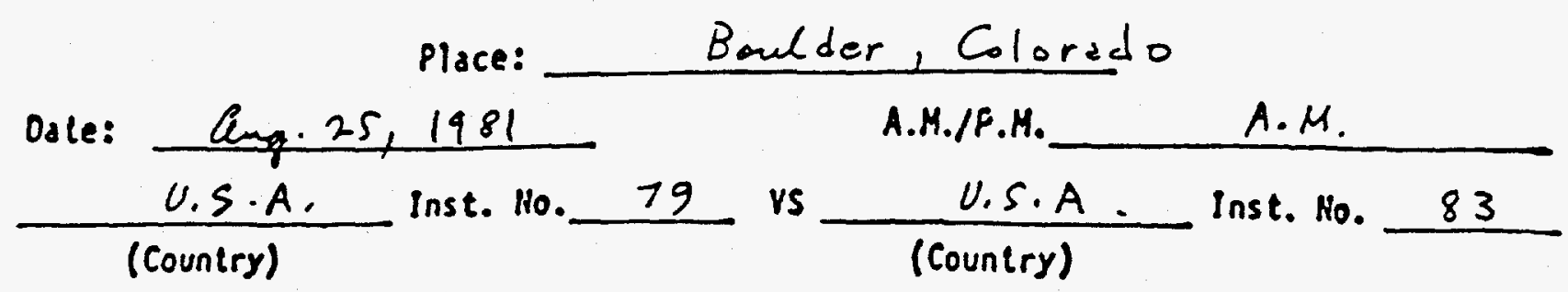

For instrument No. 79 use $\quad G$ tables dated Aug. 24, 1981 Apply the following corrections to the tables:

To Gh or MA values add

To GC or NC values add

$\frac{N A}{N A} \frac{N A}{N}$

To 60 or ND values aod

For instrument No. 83 use $-N$ tables dated ang. 26,1976 FI Appiy the following corrections to the tables:

To GA or MA values add

To GC or NC values add

To 60 or ND values add

$\frac{+3.4}{+3.8}$

NOTES: "Initial" instrument calibrdion, performed after eleaning optics and installing a new cobjlt filter into the instrumant. 


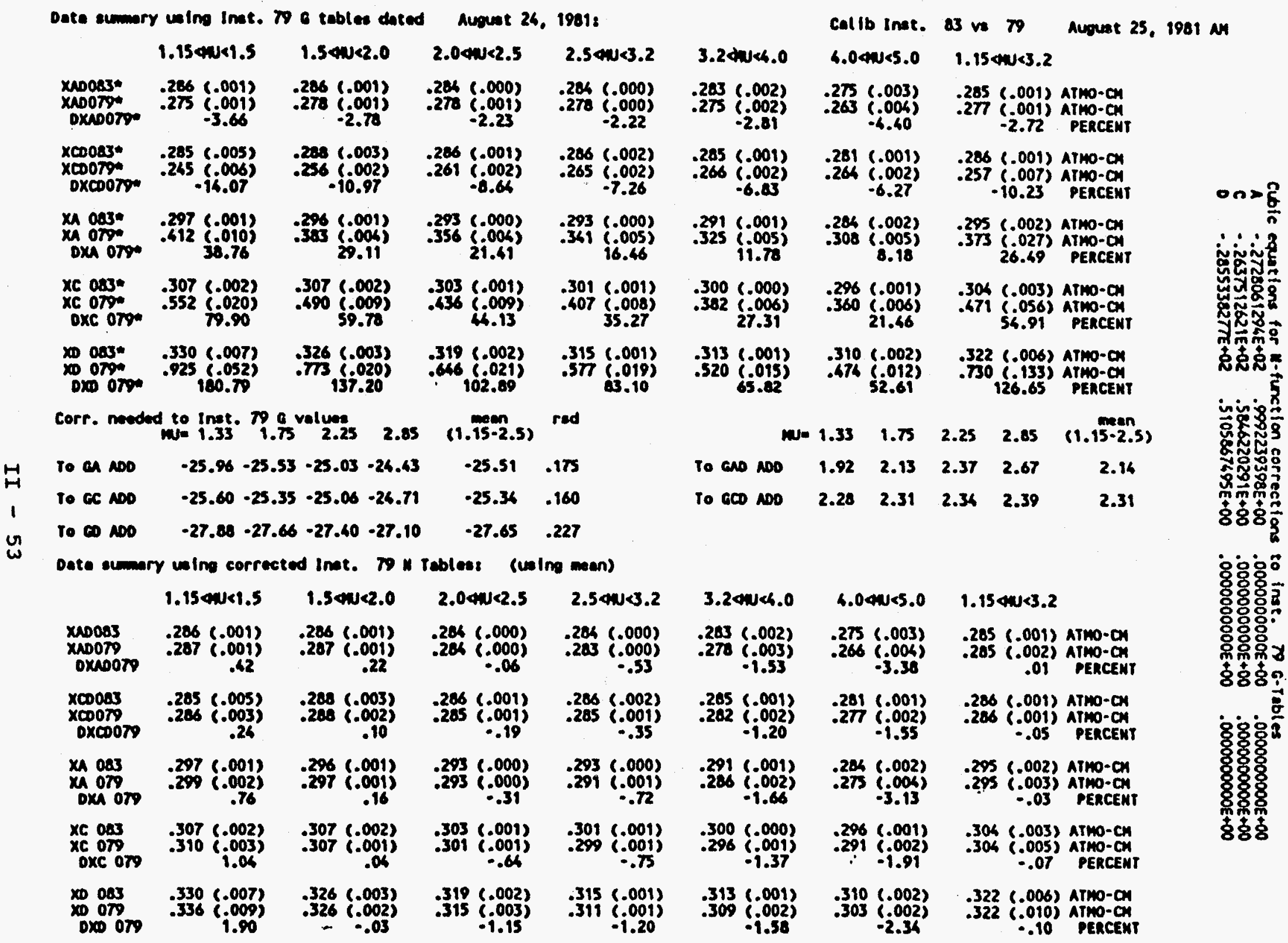



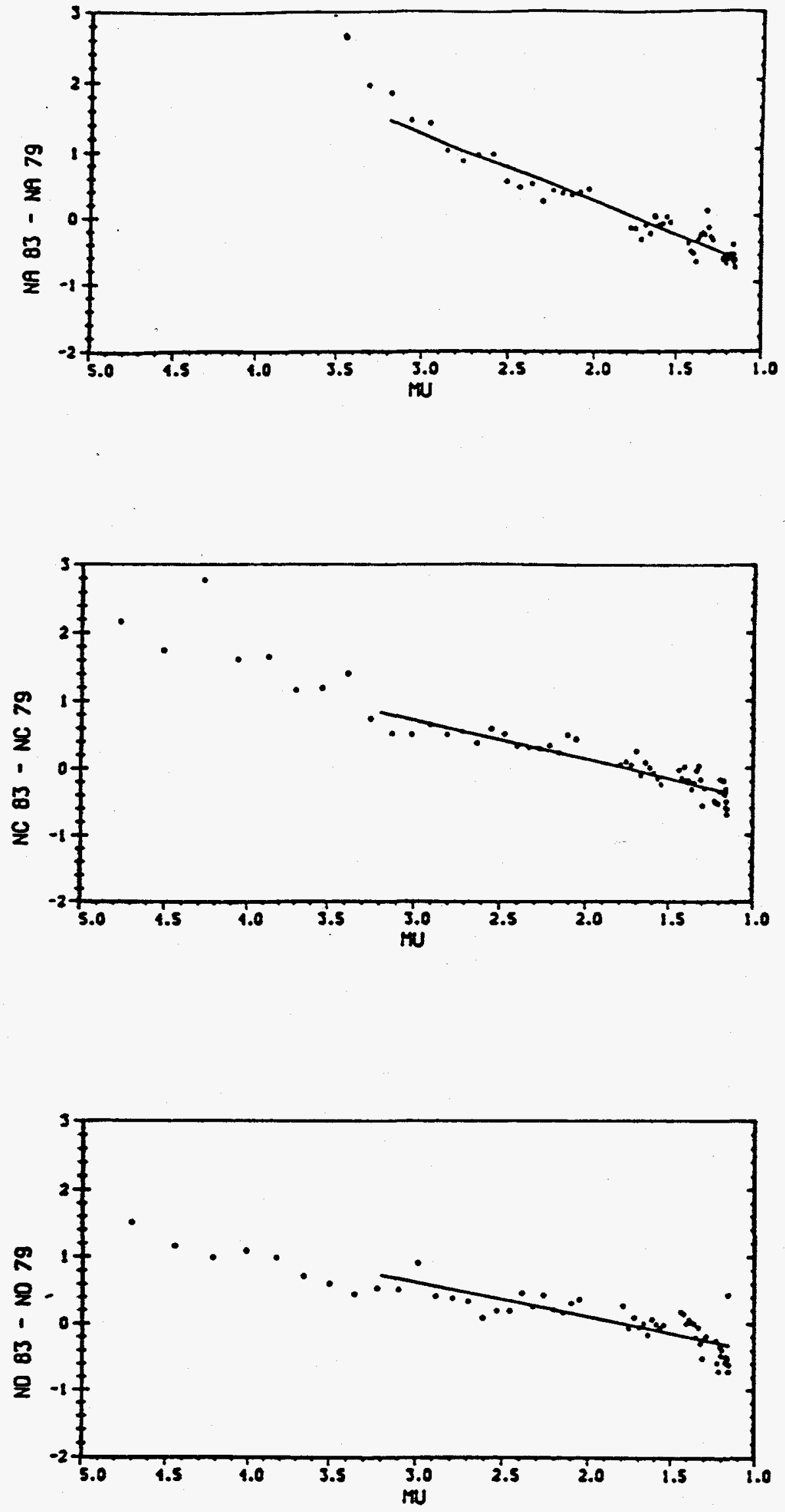

$I I-54$ 
FROM:

N-TABLE

G-TABLB

AUG 24, 1981

INST. 79

AUG 25, 1981

VBRSION: $R 1$

NA TABLB

\begin{tabular}{|c|c|c|c|c|c|c|c|c|c|c|}
\hline $\mathbf{R}$ & 0 & 1 & 2 & 3 & 4 & 5 & 6 & 7 & 8 & 9 \\
\hline $\begin{array}{l}0 \\
10 \\
20 \\
30 \\
40\end{array}$ & $\begin{array}{r}-31.4 \\
-19.6 \\
-8.0 \\
3.8 \\
14.6\end{array}$ & $\begin{array}{r}-30.2 \\
-18.4 \\
-6.8 \\
4.9 \\
15.6\end{array}$ & $\begin{array}{r}-29.1 \\
-17.3 \\
-5.6 \\
6.0 \\
16.6\end{array}$ & $\begin{array}{r}-27.9 \\
-16.2 \\
-4.4 \\
7.2 \\
17.6\end{array}$ & $\begin{array}{r}-26.7 \\
-15.0 \\
-3.2 \\
8.3 \\
18.5\end{array}$ & $\begin{array}{r}-25.5 \\
-13.9 \\
-2.1 \\
9.4 \\
19.5\end{array}$ & $\begin{array}{r}-24.3 \\
-12.7 \\
-.9 \\
10.5 \\
20.4\end{array}$ & $\begin{array}{r}-23.1 \\
-11.6 \\
.3 \\
11.6 \\
21.4\end{array}$ & $\begin{array}{r}-22.0 \\
-10.4 \\
1.4 \\
12.6 \\
22.4\end{array}$ & $\begin{array}{r}-20.8 \\
-9.2 \\
2.6 \\
13.6 \\
23.3\end{array}$ \\
\hline $\begin{array}{l}50 \\
60 \\
70 \\
80 \\
90\end{array}$ & $\begin{array}{l}24.3 \\
33.5 \\
42.6 \\
51.7 \\
61.2\end{array}$ & $\begin{array}{l}25.2 \\
34.5 \\
43.5 \\
52.6 \\
62.2\end{array}$ & $\begin{array}{l}26.1 \\
35.4 \\
44.5 \\
53.6 \\
63.1\end{array}$ & $\begin{array}{l}27.1 \\
36.3 \\
45.4 \\
54.5 \\
64.1\end{array}$ & $\begin{array}{l}28.0 \\
37.2 \\
46.3 \\
55.5 \\
65.1\end{array}$ & $\begin{array}{l}29.0 \\
38.1 \\
47.2 \\
56.4 \\
66.1\end{array}$ & $\begin{array}{l}29.9 \\
39.0 \\
48.1 \\
57.3 \\
67.1\end{array}$ & $\begin{array}{l}30.8 \\
39.9 \\
49.0 \\
58.3 \\
68.0\end{array}$ & $\begin{array}{l}31.7 \\
40.8 \\
49.9 \\
59.2 \\
69.0\end{array}$ & $\begin{array}{l}32.6 \\
41.7 \\
50.8 \\
60.2 \\
70.0\end{array}$ \\
\hline $\begin{array}{l}100 \\
110 \\
120 \\
130 \\
140\end{array}$ & $\begin{array}{r}71.0 \\
81.2 \\
91.3 \\
101.4 \\
111.7\end{array}$ & $\begin{array}{r}72.0 \\
82.2 \\
92.3 \\
102.5 \\
112.7\end{array}$ & $\begin{array}{r}73.0 \\
83.2 \\
93.3 \\
103.5 \\
113.7\end{array}$ & $\begin{array}{r}74.1 \\
84.2 \\
94.3 \\
104.5 \\
114.7\end{array}$ & $\begin{array}{r}75.1 \\
85.2 \\
95.3 \\
105.5 \\
115.7\end{array}$ & $\begin{array}{r}76.1 \\
86.2 \\
96.3 \\
106.6 \\
116.8\end{array}$ & $\begin{array}{r}77.1 \\
87.2 \\
97.4 \\
107.6 \\
117.8\end{array}$ & $\begin{array}{r}78.1 \\
88.2 \\
98.4 \\
108.6 \\
118.8\end{array}$ & $\begin{array}{r}79.1 \\
89.2 \\
99.4 \\
109.6 \\
119.8\end{array}$ & $\begin{array}{r}80.1 \\
90.2 \\
100.4 \\
110.7 \\
120.8\end{array}$ \\
\hline $\begin{array}{l}150 \\
160 \\
170 \\
180 \\
190\end{array}$ & $\begin{array}{l}121.8 \\
131.8 \\
142.0 \\
152.0 \\
162.0\end{array}$ & $\begin{array}{l}122.8 \\
132.8 \\
143.0 \\
153.0 \\
163.1\end{array}$ & $\begin{array}{l}123.8 \\
133.9 \\
144.0 \\
154.0 \\
164.1\end{array}$ & $\begin{array}{l}124.8 \\
134.9 \\
145.0 \\
155.0 \\
165.1\end{array}$ & $\begin{array}{l}125.8 \\
135.9 \\
146.0 \\
156.0 \\
166.1\end{array}$ & $\begin{array}{l}126.8 \\
136.9 \\
147.0 \\
157.0 \\
167.1\end{array}$ & $\begin{array}{l}127.8 \\
137.9 \\
148.0 \\
158.0 \\
168.1\end{array}$ & $\begin{array}{l}128.8 \\
138.9 \\
149.0 \\
159.0 \\
169.1\end{array}$ & $\begin{array}{l}129.8 \\
139.9 \\
150.0 \\
160.0 \\
170.2\end{array}$ & $\begin{array}{l}130.8 \\
140.9 \\
151.0 \\
161.0 \\
171.2\end{array}$ \\
\hline $\begin{array}{l}200 \\
210 \\
220 \\
230 \\
240\end{array}$ & $\begin{array}{l}172.2 \\
182.4 \\
192.6 \\
202.9 \\
213.3\end{array}$ & $\begin{array}{l}173.2 \\
183.5 \\
193.6 \\
203.9 \\
214.4\end{array}$ & $\begin{array}{l}174.3 \\
184.5 \\
194.7 \\
205.0 \\
215.4\end{array}$ & $\begin{array}{l}175.3 \\
185.5 \\
195.7 \\
206.0 \\
216.5\end{array}$ & $\begin{array}{l}176.3 \\
186.5 \\
196.7 \\
207.1 \\
217.6\end{array}$ & $\begin{array}{l}177.3 \\
187.5 \\
197.7 \\
208.1 \\
218.6\end{array}$ & $\begin{array}{l}178.4 \\
188.5 \\
198.8 \\
209.1 \\
219.7\end{array}$ & $\begin{array}{l}179.4 \\
189.6 \\
199.8 \\
210.2 \\
220.7\end{array}$ & $\begin{array}{l}180.4 \\
190.6 \\
200.8 \\
211.2 \\
221.8\end{array}$ & $\begin{array}{l}181.4 \\
191 \cdot 6 \\
201 \cdot 9 \\
212 \cdot 3 \\
222.9\end{array}$ \\
\hline $\begin{array}{l}250 \\
260 \\
270 \\
280\end{array}$ & $\begin{array}{l}223.9 \\
234.6 \\
244.9 \\
255.2 \\
266.1\end{array}$ & $\begin{array}{l}225.0 \\
235.6 \\
245.9 \\
256.2 \\
267.2\end{array}$ & $\begin{array}{l}226.1 \\
236.6 \\
246.9 \\
257.3 \\
268.3\end{array}$ & $\begin{array}{l}227.1 \\
237.7 \\
247.9 \\
258.4 \\
269.4\end{array}$ & $\begin{array}{l}228.2 \\
238.7 \\
248.9 \\
259.5\end{array}$ & $\begin{array}{l}229.3 \\
239.7 \\
250.0 \\
260.6\end{array}$ & $\begin{array}{l}230.3 \\
240.7 \\
251.0 \\
261.7\end{array}$ & $\begin{array}{l}231.4 \\
241.8 \\
252.0 \\
262.8\end{array}$ & $\begin{array}{l}232.5 \\
242.8 \\
253.1 \\
263.9\end{array}$ & $\begin{array}{l}233.5 \\
243.8 \\
254.1 \\
265.0\end{array}$ \\
\hline
\end{tabular}

TABLB GEIERATBD ON 92/05/26. 
FROM:

G-TABLB

AUG 24, 1981
N-TABLE

INST. 79

AUG 25, 1981

VERSION: RI

NC TABLB

\begin{tabular}{|c|c|c|c|c|c|c|c|c|c|c|}
\hline $\mathbf{R}$ & 0 & 1 & 2 & 3 & 4 & 5 & 6 & 7 & 8 & \\
\hline $\begin{array}{r}0 \\
10 \\
20 \\
30 \\
40\end{array}$ & $\begin{array}{r}-31.1 \\
-19.6 \\
-7.8 \\
3.5 \\
14.1\end{array}$ & $\begin{array}{r}-29.9 \\
-18.4 \\
-6.6 \\
4.6 \\
15.1\end{array}$ & $\begin{array}{r}-28.8 \\
-17.2 \\
-5.5 \\
5.7 \\
16.1\end{array}$ & $\begin{array}{r}-27.6 \\
-16.0 \\
-4.3 \\
6.8 \\
17.1\end{array}$ & $\begin{array}{r}-26.5 \\
-14.9 \\
-3.2 \\
7.9 \\
18.1\end{array}$ & $\begin{array}{r}-25.3 \\
-13.7 \\
-2.0 \\
8.9 \\
19.1\end{array}$ & $\begin{array}{r}-24.2 \\
-12.5 \\
-.9 \\
10.0 \\
20.1\end{array}$ & $\begin{array}{r}-23.0 \\
-11.3 \\
.2 \\
11.1 \\
21.0\end{array}$ & $\begin{array}{r}-21.9 \\
-10.1 \\
1.3 \\
12.1 \\
22.0\end{array}$ & $\begin{array}{r}-20.7 \\
-9.0 \\
2.4 \\
13.1 \\
23.0\end{array}$ \\
\hline $\begin{array}{l}50 \\
60 \\
70 \\
80 \\
90\end{array}$ & $\begin{array}{l}23.9 \\
33.2 \\
42.3 \\
51.6 \\
61.0\end{array}$ & $\begin{array}{l}24.9 \\
34.1 \\
43.2 \\
52.5 \\
62.0\end{array}$ & $\begin{array}{l}25.8 \\
35.0 \\
44.2 \\
53.4 \\
63.0\end{array}$ & $\begin{array}{l}26.7 \\
35.9 \\
45.1 \\
54.4 \\
63.9\end{array}$ & $\begin{array}{l}27.7 \\
36.8 \\
46.0 \\
55.3 \\
64.9\end{array}$ & $\begin{array}{l}28.6 \\
37.7 \\
46.9 \\
56.3 \\
65.9\end{array}$ & $\begin{array}{l}29.6 \\
38.7 \\
47.8 \\
57.2 \\
66.9\end{array}$ & $\begin{array}{l}30.5 \\
39.6 \\
48.8 \\
58.2 \\
67.9\end{array}$ & $\begin{array}{l}31.4 \\
40.5 \\
49.7 \\
59.1 \\
68.9\end{array}$ & $\begin{array}{l}32.3 \\
41.4 \\
50.6 \\
60.1 \\
69.8\end{array}$ \\
\hline $\begin{array}{l}00 \\
10 \\
20 \\
30 \\
40\end{array}$ & $\begin{array}{r}70.8 \\
80.8 \\
90.9 \\
101.0 \\
111.0\end{array}$ & $\begin{array}{r}71.8 \\
81.8 \\
91.9 \\
102.0 \\
112.0\end{array}$ & $\begin{array}{r}72.8 \\
82.8 \\
92.9 \\
103.0 \\
113.0\end{array}$ & $\begin{array}{r}73.8 \\
83.8 \\
93.9 \\
104.0 \\
114.0\end{array}$ & $\begin{array}{r}74 \\
84 \\
94 \\
105 \\
115\end{array}$ & $\begin{array}{r}75.8 \\
85.9 \\
95.9 \\
106.0 \\
116.0\end{array}$ & $\begin{array}{r}76.8 \\
86.9 \\
96.9 \\
107.0 \\
117.0\end{array}$ & $\begin{array}{r}77.8 \\
87.9 \\
98.0 \\
108.0 \\
117.9\end{array}$ & $\begin{array}{r}78.8 \\
88.9 \\
99.0 \\
109.0 \\
118.9\end{array}$ & $\begin{array}{r}79 \\
89 \\
100 \\
110 \\
119\end{array}$ \\
\hline $\begin{array}{l}50 \\
60 \\
70 \\
80 \\
90\end{array}$ & $\begin{array}{l}120.9 \\
130.9 \\
140.7 \\
150.6 \\
160.6\end{array}$ & $\begin{array}{l}121.9 \\
131.9 \\
141.7 \\
151.6 \\
161.6\end{array}$ & $\begin{array}{l}122.9 \\
132.9 \\
142.7 \\
152.6 \\
162.6\end{array}$ & $\begin{array}{l}123.9 \\
133.8 \\
143.7 \\
153.6 \\
163.6\end{array}$ & $\begin{array}{l}124 \\
134 \\
144 \\
154 \\
164\end{array}$ & $\begin{array}{l}125.9 \\
135.8 \\
145.7 \\
155.6 \\
165.6\end{array}$ & $\begin{array}{l}126.9 \\
136.8 \\
146.6 \\
156.6 \\
166.6\end{array}$ & $\begin{array}{l}127.9 \\
137.8 \\
147.6 \\
157.6 \\
167.6\end{array}$ & $\begin{array}{l}128.9 \\
138.8 \\
148.6 \\
158.6 \\
168.6\end{array}$ & $\begin{array}{l}129.9 \\
139.7 \\
149.6 \\
159.6 \\
169.6\end{array}$ \\
\hline $\begin{array}{l}200 \\
210 \\
220 \\
230 \\
240\end{array}$ & $\begin{array}{l}170.6 \\
180.6 \\
190.7 \\
200.7 \\
211.0\end{array}$ & $\begin{array}{l}171.6 \\
181.6 \\
191.7 \\
201.8 \\
212.0\end{array}$ & $\begin{array}{l}172.6 \\
182.7 \\
192.7 \\
202.8 \\
213.1\end{array}$ & $\begin{array}{l}173.6 \\
183.7 \\
193.7 \\
203.8 \\
214.1\end{array}$ & $\begin{array}{l}174.6 \\
184.7 \\
194.7 \\
204.8 \\
215.2\end{array}$ & $\begin{array}{l}175.6 \\
185.7 \\
195.7 \\
205.8 \\
216.2\end{array}$ & $\begin{array}{l}176.6 \\
186.7 \\
196.7 \\
206.9 \\
217.3\end{array}$ & $\begin{array}{l}177.6 \\
187.7 \\
197.7 \\
207.9 \\
218.3\end{array}$ & $\begin{array}{l}178.6 \\
188.7 \\
198.7 \\
208.9 \\
219.4\end{array}$ & $\begin{array}{l}179.6 \\
189.7 \\
199.7 \\
210.0 \\
220.4\end{array}$ \\
\hline $\begin{array}{l}250 \\
260 \\
270 \\
280\end{array}$ & $\begin{array}{l}221.4 \\
231.8 \\
242.0 \\
252.2 \\
262.9\end{array}$ & $\begin{array}{l}222.5 \\
232.8 \\
243.0 \\
253.3 \\
264.0\end{array}$ & $\begin{array}{l}223.5 \\
233.9 \\
244.0 \\
254.3 \\
265.2\end{array}$ & $\begin{array}{l}224.6 \\
234.9 \\
245.1 \\
255.4 \\
266.3\end{array}$ & $\begin{array}{l}225.6 \\
235.9 \\
246.1 \\
256.4 \\
267.4\end{array}$ & $\begin{array}{l}22 \\
23 \\
24 \\
25 \\
26\end{array}$ & $\begin{array}{l}227.7 \\
237.9 \\
248.1 \\
258.6 \\
269.6\end{array}$ & $\begin{array}{l}228.7 \\
239.0 \\
249.1 \\
259.7\end{array}$ & $\begin{array}{l}229.7 \\
240.0 \\
250.2 \\
260.8\end{array}$ & $\begin{array}{l}230.8 \\
241.0 \\
251.2 \\
261.9\end{array}$ \\
\hline
\end{tabular}

TABLB GBNBRATBD ON $92 / 05 / 26$. 
FROM:

N-TABLB

G-TABLB

AUG 24, 1981

INST. 79

AUG 25, 1981

VERSION: RI

ND TABLE

\begin{tabular}{|c|c|c|c|c|c|c|c|c|c|c|}
\hline $\mathbf{R}$ & 0 & 1 & 2 & 3 & 4 & 5 & 6 & 7 & 8 & 3 \\
\hline $\begin{array}{l}0 \\
10 \\
20 \\
30 \\
40\end{array}$ & $\begin{array}{r}-33.4 \\
-21.9 \\
-10.5 \\
.6 \\
11.1\end{array}$ & $\begin{array}{r}-32.2 \\
-20.8 \\
-9.4 \\
1.6 \\
12.1\end{array}$ & $\begin{array}{r}-31.1 \\
-19.6 \\
-8.3 \\
2.7 \\
13.1\end{array}$ & $\begin{array}{r}-29.9 \\
-18.5 \\
-7.2 \\
3.8 \\
14.1\end{array}$ & $\begin{array}{r}-28.8 \\
-17.4 \\
-6.1 \\
4.9 \\
15.1\end{array}$ & $\begin{array}{r}-27.6 \\
-16.2 \\
-5.0 \\
5.9 \\
16.0\end{array}$ & $\begin{array}{r}-26.5 \\
-15.1 \\
-3.8 \\
7.0 \\
17.0\end{array}$ & $\begin{array}{r}-25.4 \\
-14.0 \\
-2.7 \\
8.1 \\
18.0\end{array}$ & $\begin{array}{r}-24.2 \\
-12.8 \\
-1.6 \\
9.1 \\
18.9\end{array}$ & $\begin{array}{r}-23.1 \\
-11.7 \\
-.5 \\
10.1 \\
19.9\end{array}$ \\
\hline $\begin{array}{l}50 \\
60 \\
70 \\
80 \\
90\end{array}$ & $\begin{array}{l}20.9 \\
30.2 \\
39.5 \\
48.8 \\
58.3\end{array}$ & $\begin{array}{l}21.8 \\
31.2 \\
40.4 \\
49.7 \\
59.3\end{array}$ & $\begin{array}{l}22.7 \\
32.1 \\
41.3 \\
50.7 \\
60.2\end{array}$ & $\begin{array}{l}23.7 \\
33.0 \\
42.3 \\
51.6 \\
61.2\end{array}$ & $\begin{array}{l}24.6 \\
33.9 \\
43.2 \\
52.6 \\
62.2\end{array}$ & $\begin{array}{l}25.6 \\
34.9 \\
44.1 \\
53.5 \\
63.1\end{array}$ & $\begin{array}{l}26.5 \\
35.8 \\
45.1 \\
54.5 \\
64.1\end{array}$ & $\begin{array}{l}27.4 \\
36.7 \\
46.0 \\
55.4 \\
65.1\end{array}$ & $\begin{array}{l}28.4 \\
37.6 \\
46.9 \\
56.4 \\
66.1\end{array}$ & $\begin{array}{l}29.3 \\
38.6 \\
47.9 \\
57.3 \\
67.1\end{array}$ \\
\hline $\begin{array}{l}100 \\
110 \\
120 \\
130 \\
140\end{array}$ & $\begin{array}{r}68.1 \\
78.0 \\
88.0 \\
98.0 \\
107.9\end{array}$ & $\begin{array}{r}69.1 \\
79.0 \\
89.0 \\
99.0 \\
108.9\end{array}$ & $\begin{array}{r}70.1 \\
80.0 \\
90.0 \\
100.0 \\
109.9\end{array}$ & $\begin{array}{r}71.0 \\
81.0 \\
91.0 \\
101.0 \\
110.9\end{array}$ & $\begin{array}{r}72.0 \\
82.0 \\
92.0 \\
102.0 \\
111.9\end{array}$ & $\begin{array}{r}73.0 \\
83.0 \\
93.0 \\
103.0 \\
112.9\end{array}$ & $\begin{array}{r}74.0 \\
84.0 \\
94.0 \\
104.0 \\
113.9\end{array}$ & $\begin{array}{r}75.0 \\
85.0 \\
95.0 \\
105.0 \\
114.8\end{array}$ & $\begin{array}{r}76.0 \\
86.0 \\
96.0 \\
106.0 \\
115.8\end{array}$ & $\begin{array}{r}77.0 \\
87.0 \\
97.0 \\
107.0 \\
116.8\end{array}$ \\
\hline $\begin{array}{l}150 \\
160 \\
170 \\
180 \\
190\end{array}$ & $\begin{array}{l}117.8 \\
127.6 \\
137.3 \\
147.1 \\
156.9\end{array}$ & $\begin{array}{l}118.8 \\
128.6 \\
138.3 \\
148.0 \\
157.9\end{array}$ & $\begin{array}{l}119.8 \\
129.5 \\
139.3 \\
149.0 \\
158.9\end{array}$ & $\begin{array}{l}120.7 \\
130.5 \\
140.2 \\
150.0 \\
159.8\end{array}$ & $\begin{array}{l}121.7 \\
131.5 \\
141.2 \\
151.0 \\
160.8\end{array}$ & $\begin{array}{l}122.7 \\
132.4 \\
142.2 \\
152.0 \\
161.8\end{array}$ & $\begin{array}{l}123.7 \\
133.4 \\
143.2 \\
153.0 \\
162.8\end{array}$ & $\begin{array}{l}124.6 \\
134.4 \\
144.1 \\
154.0 \\
163.8\end{array}$ & $\begin{array}{l}125.6 \\
135.4 \\
145.1 \\
154.9 \\
164.8\end{array}$ & $\begin{array}{l}126.6 \\
136.3 \\
146.1 \\
155.9 \\
165.8\end{array}$ \\
\hline $\begin{array}{l}200 \\
210 \\
220 \\
230 \\
240\end{array}$ & $\begin{array}{l}166.8 \\
176.8 \\
186.7 \\
196.7 \\
206.8\end{array}$ & $\begin{array}{l}167.8 \\
177.8 \\
187.7 \\
197.7 \\
207.8\end{array}$ & $\begin{array}{l}168.8 \\
178.8 \\
188.7 \\
198.7 \\
208.8\end{array}$ & $\begin{array}{l}169.8 \\
179.8 \\
189.7 \\
199.7 \\
209.8\end{array}$ & $\begin{array}{l}170.8 \\
180.8 \\
190.7 \\
200.7 \\
210.9\end{array}$ & $\begin{array}{l}171.8 \\
181.8 \\
191.7 \\
201.7 \\
211.9\end{array}$ & $\begin{array}{l}172.8 \\
182.8 \\
192.7 \\
202.7 \\
212.9\end{array}$ & $\begin{array}{l}173.8 \\
183.8 \\
193.7 \\
203.8 \\
213.9\end{array}$ & $\begin{array}{l}174.8 \\
184.8 \\
194.7 \\
204.8 \\
214.9\end{array}$ & $\begin{array}{l}175.8 \\
185.8 \\
195.7 \\
205.8 \\
216.0\end{array}$ \\
\hline $\begin{array}{l}250 \\
260 \\
270 \\
280\end{array}$ & $\begin{array}{l}217 \cdot 0 \\
227.3 \\
237.4 \\
247.4 \\
258.1\end{array}$ & $\begin{array}{l}218.0 \\
228.3 \\
238.4 \\
248.4 \\
259.2\end{array}$ & $\begin{array}{l}219.0 \\
229.3 \\
239.4 \\
249.4 \\
260.3\end{array}$ & $\begin{array}{l}220.1 \\
230.3 \\
240.4 \\
250.5 \\
261.5\end{array}$ & $\begin{array}{l}221.1 \\
231.3 \\
241.4 \\
251.6 \\
262.6\end{array}$ & $\begin{array}{l}222.1 \\
232.4 \\
242.4 \\
252.6 \\
263.7\end{array}$ & $\begin{array}{l}223.2 \\
233.4 \\
243.4 \\
253.7 \\
264.8\end{array}$ & $\begin{array}{l}224.2 \\
234.4 \\
244.4 \\
254.8 \\
265.9\end{array}$ & $\begin{array}{l}225.2 \\
235.4 \\
245.4 \\
255.9 \\
267.1\end{array}$ & $\begin{array}{l}226.2 \\
236.4 \\
246.4 \\
257.0\end{array}$ \\
\hline
\end{tabular}

TABLB GENERATBD ON 92/05/26. 
INST. NO:

79

DATE: A.q. 25,1981 RI

REFERENCE STANDARD LAMP DATA

\begin{tabular}{|c|c|c|c|c|c|c|c|}
\hline \multirow[b]{2}{*}{ Lamp No. } & \multicolumn{2}{|c|}{ Voltage } & \multirow{2}{*}{$\frac{\text { Current }}{\text { amps }}$} & \multirow{2}{*}{${ }_{A}^{R}$} & \multirow{2}{*}{${ }^{R} \mathrm{C}$} & \multirow{2}{*}{${ }^{R}{ }^{R}}$. & \multirow{2}{*}{${ }_{D}^{R}$} \\
\hline & d.c. & a.c. & & & & & \\
\hline 79 Q 1 & 24.00 & & & 37.5 & $\begin{array}{r}16.6 \\
42.5\end{array}$ & $\begin{array}{l}41.8 \\
67.4\end{array}$ & $\begin{array}{r}17.8 \\
46.8\end{array}$ \\
\hline $79 Q 2$ & 24.00 & & & $\begin{array}{r}22.6 \\
38.0\end{array}$ & $\begin{array}{r}7.1 \\
43.0\end{array}$ & $\begin{array}{r}41.3 \\
68.9\end{array}$ & $\begin{array}{l}18.3 \\
47.3^{18}\end{array}$ \\
\hline $79 Q 3$ & 24.00 & & & 37.9 & $\begin{array}{l}17.0 \\
42.9^{\circ}\end{array}$ & $\begin{array}{l}44.0 \\
68.5\end{array}$ & $\begin{array}{r}18.1 \\
47.1\end{array}$ \\
\hline UQI & 24.00 & & & $\begin{array}{r}13.9 \\
39.3\end{array}$ & $\begin{array}{r}18.2 \\
44.1\end{array}$ & $\begin{array}{l}39.0 \\
66.3\end{array}$ & $\begin{array}{r}19.5 \\
48.6\end{array}$ \\
\hline$U Q 2$ & 24.00 & & & $38.8^{13.4}$ & $43.7^{17.8}$ & $\begin{array}{r}39.3 \\
66.7\end{array}$ & $\begin{array}{r}19.1 \\
48.2\end{array}$ \\
\hline$\cup 43$ & 24.00 & & & 38.0 & $\begin{array}{r}16.8 \\
42.7\end{array}$ & $\begin{array}{c}40.8 \\
68.3\end{array}$ & $\begin{array}{r}18.2 \\
47.2\end{array}$ \\
\hline$R / 2$ & 24.00 & & & 37.7 & 42.8 & 67.9 & 46.8 \\
\hline$R 13$ & 24.00 & & & 38.0 & 42.8 & 67.9 & 47.3 \\
\hline $79 C^{*}$ & & 100.0 & & 47.8 & 51.5 & $\begin{array}{r}31.0 \\
57.5\end{array}$ & $\begin{array}{c}257 \\
55.1\end{array}$ \\
\hline $790^{\circ}$ & & 100.0 & & 48.6 & 51.7 & & $55^{25.8}$ \\
\hline TES : & 7 & $h: g$ & $d \subset c$ & & & & \\
\hline
\end{tabular}




\section{DOBSON OZONE SPECTROPHOTOMETER CALIBRATION}

$$
\text { Place: Boulder, Colol ato }
$$

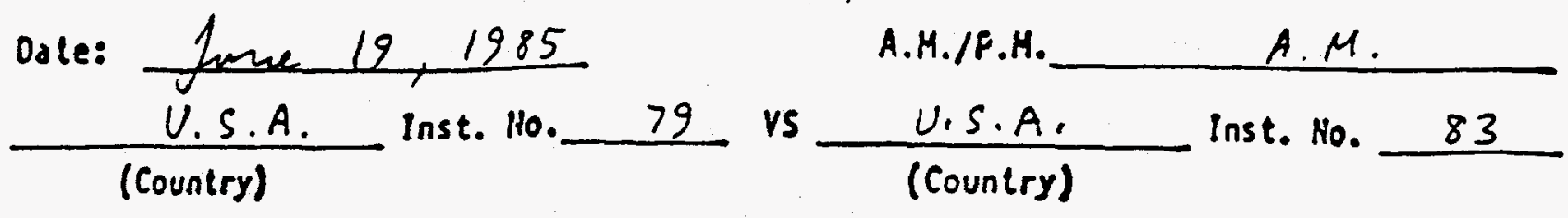

For instrument No. 79 use $N$ tables dated $\log 25,1981 R 1$ Apply the following corrections to the tables:

To $\mathrm{Gh}$ or $\mathrm{HA}$ values add

To GC or NC values add

$+1.0$

To GD or NO values add

$\frac{+1.0}{+1.0}$

For instrument No. 83 use $N$ tobles dated Amqust 26, 1976 FI Apply the following corrections to the tables:

To $G A$ or MA values add

To GC or NC values add

To GO or NO values add

$\frac{+4.1}{+4.5}$

Nores: "Final" calibuation with instrument 25 received from Nashville. Cobalt filter was found to be corroded. 


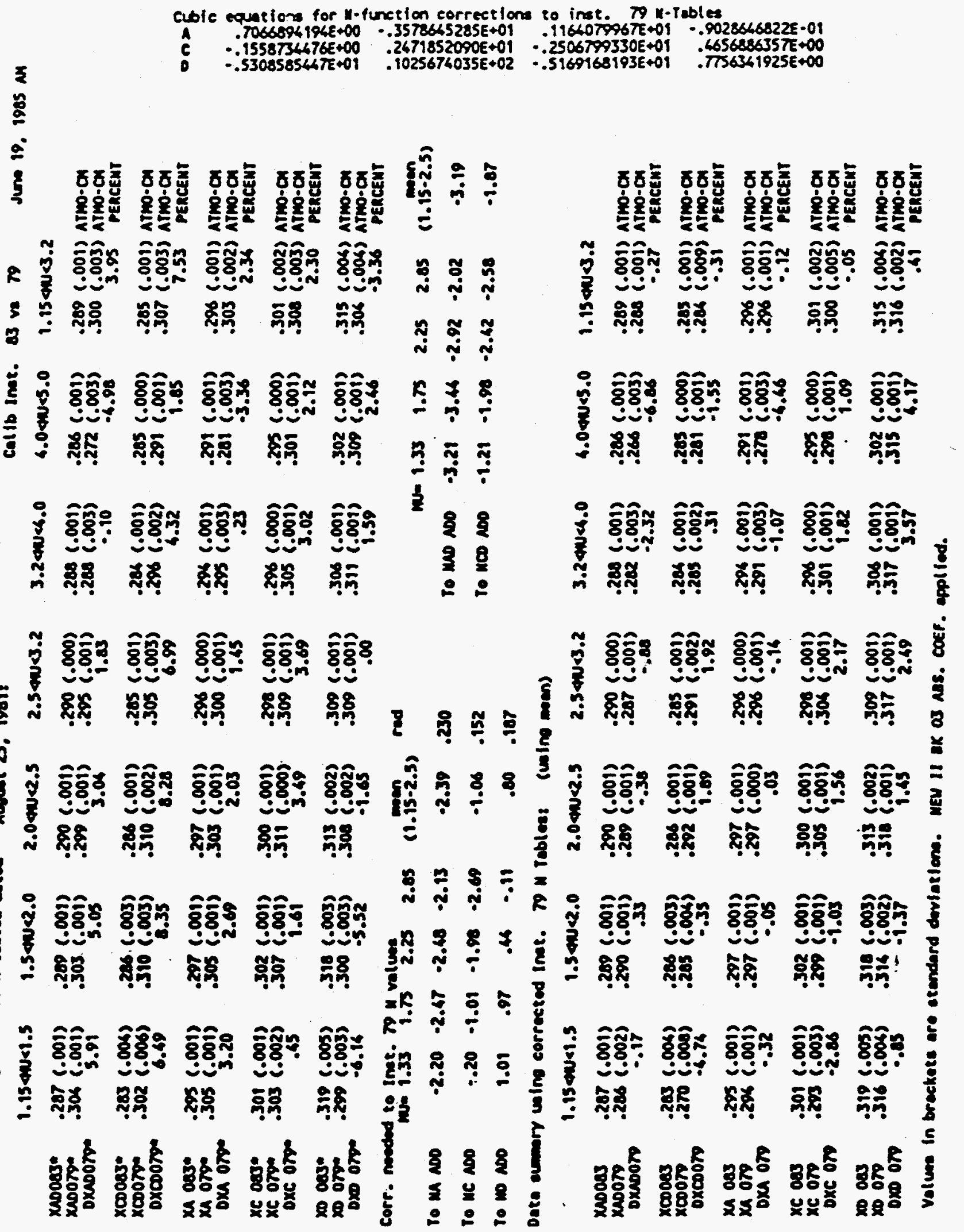



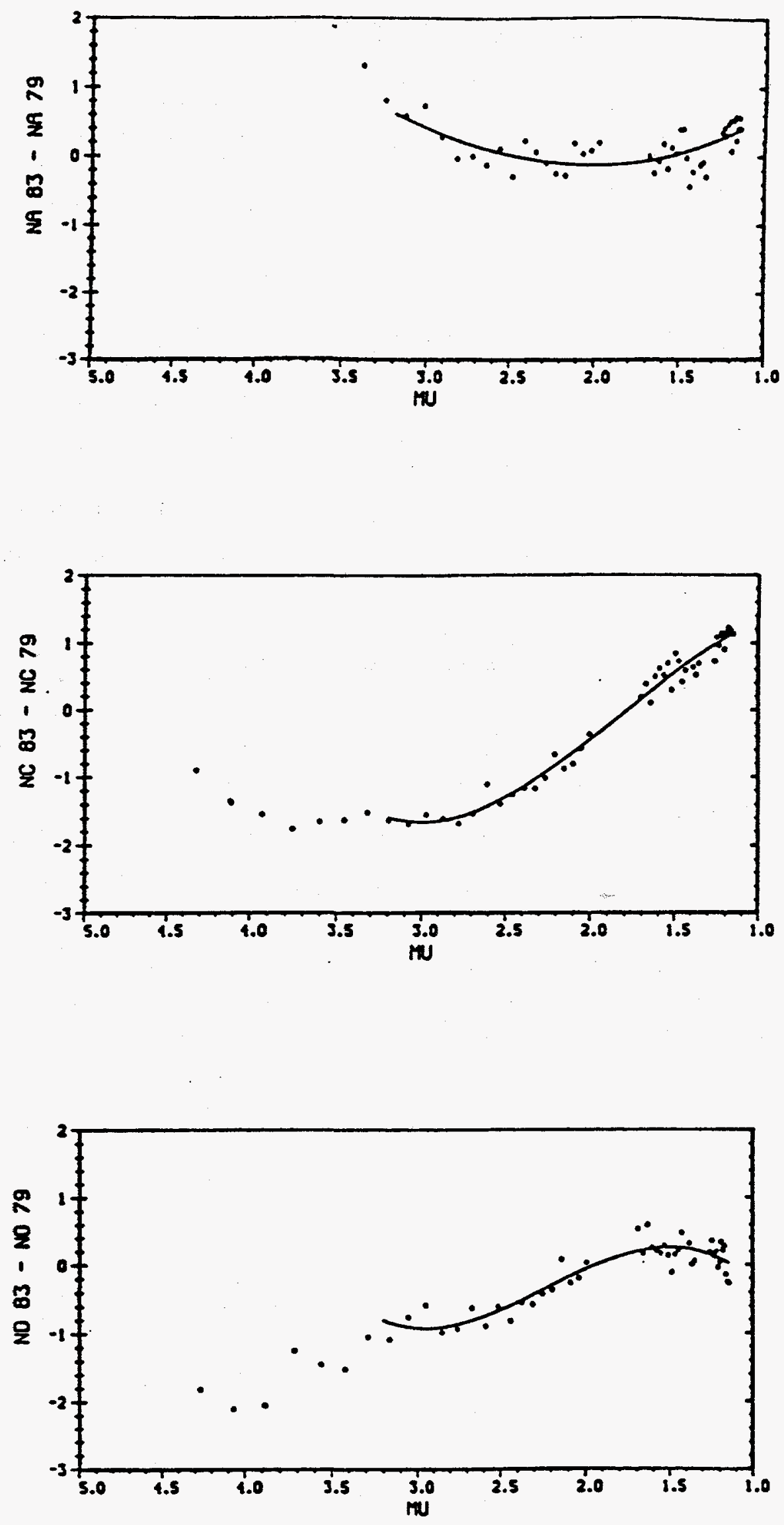

$I I-61$ 
DOBSON INSTRUMENT 79 SAMPLE CALIBRATION DATA SEPTEMBER 10, 1975 AND AUGUST 14, 1981

(a) Unstable optical wedge.

(b) Observations are $\mu$-dependent.

(c) Change in instrument optical characteristics occurred also due to cobalt filter corrosion. 


\section{DOBSON OZONE SPECTROPHOTOMETER CALIBRATION}

Place: Boulder. Colorado

\begin{tabular}{|c|c|c|c|c|c|c|c|}
\hline \multirow[t]{2}{*}{ Oale: } & Sept. 10 & 1975 & & \multirow[b]{2}{*}{ vs } & \multicolumn{3}{|c|}{ A.M./F.M. A.M. } \\
\hline & $U \cdot S \cdot A$. & Inst. No. & 79 & & U.S.A. & Inst. No. & 83 \\
\hline
\end{tabular}

For instrument Ho. 79 use $G$ tables dated September 9, 1975 Apply the following corrections to the tables:

To oh or MA values add

$\frac{N A}{N A} \frac{N A}{N A}$

To GC or NC values add

To CD or NO values add

For instrument Ho. 83 use $-N$ tables dated August 26, $1976 \mathrm{FI}$ Apply the following corrections to the tables:

To Gh or MA values add

To GC or NC values add

To GO or ND values add

$\frac{-0.5}{-0.4}$

notes: "Initial" calibration. 
INST. NO. 79

SBPTEABBR 09, 1975

GA TABLB

\begin{tabular}{|c|c|c|c|c|c|c|c|c|c|c|}
\hline $\mathbf{R}$ & 0 & 1 & 2 & 3 & 4 & 5 & 6 & 7 & 8 & \\
\hline $\begin{array}{r}0 \\
10 \\
20 \\
30 \\
40\end{array}$ & $\begin{array}{r}5.7 \\
17.7 \\
29.4 \\
10.2\end{array}$ & $\begin{array}{r}6.9 \\
18.9 \\
30.5 \\
41.2\end{array}$ & $\begin{array}{r}8.0 \\
20.1 \\
31.6 \\
42.3\end{array}$ & $\begin{array}{r}9.2 \\
21.3 \\
32.7 \\
43.3\end{array}$ & $\begin{array}{l}10.4 \\
22.5 \\
33.8 \\
44.3\end{array}$ & $\begin{array}{l}.0 \\
11.6 \\
23.7 \\
34.9 \\
45.3\end{array}$ & $\begin{array}{r}1.1 \\
12.8 \\
24.9 \\
36.0 \\
46.3\end{array}$ & $\begin{array}{r}2.3 \\
14.0 \\
26.0 \\
37.0 \\
47.3\end{array}$ & $\begin{array}{r}3.4 \\
15.2 \\
27.1 \\
38.1 \\
48.4\end{array}$ & $\begin{array}{r}4.5 \\
16.4 \\
28.2 \\
39.1 \\
49.3\end{array}$ \\
\hline $\begin{array}{l}50 \\
60 \\
70 \\
80 \\
90\end{array}$ & $\begin{array}{l}50.3 \\
59.8 \\
68.9 \\
78.3 \\
88.2\end{array}$ & $\begin{array}{l}51.3 \\
60.7 \\
69.9 \\
79.3 \\
89.2\end{array}$ & $\begin{array}{l}52.3 \\
61.6 \\
70.8 \\
80.3 \\
90.2\end{array}$ & $\begin{array}{l}53.3 \\
62.5 \\
71.7 \\
81.2 \\
91.2\end{array}$ & $\begin{array}{l}54.2 \\
63.4 \\
72.6 \\
82.2 \\
92.2\end{array}$ & $\begin{array}{l}55.2 \\
64.3 \\
73.6 \\
83.2 \\
93.2\end{array}$ & $\begin{array}{l}56.1 \\
65.2 \\
74.5 \\
84.2 \\
94.2\end{array}$ & $\begin{array}{l}57.0 \\
66.1 \\
75.5 \\
85.2 \\
95.3\end{array}$ & $\begin{array}{l}57.9 \\
67.1 \\
76.4 \\
86.2 \\
96.3\end{array}$ & $\begin{array}{l}58.9 \\
68.0 \\
77.4 \\
87.2 \\
97.3\end{array}$ \\
\hline $\begin{array}{l}100 \\
110 \\
120 \\
130 \\
140\end{array}$ & $\begin{array}{r}98.3 \\
108.5 \\
118.7 \\
129.0 \\
139.2\end{array}$ & $\begin{array}{r}99.3 \\
109.5 \\
119.8 \\
130.1 \\
140.2\end{array}$ & $\begin{array}{l}100.3 \\
110.5 \\
120.8 \\
131.1 \\
141.2\end{array}$ & $\begin{array}{l}101.4 \\
111.5 \\
121.8 \\
132.1 \\
142.2\end{array}$ & $\begin{array}{l}102.4 \\
112.6 \\
122.9 \\
133.1 \\
143.2\end{array}$ & $\begin{array}{l}103.4 \\
113.6 \\
123.9 \\
134.1 \\
144.3\end{array}$ & $\begin{array}{l}104 \\
114 \\
124 \\
135 \\
145\end{array}$ & $\begin{array}{l}5.4 \\
5.6 \\
6.0 \\
6.2 \\
6.3\end{array}$ & $\begin{array}{l}106.4 \\
116.7 \\
127.0 \\
137.2 \\
147.3\end{array}$ & $\begin{array}{l}107.5 \\
117.7 \\
128.0 \\
138.2 \\
148.3\end{array}$ \\
\hline $\begin{array}{l}150 \\
160 \\
70 \\
80 \\
90\end{array}$ & $\begin{array}{l}149.4 \\
159.6 \\
169.7 \\
179.9 \\
190.3\end{array}$ & $\begin{array}{l}150.4 \\
160.6 \\
170.7 \\
181.0 \\
191.4\end{array}$ & $\begin{array}{l}151.4 \\
161.6 \\
271.7 \\
182.0 \\
192.4\end{array}$ & $\begin{array}{l}152.4 \\
162.6 \\
172.7 \\
183.1 \\
193.4\end{array}$ & $\begin{array}{l}153.5 \\
163.6 \\
173.8 \\
184.1 \\
194.5\end{array}$ & $\begin{array}{l}154.5 \\
164.6 \\
174.8 \\
185.1 \\
195.5\end{array}$ & $\begin{array}{l}155.5 \\
165.7 \\
175.8 \\
186.2 \\
196.6\end{array}$ & $\begin{array}{l}156.5 \\
166.7 \\
176.8 \\
187.2 \\
197.6\end{array}$ & $\begin{array}{l}157.5 \\
167.7 \\
177.9 \\
188.2 \\
198.6\end{array}$ & $\begin{array}{l}158.6 \\
168.7 \\
178.9 \\
189.3 \\
199.7\end{array}$ \\
\hline $\begin{array}{l}200 \\
210 \\
220 \\
230\end{array}$ & $\begin{array}{l}200.7 \\
211.2 \\
221.6 \\
231.9 \\
242.3\end{array}$ & $\begin{array}{l}201.7 \\
212.2 \\
222.7 \\
233.0 \\
243.4\end{array}$ & $\begin{array}{l}202.8 \\
213.3 \\
223.7 \\
234.0 \\
244.4\end{array}$ & $\begin{array}{l}203.8 \\
214.3 \\
224.7 \\
235.0 \\
245.5\end{array}$ & $\begin{array}{l}204.8 \\
215.4 \\
225.8 \\
236.1 \\
246.5\end{array}$ & $\begin{array}{l}205.9 \\
216.4 \\
226.8 \\
237.1 \\
247.5\end{array}$ & $\begin{array}{l}206.9 \\
217.5 \\
227.8 \\
238.2 \\
248.6\end{array}$ & $\begin{array}{l}208.0 \\
218.5 \\
228.9 \\
239.2 \\
249.6\end{array}$ & $\begin{array}{l}209.1 \\
219.5 \\
229.9 \\
240.2 \\
250.7\end{array}$ & $\begin{array}{l}210.1 \\
220.6 \\
230.9 \\
241.3 \\
251.7\end{array}$ \\
\hline $\begin{array}{l}50 \\
260 \\
270 \\
280\end{array}$ & $\begin{array}{l}252.8 \\
263.1 \\
273.4 \\
283.8 \\
294.5\end{array}$ & $\begin{array}{l}253.8 \\
264.1 \\
274.4 \\
284.8 \\
295.6\end{array}$ & $\begin{array}{l}254.9 \\
265.1 \\
275.4 \\
285.9 \\
296.8\end{array}$ & $\begin{array}{l}255.9 \\
266.2 \\
276.5 \\
287.0 \\
297.9\end{array}$ & $\begin{array}{l}256.9 \\
267.2 \\
277.5 \\
288.0 \\
299.1\end{array}$ & $\begin{array}{l}258.0 \\
268.2 \\
278.6 \\
289.1 \\
300.2\end{array}$ & $\begin{array}{l}259.0 \\
269.3 \\
279.6 \\
290.2\end{array}$ & $\begin{array}{l}260.0 \\
270.3 \\
280.6 \\
291.3\end{array}$ & $\begin{array}{l}261.0 \\
271.3 \\
281.7 \\
292.4\end{array}$ & $\begin{array}{l}262.1 \\
272.3 \\
282.7 \\
293.4\end{array}$ \\
\hline
\end{tabular}

TRPUT DATA:

$\begin{array}{lllllllll}25.82 & 25.65 & 25.83 & 26.40 & 27.41 & 28.53 & 29.68 & 30.75 \\ 31.52 & 32.00 & 32.24 & 32.17 & 31.70 & 31.18 & 30.69 & 30.28 \\ 29.96 & 29.72 & 29.56 & 29.14 & 29.38 & 29.37 & 29.38 & 29.43 \\ 29.48 & 29.53 & 29.57 & 29.59 & 29.60 & 29.59 & 29.54 & 29.47 \\ 29.38 & 29.27 & 29.14 & 29.03 & 28.94 & 28.88 & 28.84 & 28.84 \\ 28.88 & 28.93 & 28.98 & 29.01 & 29.00 & 28.98 & 28.97 & 29.01 \\ 29.09 & 29.14 & 29.15 & 29.05 & 28.81 & 28.42 & 27.81 & \end{array}$


INST. NO. 79

SBPTRABBR 09, 1975

GC TABLB

\begin{tabular}{|c|c|c|c|c|c|c|c|c|c|c|}
\hline$R$ & 0 & 1 & 2 & 3 & 4 & 5 & 6 & 7 & 8 & 9 \\
\hline $\begin{array}{r}0 \\
10 \\
20 \\
30 \\
40\end{array}$ & $\begin{array}{r}5.7 \\
17.5 \\
28.8 \\
39.7\end{array}$ & $\begin{array}{r}6.8 \\
18.7 \\
29.9 \\
40.7\end{array}$ & $\begin{array}{r}8.0 \\
19.8 \\
31.0 \\
41.8\end{array}$ & $\begin{array}{r}9.2 \\
21.0 \\
32.1 \\
42.8\end{array}$ & $\begin{array}{l}10.4 \\
22.1 \\
33.2 \\
43.8\end{array}$ & $\begin{array}{l}.0 \\
11.6 \\
23.3 \\
34.3 \\
44.8\end{array}$ & $\begin{array}{l}1.1 \\
12.8 \\
24.4 \\
35.4 \\
45.8\end{array}$ & $\begin{array}{r}2.3 \\
13.9 \\
25.5 \\
36.5 \\
46.8\end{array}$ & $\begin{array}{r}3.4 \\
15.1 \\
26.6 \\
37.5 \\
47.8\end{array}$ & $\begin{array}{r}4.5 \\
16.3 \\
27.7 \\
38.6 \\
48.8\end{array}$ \\
\hline $\begin{array}{l}50 \\
60 \\
70 \\
80 \\
90\end{array}$ & $\begin{array}{l}49.8 \\
59.2 \\
68.6 \\
78.1 \\
87.9\end{array}$ & $\begin{array}{l}50.8 \\
60.2 \\
69.5 \\
79.1 \\
88.9\end{array}$ & $\begin{array}{l}51.7 \\
61.1 \\
70.5 \\
80.0 \\
89.9\end{array}$ & $\begin{array}{l}52.7 \\
62.0 \\
71.4 \\
81.0 \\
90.9\end{array}$ & $\begin{array}{l}53.6 \\
63.0 \\
72.4 \\
82.0 \\
91.9\end{array}$ & $\begin{array}{l}54.6 \\
63.9 \\
73.3 \\
83.0 \\
92.9\end{array}$ & $\begin{array}{l}55.5 \\
64.8 \\
74.3 \\
84.0 \\
93.9\end{array}$ & $\begin{array}{l}56.5 \\
65.8: \\
75.2 \\
84.9 \\
94.9\end{array}$ & $\begin{array}{r}57.4 \\
: 66.7 \\
76.2 \\
85.9 \\
95.9\end{array}$ & $\begin{array}{l}58.3 \\
67.7 \\
77.1 \\
86.9 \\
96.9\end{array}$ \\
\hline $\begin{array}{l}100 \\
110 \\
120 \\
130 \\
140\end{array}$ & $\begin{array}{r}97.9 \\
108.0 \\
118.2 \\
128.4 \\
138.4\end{array}$ & $\begin{array}{r}98.9 \\
109.0 \\
119.3 \\
129.4 \\
139.4\end{array}$ & $\begin{array}{l}100.0 \\
110.1 \\
120.3 \\
130.4 \\
140.4\end{array}$ & $\begin{array}{l}101.0 \\
111.1 \\
121.3 \\
131.4 \\
141.4\end{array}$ & $\begin{array}{l}102.0 \\
122.1 \\
122.3 \\
132.4 \\
142.4\end{array}$ & $\begin{array}{l}103.0 \\
113.1 \\
123.3 \\
133.4 \\
143.5\end{array}$ & $\begin{array}{l}104.0 \\
114.2 \\
124.3 \\
134.4 \\
144.5\end{array}$ & $\begin{array}{l}105.0 \\
115.2 \\
125.4 \\
135.4\end{array}$ & $\begin{array}{l}106.0 \\
116.2 \\
126.4 \\
136.4 \\
246.5\end{array}$ & $\begin{array}{l}107.0 \\
117.2 \\
127.4 \\
137.4 \\
147.5\end{array}$ \\
\hline $\begin{array}{l}150 \\
160 \\
170 \\
180 \\
190\end{array}$ & $\begin{array}{l}148.5 \\
158.5 \\
168.6 \\
178.8 \\
189.0\end{array}$ & $\begin{array}{l}149.5 \\
159.5 \\
169.6 \\
179.8 \\
190.0\end{array}$ & $\begin{array}{l}150.5 \\
160.5 \\
170.6 \\
180.8 \\
191.0\end{array}$ & $\begin{array}{l}151.5 \\
161.5 \\
171.6 \\
181.8 \\
192.0\end{array}$ & $\begin{array}{l}252.5 \\
162.5 \\
172.6 \\
182.9 \\
193.1\end{array}$ & $\begin{array}{l}153.5 \\
163.5 \\
173.6 \\
183.9 \\
194.1\end{array}$ & $\begin{array}{l}154.5 \\
164.5 \\
174.7 \\
184.9 \\
195.1\end{array}$ & $\begin{array}{l}155.5 \\
165.5 \\
175.7 \\
185.9 \\
196.1\end{array}$ & $\begin{array}{l}156.5 \\
166.6 \\
176.7 \\
186.9 \\
197.2\end{array}$ & $\begin{array}{l}157.5 \\
167.6 \\
177.7 \\
188.0 \\
198.2\end{array}$ \\
\hline $\begin{array}{l}200 \\
210 \\
220 \\
230 \\
240\end{array}$ & $\begin{array}{l}199.2 \\
209.6 \\
219.9 \\
230.0 \\
240.3\end{array}$ & $\begin{array}{l}200.3 \\
210.6 \\
220.9 \\
231.1 \\
241.3\end{array}$ & $\begin{array}{l}201.3 \\
211.7 \\
221.9 \\
232.1 \\
242.3\end{array}$ & $\begin{array}{l}202.3 \\
212.7 \\
222.9 \\
233.1 \\
243.3\end{array}$ & $\begin{array}{l}203.4 \\
213.7 \\
223.9 \\
234.1 \\
244.4\end{array}$ & $\begin{array}{l}204.4 \\
214.7 \\
225.0 \\
235.1 \\
245.4\end{array}$ & $\begin{array}{l}205.4 \\
215.8 \\
226.0 \\
236.2 \\
246.4\end{array}$ & $\begin{array}{l}206.5 \\
216.8 \\
227.0 \\
237.2 \\
247.4\end{array}$ & $\begin{array}{l}207.5 \\
217.8 \\
228.0 \\
238.2 \\
248.5\end{array}$ & $\begin{array}{l}208.6 \\
218.8 \\
229.0 \\
239.2 \\
249.5\end{array}$ \\
\hline $\begin{array}{l}250 \\
260 \\
270 \\
280\end{array}$ & $\begin{array}{l}250.5 \\
260.6 \\
270.8 \\
281.1 \\
291.8\end{array}$ & $\begin{array}{l}251.5 \\
261.6 \\
271.8 \\
282.2 \\
292.9\end{array}$ & $\begin{array}{l}252.6 \\
262.6 \\
272.8 \\
283.2 \\
294.0\end{array}$ & $\begin{array}{l}253.6 \\
263.7 \\
273.9 \\
284.3 \\
205.0\end{array}$ & $\begin{array}{l}254.6 \\
264.7 \\
274.9 \\
285.4\end{array}$ & $\begin{array}{l}255.6 \\
265.7 \\
275.9 \\
286.4\end{array}$ & $\begin{array}{l}256.6 \\
266.7 \\
276.9 \\
287.5\end{array}$ & $\begin{array}{l}257.6 \\
267.7 \\
278.0 \\
288.5\end{array}$ & $\begin{array}{l}258.6 \\
268.7 \\
279.0 \\
289.6\end{array}$ & $\begin{array}{l}259.6 \\
269.8 \\
280.1 \\
290.7\end{array}$ \\
\hline
\end{tabular}

INPUT DATA:

$\begin{array}{llllllll}26.37 & 26.14 & 26.31 & 26.89 & 27.77 & 28.73 & 29.69 & 30.62 \\ 31.28 & 31.76 & 31.90 & 31.77 & 31.43 & 31.08 & 30.75 & 30.14 \\ 30.17 & 29.93 & 29.77 & 29.68 & 29.66 & 29.67 & 29.72 & 29.78 \\ 29.84 & 29.93 & 29.97 & 29.98 & 29.96 & 29.92 & 29.84 & 29.75 \\ 29.66 & 29.56 & 29.46 & 29.37 & 29.30 & 29.25 & 29.23 & 29.24 \\ 29.30 & 29.39 & 29.14 & 29.46 & 29.46 & 29.47 & 29.50 & 29.57 \\ 29.62 & 29.61 & 29.54 & 29.32 & 29.08 & 28.66 & 28.02 & \end{array}$


INST. NO. 79

SBPTEMBER 09, 1975

GD TABLB

\begin{tabular}{|c|c|c|c|c|c|c|c|c|c|c|}
\hline $\mathbf{R}$ & 0 & 1 & 2 & 3 & 4 & 5 & 6 & 7 & 8 & 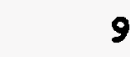 \\
\hline $\begin{array}{r}0 \\
10 \\
20 \\
30 \\
40\end{array}$ & $\begin{array}{r}5.6 \\
17.2 \\
28.2 \\
38.9\end{array}$ & $\begin{array}{r}6.8 \\
18.4 \\
29.3 \\
39.9\end{array}$ & $\begin{array}{r}8.0 \\
19.5 \\
30.4 \\
41.0\end{array}$ & $\begin{array}{r}9.1 \\
20.6 \\
31.4 \\
42.1\end{array}$ & $\begin{array}{l}10.3 \\
21.7 \\
32.5 \\
43.1\end{array}$ & $\begin{array}{l}.0 \\
11.5 \\
22.8 \\
33.6 \\
44.1\end{array}$ & $\begin{array}{r}1.1 \\
12.6 \\
23.9 \\
34.7 \\
45.1\end{array}$ & $\begin{array}{r}2.3 \\
13.8 \\
25.0 \\
35.7 \\
46.1\end{array}$ & $\begin{array}{r}3.4 \\
14.9 \\
26.1 \\
36.8 \\
47.1\end{array}$ & $\begin{array}{r}4.5 \\
16.1 \\
27.1 \\
37.8 \\
48.1\end{array}$ \\
\hline $\begin{array}{l}50 \\
60 \\
70 \\
80 \\
90\end{array}$ & $\begin{array}{l}49.1 \\
58.6 \\
68.1 \\
77.7 \\
87.5\end{array}$ & $\begin{array}{l}50.0 \\
59.5 \\
69.0 \\
78.6 \\
88.5\end{array}$ & $\begin{array}{l}51.0 \\
60.5 \\
70.0 \\
79.6 \\
89.5\end{array}$ & $\begin{array}{l}52.0 \\
61.4 \\
70.9 \\
80.6 \\
90.5\end{array}$ & $\begin{array}{l}52.9 \\
62.4 \\
71.9 \\
81.6 \\
91.5\end{array}$ & $\begin{array}{l}53.9 \\
63.3 \\
72.9 \\
82.6 \\
92.5\end{array}$ & $\begin{array}{l}54.8 \\
64.3 \\
73.8 \\
83.6 \\
93.5\end{array}$ & $\begin{array}{l}55.8 \\
65.2 \\
74.8 \\
84.5 \\
94.5\end{array}$ & $\begin{array}{l}56.7 \\
66.2 \\
75.8 \\
85.5 \\
95.5\end{array}$ & $\begin{array}{l}57.6 \\
67.1 \\
76.7 \\
86.5 \\
96.5\end{array}$ \\
\hline $\begin{array}{l}100 \\
110 \\
120 \\
130 \\
140\end{array}$ & $\begin{array}{r}97.5 \\
107.5 \\
117.6 \\
127.6 \\
137.5\end{array}$ & $\begin{array}{r}98.5 \\
108.5 \\
118.6 \\
128.6 \\
138.5\end{array}$ & $\begin{array}{r}99.5 \\
109.6 \\
129.6 \\
129.6 \\
139.5\end{array}$ & $\begin{array}{l}100.5 \\
110.6 \\
120.6 \\
130.6 \\
140.5\end{array}$ & $\begin{array}{l}101.5 \\
111.6 \\
121.6 \\
131.6 \\
141.5\end{array}$ & $\begin{array}{l}102.5 \\
112.6 \\
122.6 \\
132.6 \\
142.5\end{array}$ & $\begin{array}{l}103.5 \\
113.6 \\
123.6 \\
133.6 \\
243.5\end{array}$ & $\begin{array}{l}104.5 \\
114.6 \\
124.6 \\
134.6 \\
144.5\end{array}$ & $\begin{array}{l}105.5 \\
115.6 \\
125.6 \\
135.6 \\
145.5\end{array}$ & $\begin{array}{l}106.5 \\
116.6 \\
126.6 \\
136.5 \\
146.5\end{array}$ \\
\hline $\begin{array}{l}150 \\
160 \\
170 \\
180 \\
190\end{array}$ & $\begin{array}{l}147.5 \\
157.4 \\
167.4 \\
177.5 \\
187.5\end{array}$ & $\begin{array}{l}148.5 \\
158.4 \\
168.4 \\
178.5 \\
188.6\end{array}$ & $\begin{array}{l}149.5 \\
159.4 \\
169.4 \\
179.5 \\
189.6\end{array}$ & $\begin{array}{l}150.5 \\
160.4 \\
170.4 \\
180.5 \\
190.6\end{array}$ & $\begin{array}{l}151.5 \\
161.4 \\
171.4 \\
181.5 \\
191.6\end{array}$ & $\begin{array}{l}152.5 \\
162.4 \\
172.4 \\
182.5 \\
192.6\end{array}$ & $\begin{array}{l}153.5 \\
163.4 \\
173.4 \\
183.5 \\
193.6\end{array}$ & $\begin{array}{l}154.5 \\
164.4 \\
174.4 \\
184.5 \\
194.6\end{array}$ & $\begin{array}{l}155.5 \\
165.4 \\
175.4 \\
185.5 \\
195.6\end{array}$ & $\begin{array}{l}156.4 \\
166.4 \\
176.4 \\
186.5 \\
196.6\end{array}$ \\
\hline $\begin{array}{l}200 \\
210 \\
220 \\
230 \\
240\end{array}$ & $\begin{array}{l}197.6 \\
207.9 \\
218.0 \\
228.1 \\
238.2\end{array}$ & $\begin{array}{l}198.7 \\
208.9 \\
219.0 \\
229.1 \\
239.2\end{array}$ & $\begin{array}{l}199.7 \\
209.9 \\
220.0 \\
230.1 \\
240.2\end{array}$ & $\begin{array}{l}200.7 \\
210.9 \\
221.1 \\
231.1 \\
241.2\end{array}$ & $\begin{array}{l}201.7 \\
211.9 \\
222.1 \\
232.1 \\
242.2\end{array}$ & $\begin{array}{l}202.7 \\
213.0 \\
223.1 \\
233.1 \\
243.2\end{array}$ & $\begin{array}{l}203.8 \\
214.0 \\
224.1 \\
234.1 \\
244.2\end{array}$ & $\begin{array}{l}204.8 \\
215.0 \\
225.1 \\
235.1 \\
245.2\end{array}$ & $\begin{array}{l}205.8 \\
216.0 \\
226.1 \\
236.1 \\
246.2\end{array}$ & $\begin{array}{l}206.8 \\
217.0 \\
227.1 \\
237.2 \\
247.2\end{array}$ \\
\hline $\begin{array}{l}250 \\
260 \\
270 \\
280 \\
290\end{array}$ & $\begin{array}{l}248.2 \\
258.2 \\
268.3 \\
278.4 \\
289.0\end{array}$ & $\begin{array}{l}249.2 \\
259.2 \\
269.3 \\
279.5 \\
290.1\end{array}$ & $\begin{array}{l}250.2 \\
260.2 \\
270.3 \\
280.5 \\
291.3\end{array}$ & $\begin{array}{l}251.2 \\
261.2 \\
271.3 \\
281.5 \\
292.4\end{array}$ & $\begin{array}{l}252.2 \\
262.2 \\
272.3 \\
282.6 \\
293.5\end{array}$ & $\begin{array}{l}253.2 \\
263.2 \\
273.3 \\
283.6 \\
294.6\end{array}$ & $\begin{array}{l}254.2 \\
264.2 \\
274.3 \\
284.7\end{array}$ & $\begin{array}{l}255.2 \\
265.2 \\
275.4 \\
285.8\end{array}$ & $\begin{array}{l}256.2 \\
266.2 \\
276.4 \\
286.9\end{array}$ & $\begin{array}{l}257.2 \\
267.3 \\
277.4 \\
287.9\end{array}$ \\
\hline
\end{tabular}

INPOT DATA:

$\begin{array}{llllllll}26.97 & 26.75 & 26.98 & 27.52 & 28.21 & 28.98 & 29.73 & 30.42 \\ 31.03 & 31.42 & 31.60 & 31.43 & 31.16 & 30.90 & 30.66 & 30.43 \\ 30.23 & 30.08 & 30.00 & 29.98 & 30.01 & 30.05 & 30.11 & 30.16 \\ 30.22 & 30.25 & 30.27 & 30.29 & 30.27 & 30.22 & 30.17 & 30.08 \\ 30.00 & 29.92 & 29.84 & 29.76 & 29.70 & 29.64 & 29.62 & 29.62 \\ 29.65 & 29.73 & 29.81 & 29.86 & 29.91 & 29.95 & 29.97 & 29.99 \\ 30.02 & 30.01 & 29.92 & 29.72 & 29.38 & 28.88 & 28.22 & \end{array}$




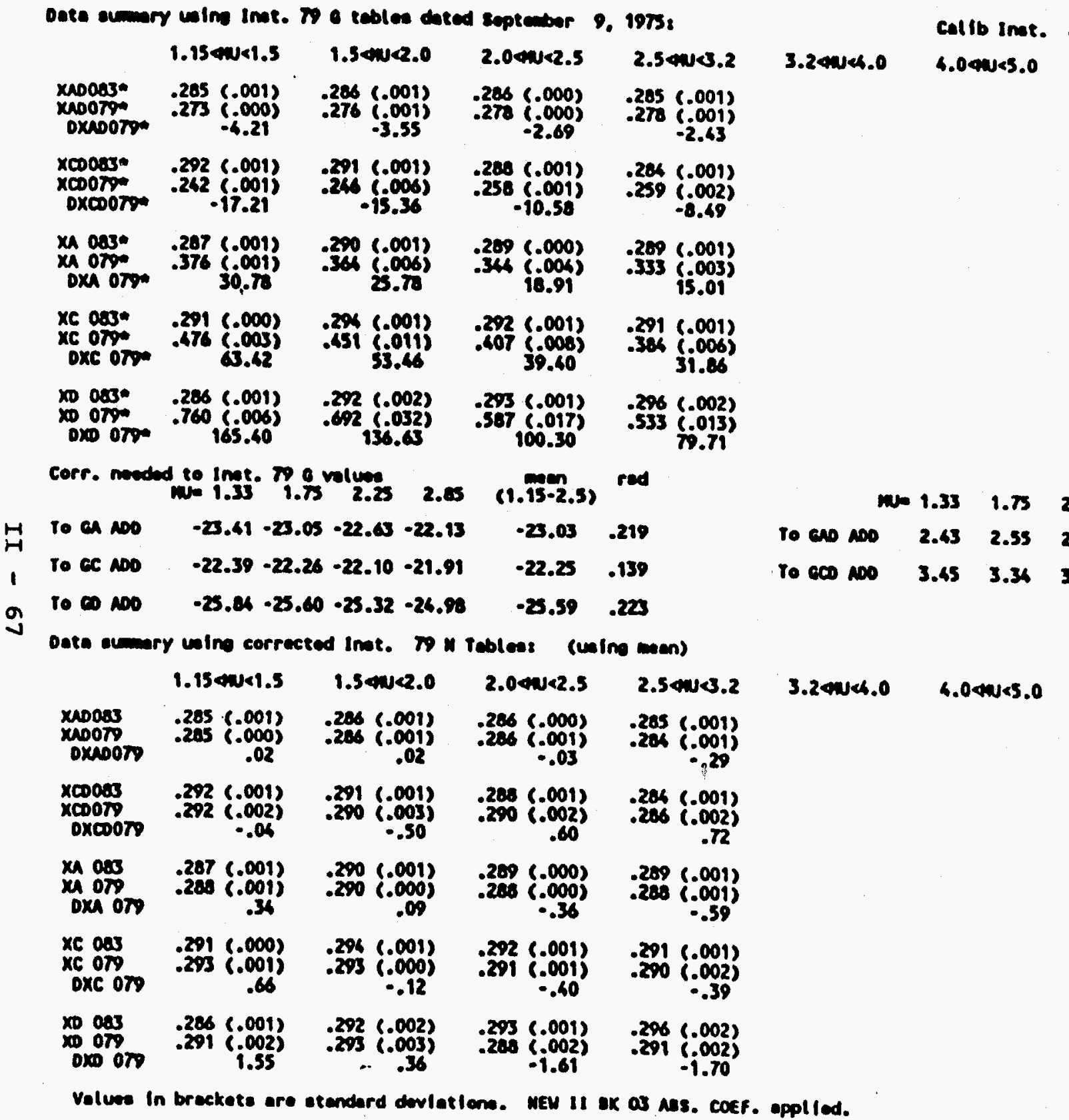

$1.15 \times 403.2$

.285 (.001) Armo-con $(.001)$ ATro-on
. .07 PERCENT

.209 (.003) Armo-or .209 (.002) ATHO-OH .19 PERCENT

.289 (.001) Armo-on $.200(.001)$ ATmo-ca

.292 (.001) ATmo-Ca .202 (.001) ATHO-ca -.06 percent

.292 (.006) ATro36 ATRCEH 

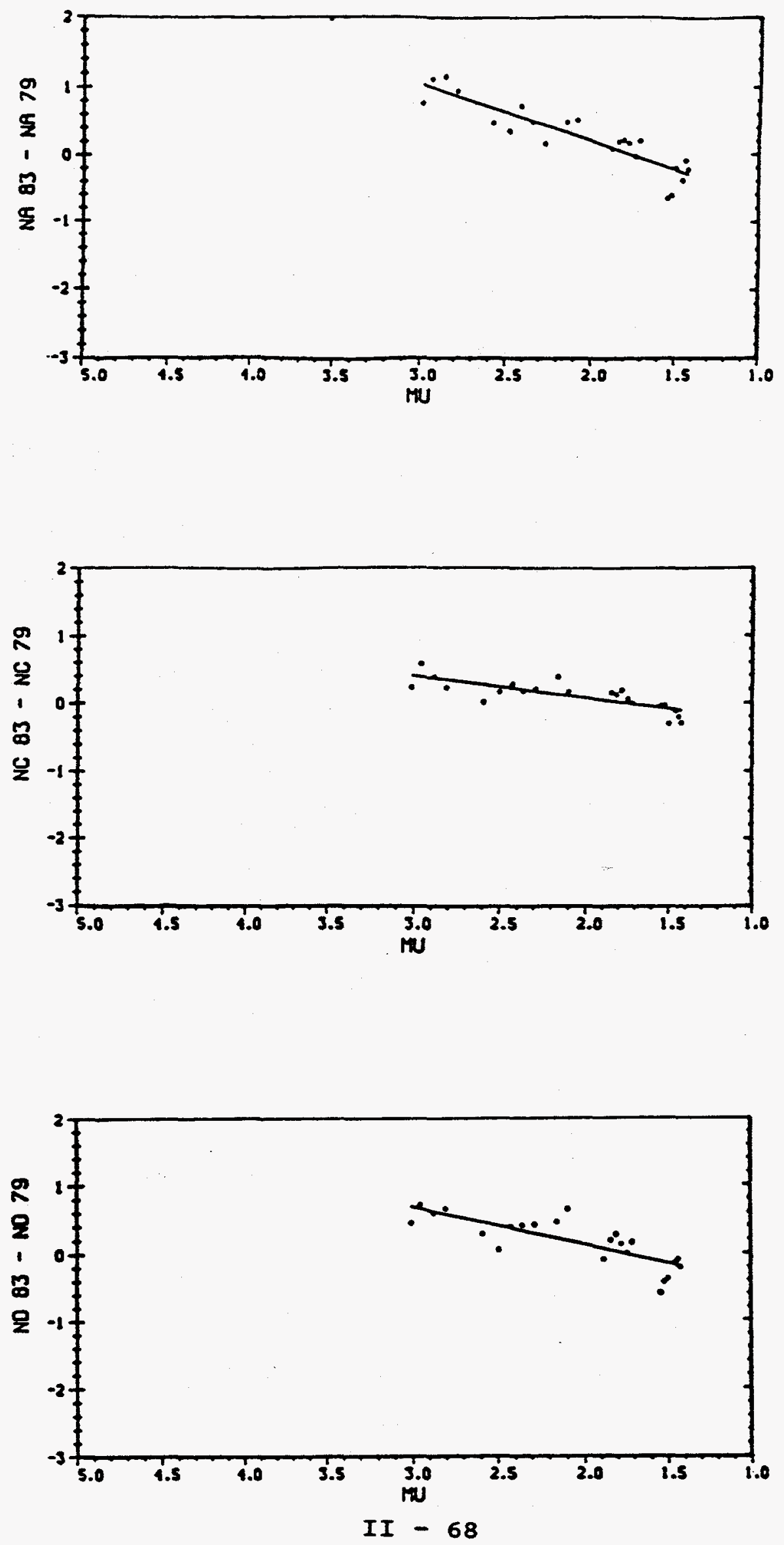
FROM:

N-TABLB

G-TABLB

SRP 9, 1975

INST. 79

SBP 10, 1975

VBRSION: RI

NA TABLB

\begin{tabular}{|c|c|c|c|c|c|c|c|c|c|c|}
\hline $\boldsymbol{R}$ & 0 & 1 & 2 & 3 & 4 & 5 & 6 & 7 & 8 & 9 \\
\hline $\begin{array}{l}0 \\
10 \\
20 \\
30 \\
40\end{array}$ & $\begin{array}{r}-28.7 \\
-17.3 \\
-5.4 \\
6.3 \\
17.1\end{array}$ & $\begin{array}{r}-27.6 \\
-16.2 \\
-4.2 \\
7.5 \\
18.2\end{array}$ & $\begin{array}{r}-26.4 \\
-15.0 \\
-3.0 \\
8.5 \\
19.2\end{array}$ & $\begin{array}{r}-25.3 \\
-13.8 \\
-1.8 \\
9.6 \\
20.2\end{array}$ & $\begin{array}{r}-24.2 \\
-12.6 \\
-.5 \\
10.7 \\
21.3\end{array}$ & $\begin{array}{r}-23.0 \\
-11.5 \\
.7 \\
11.8 \\
22.3\end{array}$ & $\begin{array}{r}-21.9 \\
-10.3 \\
1.8 \\
12.9 \\
23.3\end{array}$ & $\begin{array}{r}-20.8 \\
-9.0 \\
3.0 \\
14.0 \\
24.3\end{array}$ & $\begin{array}{r}-19.6 \\
-7.8 \\
4.1 \\
15.0 \\
25.3\end{array}$ & $\begin{array}{r}-18.5 \\
-6.6 \\
5.2 \\
16.1 \\
26.3\end{array}$ \\
\hline $\begin{array}{l}50 \\
60 \\
70 \\
80 \\
90\end{array}$ & $\begin{array}{l}27.3 \\
36.7 \\
45.9 \\
55.3 \\
65.2\end{array}$ & $\begin{array}{l}28.3 \\
37.7 \\
46.8 \\
56.3 \\
66.2\end{array}$ & $\begin{array}{l}29.3 \\
38.6 \\
47.8 \\
57.2 \\
67.2\end{array}$ & $\begin{array}{l}30.2 \\
39.5 \\
48.7 \\
58.2 \\
68.2\end{array}$ & $\begin{array}{l}31.2 \\
40.4 \\
49.6 \\
59.2 \\
69.2\end{array}$ & $\begin{array}{l}32.2 \\
41.3 \\
50.6 \\
60.2 \\
70.2\end{array}$ & $\begin{array}{l}33.1 \\
42.2 \\
51.5 \\
61.1 \\
71.2\end{array}$ & $\begin{array}{l}34.0 \\
43.1 \\
52.5 \\
62.1 \\
72.2\end{array}$ & $\begin{array}{l}34.9 \\
44.0 \\
53.4 \\
63.1 \\
73.2\end{array}$ & \\
\hline $\begin{array}{l}00 \\
10 \\
20 \\
30 \\
40\end{array}$ & $\begin{array}{r}75.3 \\
85.4 \\
95.7 \\
106.0 \\
116.2\end{array}$ & $\begin{array}{r}76.3 \\
86.5 \\
96.7 \\
107.0 \\
117.2\end{array}$ & $\begin{array}{r}77.3 \\
87.5 \\
97.8 \\
108.0 \\
118.2\end{array}$ & $\begin{array}{r}78.3 \\
88.5 \\
98.8 \\
109.1 \\
119.2\end{array}$ & $\begin{array}{r}79.3 \\
89.5 \\
99.8 \\
110.1 \\
120.2\end{array}$ & $\begin{array}{r}80.4 \\
90.5 \\
100.9 \\
111.1 \\
121.2\end{array}$ & $\begin{array}{r}81.4 \\
91.6 \\
101.9 \\
112.1 \\
122.2\end{array}$ & $\begin{array}{r}82.4 \\
92.6 \\
102.9 \\
113.1 \\
123.3\end{array}$ & $\begin{array}{r}83.4 \\
93.6 \\
103.9 \\
114.1 \\
124.3\end{array}$ & $\begin{array}{r}84.4 \\
94.7 \\
105.0 \\
115.2 \\
125.3\end{array}$ \\
\hline $\begin{array}{l}150 \\
160 \\
170 \\
180 \\
190\end{array}$ & $\begin{array}{l}126.3 \\
136.5 \\
146.7 \\
156.9 \\
167.3\end{array}$ & $\begin{array}{l}127.3 \\
137.6 \\
147.7 \\
158.0 \\
168.3\end{array}$ & $\begin{array}{l}128.4 \\
138.6 \\
148.7 \\
159.0 \\
169.4\end{array}$ & $\begin{array}{l}129.4 \\
139.6 \\
149.7 \\
160.0 \\
170.4\end{array}$ & $\begin{array}{l}130.4 \\
140.6 \\
150.7 \\
161.1 \\
171.4\end{array}$ & $\begin{array}{l}131.4 \\
141.6 \\
151.7 \\
162.1 \\
172.5\end{array}$ & $\begin{array}{l}132.5 \\
142.6 \\
152.8 \\
163.1 \\
173.5\end{array}$ & $\begin{array}{l}133.5 \\
143.6 \\
153.8 \\
164.2 \\
174.6\end{array}$ & $\begin{array}{l}134.5 \\
144.7 \\
154.9 \\
165.2 \\
175.6\end{array}$ & $\begin{array}{l}135.5 \\
145.7 \\
155.9 \\
166.3 \\
176.6\end{array}$ \\
\hline $\begin{array}{l}200 \\
210 \\
220 \\
230\end{array}$ & $\begin{array}{l}177.7 \\
188.1 \\
198.6 \\
208.9 \\
219.3\end{array}$ & $\begin{array}{l}178.7 \\
189.2 \\
199.6 \\
209.9 \\
220.3\end{array}$ & $\begin{array}{l}179.7 \\
190.2 \\
200.7 \\
211.0 \\
221.4\end{array}$ & $\begin{array}{l}180.8 \\
191.3 \\
201.7 \\
212.0 \\
222.4\end{array}$ & $\begin{array}{l}181.8 \\
192.3 \\
202.7 \\
213.0 \\
223.5\end{array}$ & $\begin{array}{l}182.9 \\
193.4 \\
203.8 \\
214.1 \\
224.5\end{array}$ & $\begin{array}{l}183.9 \\
194.4 \\
204.8 \\
215.1 \\
225.6\end{array}$ & $\begin{array}{l}185.0 \\
195.5 \\
205.8 \\
216.2 \\
226.6\end{array}$ & $\begin{array}{l}186.0 \\
196.5 \\
206.9 \\
217.2 \\
227.7\end{array}$ & $\begin{array}{l}187.1 \\
197.6 \\
207.9 \\
218.2 \\
228.7\end{array}$ \\
\hline $\begin{array}{l}250 \\
260 \\
270 \\
280\end{array}$ & $\begin{array}{l}229.7 \\
240.1 \\
250.4 \\
260.8 \\
271.5\end{array}$ & $\begin{array}{l}230.8 \\
241.1 \\
251.4 \\
261.8 \\
272.6\end{array}$ & $\begin{array}{l}231.8 \\
242.1 \\
252.4 \\
262.9 \\
273.8\end{array}$ & $\begin{array}{l}232.9 \\
243.1 \\
253.4 \\
263.9 \\
274.9\end{array}$ & $\begin{array}{l}233.9 \\
244.2 \\
254.5 \\
265.0 \\
276.0\end{array}$ & $\begin{array}{l}234.9 \\
245.2 \\
255.5 \\
266.1 \\
277.2\end{array}$ & $\begin{array}{l}236.0 \\
246.2 \\
256.6 \\
267.2\end{array}$ & $\begin{array}{l}237.0 \\
247.3 \\
257.6 \\
268.2\end{array}$ & $\begin{array}{l}238.0 \\
248.3 \\
258.7 \\
269.3\end{array}$ & $\begin{array}{l}239.0 \\
249.3 \\
259.7 \\
270.4\end{array}$ \\
\hline
\end{tabular}


NC TABLB

\begin{tabular}{|c|c|c|c|c|c|c|c|c|c|c|}
\hline $\boldsymbol{R}$ & 0 & 1 & 2 & 3 & 4 & 5 & 6 & 7 & 8 & 9 \\
\hline $\begin{array}{l}0 \\
10 \\
20 \\
30 \\
40\end{array}$ & $\begin{array}{r}-27.9 \\
-16.6 \\
-4.7 \\
6.6 \\
17.4\end{array}$ & $\begin{array}{r}-26.8 \\
-15.4 \\
-3.6 \\
7.7 \\
18.5\end{array}$ & $\begin{array}{r}-25.7 \\
-14.2 \\
-2.4 \\
8.8 \\
19.5\end{array}$ & $\begin{array}{r}-24.5 \\
-13.0 \\
-1.3 \\
9.9 \\
20.5\end{array}$ & $\begin{array}{r}-23.4 \\
-11.9 \\
-.1 \\
11.0 \\
21.5\end{array}$ & $\begin{array}{r}-22.3 \\
-10.7 \\
1.0 \\
12.1 \\
22.6\end{array}$ & $\begin{array}{r}-21.1 \\
.9 .5 \\
2.2 \\
13.2 \\
23.6\end{array}$ & $\begin{array}{r}-20.0 \\
-8.3 \\
3.3 \\
14.3 \\
24.6\end{array}$ & $\begin{array}{r}-18.8 \\
-7.1 \\
4.4 \\
15.3 \\
25.6\end{array}$ & $\begin{array}{r}-17.7 \\
-5.9 \\
5.5 \\
16.4 \\
26.6\end{array}$ \\
\hline $\begin{array}{l}50 \\
60 \\
70 \\
80 \\
90\end{array}$ & $\begin{array}{l}27.5 \\
37.0 \\
46.4 \\
55.9 \\
65.7\end{array}$ & $\begin{array}{l}28.5 \\
37.9 \\
47.3 \\
56.8 \\
66.7\end{array}$ & $\begin{array}{l}29.5 \\
38.9 \\
48.2 \\
57.8 \\
67.7\end{array}$ & $\begin{array}{l}30.4 \\
39.8 \\
49.2 \\
58.8 \\
68.7\end{array}$ & $\begin{array}{l}31.4 \\
40.7 \\
50.1 \\
59.7 \\
69.7\end{array}$ & $\begin{array}{l}32.3 \\
41.7 \\
51.1 \\
60.7 \\
70.7\end{array}$ & $\begin{array}{l}33.3 \\
42.6 \\
52.0 \\
61.7 \\
71.7\end{array}$ & $\begin{array}{l}34.2 \\
43.5 \\
53.0 \\
62.7 \\
72.7\end{array}$ & $\begin{array}{l}35.1 \\
44.5 \\
53.9 \\
63.7 \\
73.7\end{array}$ & $\begin{array}{l}36.1 \\
45.4 \\
54.9 \\
64.7 \\
74.7\end{array}$ \\
\hline $\begin{array}{l}100 \\
110 \\
120 \\
130 \\
140\end{array}$ & $\begin{array}{r}75.7 \\
85.8 \\
96.0 \\
106.1 \\
116.2\end{array}$ & $\begin{array}{r}76.7 \\
86.8 \\
97.0 \\
107.1 \\
117.2\end{array}$ & $\begin{array}{r}77.7 \\
87.8 \\
98.0 \\
108.1 \\
118.2\end{array}$ & $\begin{array}{r}78.7 \\
88.8 \\
99.0 \\
109.2 \\
119.2\end{array}$ & $\begin{array}{r}79.7 \\
89.9 \\
100.1 \\
110.2 \\
120.2\end{array}$ & $\begin{array}{r}80.7 \\
90.9 \\
101.1 \\
111.2 \\
121.2\end{array}$ & $\begin{array}{r}81.7 \\
91.9 \\
102.1 \\
112.2 \\
122.2\end{array}$ & $\begin{array}{r}82.8 \\
92.9 \\
103.1 \\
113.2 \\
123.2\end{array}$ & $\begin{array}{r}83.8 \\
93.9 \\
104.1 \\
114.2 \\
124.2\end{array}$ & $\begin{array}{r}84.8 \\
95.0 \\
105.1 \\
115.2 \\
125.2\end{array}$ \\
\hline $\begin{array}{l}150 \\
160 \\
170 \\
180 \\
190\end{array}$ & $\begin{array}{l}126.2 \\
136.3 \\
146.3 \\
156.5 \\
166.7\end{array}$ & $\begin{array}{l}127.3 \\
137.3 \\
147.3 \\
157.5 \\
167.7\end{array}$ & $\begin{array}{l}128.3 \\
138.3 \\
148.3 \\
158.6 \\
168.8\end{array}$ & $\begin{array}{l}129.3 \\
139.3 \\
149.4 \\
159.6 \\
169.8\end{array}$ & $\begin{array}{l}130.3 \\
140.3 \\
150.4 \\
160.6 \\
170.8\end{array}$ & $\begin{array}{l}131.3 \\
141.3 \\
151.4 \\
161.6 \\
171.8\end{array}$ & $\begin{array}{l}132.3 \\
142.3 \\
152.4 \\
162.6 \\
172.9\end{array}$ & $\begin{array}{l}133.3 \\
143.3 \\
153.4 \\
163.7 \\
173.9\end{array}$ & $\begin{array}{l}134.3 \\
144.3 \\
154.5 \\
164.7 \\
174.9\end{array}$ & $\begin{array}{l}135.3 \\
145.3 \\
155.5 \\
165.7 \\
175.9\end{array}$ \\
\hline $\begin{array}{l}200 \\
210 \\
220 \\
230 \\
240\end{array}$ & $\begin{array}{l}177.0 \\
187.3 \\
197.6 \\
207.8 \\
218.0\end{array}$ & $\begin{array}{l}178.0 \\
188.4 \\
198.6 \\
208.8 \\
219.1\end{array}$ & $\begin{array}{l}179.0 \\
189.4 \\
199.6 \\
209.8 \\
220.1\end{array}$ & $\begin{array}{l}180.1 \\
190.4 \\
200.7 \\
210.8 \\
221.1\end{array}$ & $\begin{array}{l}181.1 \\
191.5 \\
201.7 \\
211.9 \\
222.1\end{array}$ & $\begin{array}{l}182.2 \\
192.5 \\
202.7 \\
212.9 \\
223.1\end{array}$ & $\begin{array}{l}183.2 \\
193.5 \\
203.7 \\
213.9 \\
224.2\end{array}$ & $\begin{array}{l}184.2 \\
194.5 \\
204.7 \\
214.9 \\
225.2\end{array}$ & $\begin{array}{l}185.3 \\
195.6 \\
205.8 \\
216.0 \\
226.2\end{array}$ & $\begin{array}{l}186.3 \\
196.6 \\
206.8 \\
217.0 \\
227.2\end{array}$ \\
\hline $\begin{array}{l}250 \\
260 \\
270 \\
280\end{array}$ & $\begin{array}{l}228.3 \\
238.4 \\
248.5 \\
258.9 \\
269.5\end{array}$ & $\begin{array}{l}229.3 \\
239.4 \\
249.6 \\
259.9 \\
270.6\end{array}$ & $\begin{array}{l}230.3 \\
240.4 \\
250.6 \\
261.0 \\
271.7\end{array}$ & $\begin{array}{l}231.3 \\
241.4 \\
251.6 \\
262.0 \\
272.8\end{array}$ & $\begin{array}{l}232.3 \\
242.4 \\
252.6 \\
263.1\end{array}$ & $\begin{array}{l}233.3 \\
243.4 \\
253.7 \\
264.2\end{array}$ & $\begin{array}{l}234.4 \\
244.4 \\
254.7 \\
265.2\end{array}$ & $\begin{array}{l}235.4 \\
245.5 \\
255.7 \\
266.3\end{array}$ & $\begin{array}{l}236.4 \\
246.5 \\
256.8 \\
267.3\end{array}$ & $\begin{array}{l}237.4 \\
247.5 \\
257.8 \\
268.4\end{array}$ \\
\hline
\end{tabular}


FROM:

G-TABLB

SBP 9, 1975

$N$ - TABLB

INST. 79

SBP 10, 1975

VBRSION: RI

ND TABLB

\begin{tabular}{|c|c|c|c|c|c|c|c|c|c|c|}
\hline $\boldsymbol{R}$ & 0 & 1 & 2 & 3 & 4 & 5 & 6 & 7 & 8 & 9 \\
\hline $\begin{array}{r}0 \\
10 \\
20 \\
30 \\
40\end{array}$ & $\begin{array}{r}-31.2 \\
-20.0 \\
-8.4 \\
2.6 \\
13.3\end{array}$ & $\begin{array}{r}-30.1 \\
-18.8 \\
-7.2 \\
3.7 \\
14.4\end{array}$ & $\begin{array}{r}-29.0 \\
-17.6 \\
-6.1 \\
4.8 \\
15.4\end{array}$ & $\begin{array}{r}-27.8 \\
-16.5 \\
-5.0 \\
5.9 \\
16.5\end{array}$ & $\begin{array}{r}-26.7 \\
-15.3 \\
-3.9 \\
6.9 \\
17.5\end{array}$ & $\begin{array}{r}-25.6 \\
-14.1 \\
-2.8 \\
8.0 \\
18.5\end{array}$ & $\begin{array}{r}-24.5 \\
-13.0 \\
-1.7 \\
9.1 \\
19.5\end{array}$ & $\begin{array}{r}-23.3 \\
-11.8 \\
-.6 \\
10.1 \\
20.5\end{array}$ & $\begin{array}{r}-22.2 \\
-10.7 \\
.5 \\
11.2 \\
21.5\end{array}$ & $\begin{array}{r}-21.1 \\
-9.5 \\
1.5 \\
12.3 \\
22.5\end{array}$ \\
\hline $\begin{array}{l}50 \\
60 \\
70 \\
80 \\
90\end{array}$ & $\begin{array}{l}23.5 \\
33.0 \\
42.5 \\
52.1 \\
61.9\end{array}$ & $\begin{array}{l}24.5 \\
33.9 \\
43.4 \\
53.0 \\
62.9\end{array}$ & $\begin{array}{l}25.4 \\
34.9 \\
44.4 \\
54.0 \\
63.9\end{array}$ & $\begin{array}{l}26.4 \\
35.8 \\
45.4 \\
55.0 \\
64.9\end{array}$ & $\begin{array}{l}27.3 \\
36.8 \\
46.3 \\
56.0 \\
65.9\end{array}$ & $\begin{array}{l}28.3 \\
37.7 \\
47.3 \\
57.0 \\
66.9\end{array}$ & $\begin{array}{l}29.2 \\
38.7 \\
48.2 \\
58.0 \\
67.9\end{array}$ & $\begin{array}{l}30.2 \\
39.6 \\
49.2 \\
58.9 \\
68.9\end{array}$ & $\begin{array}{l}31.1 \\
40.6 \\
50.2 \\
59.9 \\
69.9\end{array}$ & $\begin{array}{l}32.1 \\
41.5 \\
51.1 \\
60.9 \\
70.9\end{array}$ \\
\hline $\begin{array}{l}100 \\
110 \\
120 \\
130 \\
140\end{array}$ & $\begin{array}{r}71.9 \\
82.0 \\
92.0 \\
102.0 \\
112.0\end{array}$ & $\begin{array}{r}72.9 \\
83.0 \\
93.0 \\
103.0 \\
112.9\end{array}$ & $\begin{array}{r}73.9 \\
84.0 \\
94.0 \\
104.0 \\
113.9\end{array}$ & $\begin{array}{r}74.9 \\
85.0 \\
95.0 \\
105.0 \\
114.9\end{array}$ & $\begin{array}{r}75.9 \\
86.0 \\
96.0 \\
106.0 \\
115.9\end{array}$ & $\begin{array}{r}76.9 \\
87.0 \\
97.0 \\
107.0 \\
116.9\end{array}$ & $\begin{array}{r}77.9 \\
88.0 \\
98.0 \\
108.0 \\
117.9\end{array}$ & $\begin{array}{r}78.9 \\
89.0 \\
99.0 \\
109.0 \\
118.9\end{array}$ & $\begin{array}{r}79.9 \\
90.0 \\
100.0 \\
110.0 \\
119.9\end{array}$ & $\begin{array}{r}81.0 \\
91.0 \\
101.0 \\
111.0 \\
120.9\end{array}$ \\
\hline $\begin{array}{l}150 \\
160 \\
170 \\
180 \\
190\end{array}$ & $\begin{array}{l}121.9 \\
131.8 \\
141.8 \\
151.9 \\
162.0\end{array}$ & $\begin{array}{l}122.9 \\
132.8 \\
142.8 \\
152.9 \\
163.0\end{array}$ & $\begin{array}{l}123.9 \\
133.8 \\
143.8 \\
153.9 \\
164.0\end{array}$ & $\begin{array}{l}124.9 \\
134.8 \\
144.8 \\
154.9 \\
165.0\end{array}$ & $\begin{array}{l}125.9 \\
135.8 \\
145.8 \\
155.9 \\
166.0\end{array}$ & $\begin{array}{l}126.9 \\
136.8 \\
146.8 \\
156.9 \\
167.0\end{array}$ & $\begin{array}{l}127.9 \\
137.8 \\
147.8 \\
157.9 \\
168.0\end{array}$ & $\begin{array}{l}128.9 \\
138.8 \\
148.8 \\
158.9 \\
169.0\end{array}$ & $\begin{array}{l}129.9 \\
139.8 \\
149.8 \\
159.9 \\
170.0\end{array}$ & $\begin{array}{l}130.9 \\
140.8 \\
150.8 \\
160.9 \\
171.0\end{array}$ \\
\hline $\begin{array}{l}200 \\
210 \\
220 \\
230 \\
240\end{array}$ & $\begin{array}{l}172 \cdot 1 \\
182.3 \\
192.4 \\
202.5 \\
212.6\end{array}$ & $\begin{array}{l}173.1 \\
183.3 \\
193.4 \\
203.5 \\
213.6\end{array}$ & $\begin{array}{l}174.1 \\
184.3 \\
194.5 \\
204.5 \\
214.6\end{array}$ & $\begin{array}{l}175.1 \\
185.3 \\
195.5 \\
205.5 \\
215.6\end{array}$ & $\begin{array}{l}176 \cdot 1 \\
186.3 \\
196 \cdot 5 \\
206.5 \\
216.6\end{array}$ & $\begin{array}{l}177.2 \\
187.4 \\
197.5 \\
207.5 \\
217.6\end{array}$ & $\begin{array}{l}178.2 \\
188.4 \\
198.5 \\
208.5 \\
218.6\end{array}$ & $\begin{array}{l}179.2 \\
189.4 \\
199.5 \\
209.6 \\
219.6\end{array}$ & $\begin{array}{l}180.2 \\
190.4 \\
200.5 \\
210.6 \\
220.6\end{array}$ & $\begin{array}{l}181.2 \\
191.4 \\
201.5 \\
211.6 \\
221.6\end{array}$ \\
\hline $\begin{array}{l}250 \\
260 \\
270 \\
280 \\
200\end{array}$ & $\begin{array}{l}222.6 \\
232.6 \\
242.7 \\
252.8 \\
263.4\end{array}$ & $\begin{array}{l}223.6 \\
233.6 \\
243.7 \\
253.9 \\
264.5\end{array}$ & $\begin{array}{l}224.6 \\
234.6 \\
244.7 \\
254.9 \\
265.7\end{array}$ & $\begin{array}{l}225.6 \\
235.6 \\
245.7 \\
256.0 \\
266.8\end{array}$ & $\begin{array}{l}226.6 \\
236.6 \\
246.7 \\
257.0 \\
267.9\end{array}$ & $\begin{array}{l}227.6 \\
237.6 \\
247.7 \\
258.1 \\
269.1\end{array}$ & $\begin{array}{l}228.6 \\
238.6 \\
248.7 \\
259.1\end{array}$ & $\begin{array}{l}229.6 \\
239.6 \\
249.8 \\
260.2\end{array}$ & $\begin{array}{l}230.6 \\
240.6 \\
250.8 \\
261.3\end{array}$ & $\begin{array}{l}231.6 \\
241.7 \\
251.8 \\
262.4\end{array}$ \\
\hline
\end{tabular}

II -71 
INST. NO,

79

DATE,

Sept. 10, 1975

REEERENCE STANDARD LAMP DATA

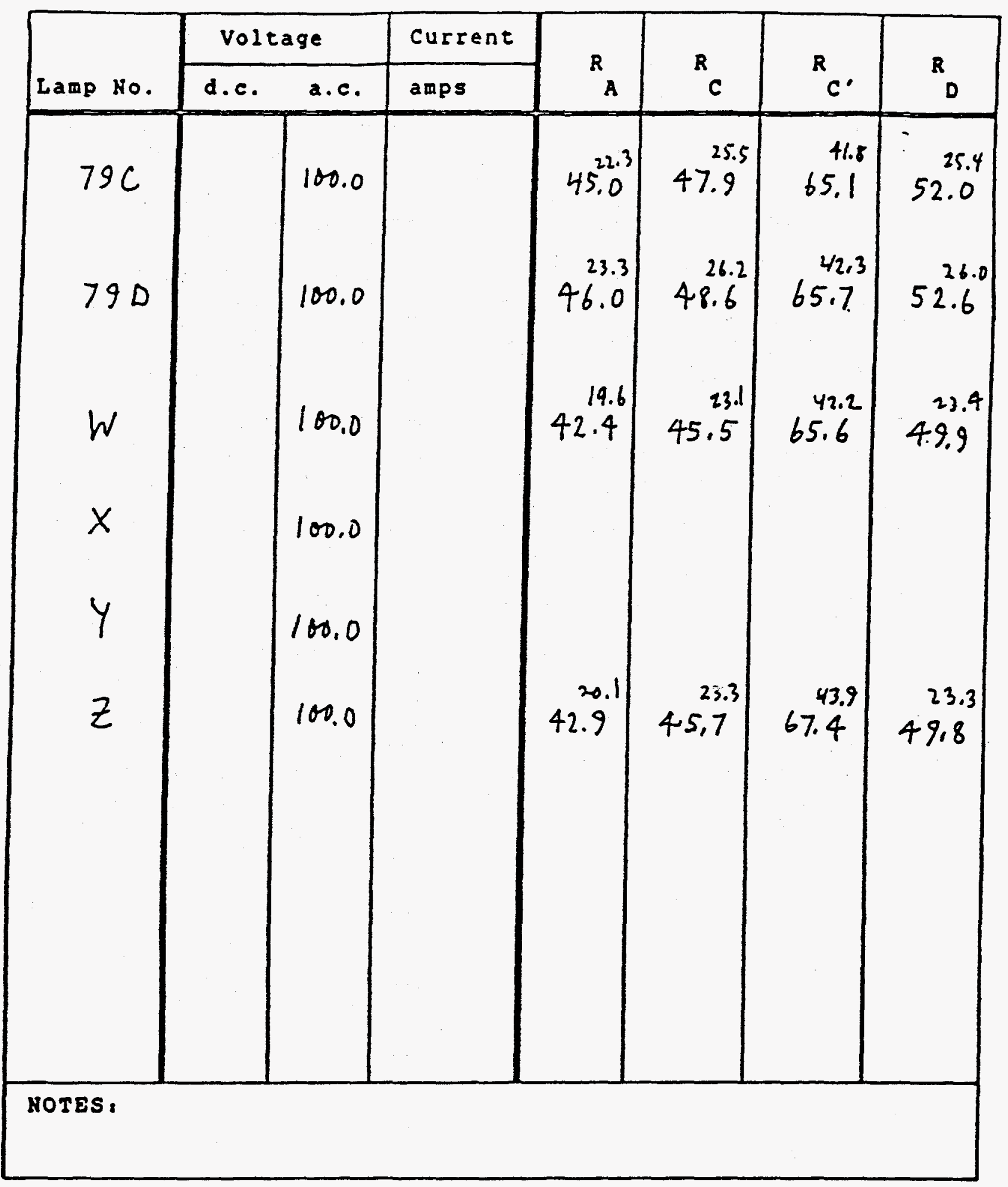

II -72 


\section{DOBSON OZONE SPECTROPHOTOMETER CALIBRATION}

$$
\text { Place: Boulder Colorado }
$$

Oole: $\frac{\text { Quy. 14, 1981 }}{\text { U.S.A. inst. No. }} 79$ vs $\frac{\text { A.M./F.M. U.S.A. A.M. Inst. No. } 65}{\text { (Country) }}$

for instrument No. 79 use $N$ tables dated Sept. 10, 1975 RI

Apply the following corrections to the tables:

To $G$ or $M A$ values asd $\frac{-6.8}{-6.6}$
To $G C$ or NC values add $\frac{-5.5}{\text { To } G 0 \text { or ND values add }}$

For instrument No. 65 use $N$ tables dated april $10,198|\mathrm{~F}|$ Apply the following corrections to the tables:

To GA or MA values ood

To GC or NC values add

$\frac{-0.1}{-0.2}$

TO GO or ND values add Nores: "Final" calihation, with instrument just with secondary standard instrument 65 . 


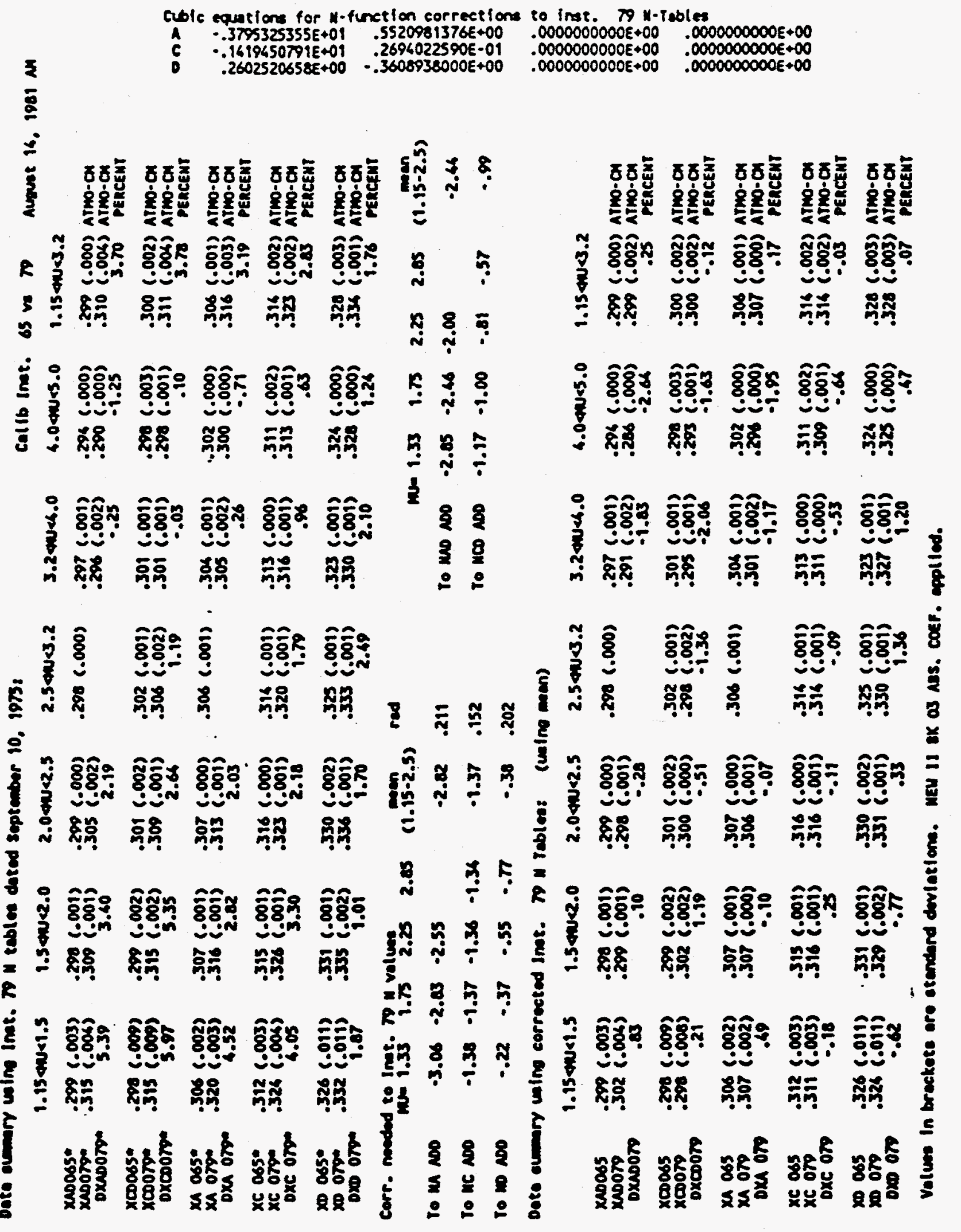



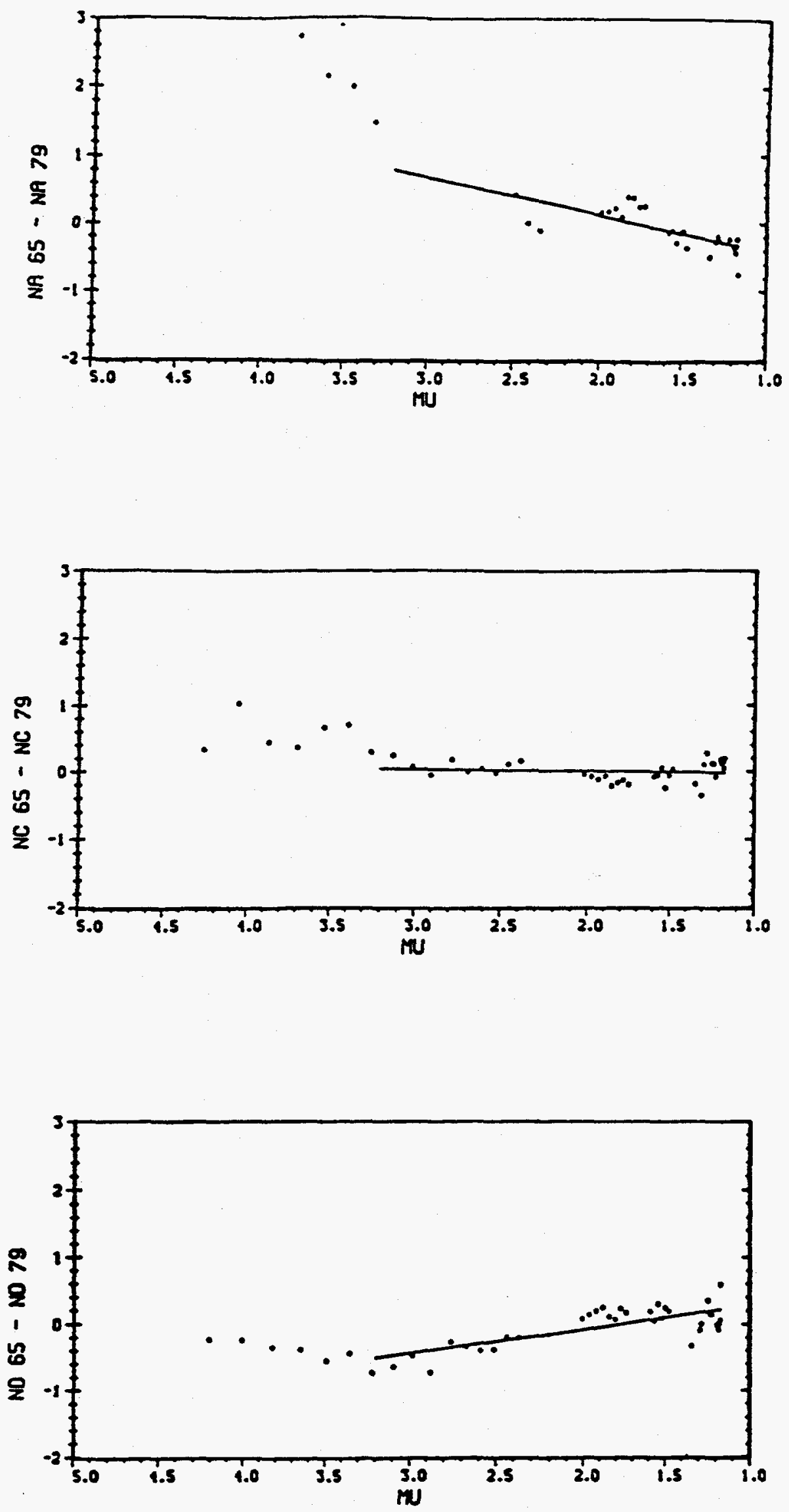

$I I-75$ 
DOBSON OZONE SPECTROPHOTOMETER CALIBRATION

Place: Boulder, Colorado

Dale: Aug mst 14,1981

A.M./F.M.

A.M. U.S.A._ inst. Ho. 79 vs U.S.A. Inst. No. 65 (Country)

(Country)

For instrument No. 79 use $G$ tables dated Aug. 24,1981 Apply the following corrections to the tables:

To GA or NA values add

$-29.2$

To GC or MC values add

$-28.3$

To 60 or NO values add

$-30.4$

For instrument No. 65 use $N$ tables dated April 10,1981 Fl Apply the following corrections to the tables:

To GA or MA values add

To $6 C$ or NC values add

To 60 or NO values add
$-0.1$

$-0.2$

$-0.2$

notes: "Find" calibration, using new (Aug. 24, 1981) optical wedge density data.

* There $\Delta G$ values convert the $G$-tables to NoTables based on reference standard lamp $N$ values determined September 10,1975 (see next page)

II -76 
DG-Value Computations

Standard lamep readings: Angust 14, 1981

Reference standard lamp N-values: September 10, 1975 RI

Lamp

$$
\underline{R_{A}} \underline{R_{C}} \underline{R_{D}}
$$

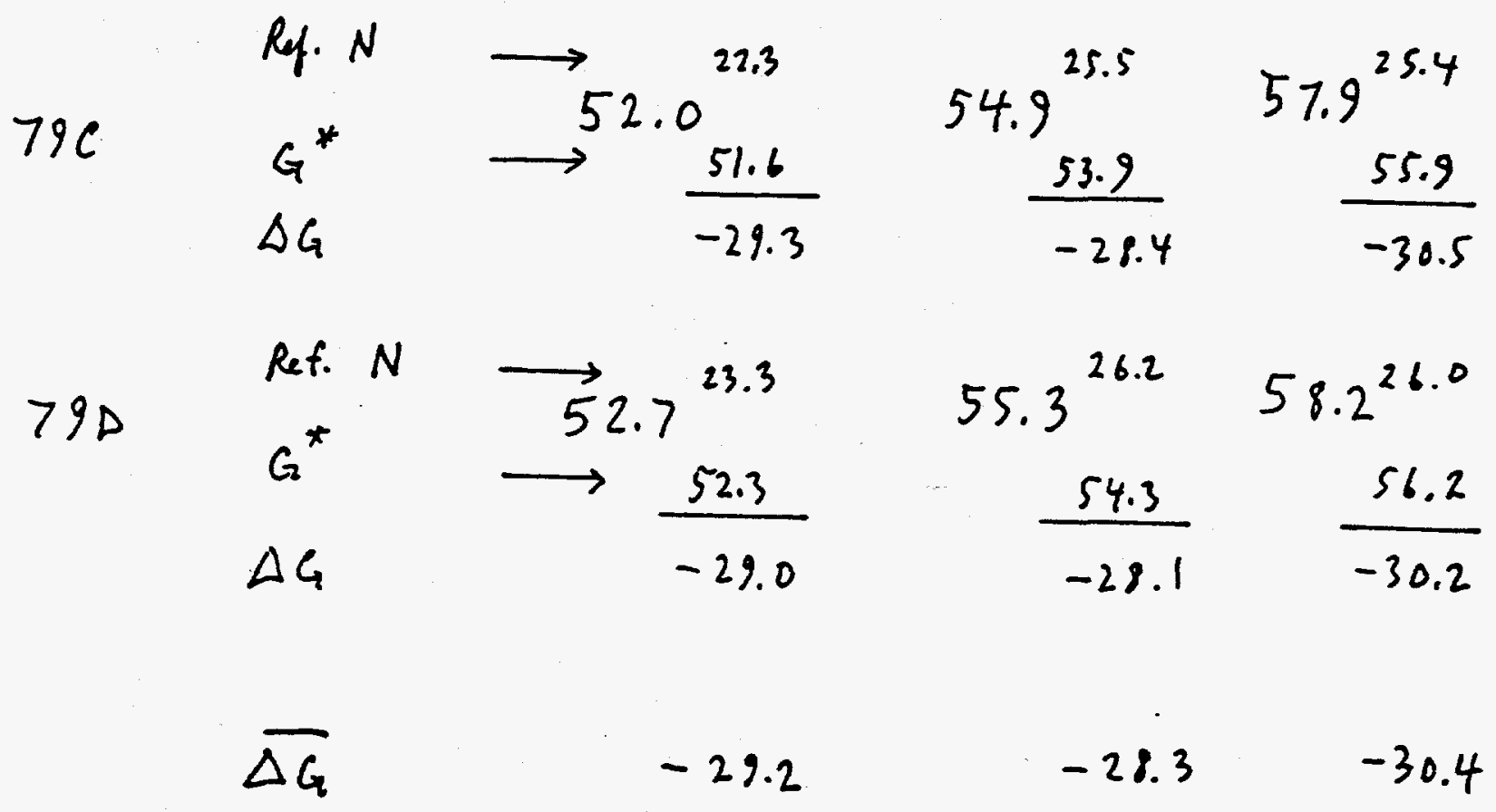

* From G tables dated ang. 24, 1981 $\Delta G=N_{A S}-G_{A S}$

II -77 
GA TABLB

\begin{tabular}{|c|c|c|c|c|c|c|c|c|c|c|}
\hline $\mathbf{R}$ & 0 & 1 & 2 & 3 & 4 & 5 & 6 & 7 & 8 & 9 \\
\hline $\begin{array}{l}0 \\
10 \\
20 \\
30 \\
40\end{array}$ & $\begin{array}{r}5.9 \\
17.5 \\
29.3 \\
40.1\end{array}$ & $\begin{array}{r}7.1 \\
18.7 \\
30.4 \\
41.1\end{array}$ & $\begin{array}{r}8.2 \\
19.9 \\
31.5 \\
42.1\end{array}$ & $\begin{array}{r}9.3 \\
21.1 \\
32.7 \\
43.1\end{array}$ & $\begin{array}{l}10.5 \\
22.3 \\
33.8 \\
44.0\end{array}$ & $\begin{array}{r}.0 \\
11.6 \\
23.5 \\
34.9 \\
45.0\end{array}$ & $\begin{array}{r}1.2 \\
12.8 \\
24.6 \\
36.0 \\
46.0\end{array}$ & $\begin{array}{r}2.4 \\
13.9 \\
25.8 \\
37.1 \\
46.9\end{array}$ & $\begin{array}{r}3.6 \\
15.1 \\
27.0 \\
38.1 \\
47.9\end{array}$ & $\begin{array}{r}4.7 \\
16.3 \\
28.1 \\
39.1 \\
48.8\end{array}$ \\
\hline $\begin{array}{l}50 \\
60 \\
70 \\
80 \\
90\end{array}$ & $\begin{array}{l}49.8 \\
59.0 \\
68.1 \\
77.2 \\
86.7\end{array}$ & $\begin{array}{l}50.7 \\
60.0 \\
69.1 \\
78.2 \\
87.7\end{array}$ & $\begin{array}{l}51.6 \\
60.9 \\
70.0 \\
79.1 \\
88.6\end{array}$ & $\begin{array}{l}52.6 \\
61.8 \\
70.9 \\
80.0 \\
89.6\end{array}$ & $\begin{array}{l}53.5 \\
62.7 \\
71.8 \\
81.0 \\
90.6\end{array}$ & $\begin{array}{l}54.5 \\
63.6 \\
72.7 \\
81.9 \\
91.6\end{array}$ & $\begin{array}{l}55.4 \\
64.5 \\
73.6 \\
82.9 \\
92.6\end{array}$ & $\begin{array}{l}56.3 \\
65.4 \\
74.5 \\
83.8 \\
93.6\end{array}$ & $\begin{array}{l}57.2 \\
66.3 \\
75.4 \\
84.7 \\
94.5\end{array}$ & $\begin{array}{l}58.1 \\
67.2 \\
76.3 \\
85.7 \\
95.5\end{array}$ \\
\hline $\begin{array}{l}100 \\
110 \\
120 \\
130 \\
140\end{array}$ & $\begin{array}{r}96.5 \\
106.7 \\
116.8 \\
127.0 \\
137.2\end{array}$ & $\begin{array}{r}97.5 \\
107.7 \\
117.8 \\
128.0 \\
138.2\end{array}$ & $\begin{array}{r}98.6 \\
108.7 \\
118.8 \\
129.0 \\
139.2\end{array}$ & $\begin{array}{r}99.6 \\
109.7 \\
119.8 \\
130.0 \\
140.2\end{array}$ & $\begin{array}{l}100.6 \\
110.7 \\
120.8 \\
131.1 \\
141.3\end{array}$ & $\begin{array}{l}101.6 \\
111.7 \\
121.8 \\
132.1 \\
142.3\end{array}$ & $\begin{array}{l}102.6 \\
112.7 \\
122.9 \\
133.1 \\
143.3\end{array}$ & $\begin{array}{l}103.6 \\
113.7 \\
123.9 \\
134.1 \\
144.3\end{array}$ & $\begin{array}{l}104.6 \\
114.7 \\
124.9 \\
135.2 \\
145.3\end{array}$ & $\begin{array}{l}105.6 \\
115.8 \\
125.9 \\
136.2 \\
146.3\end{array}$ \\
\hline $\begin{array}{l}150 \\
160 \\
170 \\
180 \\
190\end{array}$ & $\begin{array}{l}147.3 \\
157.3 \\
167.5 \\
177.5 \\
187.6\end{array}$ & $\begin{array}{l}148.3 \\
158.4 \\
168.5 \\
178.5 \\
188.6\end{array}$ & $\begin{array}{l}149.3 \\
159.4 \\
169.5 \\
179.5 \\
189.6\end{array}$ & $\begin{array}{l}150.3 \\
160.4 \\
170.5 \\
180.5 \\
190.6\end{array}$ & $\begin{array}{l}151.3 \\
161.4 \\
171 \cdot 5 \\
181 \cdot 5 \\
191.6\end{array}$ & $\begin{array}{l}152 \cdot 3 \\
162.4 \\
172.5 \\
182.5 \\
192.6\end{array}$ & $\begin{array}{l}153.3 \\
163.4 \\
173.5 \\
183.5 \\
193.6\end{array}$ & $\begin{array}{l}154.3 \\
164.4 \\
174.5 \\
184.5 \\
194.7\end{array}$ & $\begin{array}{l}155 \cdot 3 \\
165.4 \\
175.5 \\
185.5 \\
195.7\end{array}$ & $\begin{array}{l}156.3 \\
166.5 \\
176.5 \\
186.5 \\
196.7\end{array}$ \\
\hline $\begin{array}{l}200 \\
210 \\
220 \\
230 \\
240\end{array}$ & $\begin{array}{l}197.7 \\
207.9 \\
218.1 \\
228.4 \\
238.9\end{array}$ & $\begin{array}{l}198.8 \\
209.0 \\
219.1 \\
229.5 \\
239.9\end{array}$ & $\begin{array}{l}199.8 \\
210.0 \\
220.2 \\
230.5 \\
241.0\end{array}$ & $\begin{array}{l}200.8 \\
211.0 \\
221.2 \\
231.5 \\
242.0\end{array}$ & $\begin{array}{l}201.8 \\
212.0 \\
222.2 \\
232.6 \\
243.1\end{array}$ & $\begin{array}{l}202.8 \\
213.0 \\
223.2 \\
233.6 \\
244.1\end{array}$ & $\begin{array}{l}203.9 \\
214.0 \\
224.3 \\
234.6 \\
245.2\end{array}$ & $\begin{array}{l}204.9 \\
215.1 \\
225.3 \\
235.7 \\
246.3\end{array}$ & $\begin{array}{l}205.9 \\
216.1 \\
226.3 \\
236.8 \\
247.3\end{array}$ & $\begin{array}{l}206.9 \\
217.1 \\
227.4 \\
237.8 \\
248.4\end{array}$ \\
\hline $\begin{array}{l}250 \\
260 \\
270 \\
280\end{array}$ & $\begin{array}{l}249.5 \\
260.1 \\
270.4 \\
280.7 \\
291.6\end{array}$ & $\begin{array}{l}250.5 \\
261.1 \\
271.4 \\
281.7 \\
292.7\end{array}$ & $\begin{array}{l}251.6 \\
262.1 \\
272.4 \\
282.8 \\
293.8\end{array}$ & $\begin{array}{l}252.7 \\
263.2 \\
273.4 \\
283.9 \\
294.9\end{array}$ & $\begin{array}{l}253.7 \\
264.2 \\
274.5 \\
285.0\end{array}$ & $\begin{array}{l}254.8 \\
265.2 \\
275.5 \\
286.1\end{array}$ & $\begin{array}{l}255.8 \\
266.2 \\
276.5 \\
287.2\end{array}$ & $\begin{array}{l}256.9 \\
267.3 \\
277.5 \\
288.3\end{array}$ & $\begin{array}{l}258.0 \\
268.3 \\
278.6 \\
289.4\end{array}$ & $\begin{array}{l}259.0 \\
269.3 \\
279.6 \\
290.5\end{array}$ \\
\hline
\end{tabular}

\section{INPUT DATA:}

$\begin{array}{lllllllll}25.82 & 25.71 & 25.98 & 26.53 & 27.70 & 29.04 & 30.38 & 31.67 \\ 32.36 & 32.69 & 32.88 & 32.83 & 32.55 & 32.18 & 31.71 & 31.20 \\ 30.65 & 30.26 & 30.00 & 29.82 & 29.69 & 29.62 & 29.57 & 29.55 \\ 29.56 & 29.62 & 29.71 & 29.78 & 29.84 & 29.88 & 29.89 & 29.91 \\ 29.90 & 29.89 & 29.85 & 29.77 & 29.67 & 29.59 & 29.55 & 29.50 \\ 29.44 & 29.37 & 29.25 & 29.06 & 28.84 & 28.64 & 28.50 & 28.52 \\ 28.62 & 28.80 & 28.96 & 28.96 & 28.76 & 28.34 & 27.88 & \end{array}$


INST. NO. 79

AUGUST 24, 1981

GC TABLB

\begin{tabular}{|c|c|c|c|c|c|c|c|c|c|c|}
\hline $\mathbf{R}$ & 0 & 1 & 2 & 3 & 4 & 5 & 6 & 7 & 8 & \\
\hline $\begin{array}{l}0 \\
10 \\
20 \\
30 \\
40\end{array}$ & $\begin{array}{r}5.7 \\
17.6 \\
28.9 \\
39.4\end{array}$ & $\begin{array}{r}6.9 \\
18.7 \\
30.0 \\
40.5\end{array}$ & $\begin{array}{r}8.1 \\
19.9 \\
31.0 \\
41.5\end{array}$ & $\begin{array}{r}9.3 \\
21.0 \\
32.1 \\
42.5\end{array}$ & $\begin{array}{l}10.5 \\
22.2 \\
33.2 \\
43.4\end{array}$ & $\begin{array}{r}.0 \\
11.7 \\
23.3 \\
34.3 \\
44.4\end{array}$ & $\begin{array}{l}1.1 \\
12.8 \\
24.4 \\
35.4 \\
45.4\end{array}$ & $\begin{array}{r}2.3 \\
14.0 \\
25.5 \\
36.4 \\
46.4\end{array}$ & $\begin{array}{r}3.4 \\
15.2 \\
26.7 \\
37.4 \\
47.3\end{array}$ & $\begin{array}{r}4.6 \\
16.4 \\
27.8 \\
38.4 \\
48.3\end{array}$ \\
\hline $\begin{array}{l}50 \\
60 \\
70 \\
80 \\
90\end{array}$ & $\begin{array}{l}49.3 \\
58.5 \\
67.6 \\
76.9 \\
86.4\end{array}$ & $\begin{array}{l}50.2 \\
59.4 \\
68.6 \\
77.8 \\
87.3\end{array}$ & $\begin{array}{l}51.1 \\
60.4 \\
69.5 \\
78.8 \\
88.3\end{array}$ & $\begin{array}{l}52.1 \\
61.3 \\
70.4 \\
79.7 \\
89.3\end{array}$ & $\begin{array}{l}53.0 \\
62.2 \\
71.3 \\
80.7 \\
90.2\end{array}$ & $\begin{array}{l}54.0 \\
63.1 \\
72.3 \\
81.6 \\
91.2\end{array}$ & $\begin{array}{l}54.9 \\
64.0 \\
73.2 \\
82.6 \\
92.2\end{array}$ & $\begin{array}{l}55.8 \\
64.9 \\
74.1 \\
83: 5 \\
93.2\end{array}$ & $\begin{array}{l}56.7 \\
65.8 \\
75.0 \\
84.4 \\
94.2\end{array}$ & $\begin{array}{l}57.6 \\
66.7 \\
76.0 \\
85.4 \\
95.2\end{array}$ \\
\hline $\begin{array}{l}100 \\
110 \\
120 \\
130 \\
140\end{array}$ & $\begin{array}{r}96.2 \\
106.2 \\
116.2 \\
126.3 \\
136.3\end{array}$ & $\begin{array}{r}97.2 \\
107.2 \\
117.2 \\
127.3 \\
137.3\end{array}$ & $\begin{array}{r}98.2 \\
108.2 \\
118.3 \\
128.3 \\
138.3\end{array}$ & $\begin{array}{r}99.2 \\
109.2 \\
119.3 \\
129.3 \\
139.3\end{array}$ & $\begin{array}{l}100.2 \\
110.2 \\
120.3 \\
130.3 \\
140.3\end{array}$ & $\begin{array}{l}101.2 \\
111.2 \\
121.3 \\
131.3 \\
141.3\end{array}$ & $\begin{array}{l}102 \cdot 2 \\
112.2 \\
122 \cdot 3 \\
132 \cdot 3 \\
142.3\end{array}$ & $\begin{array}{l}103.2 \\
113.2 \\
123.3 \\
133.3 \\
143.3\end{array}$ & $\begin{array}{l}104.2 \\
114.2 \\
124.3 \\
134.3 \\
144.3\end{array}$ & $\begin{array}{l}105.2 \\
115.2 \\
125.3 \\
135.3 \\
145.3\end{array}$ \\
\hline $\begin{array}{l}150 \\
160 \\
170 \\
180 \\
190\end{array}$ & $\begin{array}{l}146.3 \\
156.2 \\
166.1 \\
176.0 \\
185.9\end{array}$ & $\begin{array}{l}147.3 \\
157.2 \\
167.1 \\
176.9 \\
186.9\end{array}$ & $\begin{array}{l}148.3 \\
158.2 \\
168.0 \\
177.9 \\
187.9\end{array}$ & $\begin{array}{l}149.3 \\
159.2 \\
169.0 \\
178.9 \\
188.9\end{array}$ & $\begin{array}{l}150.3 \\
160.2 \\
170.0 \\
179.9 \\
189.9\end{array}$ & $\begin{array}{l}151.3 \\
161.2 \\
171.0 \\
180.9 \\
190.9\end{array}$ & $\begin{array}{l}152.2 \\
162.1 \\
172.0 \\
181.9 \\
191.9\end{array}$ & $\begin{array}{l}153.2 \\
163.1 \\
173.0 \\
182.9 \\
192.9\end{array}$ & $\begin{array}{l}154.2 \\
164.1 \\
174.0 \\
183.9 \\
193.9\end{array}$ & $\begin{array}{l}155.2 \\
165.1 \\
175.0 \\
184.9 \\
194.9\end{array}$ \\
\hline $\begin{array}{l}200 \\
210 \\
220 \\
230 \\
240\end{array}$ & $\begin{array}{l}195.9 \\
206.0 \\
216.0 \\
226.1 \\
236.3\end{array}$ & $\begin{array}{l}196.9 \\
207.0 \\
217.0 \\
227.1 \\
237.4\end{array}$ & $\begin{array}{l}197.9 \\
208.0 \\
218.0 \\
228.1 \\
238.4\end{array}$ & $\begin{array}{l}198.9 \\
209.0 \\
219.0 \\
229.1 \\
239.5\end{array}$ & $\begin{array}{l}199.9 \\
210.0 \\
220.0 \\
230.2 \\
240.5\end{array}$ & $\begin{array}{l}200.9 \\
211.0 \\
221.0 \\
231.2 \\
241.6\end{array}$ & $\begin{array}{l}201.9 \\
212.0 \\
222.0 \\
232.2 \\
242.6\end{array}$ & $\begin{array}{l}202.9 \\
213.0 \\
223.1 \\
233.2 \\
243.7\end{array}$ & $\begin{array}{l}204 \\
214 \\
224 \\
234 \\
244\end{array}$ & $\begin{array}{l}205.0 \\
215.0 \\
225.1 \\
235.3 \\
245.7\end{array}$ \\
\hline $\begin{array}{l}250 \\
260 \\
270 \\
280 \\
280\end{array}$ & $\begin{array}{l}246.8 \\
257.1 \\
267.3 \\
277.6 \\
288.3\end{array}$ & $\begin{array}{l}247.8 \\
258.2 \\
268.4 \\
278.6 \\
289.4\end{array}$ & $\begin{array}{l}248.9 \\
259.2 \\
269.4 \\
279.7 \\
290.5\end{array}$ & $\begin{array}{l}249.9 \\
260.2 \\
270.4 \\
280.7 \\
291.6\end{array}$ & $\begin{array}{l}250.9 \\
261.2 \\
271.4 \\
281.8 \\
292.7\end{array}$ & $\begin{array}{l}252.0 \\
262.3 \\
272.4 \\
282.8 \\
293.9\end{array}$ & $\begin{array}{l}253.0 \\
263.3 \\
273.5 \\
283.9 \\
295.0\end{array}$ & $\begin{array}{l}254.1 \\
264.3 \\
274.5 \\
285.0\end{array}$ & $\begin{array}{l}255.1 \\
265.3 \\
275.5 \\
286.1\end{array}$ & $\begin{array}{l}256.1 \\
266.3 \\
276.5 \\
287.2\end{array}$ \\
\hline
\end{tabular}

INPUT DATA:

$\begin{array}{lllllllll}26.28 & 26.12 & 26.44 & 27.27 & 28.33 & 29.40 & 30.47 & 31.54 \\ 32.12 & 32.48 & 32.68 & 32.62 & 32.38 & 31.98 & 31.59 & 31.20 \\ 30.81 & 30.49 & 30.22 & 30.04 & 29.94 & 29.93 & 29.94 & 29.99 \\ 30.07 & 30.13 & 30.21 & 30.29 & 30.37 & 30.42 & 30.43 & 30.43 \\ 30.42 & 30.38 & 30.28 & 30.17 & 30.07 & 30.01 & 29.97 & 29.95 \\ 29.93 & 29.87 & 29.76 & 29.58 & 29.38 & 29.18 & 29.03 & 29.01 \\ 29.10 & 29.26 & 29.36 & 29.32 & 29.10 & 28.67 & 28.23 & \end{array}$


GD TABLB

\begin{tabular}{|c|c|c|c|c|c|c|c|c|c|c|}
\hline $\mathbf{R}$ & 0 & 1 & 2 & 3 & 4 & 5 & 6 & 7 & 8 & \\
\hline $\begin{array}{l}0 \\
10 \\
20 \\
30 \\
40\end{array}$ & $\begin{array}{r}5.7 \\
17.1 \\
28.2 \\
38.8\end{array}$ & $\begin{array}{r}6.9 \\
18.2 \\
29.3 \\
39.8\end{array}$ & $\begin{array}{r}8.0 \\
19.4 \\
30.4 \\
40.8\end{array}$ & $\begin{array}{r}9.1 \\
20.5 \\
31.5 \\
41.8\end{array}$ & $\begin{array}{l}10.3 \\
21.6 \\
32.5 \\
42.7\end{array}$ & $\begin{array}{r}.0 \\
11.4 \\
22.7 \\
33.6 \\
43.7\end{array}$ & $\begin{array}{r}1.1 \\
12.6 \\
23.8 \\
34.7 \\
44.7\end{array}$ & $\begin{array}{r}2.3 \\
13.7 \\
24.9 \\
35.7 \\
45.6\end{array}$ & $\begin{array}{r}3.4 \\
14.8 \\
26.0 \\
36.8 \\
46.6\end{array}$ & $\begin{array}{r}4.6 \\
16.0 \\
27.1 \\
37.8 \\
47.6\end{array}$ \\
\hline $\begin{array}{l}50 \\
60 \\
70 \\
80 \\
90\end{array}$ & $\begin{array}{l}48.5 \\
57.9 \\
67.1 \\
76.4 \\
85.9\end{array}$ & $\begin{array}{l}49.5 \\
58.8 \\
68.1 \\
77.4 \\
86.9\end{array}$ & $\begin{array}{l}50.4 \\
59.7 \\
69.0 \\
78.3 \\
87.9\end{array}$ & $\begin{array}{l}51.3 \\
60.7 \\
69.9 \\
79.3 \\
88.8\end{array}$ & $\begin{array}{l}52.3 \\
61.6 \\
70.8 \\
80.2 \\
89.8\end{array}$ & $\begin{array}{l}53.2 \\
62.5 \\
71.8 \\
81.2 \\
90.8\end{array}$ & $\begin{array}{l}54.2 \\
63.4 \\
72.7 \\
82.1 \\
91.8\end{array}$ & $\begin{array}{l}55.1 \\
64.4 \\
73.6 \\
83.1 \\
92.8\end{array}$ & $\begin{array}{l}56.0 \\
65.3 \\
74.6 \\
84.0 \\
93.8\end{array}$ & $\begin{array}{l}56.9 \\
66.2 \\
75.5 \\
85.0 \\
94.7\end{array}$ \\
\hline $\begin{array}{l}100 \\
110 \\
120 \\
130 \\
140\end{array}$ & $\begin{array}{r}95.7 \\
105.7 \\
115.6 \\
125.7 \\
135.6\end{array}$ & $\begin{array}{r}96.7 \\
106.6 \\
116.6 \\
126.7 \\
136.6\end{array}$ & $\begin{array}{r}97.7 \\
107.6 \\
117.7 \\
127.7 \\
137.6\end{array}$ & $\begin{array}{r}98.7 \\
108.6 \\
118.7 \\
128.7 \\
138.5\end{array}$ & $\begin{array}{r}99.7 \\
109.6 \\
119.7 \\
129.7 \\
139.5\end{array}$ & $\begin{array}{l}100.7 \\
120.6 \\
120.7 \\
130.7 \\
140.5\end{array}$ & $\begin{array}{l}101.7 \\
111.6 \\
121.7 \\
131.6 \\
141.5\end{array}$ & $\begin{array}{l}102.7 \\
112.6 \\
122.7 \\
132.6 \\
142.5\end{array}$ & $\begin{array}{l}103.7 \\
113.6 \\
123.7 \\
133.6 \\
143.5\end{array}$ & $\begin{array}{l}104.7 \\
114.6 \\
124.7 \\
134.6 \\
144.5\end{array}$ \\
\hline $\begin{array}{l}150 \\
160 \\
170 \\
180 \\
190\end{array}$ & $\begin{array}{l}145.4 \\
155.2 \\
165.0 \\
174.7 \\
184.5\end{array}$ & $\begin{array}{l}146.4 \\
156.2 \\
165.9 \\
175.7 \\
185.5\end{array}$ & $\begin{array}{l}147.4 \\
157.2 \\
166.9 \\
176.7 \\
186.5\end{array}$ & $\begin{array}{l}148.4 \\
158.2 \\
167.9 \\
177.7 \\
187.5\end{array}$ & $\begin{array}{l}149.4 \\
159.1 \\
168.8 \\
178.6 \\
188.5\end{array}$ & $\begin{array}{l}150.3 \\
160.1 \\
169.8 \\
179.6 \\
189.5\end{array}$ & $\begin{array}{l}151.3 \\
161.1 \\
170.8 \\
180.6 \\
190.5\end{array}$ & $\begin{array}{l}152.3 \\
162.0 \\
171.8 \\
181.6 \\
191.5\end{array}$ & $\begin{array}{l}153.3 \\
163.0 \\
172.8 \\
182.6 \\
192.4\end{array}$ & $\begin{array}{l}154.3 \\
164.0 \\
173.7 \\
183.6 \\
193.4\end{array}$ \\
\hline $\begin{array}{l}200 \\
210 \\
220 \\
230 \\
240\end{array}$ & $\begin{array}{l}194.4 \\
204.4 \\
214.4 \\
224.4 \\
234.4\end{array}$ & $\begin{array}{l}195.4 \\
205.4 \\
215.4 \\
225.4 \\
235.5\end{array}$ & $\begin{array}{l}196.4 \\
206.4 \\
216.4 \\
226.4 \\
236.5\end{array}$ & $\begin{array}{l}197.4 \\
207.4 \\
217.4 \\
227.4 \\
237.5\end{array}$ & $\begin{array}{l}198.4 \\
208 \cdot 4 \\
218.4 \\
228 \cdot 4 \\
238.5\end{array}$ & $\begin{array}{l}199.4 \\
209.4 \\
219.4 \\
229.4 \\
239.5\end{array}$ & $\begin{array}{l}200.4 \\
210.4 \\
220.4 \\
230.4 \\
240.5\end{array}$ & $\begin{array}{l}201.4 \\
211.4 \\
221.4 \\
231.4 \\
241.6\end{array}$ & $\begin{array}{l}202.4 \\
212.4 \\
222.4 \\
232 \cdot 4 \\
242.6\end{array}$ & $\begin{array}{l}203 \cdot 4 \\
213 \cdot 4 \\
223 \cdot 4 \\
233 \cdot 4 \\
243 \cdot 6\end{array}$ \\
\hline $\begin{array}{l}250 \\
260 \\
270 \\
280 \\
200\end{array}$ & $\begin{array}{l}244.6 \\
254.9 \\
265.1 \\
275.0 \\
285.8\end{array}$ & $\begin{array}{l}245.7 \\
255.9 \\
266.1 \\
276.1 \\
286.9\end{array}$ & $\begin{array}{l}246.7 \\
257.0 \\
267.0 \\
277.1 \\
288.0\end{array}$ & $\begin{array}{l}247.7 \\
258.0 \\
268.0 \\
278.1 \\
289.1\end{array}$ & $\begin{array}{l}248.7 \\
259.0 \\
269.0 \\
279.2 \\
290.2\end{array}$ & $\begin{array}{l}249.8 \\
260.0 \\
270.0 \\
280.3 \\
291.3\end{array}$ & $\begin{array}{l}250.8 \\
261.0 \\
271.0 \\
281.4 \\
292.5\end{array}$ & $\begin{array}{l}251.8 \\
262.0 \\
272.0 \\
282.4 \\
293.6\end{array}$ & $\begin{array}{l}252.9 \\
263.0 \\
273.0 \\
283.5 \\
294.7\end{array}$ & $\begin{array}{l}253.9 \\
264.1 \\
274.0 \\
284.6\end{array}$ \\
\hline
\end{tabular}

INPUT DATA:

$\begin{array}{lllllllll}26.79 & 26.73 & 27.07 & 27.75 & 28.64 & 29.56 & 30.47 & 31.37 \\ 31.97 & 32.20 & 32.33 & 32.29 & 32.15 & 31.85 & 31.52 & 31.20 \\ 30.89 & 30.61 & 30.38 & 30.22 & 30.13 & 30.12 & 30.16 & 30.22 \\ 30.31 & 30.43 & 30.58 & 30.68 & 30.77 & 30.82 & 30.85 & 30.83 \\ 30.82 & 30.74 & 30.63 & 30.50 & 30.38 & 30.30 & 30.24 & 30.21 \\ 30.18 & 30.15 & 30.10 & 30.02 & 29.88 & 29.71 & 29.55 & 29.47 \\ 29.46 & 29.62 & 29.77 & 29.68 & 29.38 & 28.90 & 28.42 & \end{array}$




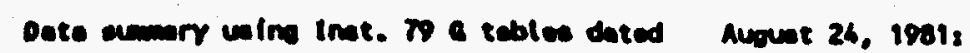

1.5 anver.0

$2.0400 \times 2.5$

2.540003 .2

xaoos5s:

xwo

$.209(.003)$

$.200(.001)$

.2001 .000

(3)

$.290(.000)$

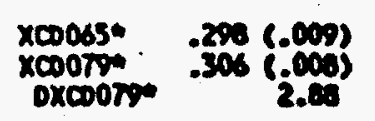

xn $065 * \quad .306(.002)$

oxh orom

Xc $0650.512(.003)$

Dxc oro

(.006)

$.2098 .002)$

$.305\left(\begin{array}{c}.002) \\ 1.93\end{array}\right.$

$.301(.002)$

$.302(.000)$

$.302(.001)$

$.301(.001)$

.307
.311
$(.001)$
$(.013)$

$.307(.000)$

$.315(.001)$

xo 065*

Do 070

$.326(.011)$
$.331(.011)$

(i.011)

$\left.\begin{array}{r}(.001) \\ (.002) \\ -.16\end{array}\right)$

$.316(.000) \quad .314(.001)$

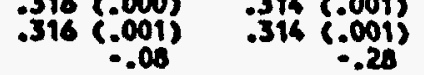

$.330(.002)$

$.328(.002)$

$.325(.001)$

$.326(.001)$

corr. maded to inat. $9 \mathrm{~g}$ values

杰

1

$\stackrel{\infty}{\mapsto}$

\begin{tabular}{|c|c|c|c|c|c|c|}
\hline & 1.33 & 1.73 & 2.23 & 2.08 & $1.15-2$ & \\
\hline 10 on 100 & -1.81 & -1.29 & $\cdot .60$ & & -1.26 & .166 \\
\hline & -.71 &.- .43 & -.10 & .29 & -.61 & .12 \\
\hline 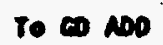 & -.18 & -.07 & .06 & .21 & -.07 & .190 \\
\hline
\end{tabular}

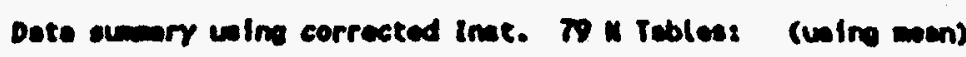

\begin{tabular}{|c|c|c|c|c|}
\hline & $1.15 \times 1 / 1.3$ & $1.500 \times 2.0$ & $2.040 \times 2.5$ & 2.540003 .2 \\
\hline 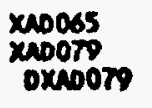 & $\begin{array}{c}.209(.003) \\
.302(.006) \\
.06\end{array}$ & $\begin{array}{c}.298(.001) \\
.290(.001) \\
.15\end{array}$ & 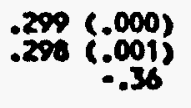 & $.208(.000)$ \\
\hline $\begin{array}{l}\text { xcooss } \\
\text { ropoto } \\
\text { oxcoors }\end{array}$ & $\begin{array}{c}.200 \\
.300 \\
.000 \\
.05\end{array}$ & $\begin{array}{c}.209(.002) \\
.300(.002) \\
.46\end{array}$ & $\begin{array}{c}.301\left(\begin{array}{c}.002 \\
.290(.000) \\
. .04\end{array}\right) \\
.000\end{array}$ & $\left.\begin{array}{c}.302 \\
.200 \\
. .001 \\
-1.15\end{array}\right)$ \\
\hline $\begin{array}{l}x \text { xa } 065 \\
x \text { ors } \\
\text { oxh ors }\end{array}$ & $\begin{array}{c}.306(.002) \\
.300(.002) \\
.22\end{array}$ & $\begin{array}{c}.307 \\
.307(.001) \\
(.000) \\
-.00\end{array}$ & 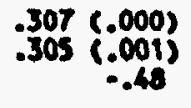 & $.306(.001)$ \\
\hline $\begin{array}{l}x C 065 \\
x C 079 \\
\text { Dxc ors }\end{array}$ & $\begin{array}{c}.312(.003) \\
.315(.003) \\
1.13\end{array}$ & $\begin{array}{c}.315(.001) \\
.316(.001) \\
.06\end{array}$ & $\begin{array}{r}.316(.000) \\
.314(.001) \\
. .76\end{array}$ & $\left.\begin{array}{c}.314 \\
.312(.001) \\
(.001) \\
. .05\end{array}\right)$ \\
\hline 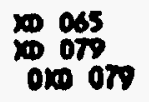 & $\begin{array}{c}.326(.011) \\
.330(.011)-\cdots \\
1.33\end{array}$ & 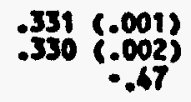 & 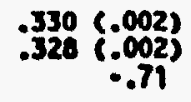 & $\begin{array}{c}.325(.001) \\
.326(.001) \\
. .52\end{array}$ \\
\hline
\end{tabular}

3.24044 .0

$.207(.001)$

$.293(-0.02)$

$.301(.001)$

$.290\left(\begin{array}{lll}0.01) \\ : 1.13\end{array}\right.$

30 (.001)

.301 (.0015

$.313(.000)$

$.310(.001)$

$.323(.001)$ $.321(.001)$

To 000 NoD

$\begin{array}{lll}-1.63 & -1.22 & -.74\end{array}$

$-1.20$

Yo $C O D N D O$

$\begin{array}{rrr}-.53 & -.36 & -.16\end{array}$

.08

$\cdot .35$

3.24004 .0

$.297(.001)$

$.201(.002)$

4.040 Us. 0

$.204(.000)$

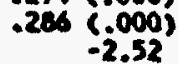

$.200(.003)$

.301 (.001)

$.200(.001)$

$-1.4$

$.306(.001)$ $(.001)$

$.202(.002)$

$.302(.000)$

.205
$.2 .000)$
-2.27

$.313(.000)$

.300 (.001)

$.311(.002)$

.306 (.001)

$.323(.001)$
.320
$(.001)$
.06

$.324(.000)$

$.310(.000)$

$-1.46$
1.158003 .2

.299 (.000) Armo-ch $.209(.002)$ ATHO-CA

.300 (.002) ATro-D $.0011)$ ATHO-OA
. .17 PERCENT

.306 (.001) ATHO-CH .307 (.001) ATMO-CM

.316 (.002) ATrío-On $.314(.001)$ ATHO-OA

.328 (.003) armo-ch $.328(.003)$ AIMO. OA

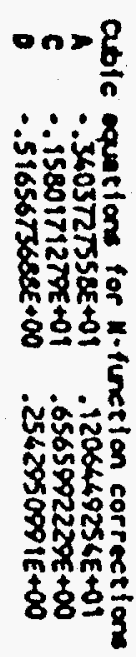

$\dot{8} \dot{8} \dot{\circ}$

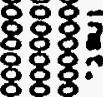

velue in breckete are atendard dorlations. MEY II ax as ass. Coef. epplled. 

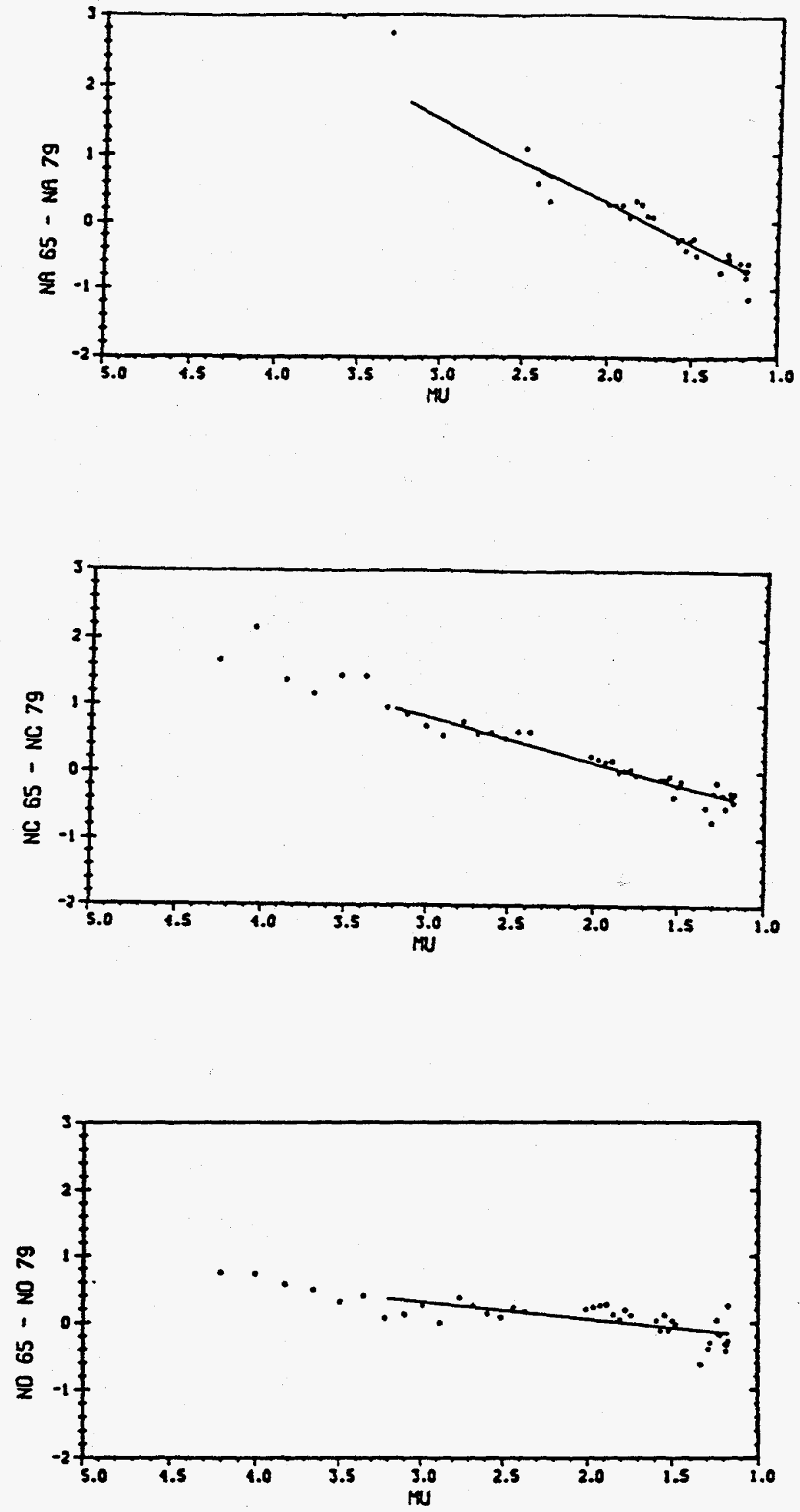

$I I-82$ 


\section{Appendix B}

SAMPLE RECORD OF DOBSON SPECTROPHOTOMETER STANDARD AND MERCURY LAMP TESTS DATA

WALLOPS ISLAND, VA, 1966-1995 
1. Reference Standard Lamp Readinge.

Dobson spectrophotometer No. 72

\begin{tabular}{|c|c|c|c|c|c|}
\hline LAMP & DATE & Ra & $\mathbf{R} \mathbf{c}$ & $\mathbf{R} \mathbf{c}^{\prime}$ & Rd \\
\hline \multicolumn{6}{|c|}{ Reference Standard Lamps } \\
\hline $72 \mathrm{~B}$ & $06 / 16 / 66$ & 29.6 & 31.9 & 62.3 & 33.5 \\
\hline $72 \mathrm{C}$ & $06 / 16 / 66$ & 25.3 & 29.2 & 62.2 & 31.6 \\
\hline $72 Y$ & $06 / 16 / 66$ & 25.8 & 28.7 & 64.3 & 31.1 \\
\hline 722 & $06 / 16 / 66$ & 1.8 & 26.2 & 64.9 & 29.2 \\
\hline $72 D$ & $05 / 27 / 69$ & 19 & 23.8 & 1.5 & 9.7 \\
\hline $72 E$ & $05 / 27 / 69$ & 16.9 & 21.9 & 64.8 & 26.3 \\
\hline $72 \omega$ & $05 / 27 / 69$ & 11.4 & 17.8 & 6.0 & 23.4 \\
\hline $72 x$ & $05 / 27 / 69$ & 17.1 & 22.0 & 65.2 & 26.2 \\
\hline $72 Y$ & $05 / 27 / 69$ & 15.1 & 20.4 & & 25.1 \\
\hline 722 & $05 / 27 / 69$ & 11.5 & 18.1 & & 23.3 \\
\hline 720 & $10 / 02 / 72$ & 23.2 & 27.4 & 63.6 & 31.2 \\
\hline $72 E$ & $10 / 02 / 72$ & 19.9 & 25.2 & 64.9 & 29.6 \\
\hline $72 Y$ & $10 / 02 / 72$ & 18.5 & 24.1 & 67.3 & 28.8 \\
\hline 722 & $10 / 02 / 72$ & 15.1 & 21.6 & 67.3 & 27.2 \\
\hline $72 \mathrm{D}$ & $05 / 19 / 76$ & 18.1 & 23.3 & & 27.7 \\
\hline $72 E$ & $05 / 19 / 76$ & 15.1 & 21.0 & 73.3 & 26.2 \\
\hline $72 Y$ & $05 / 19 / 76$ & 13.7 & 19.8 & 76.7 & 25.1 \\
\hline 722 & $05 / 19 / 76$ & 10.7 & 17.7 & 77.3 & 23.6 \\
\hline 7201 & $05 / 19 / 76$ & 4.6 & 12.2 & 89.6 & 18.9 \\
\hline 7202 & $05 / 29 / 76$ & 4.5 & 12.0 & 86.5 & 18.7 \\
\hline
\end{tabular}

Hg

REF

REE

REF

REE

REF

REF

REF

REF

REF

RE

REF

REF

REF

REF

REF

Dobson spectrophotometer No. 38

\begin{tabular}{cccccc}
$\begin{array}{c}\text { LAMP } \\
\text { Roference }\end{array}$ Standard & \multicolumn{2}{c}{ Ra } & Re & Ro' & Rd \\
Remps & & \\
$38 Q 1$ & $09 / 21 / 78$ & 32.4 & 34.4 & 64.6 & 36.5 \\
3802 & $09 / 21 / 78$ & 32.7 & 34.7 & 64.1 & 36.7 \\
$380 Q 1$ & $09 / 21 / 78$ & 33.7 & 35.8 & 63.5 & 37.0 \\
$380 Q 2$ & $09 / 21 / 78$ & 33.5 & 35.3 & 62.8 & 37.5 \\
$38 R 12$ & $09 / 21 / 78$ & 32.5 & 34.6 & $M$ & 36.5 \\
$38 R 13$ & $09 / 21 / 78$ & 32.4 & 34.4 & $M$ & 36.5 \\
$38 Q 1$ & $05 / 08 / 85$ & 25.7 & 27.8 & 36.7 & 29.7 \\
$38 Q 2$ & $05 / 08 / 85$ & 26.0 & 28.2 & 35.7 & 30.2 \\
3803 & $05 / 08 / 85$ & 25.4 & 27.7 & 38.0 & 29.5 \\
$380 Q 1$ & $05 / 08 / 85$ & 27.2 & 29.2 & 35.4 & 31.2 \\
$380 Q 3$ & $05 / 08 / 85$ & 26.0 & 28.0 & 38.3 & 30.0 \\
3801 & $09 / 16 / 91$ & 26.5 & 28.5 & 42.7 & 30.3 \\
3802 & $09 / 16 / 91$ & 27.7 & 29.8 & 38.0 & 31.6 \\
3803 & $09 / 16 / 91$ & 26.2 & 28.1 & 44.3 & 30.0 \\
$380 Q 1$ & $09 / 16 / 91$ & 27.8 & 29.8 & 41.2 & 31.7 \\
3801 & $04 / 27 / 95$ & 26.9 & 28.9 & 43.7 & 30.8 \\
$38 Q 2$ & $04 / 27 / 95$ & 27.5 & 29.4 & 42.0 & 31.4
\end{tabular}

STN

Na Nc

55.926 .2 $\begin{array}{lllll}21.5 & 24.7 & 55.8 & 24.4\end{array}$ $\begin{array}{lllll}22.0 & 24.2 & 57.7 & 24.0\end{array}$ $\begin{array}{lllll}18.0 & 21.7 & 58.2 & 22.1\end{array}$ 28.929 .467 .729 .3 $\begin{array}{llll}26.0 & 27.4 & 68.8 & 27.9\end{array}$ $\begin{array}{llll}20.0 & 23.1 & 69.9 & 24.9\end{array}$ $\begin{array}{llll}26.2 & 27.5 & 69.2 & 27.8\end{array}$ $24.025 .8 \quad 70.426 .7$ $20.123 .4 \quad 70.5 \quad 24.8$ $26.127 .8 \quad 62.526 .6$ $\begin{array}{lllll}22.7 & 25.5 & 63.7 & 25.1\end{array}$ $21.224 .4 \quad 65.824 .3$ $\begin{array}{lllll}17.6 & 21.8 & 65.8 & 22.7\end{array}$ $\begin{array}{lllll}29.5 & 30.7 & 78.0 & 29.3\end{array}$ $\begin{array}{llll}26.2 & 28.2 & 78.6 & 27.7\end{array}$ $\begin{array}{lllll}24.6 & 26.9 & 81.7 & 26.6\end{array}$ $\begin{array}{lllll}21.2 & 24.7 & 82.2 & 25.0\end{array}$ 14.224 .702 .225 .0 $14.1 \quad 18.4 \quad 90.5 \quad 19.9$

$10.9 \quad 16.1 \quad 46.6 \quad 18.0$ $11.2 \quad 16.4 \quad 46.1 \quad 18.2$ $12.3 \quad 17.6 \quad 43.5 \quad 19.4$ $12.1 \quad 17.1 \quad 44.819 .1$ 11.016 .3 M 18.0 $10.916 .1 \quad M \quad 18.0$ $\begin{array}{lllll}12.0 & 16.8 & 26.7 & 18.3\end{array}$ $\begin{array}{lllll}12.3 & 17.2 & 25.6 & 18.8\end{array}$ $\begin{array}{lllll}11.7 & 16.7 & 28.1 & 18.0\end{array}$ $\begin{array}{llll}13.7 & 18.3 & 25.3 & 20.0\end{array}$ $\begin{array}{llll}12.3 & 17.0 & 28.5 & 18.6\end{array}$ 10.916 .131 .918 .7 $12.2 \quad 17.6 \quad 26.720 .2$ $\begin{array}{lllll}10.5 & 15.7 & 33.6 & 18.4\end{array}$ $\begin{array}{llll}12.3 & 17.6 & 30.2 & 20.3\end{array}$ $10.2 \quad 15.6 \quad 32.0 \quad 17.9$ $10.8 \quad 16.2 \quad 30.1 \quad 18.6$ 
Dobson Spectrophotometer No. 38

$\begin{array}{cccccc}\text { LAMP } & \text { DATE } & \text { Ra Rc } & \text { Rc' } & \text { Rd } \\ \text { Reference Standard Lamps } & & \\ 38 Q 3 & 04 / 27 / 95 & 26.7 & 28.6 & 44.9 & 30.6 \\ 38001 & 04 / 27 / 95 & 28.3 & 30.3 & 41.3 & 32.3 \\ 38002 & 04 / 27 / 95 & 27.9 & 29.8 & 41.4 & 31.8 \\ 38007 & 04 / 27 / 95 & 27.2 & 28.8 & 44.1 & 30.9 \\ 38008 & 04 / 27 / 95 & 27.0 & 28.8 & 44.2 & 30.8\end{array}$

Hg

REF

REF

REF

$\begin{array}{llllll}38008 & 04 / 27 / 95 & 27.0 & 28.8 & 44.2 & 30.8\end{array}$

Dobson Spectrophotometer No. 86

$\begin{array}{cccccc}\text { LAMP } & \text { DATE } & \text { Ra } & \text { Re } & \text { Rc' } & \text { Rd } \\ \text { Reference Standard Lamps } & & \\ 8601 & 05 / 26 / 83 & 42.6 & 40.4 & 67.1 & 38.7 \\ 8602 & 05 / 26 / 83 & 42.7 & 40.4 & 67.2 & 38.5 \\ 8603 & 05 / 26 / 83 & 42.8 & 40.6 & 66.4 & 38.6 \\ 86001 & 05 / 26 / 83 & 44.2 & 41.8 & 65.2 & 40.2 \\ 86002 & 05 / 26 / 83 & 43.7 & 41.3 & 64.8 & 39.7 \\ 860 Q 3 & 05 / 26 / 83 & 42.8 & 40.7 & 66.4 & 38.8\end{array}$

REF
STN Na Nc Nc' Nd

$\begin{array}{llll}9.9 & 15.3 & 33.3 & 17.7\end{array}$ $\begin{array}{llll}11.3 & 16.6 & 29.5 & 19.0\end{array}$

$\begin{array}{llll}10.5 & 15.5 & 32.4 & 18.0\end{array}$

$10.3 \quad 15.5 \quad 32.5 \quad 17.9$

STN

Na Na

Ne' No

dd

$\begin{array}{lllll}11.8 & 16.5 & 44.6 & 18.4\end{array}$

$\begin{array}{lllll}11.9 & 16.5 & 44.7 & 18.2\end{array}$

$\begin{array}{lllll}12.0 & 16.7 & 43.9 & 18.3\end{array}$

$\begin{array}{lllll}13.6 & 18.0 & 42.7 & 20.1\end{array}$

$\begin{array}{llll}13.0 & 17.5 & 42.2 & 19.5\end{array}$

$\begin{array}{llll}12.0 & 16.8 & 43.9 & 18.5\end{array}$ $\begin{array}{llll}11.7 & 17.2 & 29.4 & 19.6\end{array}$

dNa dNe dNc' dNd

dNad dNed

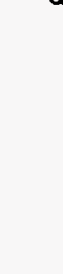

dNa dNe dNc dNd dNad dNed 
2. Monthly Standard Lamp and Mercury Lamp Test Data.

Dobson Spectrophotometer No. 72

\begin{tabular}{|c|c|c|c|c|c|c|c|c|c|c|c|c|c|c|c|c|c|}
\hline LAMP & DATE & Ra & Rc & $\mathbf{R} \mathbf{c}^{\prime}$ & Rd & $\mathbf{H g}$ & STN & Na & $\mathrm{Ne}$ & $N c^{\prime}$ & Nd & $\mathrm{dNa}_{\mathbf{a}}$ & dNc 0 & dNce & dNd & dNad & dNed \\
\hline $72 B$ & $06 / 16 / 66$ & 29.6 & 31.9 & 62.3 & 33.5 & & & 25.7 & 27.3 & 55.9 & 26.2 & .0 & .0 & .0 & .0 & .0 & .0 \\
\hline $72 \mathrm{C}$ & $06 / 16 / 66$ & 25.3 & 29.2 & 62.2 & 31.6 & & & 21.5 & 24.7 & 55.8 & 24.4 & .0 & .0 & .0 & .0 & .0 & .0 \\
\hline $72 Y$ & $06 / 16 / 66$ & 25.8 & 28.7 & 64.3 & 31.1 & & & 22.0 & 24.2 & 57.7 & 24.0 & .0 & .0 & .0 & .0 & .0 & .0 \\
\hline 722 & $06 / 16 / 66$ & 21.8 & 26.2 & 64.9 & 29.2 & & & 18.0 & 21.7 & 58.2 & 22.1 & .0 & .0 & .0 & .0 & .0 & .0 \\
\hline $72 B$ & $06 / 21 / 67$ & 26.8 & 29.5 & 62.7 & 31.4 & $\bullet$ & WAI & 23.0 & 25.0 & 56.3 & 24.2 & 2.7 & 2.3 & -.4 & 2.0 & .7 & .3 \\
\hline $72 \mathrm{C}$ & $06 / 21 / 67$ & 23.5 & 27.6 & 60.3 & 30.7 & $+0.44 "$ & WAI & 19.7 & 23.1 & 54.1 & 23.6 & 1.8 & 1.6 & 1.7 & .8 & 1.0 & .8 \\
\hline $72 Y$ & $06 / 21 / 67$ & 24.0 & 27.1 & 64.2 & 29.7 & & WAI & 20.2 & 22.6 & 57.6 & 22.6 & 1.8 & 1.6 & .1 & 1.4 & .4 & .2 \\
\hline 722 & $06 / 21 / 67$ & 20.2 & 24.6 & 64.1 & 27.8 & & WAI & 16.4 & 20.2 & 57.5 & 20.8 & 1.6 & 1.5 & .7 & 1.3 & .3 & .2 \\
\hline 722 & $06 / 21 / 67$ & 20.2 & 24.6 & 64.2 & 27.9 & & WA I & 16.4 & 20.2 & 57.6 & 20.9 & 1.6 & 1.5 & .6 & 1.2 & .4 & .3 \\
\hline 722 & $06 / 21 / 67$ & 20.2 & 24.5 & 64.4 & 27.8 & & WAI & 16.9 & 20.1 & 57.8 & 20.8 & 1.6 & 1.6 & .4 & 1.3 & .3 & .3 \\
\hline $72 B$ & $06 / 22 / 67$ & 27.4 & 29.8 & 61.6 & 31.7 & +0.50 & WAI & 23.6 & 25.3 & 55.3 & 24.5 & 2.1 & 2.0 & .6 & 1.7 & .4 & .3 \\
\hline $72 B$ & $06 / 23 / 67$ & 27.4 & 29.8 & 61.4 & 31.7 & +0.63 & WAI & 23.6 & 25.3 & 55.1 & 24.5 & 2.1 & 2.0 & .8 & 1.7 & .4 & .3 \\
\hline $72 \mathrm{~B}$ & $06 / 24 / 67$ & 27.1 & 29.5 & 62.1 & 31.4 & & WAI & 23.3 & 25.0 & 55.7 & 24.2 & 2.4 & 2.3 & .2 & 2.0 & .4 & .3 \\
\hline $72 B$ & $06 / 25 / 67$ & 26.5 & 29.2 & 62.3 & 31.1 & +0.52 & WAI & 22.7 & 24.7 & 55.9 & 24.0 & 3.0 & 2.6 & .0 & 2.2 & .8 & .4 \\
\hline $72 B$ & $06 / 30 / 67$ & 27.0 & 29.8 & 60.8 & 31.7 & +0.69 & WAI & 23.2 & 25.3 & 54.5 & 24.5 & 2.5 & 2.0 & 1.4 & 1.7 & .8 & .3 \\
\hline $72 B$ & $08 / 05 / 67$ & 25.2 & 27.8 & 79.7 & 29.8 & +0.38 & WAI & 21.4 & 23.3 & 71.6 & 22.7 & 4.3 & $4.0-?$ & -15.7 & 3.5 & .8 & .5 \\
\hline $72 \mathrm{C}$ & $08 / 07 / 67$ & 21.0 & 25.0 & 78.3 & 28.4 & $\bullet$ & WAI & 17.2 & 20.6 & 70.4 & 21.4 & 4.3 & $4.1=$ & -14.6 & 3.0 & 1.3 & 1.1 \\
\hline $72 B$ & $08 / 09 / 67$ & 24.7 & 27.6 & 78.8 & 29.7 & +0.27 & WAI & 20.9 & 23.1 & 70.8 & 22.6 & 4.8 & $4.2-$ & -14.9 & 3.6 & 1.2 & .6 \\
\hline $72 \mathrm{C}$ & $10 / 17 / 67$ & 20.6 & 24.8 & 66.3 & 28.2 & +0.52 & WAI & 16.8 & 20.4 & 59.5 & 21.2 & 4.7 & 4.3 & -3.7 & 3.2 & 1.5 & 1.1 \\
\hline $72 \mathrm{C}$ & $10 / 17 / 67$ & 21.5 & 25.8 & 62.6 & 29.3 & & WAI & 17.7 & 21.3 & 56.2 & 22.2 & 3.8 & 3.4 & -.4 & 2.2 & 1.6 & 1.2 \\
\hline $72 c$ & $12 / 15 / 67$ & & & & & +0.32 & WAI & & & & & & & & & & \\
\hline $72 \mathrm{C}$ & $01 / 04 / 68$ & 20.0 & 24.6 & 61.8 & 28.6 & +0.16 & WAI & 16.2 & 20.2 & 55.4 & 21.6 & 5.3 & 4.5 & .4 & 2.8 & 2.5 & 1.7 \\
\hline $72 c$ & $01 / 29 / 68$ & 17.2 & 21.2 & 54.4 & 24.5 & +0.33 & WAI & 13.4 & 16.8 & 48.6 & 17.6 & 8.1 & 7.9 & 7.2 & 6.8 & 1.3 & 1.1 \\
\hline $72 \mathrm{C}$ & $01 / 29 / 68$ & 17.3 & 21.4 & 54.3 & 24.6 & & WAI & 13.5 & 17.0 & 48.5 & 17.7 & 8.0 & 7.7 & 7.3 & 6.7 & 1.3 & 1.0 \\
\hline $72 \mathrm{C}$ & $05 / 08 / 68$ & 17.6 & 22.2 & 57.4 & 26.0 & +0.25 & WAI & 13.8 & 17.8 & 51.4 & 19.0 & 7.7 & 6.9 & 4.4 & 5.4 & 2.3 & 1.5 \\
\hline $72 \mathrm{C}$ & $05 / 08 / 68$ & 16.5 & 22.0 & 57.4 & 26.0 & & WAI & 12.7 & 17.6 & 51.4 & 19.0 & 8.8 & 7.1 & 4.4 & 5.4 & 3.4 & 1.7 \\
\hline $72 C$ & $05 / 29 / 68$ & 17.4 & 22.3 & 55.5 & 26.5 & +0.07 & WAI & 13.6 & 17.9 & 49.6 & 19.5 & 7.9 & 6.8 & 6.2 & 4.9 & 3.0 & 1.9 \\
\hline $72 C$ & $07 / 03 / 68$ & 18.1 & 23.7 & 49.5 & 28.0 & +0.19 & WAI & 14.3 & 19.3 & 44.0 & 21.0 & 7.2 & 5.4 & 11.8 & 3.4 & 3.8 & 2.0 \\
\hline $72 \mathrm{C}$ & $07 / 05 / 68$ & 18.2 & 23.2 & 49.6 & 27.7 & & WAI & 14.4 & 18.8 & 44.1 & 20.7 & 7.1 & 5.9 & 11.7 & 3.7 & 3.4 & 2.2 \\
\hline $72 \mathrm{C}$ & $08 / 15 / 68$ & 17.8 & 23.2 & 50.6 & 27.8 & +0.24 & WAI & 14.0 & 18.8 & 45.1 & 20.8 & 7.5 & 5.9 & 10.7 & 3.6 & 3.9 & 2.3 \\
\hline $72 \mathrm{C}$ & $08 / 17 / 68$ & 17.9 & 23.6 & 48.7 & 28.3 & +0.09 & WAI & 14.1 & 19.2 & 43.3 & 21.3 & 7.4 & 5.5 & 12.5 & 3.1 & 4.3 & 2.4 \\
\hline 720 & $08 / 17 / 68$ & 14.6 & 20.5 & 53.8 & 25.6 & & WAI & 10.7 & 16.1 & 48.1 & 18.6 & & & & & & \\
\hline $72 x$ & $08 / 17 / 68$ & 18.2 & 23.0 & 53.0 & 27.4 & & WAI & 14.4 & 18.6 & 47.3 & 20.4 & 7.6 & 5.6 & 10.4 & 3.6 & 4.0 & 2.0 \\
\hline 722 & $08 / 17 / 68$ & 14.7 & 20.4 & 54.1 & 25.7 & & WAI & 10.8 & 16.0 & 48.3 & 18.7 & 7.2 & 5.7 & 9.9 & 3.4 & 3.8 & 2.3 \\
\hline $\begin{array}{l}72 C \\
72 D\end{array}$ & $\begin{array}{l}08 / 18 / 68 \\
08 / 18 / 68\end{array}$ & $\begin{array}{l}17.8 \\
14.5\end{array}$ & $\begin{array}{l}23.7 \\
20.6\end{array}$ & $\begin{array}{l}49.4 \\
53.1\end{array}$ & $\begin{array}{l}28.4 \\
25.6\end{array}$ & +0.06 & $\begin{array}{l}\text { WAI } \\
\text { WAI }\end{array}$ & $\begin{array}{l}14.0 \\
10.6\end{array}$ & $\begin{array}{l}19.3 \\
16.2\end{array}$ & $\begin{array}{l}43.9 \\
47.4\end{array}$ & $\begin{array}{l}21.4 \\
18.6\end{array}$ & 7.5 & 5.4 & 11.9 & 3.0 & 4.5 & 2.4 \\
\hline $72 Y$ & $08 / 18 / 68$ & 18.5 & 23.2 & 52.3 & 27.7 & & WAI & 14.7 & 18.8 & 46.6 & 20.7 & 7.3 & 5.4 & 11.1 & 3.3 & 4.0 & 2.1 \\
\hline 722 & $08 / 18 / 68$ & 14.8 & 20.7 & 53.7 & 25.7 & & WAI & 10.9 & 16.3 & 48.0 & 18.7 & 7.1 & 5.4 & 10.2 & 3.4 & 3.7 & 2.0 \\
\hline $72 \mathrm{C}$ & $08 / 29 / 68$ & 18.3 & 23.9 & 48.0 & 28.6 & +0.10 & WAI & 14.5 & 19.5 & 42.6 & 21.6 & 7.0 & 5.2 & 13.2 & 2.8 & 4.2 & 2.4 \\
\hline $72 \mathrm{C}$ & $10 / 02 / 68$ & 17.0 & 22.7 & 45.7 & 27.6 & -0.02 & WAI & 13.2 & 18.3 & 40.4 & 20.6 & 8.3 & 6.4 & 15.4 & 3.8 & 4.5 & 2.6 \\
\hline $72 C$ & $10 / 30 / 68$ & 17.3 & 22.6 & 43.0 & 26.1 & +0.10 & WAI & 13.5 & 18.2 & 37.9 & 19.1 & 8.0 & 6.5 & 17.9 & 5.3 & 2.7 & 1.2 \\
\hline $72 \mathrm{C}$ & $12 / 02 / 68$ & 17.4 & 22.9 & 40.7 & 27.4 & +0.27 & WAI & 13.6 & 18.5 & 35.7 & 20.4 & 7.9 & 6.2 & 20.1 & 4.0 & 3.9 & 2.2 \\
\hline $72 \mathrm{D}$ & $02 / 04 / 69$ & 14.2 & 21.2 & 40.6 & 26.7 & -0.17 & WAI & 10.3 & 16.8 & 35.6 & 19.7 & & & & & & \\
\hline $72 Y$ & $04 / 23 / 69$ & 15.3 & 20.8 & 69.4 & 25.4 & -1.38 & BDR & 11.4 & 16.4 & 62.3 & 18.5 & 10.6 & 7.8 & -4.6 & 5.5 & 5.1 & 2.3 \\
\hline $72 x$ & $04 / 25 / 69$ & 17.3 & 22.3 & 66.0 & 26.5 & -1.57 & BDR & 13.5 & 17.9 & 59.2 & 19.5 & & & & & & \\
\hline $72 Y$ & $04 / 25 / 69$ & 25.1 & 20.4 & 67.8 & 25.1 & -1.59 & BDR & 11.2 & 16.0 & 60.9 & 18.2 & 10.8 & 8.2 & -3.2 & 5.8 & 5.0 & 2.4 \\
\hline
\end{tabular}


Dobson Spectrophotometer No. 72

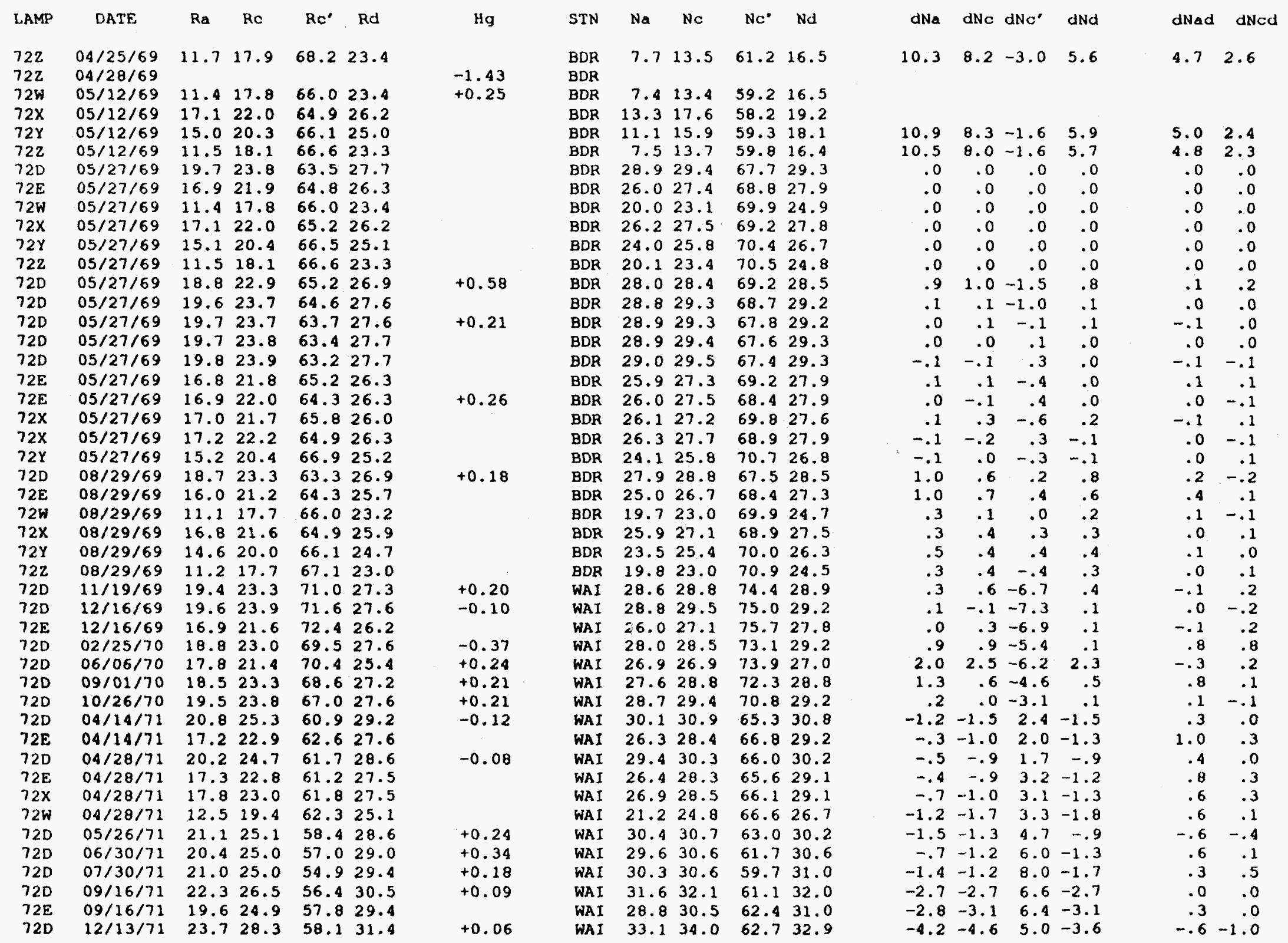


Dobson Spectrophotometer No. 72

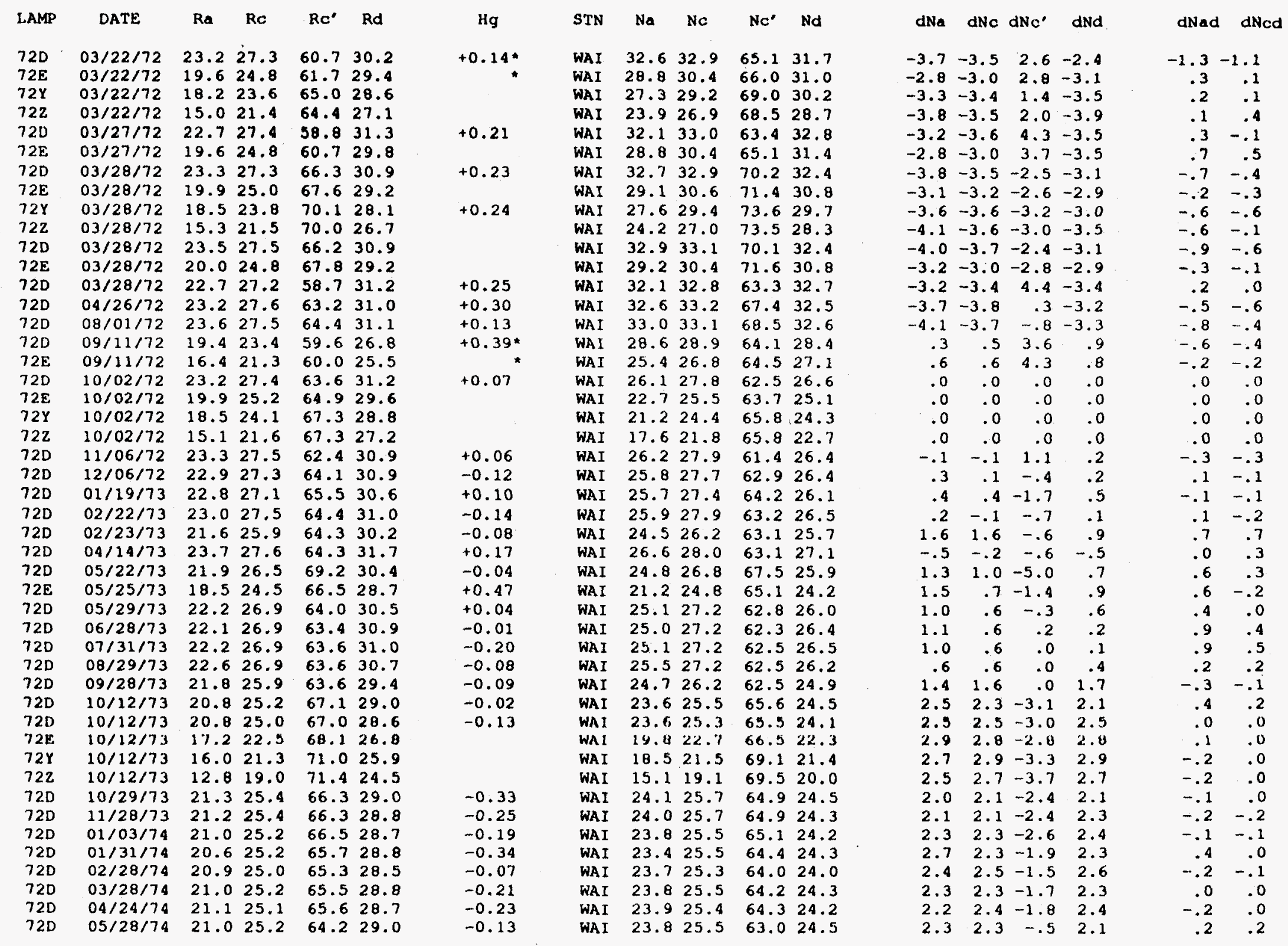


Dobson Spect rophot ometer No. 72

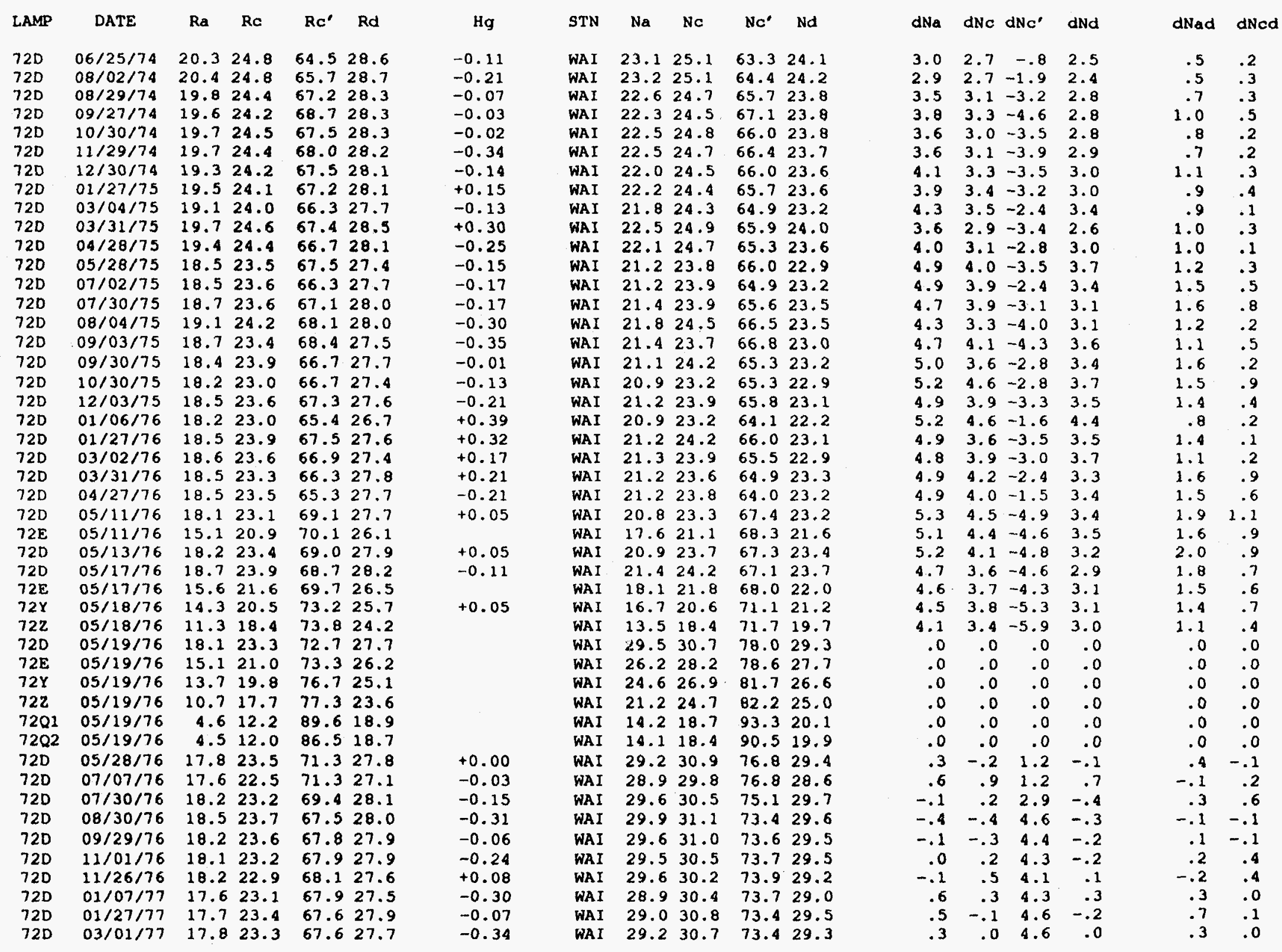


Dobson spect rophotometer No. 72

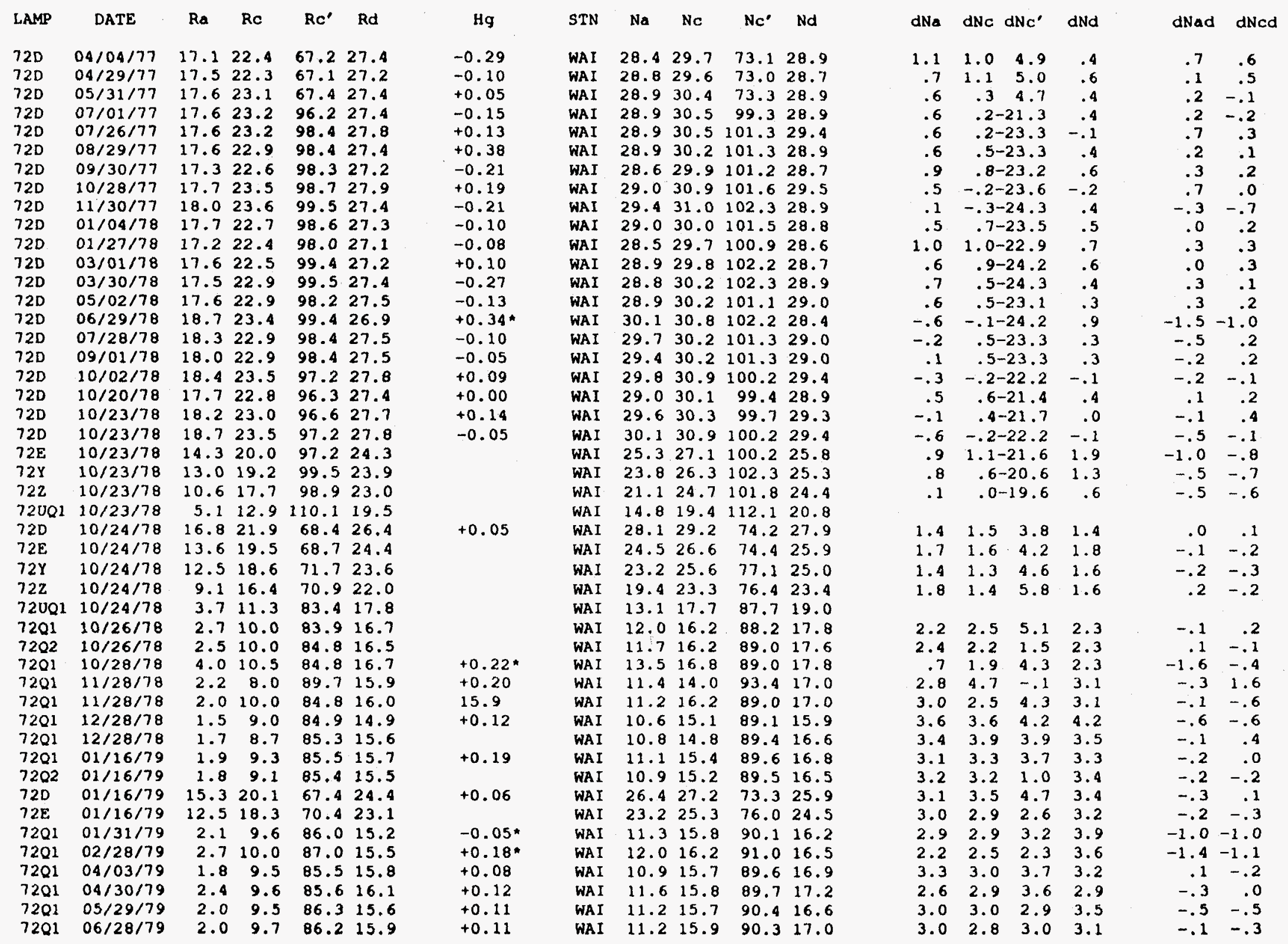


Dobson Spectrophotometer No. 72

\begin{tabular}{lclrrrr} 
LAMP & DATE & Ra & \multicolumn{1}{c}{ Re } & \multicolumn{1}{c}{ Re' } & Rd & Hg \\
$72 Q 1$ & $07 / 29 / 79$ & 2.1 & 9.2 & 86.8 & 15.6 & +0.06 \\
7201 & $08 / 28 / 79$ & 2.8 & 9.9 & 84.9 & 16.1 & +0.12 \\
7201 & $09 / 28 / 79$ & 2.6 & 10.0 & 84.0 & 16.1 & +0.16 \\
7201 & $10 / 29 / 79$ & 2.6 & 9.9 & 84.7 & 16.4 & +0.33 \\
7201 & $02 / 26 / 80$ & & & & & -1.47 \\
7201 & $02 / 26 / 80$ & & & & & -0.40 \\
$72 Q 1$ & $02 / 29 / 80$ & 1.8 & 9.2 & 84.5 & 15.3 & -0.08 \\
$720 Q 1$ & $02 / 29 / 80$ & $\mathbf{2 . 8}$ & $\mathbf{1 0 . 2}$ & $\mathbf{8 3 . 2}$ & 16.5 &
\end{tabular}

Dobson Spectrophotometer No. 38

\begin{tabular}{|c|c|c|c|c|c|c|c|c|c|c|c|}
\hline LAMP & DATE & Ra & Rc & $\mathbf{R o}^{\prime}$ & Rd & $\mathrm{Hg}$ & STN & Na & No & $\mathrm{No}^{\prime}$ & Nd \\
\hline $38 Q 1$ & $09 / 21 / 78$ & 32.4 & 34.4 & 64.6 & 36.5 & +0.08 & BDR & 10.9 & 16.1 & 46.6 & 18.0 \\
\hline $38 Q 2$ & $09 / 21 / 78$ & 32.7 & 34.7 & 64.1 & 36.7 & & BDR & 11.2 & 16.4 & 46.1 & 18.2 \\
\hline $380 Q 1$ & $09 / 21 / 78$ & 33.7 & 35.8 & 63.5 & 37.8 & & BDR & 12.3 & 17.6 & 45.5 & 19.4 \\
\hline 38002 & $09 / 21 / 78$ & 33.5 & 35.3 & 62.8 & 37.5 & & BDR & 12.1 & 17.1 & 44.8 & 19.1 \\
\hline $38 Q 1$ & $10 / 29 / 79$ & 32.3 & 34.4 & 66.8 & 36.3 & -0.10 & WAI & 10.8 & 16.1 & 48.8 & 17.8 \\
\hline 3801 & $11 / 29 / 79$ & 31.9 & 34.3 & 66.1 & 36.2 & -0.11 & WAI & 10.4 & 16.0 & 48.1 & 17.7 \\
\hline $38 Q 1$ & $01 / 02 / 80$ & 32.1 & 34.4 & 66.0 & 36.6 & -0.08 & WAI & 10.6 & 16.1 & 48.0 & 18.1 \\
\hline $38 Q 1$ & $01 / 28 / 80$ & 32.5 & 34.5 & 65.6 & 36.7 & -0.05 & WAI & 11.0 & 16.2 & 47.6 & 18.2 \\
\hline $38 Q 1$ & $02 / 29 / 80$ & 32.2 & 34.6 & 65.6 & 36.4 & +0.06 & WAI & 10.7 & 16.3 & 47.6 & 17.9 \\
\hline $38 Q 1$ & $03 / 28 / 80$ & 32.5 & 34.6 & 65.7 & 36.7 & -0.01 & WAI & 11.0 & 16.3 & 47.7 & 18.2 \\
\hline $38 Q 1$ & $04 / 28 / 80$ & 32.5 & 34.9 & 66.2 & 36.8 & -0.26 & WAI & 11.0 & 16.7 & 48.2 & 18.3 \\
\hline 3801 & $05 / 28 / 80$ & 32.1 & 34.6 & 65.3 & 36.2 & -0.23 & WAI & 10.6 & 16.3 & 47.3 & 17.7 \\
\hline 3801 & $06 / 27 / 80$ & 32.6 & 34.9 & 66.4 & 37.1 & -0.32 & WAI & 11.1 & 16.7 & 48.4 & 18.6 \\
\hline $38 Q 1$ & $07 / 28 / 80$ & 33.1 & 35.4 & 66.0 & 37.5 & -0.29 & WAI & 11.7 & 17.2 & 48.0 & 19.1 \\
\hline 3801 & $08 / 28 / 80$ & 32.8 & 35.1 & 66.1 & 37.4 & -0.14 & WAI & 11.4 & 16.9 & 48.1 & 19.0 \\
\hline $38 Q 1$ & $09 / 29 / 80$ & 33.2 & 35.4 & 65.9 & 37.5 & -0.25 & WAI & 11.8 & 17.2 & 47.9 & 19.1 \\
\hline $38 Q 1$ & $10 / 28 / 80$ & 33.3 & 35.5 & 65.2 & 37.6 & -0.33 & WAI & 11.9 & 17.3 & 47.2 & 19.2 \\
\hline $38 Q 1$ & $11 / 28 / 80$ & 33.4 & 35.7 & 64.8 & 38.0 & -0.28 & WAI & 12.0 & 17.5 & 46.8 & 19.6 \\
\hline 3801 & $12 / 30 / 80$ & 33.5 & 35.6 & 64.5 & 37.9 & -0.24 & WAI & 12.1 & 37.4 & 46.5 & 19.5 \\
\hline 38Q1 & $01 / 28 / 81$ & 33.5 & 35.9 & 64.5 & 38.0 & -0.18 & WAI & 12.1 & 17.7 & 46.5 & 19.6 \\
\hline $38 Q 1$ & $02 / 28 / 81$ & 33.3 & 35.6 & 65.0 & 37.8 & -0.13 & WAI & 11.9 & 17.4 & 47.0 & 19.4 \\
\hline 38Q1 & $03 / 28 / 81$ & 33.4 & 35.7 & 64.2 & 37.8 & -0.21 & WAI & 12.0 & 17.5 & 46.2 & 19.4 \\
\hline $38 Q 1$ & $04 / 29 / 81$ & 31.3 & 33.9 & 68.0 & 35.9 & -0.28 & WAI & 9.8 & 15.6 & 50.0 & 17.4 \\
\hline 38Q2 & $04 / 29 / 81$ & 31.4 & 33.8 & 67.5 & 35.9 & & WAI & 9.9 & 15.5 & 49.5 & 17.4 \\
\hline 3801 & $04 / 30 / 81$ & 31.4 & 33.7 & 67.4 & 35.9 & -0.25 & WAI & 9.9 & 15.4 & 49.4 & 17.4 \\
\hline $38 Q 2$ & $04 / 30 / 81$ & 31.7 & 34.0 & 66.6 & 36.2 & & WAI & 10.2 & 15.7 & 48.6 & 17.7 \\
\hline $38 Q 1$ & $04 / 30 / 81$ & 31.7 & 34.1 & 67.0 & 36.2 & & WAI & 10.2 & 15.8 & 49.0 & 17.7 \\
\hline $38 Q 1$ & $05 / 01 / 81$ & 30.1 & 32.3 & 63.3 & 34.6 & -0.60 & WAI & 8.6 & 14.0 & 45.3 & 16.0 \\
\hline $38 Q 1$ & $05 / 04 / 81$ & 30.0 & 32.4 & 64.9 & 34.7 & -0.08 & WAI & 8.5 & 14.1 & 46.9 & 16.1 \\
\hline $38 Q 1$ & $05 / 04 / 81$ & 31.1 & 33.5 & 63.9 & 35.6 & 0.57 & WAI & 9.6 & 15.2 & 15.9 & $1 \% .1$ \\
\hline $38 Q 1$ & $05 / 05 / 81$ & 31.3 & 33.6 & 64.8 & 35.8 & -0.58 & WAI & 9.8 & 15.3 & 46.8 & 17.3 \\
\hline $38 Q 1$ & $05 / 06 / 81$ & 31.0 & 33.4 & 63.9 & 35.6 & +0.06 & WAI & 9.5 & 15.1 & 45.9 & 17.1 \\
\hline $38 Q 2$ & $05 / 06 / 81$ & 31.3 & 33.6 & 63.0 & 35.8 & & WAI & 9.8 & 15.3 & 45.0 & 17.3 \\
\hline $38 Q 1$ & $05 / 07 / 81$ & 30.9 & 33.3 & 64.5 & 35.5 & +0.15 & WAI & 9.4 & 15.0 & 46.5 & 17.0 \\
\hline
\end{tabular}

dNa dNC dNc' dNd

$\begin{array}{llll}2.9 & 3.4 & 2.5 & 3.5\end{array}$

$\begin{array}{llll}2.1 & 2.6 & 4.2 & 2.9\end{array}$

$\begin{array}{lllll}2.3 & 2.5 & 5.0 & 2.9\end{array}$

$\begin{array}{llll}2.3 & 2.6 & 4.4 & 2.6\end{array}$

$\begin{array}{llll}3.3 & 3.4 & 4.6 & 3.8\end{array}$

BDR

$\begin{array}{lllll}\text { BDR } & 10.9 & 15.3 & 88.7 & 16.3\end{array}$

$\begin{array}{lllll}\text { BDR } 12.1 & 16.5 & 87.5 & 17.6\end{array}$

dNa dNe dNc' dNd

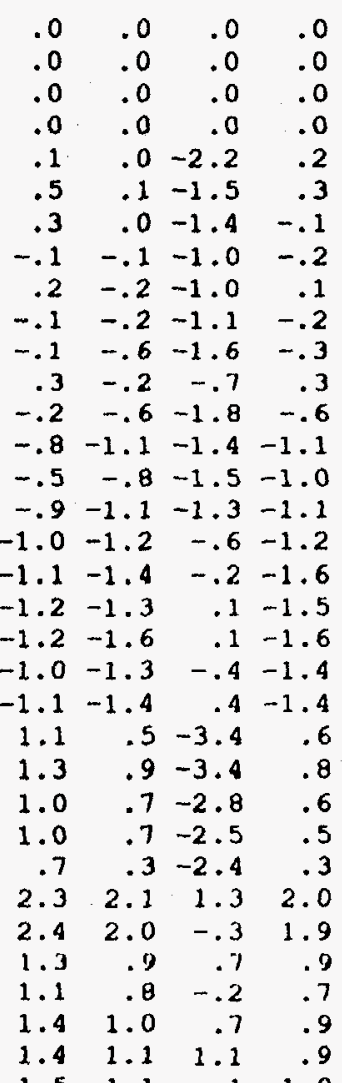

dNad dNed

dNad dNed

$-.6-.1$

$\begin{array}{rr}-.8 & -.3 \\ -.6 & -.4\end{array}$

$-.3 \quad .0$

$-.5 \quad-.4$

$\begin{array}{rr}.0 & .0 \\ .0 & .0 \\ .0 & .0 \\ .0 & .0 \\ -.1 & -.2 \\ .2 & -.2 \\ .4 & .1 \\ .1 & .1 \\ .1 & -.3 \\ .1 & .0 \\ .2 & -.3 \\ .0 & -.5 \\ .4 & .0 \\ .3 & .0 \\ .5 & .2 \\ .2 & .0 \\ .2 & .0 \\ .5 & .2 \\ .3 & .2 \\ .4 & .0 \\ .4 & .1 \\ .3 & .0 \\ .5 & -.1 \\ .5 & .1 \\ .4 & .1 \\ .5 & .2 \\ .4 & .0 \\ .3 & .1 \\ .5 & .1 \\ .4 & .0 \\ .4 & .1 \\ .5 & .1 \\ .5 & .2 \\ .5 & .1\end{array}$


Dobson Spectrophotometer No. 38

\begin{tabular}{|c|c|c|c|c|c|c|c|c|c|c|c|c|c|c|c|c|c|}
\hline LAMP & DATE & Ra & $\mathrm{RC}$ & Rc' & Rd & $\mathrm{Hg}$ & STN & $\mathrm{Na}$ & $\mathrm{Nc}$ & $N c^{\circ}$ & Nd & $\mathrm{dNa}$ & $\mathrm{dNc}$ & $\mathrm{dNc} \mathrm{c}^{\prime}$ & dNd & dNad & $\mathrm{dNC}$ \\
\hline 3801 & $07 / 28 / 83$ & 31.8 & 34.3 & 72.5 & 36.7 & +0.14 & WA I & 10.3 & 16.0 & 54.4 & 18.2 & .6 & .1 & -7.8 & -.2 & .8 & .3 \\
\hline $38 Q 1$ & $08 / 30 / 83$ & 31.7 & 34.2 & 72.9 & 36.5 & +0.11 & WAI & 10.2 & 15.9 & 54.8 & 18.0 & .7 & .2 & -8.2 & .0 & .7 & .2 \\
\hline 3801 & $09 / 29 / 83$ & 31.8 & 34.3 & 74.6 & 36.5 & +0.02 & WAI & 10.3 & 16.0 & 56.5 & 18.0 & .6 & .1 & -9.9 & .0 & .6 & .1 \\
\hline 3801 & $10 / 31 / 83$ & 31.8 & 34.5 & 74.4 & 36.7 & +0.11 & WAI & 10.3 & 16.2 & 56.3 & 18.2 & .6 & -.1 & -9.7 & -.2 & .8 & .1 \\
\hline 3801 & $11 / 28 / 83$ & 31.9 & 34.3 & 74.1 & 36.6 & -0.05 & WAI & 10.4 & 16.0 & 56.0 & 18.1 & .5 & .1 & -9.4 & -.1 & .6 & .2 \\
\hline $38 Q 1$ & $12 / 30 / 83$ & 32.0 & 34.5 & 63.3 & 36.9 & +0.15 & WAI & 10.5 & 16.2 & 45.3 & 18.4 & .4 & -.1 & 1.3 & -.4 & .8 & .3 \\
\hline $38 Q 1$ & $01 / 30 / 84$ & 32.1 & 34.5 & 63.5 & 37.0 & +0.00 & WAI & 10.6 & 16.2 & 45.5 & 18.5 & .3 & -.1 & 1.1 & -.5 & .8 & .4 \\
\hline 3801 & $02 / 28 / 84$ & 31.8 & 34.4 & 63.3 & 36.6 & -0.02 & WAI & 10.3 & 16.1 & 45.3 & 18.1 & .6 & .0 & 1.3 & -.1 & .7 & .1 \\
\hline 3801 & $03 / 28 / 84$ & 31.8 & 34.5 & 63.3 & 36.7 & -0.16 & WAI & 10.3 & 16.2 & 45.3 & 18.2 & .6 & -.1 & 1.3 & -.2 & .8 & .1 \\
\hline $38 Q 1$ & $04 / 25 / 84$ & 32.2 & 34.7 & $63.6:$ & 37.0 & -0.03 & WAI & 10.7 & 16.4 & 45.6 & 18.5 & .2 & -.3 & 1.0 & -.5 & .7 & .2 \\
\hline $38 Q 1$ & $05 / 07 / 84$ & 31.7 & 34.3 & 59.0 & 36.7 & -0.31 & BDR & 10.2 & 16.0 & 41.0 & 18.2 & .7 & .1 & 5.6 & -.2 & .9 & .3 \\
\hline $38 \mathrm{Q2}$ & $05 / 07 / 84$ & 32.2 & 34.7 & 57.0 & 37.3 & & BDR & 10.7 & 16.4 & 39.0 & 18.8 & .5 & .0 & 7.1 & -.6 & 1.1 & .6 \\
\hline $38 Q 1$ & $04 / 15 / 85$ & 25.8 & 28.0 & 37.2 & 29.8 & -0.09 & BDR & 4.1 & 9.5 & 19.0 & 11.0 & 6.8 & 6.6 & 27.6 & 7.0 & -.2 & -.4 \\
\hline $\begin{array}{l}3802 \\
3803\end{array}$ & $\begin{array}{l}04 / 15 / 85 \\
04 / 15 / 85\end{array}$ & $\begin{array}{l}26.2 \\
25.7\end{array}$ & $\begin{array}{l}28.2 \\
27.6\end{array}$ & $\begin{array}{l}36.6 \\
38.3\end{array}$ & $\begin{array}{l}30.3 \\
29.7\end{array}$ & & $\begin{array}{l}\text { BDR } \\
\text { BDR }\end{array}$ & $\begin{array}{l}4.5 \\
4.0\end{array}$ & $\begin{array}{l}9.7 \\
9.1\end{array}$ & $\begin{array}{l}18.4 \\
20.2\end{array}$ & $\begin{array}{l}11.6 \\
10.9\end{array}$ & 6.7 & 6.7 & 27.7 & 6.6 & .1 & .1 \\
\hline 38021 & $04 / 15 / 85$ & 26.9 & 29.2 & 35.4 & 31.0 & & BDR & 5.2 & 10.7 & 17.2 & 12.3 & 7.1 & 6.9 & 28.3 & 7.1 & .0 & -.2 \\
\hline $38 U_{Q 3}$ & $04 / 15 / 85$ & 26.0 & 28.0 & 37.5 & 29.8 & & BDR & 4.3 & 9.5 & 19.3 & 11.0 & & & & & & \\
\hline $38 Q 1$ & $05 / 08 / 85$ & 25.7 & 27.8 & 36.7 & 29.7 & -0.14 & BDR & 12.0 & 16.8 & 26.7 & 18.3 & .0 & .0 & .0 & .0 & .0 & .0 \\
\hline $38 Q 2$ & $05 / 08 / 85$ & 26.0 & 28.2 & 35.7 & 30.2 & & BDR & 12.3 & 17.2 & 25.6 & 18.8 & .0 & .0 & .0 & .0 & .0 & .0 \\
\hline 3803 & $05 / 08 / 85$ & 25.4 & 27.7 & 38.0 & 29.5 & & BDR & 11.7 & 16.7 & 28.1 & 18.0 & .0 & .0 & .0 & .0 & .0 & .0 \\
\hline 38001 & $05 / 08 / 85$ & 27.2 & 29.2 & 35.4 & 31.2 & & BDR & 13.7 & 18.3 & 25.3 & 20.0 & .0 & .0 & .0 & .0 & .0 & .0 \\
\hline 380Q3 & $05 / 08 / 85$ & 26.0 & 28.0 & 38.3 & 30.0 & & BDR & 12.3 & 17.0 & 28.5 & 18.6 & .0 & .0 & .0 & .0 & .0 & .0 \\
\hline 38003 & $05 / 28 / 85$ & & & & & +1.14 & WAI & & & & & & & & & & \\
\hline $38 \cup Q 3$ & $05 / 28 / 85$ & & & & & +1.08 & WAI & & & & & & & & & & \\
\hline 38003 & $05 / 28 / 85$ & & & & & +1.31 & WAI & & & & & & & & & & \\
\hline 38Q1 & $05 / 29 / 85$ & 25.9 & 27.9 & 36.3 & 29.9 & +0.09 & WAI & 12.2 & 16.9 & 26.2 & 18.5 & -.2 & -.1 & .5 & -.2 & .0 & $\begin{array}{r}.1 \\
-.1\end{array}$ \\
\hline $\begin{array}{l}38 Q 2 \\
3801\end{array}$ & $\begin{array}{l}05 / 29 / 85 \\
06 / 28 / 85\end{array}$ & $\begin{array}{l}26.2 \\
25.7\end{array}$ & $\begin{array}{l}28.2 \\
27.7\end{array}$ & $\begin{array}{l}34.4 \\
36.9\end{array}$ & $\begin{array}{l}30.1 \\
29.6\end{array}$ & +0.31 & $\begin{array}{l}\text { WAI } \\
\text { WAI }\end{array}$ & $\begin{array}{l}12.6 \\
12.0\end{array}$ & $\begin{array}{l}17.2 \\
16.7\end{array}$ & $\begin{array}{l}24.1 \\
26.9\end{array}$ & $\begin{array}{l}18.7 \\
18.1\end{array}$ & $\begin{array}{r}-.3 \\
.0\end{array}$ & $\begin{array}{l}.0 \\
.1\end{array}$ & $\begin{array}{l}1.5 \\
-.2\end{array}$ & $\begin{array}{l}.1 \\
.2\end{array}$ & $\begin{array}{l}-.4 \\
-.2\end{array}$ & $\begin{array}{l}-.1 \\
-.1\end{array}$ \\
\hline 3801 & $07 / 29 / 85$ & 26.0 & 28.0 & 37.4 & 30.0 & +0.25 & WAI & 12.3 & 17.0 & 27.5 & 18.6 & -.3 & -.2 & -.8 & -.3 & .0 & .1 \\
\hline 3801 & $08 / 28 / 85$ & 25.8 & 27.9 & 37.6 & 29.9 & +0.29 & WAI & 12.1 & 16.9 & 27.7 & 18.5 & -.1 & -.1 & -1.0 & -.2 & .1 & .1 \\
\hline $38 Q 1$ & $09 / 30 / 85$ & 26.0 & 28.1 & 38.1 & 30.2 & +0.10 & WAI & 12.3 & 17.1 & 28.2 & 18.8 & -.3 & -.3 & -1.5 & -.5 & .2 & .2 \\
\hline $38 Q 1$ & $10 / 29 / 85$ & 26.1 & 28.1 & 38.1 & 30.0 & +0.29 & WAI & 12.5 & 17.1 & 28.2 & 18.6 & -.5 & -.3 & -1.5 & -.3 & -.2 & .0 \\
\hline $38 Q 1$ & $12 / 02 / 85$ & 26.0 & 28.1 & 38.5 & 30.2 & +0.22 & WAI & 12.3 & 17.1 & 28.7 & 18.8 & -.3 & -.3 & -2.0 & -.5 & .2 & .2 \\
\hline 3801 & $12 / 30 / 85$ & 26.1 & 28.2 & 38.0 & 30.0 & +0.37 & WAI & 12.5 & 17.2 & 28.1 & 18.6 & -.5 & -.4 & -1.4 & -.3 & -.2 & -.1 \\
\hline 3801 & $01 / 27 / 86$ & 26.0 & 28.0 & 37.9 & 30.0 & +0.17 & WAI & 12.3 & 17.0 & 28.0 & 18.6 & -.3 & -.2 & -1.3 & -.3 & .0 & .1 \\
\hline 3801 & $02 / 28 / 86$ & 26.4 & 28.4 & 38.0 & 30.1 & +0.35 & WAI & 12.8 & 17.4 & 28.1 & 18.7 & -.8 & -.6 & -1.4 & -.4 & -.4 & -.2 \\
\hline 3801 & $03 / 28 / 86$ & 26.1 & 28.2 & 37.8 & 30.1 & +0.35 & WAI & 12.5 & 17.2 & 27.9 & 18.7 & -.5 & -.4 & -1.2 & -.4 & -.1 & .0 \\
\hline $38 Q 1$ & $04 / 28 / 86$ & 26.6 & 28.6 & 38.4 & 30.5 & +0.17 & WAI & 13.0 & 17.7 & 28.6 & 19.2 & -1.0 & -.9 & -1.9 & -.9 & -.1 & .0 \\
\hline 3801 & $05 / 28 / 86$ & 26.2 & 28.3 & 38.5 & 30.1 & +0.03 & WAI & 12.6 & 17.3 & 28.7 & 18.7 & -.6 & -.5 & -2.0 & -.4 & -.2 & -.1 \\
\hline 3801 & $06 / 27 / 86$ & 26.3 & 28.2 & 38.1 & 30.4 & +0.38 & WAI & 12.7 & 17.2 & 28.2 & 19.1 & -.7 & -.4 & -1.5 & -.8 & .1 & .4 \\
\hline 3801 & $07 / 28 / 86$ & 26.3 & 28.4 & 39.0 & 30.3 & +0.10 & WAI & 12.7 & 17.4 & 29.2 & 18.9 & -.7 & -.6 & -2.5 & -.6 & -.1 & .0 \\
\hline $38 Q 2$ & $08 / 29 / 86$ & 26.2 & 28.1 & 38.3 & 30.1 & +0.34 & WAI & 12.6 & 17.1 & 28.5 & 18.7 & -.6 & -.3 & -1.8 & -.4 & -.2 & .1 \\
\hline $38 Q 1$ & $09 / 29 / 86$ & 26.1 & 28.1 & 38.3 & 30.1 & +0.19 & WAI & 12.5 & 17.1 & 28.5 & 18.7 & -.5 & -.3 & -1.8 & -.4 & -.1 & .1 \\
\hline $38 Q 1$ & $10 / 10 / 86$ & 26.4 & 28.5 & 37.9 & 30.5 & +0.37 & WAI & 12.8 & 17.6 & 28.0 & 19.2 & -.8 & -.8 & -1.3 & -.9 & .1 & .1 \\
\hline 3802 & $10 / 10 / 86$ & 26.6 & 28.9 & 35.9 & 30.9 & & WAI & 13.0 & 18.0 & 25.8 & 19.6 & -.7 & -.8 & -.2 & -.8 & .1 & .0 \\
\hline 38R22 & $10 / 10 / 86$ & 26.8 & 28.8 & 36.3 & 30.8 & $+0.37^{\star}$ & WAI & 13.2 & 17.9 & 26.2 & 19.5 & & & & & & \\
\hline $38 R 23$ & $10 / 10 / 86$ & 26.3 & 28.5 & 36.7 & 30.5 & * & WAI & 12.7 & 17.6 & 26.7 & 19.2 & & & & & & \\
\hline
\end{tabular}


Dobson Spectrophotometer No. 38

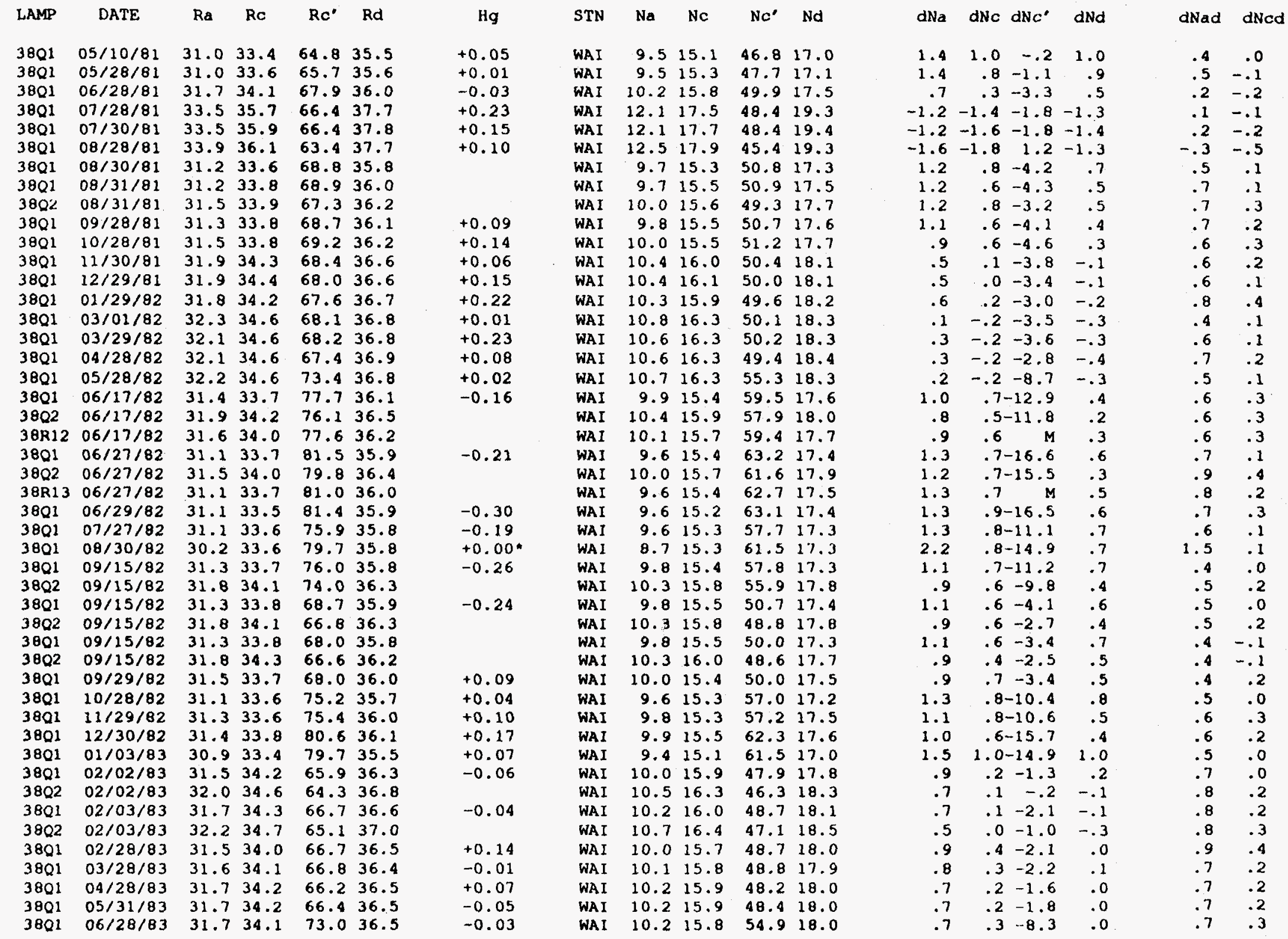


Dobson Spectrophotometer No. 38

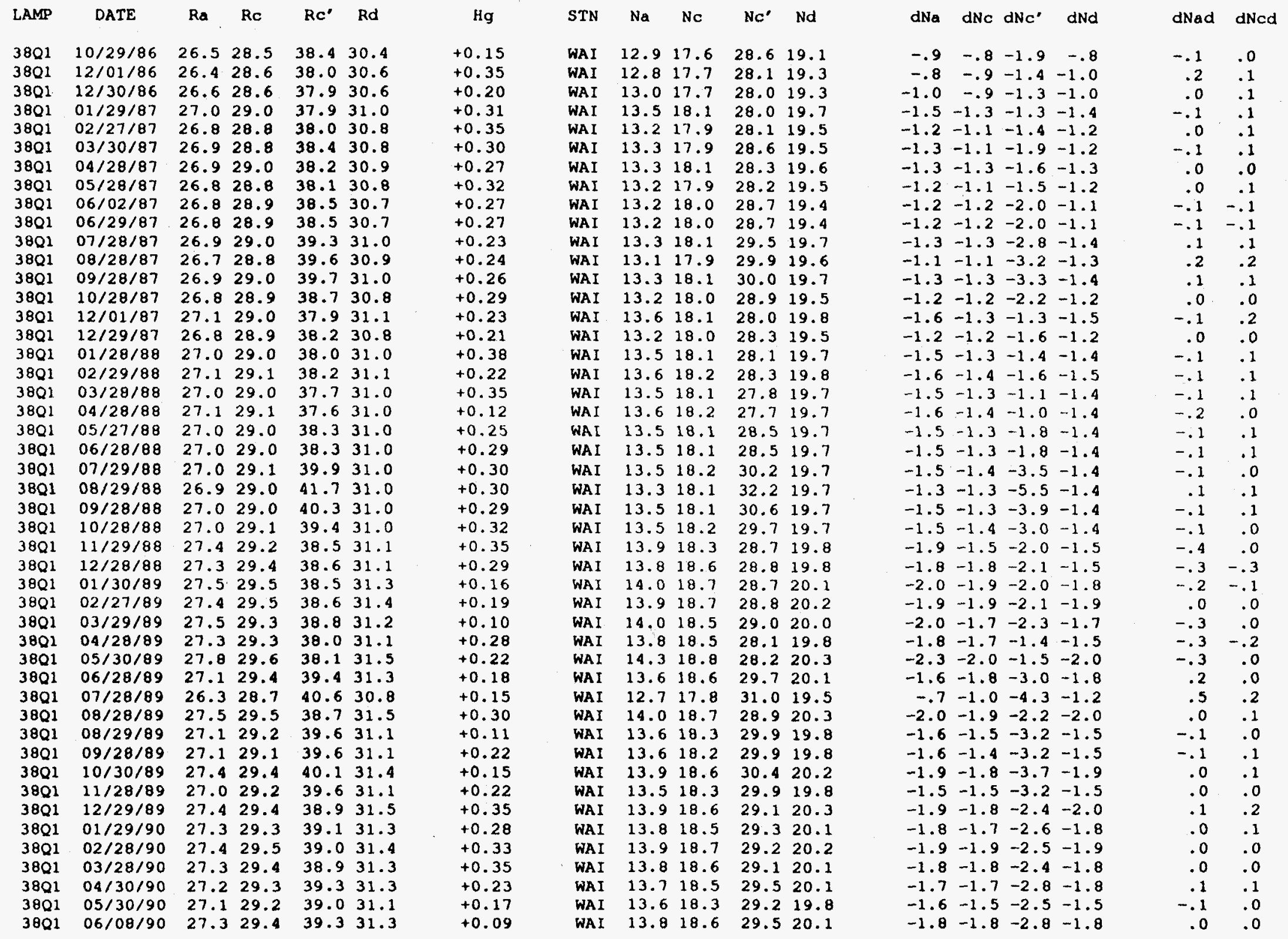


Dobson Spectrophotometer No. 38

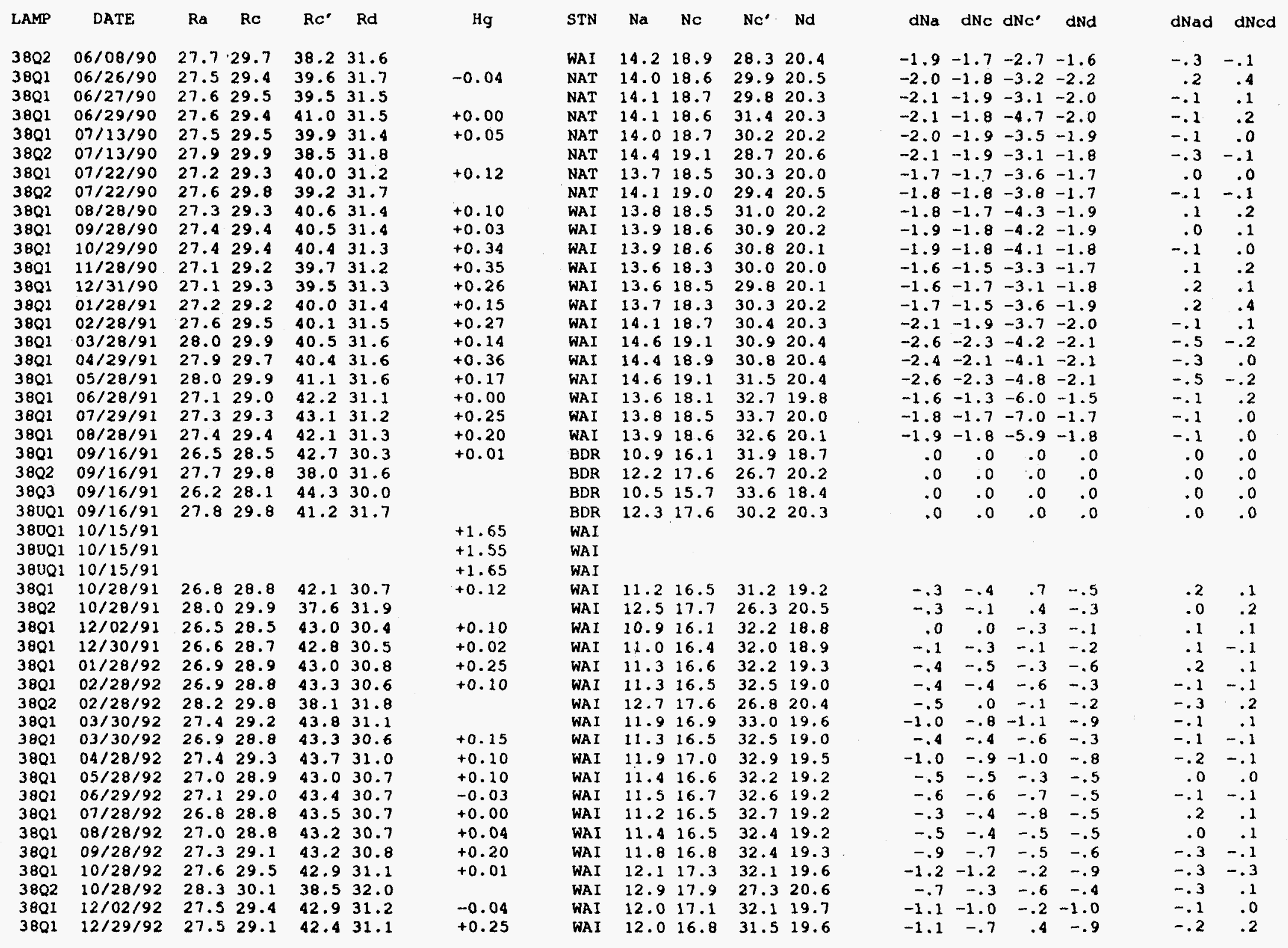


Dobson Spectrophotometer No. 38

\begin{tabular}{|c|c|c|c|c|c|c|c|c|c|c|c|c|c|c|c|c|c|}
\hline LAMP & DATE & $\mathbf{R a}$ & Re & $\mathbf{R} \mathbf{c}^{\prime}$ & $\mathbf{R d}$ & $\mathrm{Hg}$ & STN & Na & $\mathrm{Nc}$ & $N c^{\prime}$ & Nd & $\mathrm{dNa}$ & dNc & $\mathrm{dNc} \mathrm{c}^{\prime}$ & $\mathrm{dNd}$ & dNad & dNcd \\
\hline 3801 & $01 / 28 / 93$ & 27.8 & 29.6 & 42.7 & 31.4 & +0.30 & WAI & 12.3 & 17.4 & 31.9 & 20.0 & -1.4 & -1.3 & .0 & -1.3 & -.1 & .0 \\
\hline $38 Q 1$ & $03 / 01 / 93$ & 27.8 & 29.7 & 42.9 & 31.5 & +0.20 & WAI & 12.3 & 17.5 & 32.1 & 20.1 & -1.4 & -1.4 & -.2 & -1.4 & .0 & .0 \\
\hline 3802 & $03 / 01 / 93$ & 28.9 & 30.9 & 38.7 & 32.6 & & WAI & 13.5 & 18.8 & 27.5 & 21.3 & -1.3 & -1.2 & -.8 & -1.1 & -.2 & -.1 \\
\hline $38 Q 1$ & $03 / 29 / 93$ & 27.6 & 29.6 & 42.3 & 31.3 & -0.17 & WAI & 12.1 & 17.4 & 31.4 & 19.8 & -1.2 & -1.3 & .5 & -1.1 & -.1 & -.2 \\
\hline 3801 & $04 / 28 / 93$ & 27.7 & 29.9 & 42.9 & 31.5 & +0.25 & WAI & 12.2 & 17.7 & 32.1 & 20.1 & -1.3 & -1.6 & -.2 & -1.4 & .1 & -.2 \\
\hline $38 Q 1$ & $05 / 28 / 93$ & 28.2 & 30.0 & 43.3 & 31.5 & -0.10 & WAI & 12.7 & 17.8 & 32.7 & 20.1 & -1.8 & -1.7 & -.8 & -1.4 & -.4 & -.3 \\
\hline 3801 & $06 / 28 / 93$ & 27.9 & 29.8 & 43.4 & 31.6 & +0.05 & WAI & 12.4 & 17.6 & 32.6 & 20.2 & -1.5 & -1.5 & -.7 & -1.5 & .0 & .0 \\
\hline 3801 & $07 / 29 / 93$ & 28.0 & 29.9 & 43.0 & 31.6 & -0.03 & WAI & 12.5 & 17.7 & 32.2 & 20.2 & -1.6 & -1.6 & -.3 & -1.5 & -.1 & -.1 \\
\hline $38 Q 2$ & $07 / 29 / 93$ & 29.0 & 31.0 & 38.9 & 32.6 & & WAI & 13.6 & 18.9 & 27.7 & 21.3 & -1.4 & -1.3 & -1.0 & -1.1 & -.3 & -.2 \\
\hline 3801 & $08 / 30 / 93$ & 28.1 & 30.1 & 42.0 & 31.9 & +0.14 & WAI & 12.6 & 17.9 & 31.1 & 20.5 & -1.7 & -1.8 & .8 & -1.8 & .1 & .0 \\
\hline $38 Q 1$ & $09 / 30 / 93$ & 28.5 & 30.4 & 42.5 & 32.0 & +0.10 & WAI & 13.1 & 18.3 & 31.6 & 20.6 & -2.2 & -2.2 & .3 & -1.9 & -.3 & -.3 \\
\hline $38 Q 1$ & $10 / 19 / 93$ & 28.4 & 30.4 & 41.2 & 32.0 & +0.22 & WAI & 13.0 & 18.3 & 30.2 & 20.6 & -2.1 & -2.2 & 1.7 & -1.9 & -.2 & -.3 \\
\hline 3801 & $10 / 19 / 93$ & 28.0 & 30.3 & 40.6 & 31.9 & & WAI & 12.5 & 18.2 & 29.6 & 20.5 & -1.6 & -2.1 & 2.3 & -1.8 & .2 & -.3 \\
\hline $38 Q 1$ & $10 / 29 / 93$ & 27.9 & 30.0 & 40.5 & 31.7 & -0.02 & WAI & 12.4 & 17.8 & 29.4 & 20.3 & -1.5 & -1.7 & 2.5 & -1.6 & .1 & -.1 \\
\hline $38 Q 1$ & $11 / 30 / 93$ & 28.4 & 30.5 & 41.0 & 32.3 & -0.07 & WAI & 13.0 & 18.4 & 30.0 & 21.0 & -2.1 & -2.3 & 1.9 & -2.3 & .2 & .0 \\
\hline 3801 & $12 / 30 / 93$ & 28.1 & 30.3 & 41.4 & 32.1 & +0.57 & WAI & 12.6 & 18.2 & 30.4 & 20.7 & -1.7 & -2.1 & 1.5 & -2.0 & .3 & -.1 \\
\hline $38 Q 1$ & $12 / 30 / 93$ & 28.2 & 30.3 & 41.4 & 32.2 & & WAI & 12.7 & 18.2 & 30.4 & 20.8 & -1.8 & -2.1 & 1.5 & -2.1 & .3 & .0 \\
\hline 3801 & $01 / 03 / 94$ & & & & & +0.06 & WAI & & & & & & & & & & \\
\hline $38 Q 1$ & $01 / 03 / 94$ & & & & & +0.07 & WAI & & & & & & & & & & \\
\hline 3801 & $01 / 04 / 94$ & & & & & -0.02 & WAI & & & & & & & & & & \\
\hline $38 Q 1$ & $01 / 05 / 94$ & & & & & -0.04 & WAI & & & & & & & & & & \\
\hline 3801 & $01 / 06 / 94$ & & & & & +0.08 & WAI & & & & & & & & & & \\
\hline 3801 & $01 / 31 / 94$ & 28.1 & 30.3 & 41.5 & 32.0 & +0.11 & WAI & 12.6 & 18.2 & 30.5 & 20.6 & -1.7 & -2.1 & 1.4 & -1.9 & .2 & -.2 \\
\hline 3802 & $01 / 31 / 94$ & 29.0 & 31.1 & 37.3 & 33.0 & & WAI & 13.6 & 19.0 & 25.9 & 21.7 & -1.4 & -1.4 & .8 & -1.5 & .1 & .1 \\
\hline $38 Q 1$ & $02 / 02 / 94$ & 28.3 & 30.4 & 41.1 & 32.2 & & WAI & 12.9 & 18.3 & 30.1 & 20.8 & -2.0 & -2.2 & 1.8 & -2.1 & .1 & -.1 \\
\hline 3801 & $02 / 28 / 94$ & 27.0 & 29.2 & 43.1 & 31.2 & +0.23 & WAI & 11.4 & 16.9 & 32.3 & 19.7 & -.5 & -.8 & -.4 & -1.0 & .5 & .2 \\
\hline 3801 & $03 / 31 / 94$ & 26.9 & 29.0 & 43.4 & 30.9 & +0.25 & WAI & 11.3 & 16.7 & 32.6 & 19.4 & -.4 & -.6 & -.7 & -.7 & .3 & .1 \\
\hline 3801 & $04 / 05 / 94$ & 26.8 & 28.8 & 43.7 & 30.7 & & WAI & 11.2 & 16.5 & 32.9 & 19.2 & -.3 & -.4 & -1.0 & -.5 & .2 & .1 \\
\hline $38 Q 2$ & $04 / 05 / 94$ & 27.7 & 29.8 & 40.0 & 31.7 & & WAI & 12.2 & 17.6 & 28.9 & 20.3 & .0 & .0 & -2.2 & -.1 & .1 & .1 \\
\hline 38R51 & $04 / 05 / 94$ & 26.7 & 28.8 & 43.8 & 30.6 & & WAI & 11.1 & 16.5 & 33.0 & 19.0 & & & & & & \\
\hline $38 R 52$ & $04 / 05 / 94$ & 26.7 & 28.8 & 44.3 & 30.7 & & WAI & 11.1 & 16.5 & 33.6 & 19.2 & & & & & & \\
\hline 3801 & $04 / 06 / 94$ & 26.9 & 29.0 & 42.8 & 30.9 & & WAI & 11.3 & 16.7 & 32.0 & 19.4 & -.4 & -.6 & -.1 & -.7 & .3 & .1 \\
\hline $38 Q 2$ & $04 / 06 / 94$ & 27.5 & 29.7 & 39.9 & 31.6 & & WAI & 12.0 & 17.5 & 28.8 & 20.2 & .2 & .1 & -2.1 & .0 & .2 & .1 \\
\hline 38R51 & $04 / 06 / 94$ & 26.6 & 28.7 & 43.6 & 30.6 & & WAI & 11.0 & 16.4 & 32.8 & 19.0 & & & & & & \\
\hline 38R52 & $04 / 06 / 94$ & 26.6 & 28.7 & 44.1 & 30.6 & & WAI & 11.0 & 16.4 & 33.4 & 19.0 & & & & & & \\
\hline 3801 & $04 / 07 / 94$ & 26.8 & 28.9 & 41.7 & 30.8 & * & WAI & 11.2 & 16.6 & 30.8 & 19.3 & -.3 & -.5 & 1.1 & -.6 & .3 & .1 \\
\hline $38 Q 1$ & $04 / 07 / 94$ & 26.8 & 28.9 & 43.2 & 30.8 & & WAI & 11.2 & 16.6 & 32.4 & 19.3 & -.3 & -.5 & -.5 & -.6 & .3 & .1 \\
\hline $38 Q 1$ & $04 / 07 / 94$ & 26.8 & 28.9 & 43.2 & 30.8 & & WAI & 11.2 & 16.6 & 32.4 & 19.3 & -.3 & -.5 & -.5 & -.6 & .3 & .1 \\
\hline $38 Q 1$ & $04 / 11 / 94$ & 26.8 & 28.9 & 43.1 & 30.7 & & WAI & 11.2 & 16.6 & 32.3 & 19.2 & -.3 & -.5 & -.4 & -.5 & .2 & .0 \\
\hline $38 Q 1$ & $04 / 29 / 94$ & 26.6 & 28.7 & 44.0 & 30.6 & +0.07 & WAI & 11.0 & 16.4 & 33.3 & 19.0 & -.1 & -.3 & -1.4 & -.3 & .2 & .0 \\
\hline 38Q1 & $05 / 31 / 94$ & 26.7 & 28.7 & 44.1 & 30.6 & +0.18 & WAI & 11.1 & 16.4 & 33.4 & 19.0 & -.2 & -.3 & -1.5 & -.3 & .1 & .0 \\
\hline 3801 & $07 / 05 / 94$ & 26.6 & 28.7 & 44.0 & 30.6 & +0.11 & WAI & 11.0 & 16.4 & 33.3 & 19.0 & -.1 & -.3 & -1.4 & -.3 & .2 & .0 \\
\hline 3802 & $07 / 05 / 94$ & 27.4 & 29.4 & 41.2 & 31.4 & +0.17 & WAI & 11.9 & 17.1 & 30.2 & 20.0 & .3 & .5 & -3.5 & .2 & .1 & .3 \\
\hline $38 Q 1$ & $07 / 15 / 94$ & 26.8 & 28.8 & 44.5 & 30.6 & +0.06 & WAI & 11.2 & 16.5 & 33.8 & 19.0 & -.3 & -.4 & -1.9 & -.3 & .0 & -.1 \\
\hline 3801 & $08 / 01 / 94$ & 26.6 & 28.7 & 44.2 & 30.6 & +0.16 & WAI & 11.0 & 16.4 & 33.5 & 19.0 & -.1 & -.3 & -1.6 & -.3 & .2 & .0 \\
\hline 3801 & $09 / 01 / 94$ & 26.7 & 28.7 & 43.8 & 30.6 & -0.04 & WAI & 11.1 & 16.4 & 33.0 & 19.0 & -.2 & -.3 & $-1 \cdot 1$ & -.3 & .1 & .0 \\
\hline $38 Q 1$ & $10 / 03 / 94$ & 27.0 & 28.9 & 42.3 & 30.9 & +0.27 & WAI & 11.4 & 16.6 & 31.4 & 19.4 & -.5 & -.5 & .5 & -.7 & .2 & .2 \\
\hline
\end{tabular}


Dobson Spectrophotometer No. 38

\begin{tabular}{|c|c|c|c|c|c|c|c|c|c|c|c|}
\hline LAMP & DATE & $\mathrm{Ra}$ & Rc & $\mathrm{Rc}^{*}$ & $\mathbf{R d}$ & $\mathrm{Hg}$ & STN & $\mathrm{Na}$ & $\mathrm{Nc}$ & $\mathrm{Nc}^{\prime}$ & $\mathrm{Nd}$ \\
\hline $38 Q 1$ & $11 / 01 / 94$ & 26.9 & 28.9 & 43.9 & 30.9 & -0.02 & WAI & 11.3 & 16.6 & 33.2 & 19.4 \\
\hline $38 Q 1$ & $12 / 01 / 94$ & 27.1 & 29.1 & 43.7 & 31.0 & +0.21 & WAI & 11.5 & 16.8 & 32.9 & 19.5 \\
\hline & $12 / 01 / 94$ & 27.8 & 29.8 & 92.0 & 31.7 & & WAI & 12.3 & 17.6 & 30.0 & 20.3 \\
\hline 3801 & $01 / 03 / 95$ & 27.1 & 29.3 & 43.7 & 31.2 & +0.22 & WA I & 11.5 & 17.0 & 32.9 & 19.7 \\
\hline 3801 & $02 / 01 / 95$ & 27.0 & 29.1 & 43.5 & 31.0 & +0.04 & WAI & 11.4 & 16.8 & 32.7 & 19.5 \\
\hline $38 Q 1$ & $02 / 17 / 95$ & 27.0 & 29.2 & 43.0 & 31.1 & & WAI & 11.4 & 16.9 & 32.2 & 19.6 \\
\hline 3801 & $03 / 01 / 95$ & 26.9 & 29.0 & 42.9 & 30.9 & +0.13 & WAI & 11.3 & 16.7 & 32.1 & 19.4 \\
\hline 3802 & $03 / 01 / 95$ & 27.5 & 29.8 & 40.0 & 31.6 & & WAI & 12.0 & 17.6 & 28.9 & 20.2 \\
\hline 3801 & $03 / 07 / 95$ & 27.0 & 29.0 & 42.9 & 30.9 & +0.05 & WAI & 11.4 & 16.7 & 32.1 & 19.4 \\
\hline $38 Q 1$ & $04 / 03 / 95$ & 27.2 & 29.3 & 43.0 & 31.2 & +0.19 & WAI & 11.6 & 17.0 & 32.2 & 19.7 \\
\hline 3801 & $04 / 04 / 95$ & 27.2 & 29.3 & 43.2 & 31.2 & & WAI & 11.6 & 17.0 & 32.4 & 19.7 \\
\hline 3801 & $04 / 24 / 95$ & 27.2 & 29.3 & 43.5 & 31.2 & -1.61 & BDR & 11.6 & 17.0 & 32.7 & 19.7 \\
\hline $38 Q 2$ & $04 / 24 / 95$ & 27.7 & 29.8 & 42.2 & 31.6 & & BDR & 12.2 & 17.6 & 31.3 & 20.2 \\
\hline 3802 & $04 / 25 / 95$ & & & & & +0.06 & BDR & & & & \\
\hline 3821 & $04 / 27 / 95$ & 26.9 & 28.9 & 43.7 & 30.8 & +0.04 & BDR & 10.2 & 15.6 & 32.0 & 17.9 \\
\hline $\begin{array}{l}38 Q 2 \\
38 Q 3\end{array}$ & $\begin{array}{l}04 / 27 / 95 \\
04 / 27 / 95\end{array}$ & $\begin{array}{l}27.5 \\
26.7\end{array}$ & $\begin{array}{l}29.4 \\
28.6\end{array}$ & $\begin{array}{l}42.0 \\
44.9\end{array}$ & $\begin{array}{l}31.4 \\
30.6\end{array}$ & & $\begin{array}{l}\text { BDR } \\
\text { BDR }\end{array}$ & $\begin{array}{r}10.8 \\
9.9\end{array}$ & $\begin{array}{l}16.2 \\
15.3\end{array}$ & $\begin{array}{l}30.1 \\
33.3\end{array}$ & $\begin{array}{l}18.6 \\
17.7\end{array}$ \\
\hline $380 Q 1$ & $04 / 27 / 95$ & 28.3 & 30.3 & 41.3 & 32.3 & & $B D R$ & 11.7 & 17.2 & 29.4 & 19.6 \\
\hline $380 Q 2$ & $04 / 27 / 95$ & 27.9 & 29.8 & 41.4 & 31.8 & & BDR & 11.3 & 16.6 & 29.5 & 19.0 \\
\hline $380 Q 7$ & $04 / 27 / 95$ & 27.2 & 28.8 & 44.1 & 30.9 & & BDR & 10.5 & 15.5 & 32.4 & 18.0 \\
\hline $38 \cup Q 8$ & $04 / 27 / 95$ & 27.0 & 28.8 & 44.2 & 30.8 & & BOR & 10.3 & 15.5 & 32.5 & 17.9 \\
\hline 3801 & $05 / 16 / 95$ & 26.6 & 28.7 & 43.2 & 30.6 & & WAI & 9.8 & 15.4 & 31.4 & 17.7 \\
\hline $38 Q 1$ & $05 / 22 / 95$ & 26.7 & 28.8 & 44.1 & 30.5 & -0.04 & WAI & 9.9 & 15.5 & 32.4 & 17.5 \\
\hline $38 Q 2$ & $05 / 22 / 95$ & 27.1 & 29.1 & 42.3 & 30.9 & & WAI & 10.4 & 15.8 & 30.4 & $18: 0$ \\
\hline $38 Q 1$ & $05 / 30 / 95$ & 26.3 & 28.4 & 43.4 & 30.3 & +0.00 & WAI & 9.5 & 15.1 & 31.6 & 17.3 \\
\hline $38 Q 1$ & $06 / 01 / 95$ & 26.4 & 28.5 & 43.8 & 30.5 & +0.00 & WAI & 9.6 & 15.2 & 32.1 & 17.5 \\
\hline $38 Q 2$ & $06 / 01 / 95$ & 26.9 & 29.0 & 42.0 & 30.9 & & WAI & 10.2 & 15.7 & 30.1 & 18.0 \\
\hline $38 Q 1$ & $06 / 23 / 95$ & 26.6 & 28.7 & 42.8 & 30.6 & +0.05 & WAI & 9.8 & 15.4 & 31.0 & 17.7 \\
\hline $38 Q 1$ & $06 / 30 / 95$ & 26.6 & 28.7 & 43.1 & 30.5 & +0.00 & WAI & 9.8 & 15.4 & 31.3 & 17.5 \\
\hline 3801 & $07 / 12 / 95$ & 26.6 & 28.7 & 42.5 & 30.6 & +0.01 & WAI & 9.8 & 15.4 & 30.7 & 17.7 \\
\hline 3801 & $07 / 31 / 95$ & 26.9 & 28.8 & 42.5 & 30.6 & -0.13 & WAI & 10.2 & 15.5 & 30.7 & 17.7 \\
\hline $38 Q 1$ & $08 / 01 / 95$ & 26.5 & 28.6 & 42.4 & 30.5 & -0.11 & WAI & $\begin{array}{r}9.7 \\
9.7\end{array}$ & 15.3 & 30.6 & 17.5 \\
\hline
\end{tabular}

$\begin{array}{rrrrrr}\text { dNa } & \text { dNc } & d N c^{\prime} & d N d & d N a d & d N c d \\ -.4 & -.5 & -1.3 & -.7 & .3 & .2 \\ -.6 & -.7 & -1.0 & -.8 & .2 & .1 \\ -.1 & .0 & -3.3 & -.1 & .0 & .1 \\ -.6 & -.9 & -1.0 & -1.0 & .4 & .1 \\ -.5 & -.7 & -.8 & -.8 & .3 & .1 \\ -.5 & -.8 & -.3 & -.9 & .4 & .1 \\ -.4 & -.6 & -. .2 & -.7 & .3 & .1 \\ .2 & .0 & -2.2 & .0 & .2 & .0 \\ -.5 & -.6 & -.2 & -.7 & .2 & .1 \\ -.7 & -.9 & -.3 & -1.0 & .3 & .1 \\ -.7 & -.9 & -.5 & -1.0 & .3 & .1 \\ -.7 & -.9 & -.8 & -1.0 & .3 & .1 \\ .0 & .0 & -4.6 & .0 & .0 & .0 \\ & & & & & \\ .0 & .0 & .0 & .0 & .0 & .0 \\ .0 & .0 & .0 & .0 & .0 & .0 \\ .0 & .0 & .0 & .0 & .0 & .0 \\ .0 & .0 & .0 & .0 & .0 & .0 \\ .0 & .0 & .0 & .0 & .0 & .0 \\ .0 & .0 & .0 & .0 & .0 & .0 \\ .0 & .0 & .0 & .0 & .0 & .0 \\ .4 & .2 & .6 & .2 & .2 & .0 \\ .3 & .1 & -.4 & .4 & -.1 & -.3 \\ .4 & .4 & -.3 & .6 & -.2 & -.2 \\ .7 & .5 & .4 & .6 & .1 & -.1 \\ .6 & .4 & -.1 & .4 & .2 & .0 \\ .6 & .5 & .0 & .6 & .0 & -.1 \\ .4 & .2 & 1.0 & .2 & .2 & .0 \\ .4 & .2 & .7 & .4 & .0 & -.2 \\ .4 & .2 & 1.3 & .2 & .2 & .0 \\ .0 & .1 & 1.3 & .2 & -.2 & -.1 \\ .5 & .3 & 1.4 & .4 & .1 & -.1 \\ .0 & -.1 & 1.4 & -.1 & .1 & .0 \\ & & & & & \end{array}$

Dobson Spectrophotometor No. 86

\begin{tabular}{|c|c|c|c|c|c|c|c|c|c|c|c|}
\hline LAMP & DATE & Ra & Ro & $R c^{\prime}$ & Rd & $\mathrm{Hg}$ & STN & $\mathrm{Na}$ & No & $\mathrm{No}^{\circ}$ & Nd \\
\hline 8601 & $05 / 26 / 83$ & 42.6 & 40.4 & 67.1 & 38.7 & -0.07 & $B D R$ & 11.8 & 16.5 & 44.6 & 18.4 \\
\hline 8602 & $05 / 26 / 83$ & 42.7 & 40.4 & 67.2 & 38.5 & & BDR & 11.9 & 16.5 & 44.7 & 18.2 \\
\hline 8603 & $05 / 26 / 83$ & 42.8 & 40.6 & 66.4 & 38.6 & & BDR & 12.0 & 16.7 & $43 / 9$ & 18.3 \\
\hline $860 Q 1$ & $05 / 26 / 83$ & 44.2 & 42.8 & 65.2 & 40.2 & & $B D R$ & 13.6 & 18.0 & 42.7 & 20.1 \\
\hline 86UQI & $05 / 26 / 83$ & .43 .7 & 41.3 & 64.8 & 39.7 & & $\mathrm{BDR}$ & 13.0 & 17.5 & 42.2 & 19.5 \\
\hline $86 \cup Q 3$ & $05 / 26 / 83$ & 42.8 & 40.7 & 66.4 & 38.8 & & $B D R$ & 12.0 & 16.8 & 43.9 & 18.5 \\
\hline $86 Q 1$ & $04 / 27 / 84$ & 43.7 & 41.6 & 63.6 & 39.6 & +1.50 & WAI & 13.0 & 17.8 & 41.0 & 19.4 \\
\hline 8601 & $04 / 27 / 84$ & & & & & +1.30 & WAI & & & & \\
\hline $86 Q 1$ & $04 / 27 / 84$ & & & & & +1.20 & WAI & & & & \\
\hline
\end{tabular}

dNa dNa dNa' dNd

$\begin{array}{llll}.0 & .0 & .0 & .0 \\ .0 & .0 & .0 & .0\end{array}$

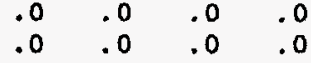

$\begin{array}{llll}.0 & .0 & .0 & .0\end{array}$

$\begin{array}{rrrr}.0 & .0 & .0 & .0 \\ -1.2 & -1.3 & 3.6 & -1.0\end{array}$
dNad dNad

$.0 \quad .0$

$\begin{array}{ll}.0 & .0 \\ .0 & .0 \\ .0 & .0\end{array}$

.0 .0 
Dobson Spectrophotometar No. 86

\begin{tabular}{|c|c|c|c|c|c|c|c|c|c|c|c|c|c|c|c|c|c|}
\hline LAMP & DATE & Ra & Rs & $R c^{\prime}$ & $\mathbf{R d}$ & $\mathrm{Hg}$ & STN & Na & Nc & $\mathrm{Nc}^{\prime}$ & Nd & dNa & $\mathrm{dNc}$ & dNc. & dNd & dNad & dNed \\
\hline $\begin{array}{l}86 Q 1 \\
8602 \\
8602\end{array}$ & $\begin{array}{l}04 / 27 / 84 \\
04 / 27 / 84 \\
04 / 30 / 84\end{array}$ & 43.8 & 41.5 & 63.3 & 39.6 & $\begin{array}{l}+1.50 \\
+1.45\end{array}$ & $\begin{array}{l}\text { WAI } \\
\text { WAI } \\
\text { WAI }\end{array}$ & 13.1 & 17.7 & 40.7 & 19.4 & -1.2 & -1.2 & 4.0 & -1.2 & .0 & .0 \\
\hline $\begin{array}{l}8601 \\
8601\end{array}$ & $\begin{array}{l}05 / 29 / 84 \\
06 / 28 / 84\end{array}$ & $\begin{array}{l}44.5 \\
44.4\end{array}$ & $\begin{array}{l}42.0 \\
41.0\end{array}$ & $\begin{array}{l}62.4 \\
63.5\end{array}$ & $\begin{array}{l}40.4 \\
40.2\end{array}$ & $\begin{array}{l}+0.04 \\
-0.09\end{array}$ & $\begin{array}{l}\text { WAI } \\
\text { WAI }\end{array}$ & $\begin{array}{l}13.9 \\
13.8\end{array}$ & $\begin{array}{l}18.2 \\
18.0\end{array}$ & $\begin{array}{l}39.8 \\
40.9\end{array}$ & $\begin{array}{l}20.3 \\
20.1\end{array}$ & $\begin{array}{l}-2.1 \\
-2.0\end{array}$ & $\begin{array}{l}-1.7 \\
-1.5\end{array}$ & $\begin{array}{l}4.8 \\
3.7\end{array}$ & $\begin{array}{l}-1.9 \\
-1.7\end{array}$ & $\begin{array}{l}-.2 \\
-.3\end{array}$ & $\begin{array}{l}.2 \\
.2\end{array}$ \\
\hline $\begin{array}{l}8601 \\
8601\end{array}$ & $\begin{array}{l}07 / 30 / 84 \\
08 / 28 / 84\end{array}$ & $\begin{array}{l}43.9 \\
44.1\end{array}$ & $\begin{array}{l}41.6 \\
41.6\end{array}$ & $\begin{array}{l}63.9 \\
64.6\end{array}$ & $\begin{array}{l}39.7 \\
39.6\end{array}$ & $\begin{array}{l}-0.08 \\
-0.10\end{array}$ & $\begin{array}{l}\text { WA I } \\
\text { WAI }\end{array}$ & $\begin{array}{l}13.2 \\
13.4\end{array}$ & $\begin{array}{l}17.8 \\
17.8\end{array}$ & $\begin{array}{l}41.3 \\
42.0\end{array}$ & $\begin{array}{l}19.5 \\
19.4\end{array}$ & $\begin{array}{l}-1.4 \\
-1.6\end{array}$ & $\begin{array}{l}-1 \cdot 3 \\
-1.3\end{array}$ & $\begin{array}{l}3.3 \\
2.6\end{array}$ & $-1 \cdot 1$ & $\begin{array}{l}-.3 \\
-6\end{array}$ & -.2 \\
\hline $86 Q 1$ & $09 / 28 / 84$ & 43.7 & 41.3 & 64.5 & 39.1 & -0.03 & WAI & $\begin{array}{l}13.4 \\
13.0\end{array}$ & $\begin{array}{l}17.8 \\
17.5\end{array}$ & $\begin{array}{l}42.0 \\
41.9\end{array}$ & $\begin{array}{l}19.4 \\
18.8\end{array}$ & $\begin{array}{l}-1.6 \\
-1.2\end{array}$ & $\begin{array}{l}-1.1 \\
-1.0\end{array}$ & $\begin{array}{l}2.6 \\
2.7\end{array}$ & $\begin{array}{r}-1.0 \\
-.4\end{array}$ & $\begin{array}{l}-.6 \\
-.8\end{array}$ & $\begin{array}{l}-.3 \\
-.6\end{array}$ \\
\hline $86 Q 1$ & $10 / 30 / 84$ & 43.2 & 41.0 & 64.4 & 39.1 & +0.10 & WAI & 12.5 & 17.1 & 41.8 & 18.8 & -.7 & -.6 & 2.8 & -.4 & -.3 & -.2 \\
\hline $86 Q 1$ & $11 / 29 / 84$ & 43.8 & 41.2 & 65.2 & 39.5 & +0.07 & WA I & 13.1 & 17.4 & 42.7 & 19.3 & $-1 \cdot 3$ & -.9 & 1.9 & -.9 & -.4 & .0 \\
\hline 8601 & $12 / 31 / 84$ & 43.6 & 41.2 & 66.0 & 39.4 & +0.03 & WAI & 12.9 & 17.4 & 43.5 & 19.2 & -1.1 & -.9 & 1.1 & -.8 & -.3 & -.1 \\
\hline $86 Q 1$ & $01 / 28 / 85$ & 43.5 & 41.0 & 67.0 & 39.4 & -0.24 & WA I & 12.8 & 17.1 & 44.5 & 19.2 & -1.0 & -.6 & .1 & -.8 & -.2 & .2 \\
\hline 8601 & $02 / 28 / 85$ & 43.8 & 41.4 & 66.3 & 39.5 & +0.01 & WAI & 13.1 & 17.6 & 43.8 & 19.3 & $-1 \cdot 3$ & -1.2 & .8 & -.9 & -.4 & -.2 \\
\hline $86 Q 1$ & $03 / 28 / 85$ & 44.1 & 41.6 & 66.5 & 39.8 & -0.15 & WAI & 13.4 & 17.8 & 44.0 & 19.6 & -1.6 & -1.3 & .6 & -1.2 & -.4 & -.1 \\
\hline $86 Q 1$ & $04 / 29 / 85$ & 43.8 & 41.2 & 66.1 & 39.4 & -0.03 & WAI & 13.1 & 17.4 & 43.6 & 19.2 & -1.3 & -.9 & 1.0 & -.8 & -.5 & -.1 \\
\hline 8601 & $05 / 22 / 85$ & 43.9 & 41.5 & 66.5 & 39.5 & -0.05 & WAI & 13.2 & 17.7 & 44.0 & 19.3 & -1.4 & -1.2 & .6 & -.9 & -.5 & -.3 \\
\hline $86 Q 1$ & $06 / 10 / 85$ & 42.9 & 40.6 & 71.0 & 38.5 & -0.05 & BNA & 12.1 & 16.7 & 48.6 & 18.2 & -.3 & -.2 & -4.0 & .2 & -.5 & -.4 \\
\hline
\end{tabular}


3. N-Tables Used for Final Data Processing:

$\begin{array}{lcccrrr}\begin{array}{l}\text { N-table control } \\ \text { Inat }\end{array} & \text { N-table } & \text { From } & \text { To } & \text { Na } & \text { Nc } & \text { Nd } \\ 72 & 19660616 R 2 & 19660616 & 19690526 & .69 & .31 & -1.93 \\ 72 & 19690527 R 1 & 19690527 & 19721001 & 12.98 & 9.38 & 5.70 \\ 72 & 19721002 R 1 & 19721002 & 19760518 & 6.52 & 4.09 & -.37 \\ 72 & 19760519 R 1 & 19760519 & 99999999 & 14.64 & 10.60 & 5.16 \\ 38 & 19780921 R 1 & 19780921 & 19850507 & -17.63 & -14.67 & -15.10 \\ 38 & 19850508 M 7 & 19850508 & 19910915 & -11.35 & -9.15 & -9.92 \\ 38 & 19910916 M 8 & 19910916 & 19950426 & -13.38 & -10.57 & -10.15 \\ 38 & 19950427 M 9 & 19950427 & 9999999 & -14.54 & -11.54 & -11.54 \\ 86 & 19830526 R 1 & 19830526 & 99999999 & -30.78 & -23.54 & -19.69\end{array}$




\section{Appendix C}

\section{SAMPLE ARCHIVED DOBSON SPECTROPHOTOMETER}

OPTICAL WEDGE CALIBRATION DATA 


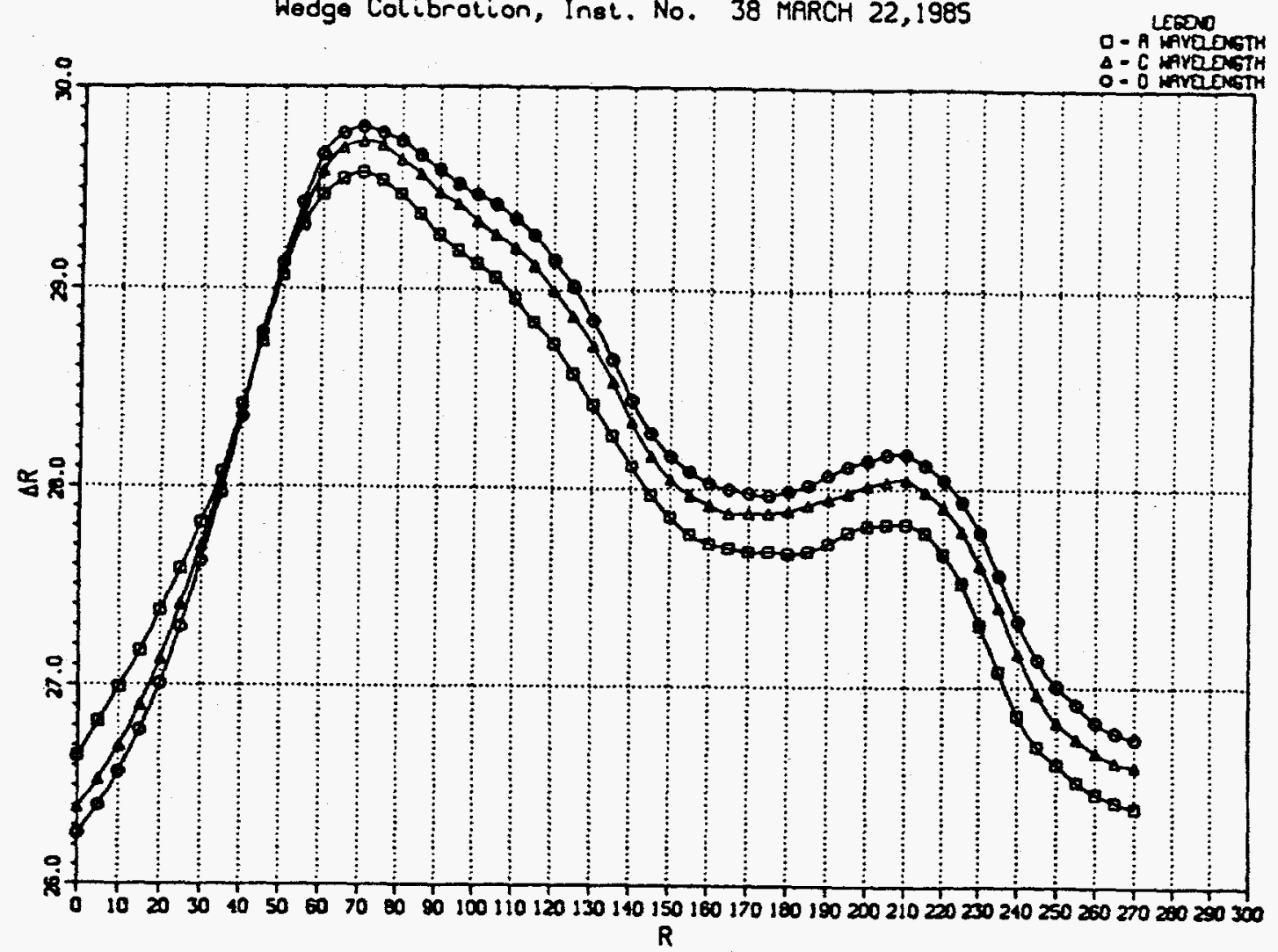

GA TABLE

\begin{tabular}{|c|c|c|c|c|c|c|c|c|c|c|}
\hline $\mathbf{R}$ & 0 & 1 & 2 & 3 & 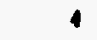 & 5 & 6 & 7 & 8 & \\
\hline $\begin{array}{r}0 \\
10 \\
20 \\
30 \\
10\end{array}$ & $\begin{array}{r}5.7 \\
17.0 \\
28.1 \\
39.1\end{array}$ & $\begin{array}{r}6.8 \\
18.1 \\
29.2 \\
10.2\end{array}$ & $\begin{array}{r}7.9 \\
19.2 \\
30.3 \\
41.3\end{array}$ & $\begin{array}{r}9.1 \\
20.4 \\
31.4 \\
12.3\end{array}$ & $\begin{array}{l}10.2 \\
21.5 \\
32.5 \\
43.4\end{array}$ & $\begin{array}{r}.0 \\
12.3 \\
22.6 \\
33.6 \\
44.5\end{array}$ & $\begin{array}{r}1.1 \\
12.5 \\
23.7 \\
34.7 \\
45.6\end{array}$ & $\begin{array}{r}2.3 \\
13.6 \\
24.8 \\
35.8 \\
46.7\end{array}$ & $\begin{array}{r}3.4 \\
5 \\
14.7 \\
25.9 \\
36.9 \\
17.8\end{array}$ & $\begin{array}{r}1.5 \\
15.9 \\
27.0 \\
38.0 \\
18.9\end{array}$ \\
\hline $\begin{array}{l}50 \\
60 \\
70 \\
80 \\
90\end{array}$ & $\begin{array}{l}9.9 \\
0.5 \\
0.8 \\
1.0 \\
1.1\end{array}$ & $\begin{array}{l}51.0 \\
61.5 \\
71.8 \\
82.0 \\
92.1\end{array}$ & $\begin{array}{l}52.1 \\
62.5 \\
72.9 \\
83.0 \\
93.2\end{array}$ & $\begin{array}{l}53.1 \\
63.6 \\
73.9 \\
84.0 \\
94.2\end{array}$ & $\begin{array}{l}54 . \\
64 . \\
74 . \\
85 . \\
95 .\end{array}$ & & $\begin{array}{l}56.3 \\
66.7 \\
76.9 \\
87.1 \\
97.2\end{array}$ & $\begin{array}{l}57.3 \\
67.7 \\
77.9 \\
88.1 \\
98.3\end{array}$ & $\begin{array}{l}58.4 \\
68.7 \\
79.0 \\
89.1 \\
99.3\end{array}$ & $\begin{array}{r}59.4 \\
69.8 \\
80.0 \\
90.1 \\
100.3\end{array}$ \\
\hline $\begin{array}{l}10 \\
0 \\
0 \\
0 \\
0\end{array}$ & $\begin{array}{l}101.3 \\
111.6 \\
122.0 \\
132.4 \\
142.9\end{array}$ & & & & & & & & & \\
\hline $\begin{array}{l}50 \\
60 \\
70 \\
80 \\
90\end{array}$ & $\begin{array}{l}4 \\
2 \\
0 \\
9\end{array}$ & & & & & $\begin{array}{l}58.8 \\
69.6 \\
80.4 \\
91.3 \\
02.2\end{array}$ & & & $\begin{array}{l}.0 \\
.8 \\
.7 \\
.6 \\
.5\end{array}$ & \\
\hline $\begin{array}{l}0 \\
0 \\
0 \\
0\end{array}$ & $\begin{array}{l}18.5 \\
9.3 \\
10.2 \\
1.0\end{array}$ & & & & & $\begin{array}{l}213.1 \\
223.9 \\
234.7 \\
245.5 \\
256.5\end{array}$ & $\begin{array}{l}.2 \\
.0 \\
.8\end{array}$ & & & \\
\hline 50 & 3.3 & $\begin{array}{l}297.1 \\
308.6\end{array}$ & $\begin{array}{l}298.2 \\
309.7\end{array}$ & & & $\begin{array}{l}261.6 \\
279.0 \\
290.3 \\
301.7 \\
313.2\end{array}$ & 302.8 & $\begin{array}{l}69.9 \\
81.2 \\
92.5 \\
04.0\end{array}$ & & \\
\hline
\end{tabular}


GC TABLE

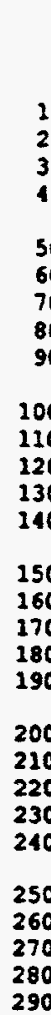

$\mathbf{R}$

10

20
30

10

50

60

80

90

100

110

140

150

160

170
180

190

200

210
220

230

240

250

280

290

\begin{tabular}{|c|c|c|c|c|c|c|c|c|c|}
\hline 0 & 1 & 2 & 3 & 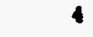 & 5 & 6 & 7 & 8 & 3 \\
\hline $\begin{array}{l}5.7 \\
17.1 \\
28.4 \\
39.5\end{array}$ & $\begin{array}{r}6.9 \\
18.3 \\
29.5 \\
40.6\end{array}$ & $\begin{array}{r}8.0 \\
29.4 \\
30.6 \\
41.7\end{array}$ & $\begin{array}{r}9.2 \\
20.5 \\
31.7 \\
42.8\end{array}$ & $\begin{array}{l}10.3 \\
21.7 \\
32.8 \\
43.8\end{array}$ & $\begin{array}{l}.0 \\
11.5 \\
22.8 \\
34.0 \\
14.9\end{array}$ & $\begin{array}{l}1.1 \\
12.6 \\
23.9 \\
35.1 \\
46.0\end{array}$ & $\begin{array}{r}2.3 \\
13.7 \\
25.0 \\
36.2 \\
47.1\end{array}$ & $\begin{array}{r}3.1 \\
14.9 \\
26.2 \\
37.3 \\
48.2\end{array}$ & $\begin{array}{r}4.6 \\
16.0 \\
27.3 \\
38.4 \\
49.2\end{array}$ \\
\hline $\begin{array}{l}50.3 \\
60.9 \\
71.2 \\
81.3 \\
91.4\end{array}$ & $\begin{array}{l}51.4 \\
61.9 \\
72.2 \\
82.4 \\
92.5\end{array}$ & $\begin{array}{l}52.5 \\
63.0 \\
73.3 \\
83.4 \\
93.5\end{array}$ & $\begin{array}{l}53.5 \\
64.0 \\
74.3 \\
84.4 \\
94.5\end{array}$ & $\begin{array}{l}54.6 \\
65.1 \\
75.3 \\
85.4 \\
95.5\end{array}$ & $\begin{array}{l}55.6 \\
66.1 \\
76.3 \\
86.1 \\
96.5\end{array}$ & $\begin{array}{l}56.7 \\
67.1 \\
77.3 \\
87.4 \\
97.5\end{array}$ & $\begin{array}{l}57.7 \\
68.2 \\
78.3 \\
88.4 \\
98.6\end{array}$ & $\begin{array}{l}58.8 \\
69.2 \\
79.3 \\
89.4 \\
99.6\end{array}$ & $\begin{array}{r}59.9 \\
70.2 \\
80.3 \\
90.4 \\
100.6\end{array}$ \\
\hline $\begin{array}{l}101.6 \\
111.8 \\
122.1 \\
132.4 \\
142.7\end{array}$ & $\begin{array}{l}102.6 \\
112.8 \\
123.1 \\
133.4 \\
143.8\end{array}$ & $\begin{array}{l}103 \\
113 \\
128 \\
134 \\
14\end{array}$ & $\begin{array}{l}104.7 \\
114.9 \\
125.2 \\
135.5 \\
145.9\end{array}$ & $\begin{array}{l}105.7 \\
115.9 \\
126.2 \\
136.5 \\
146.9\end{array}$ & $\begin{array}{l}106.7 \\
116.9 \\
127.2 \\
137.6 \\
148.0\end{array}$ & $\begin{array}{l}107.7 \\
118.0 \\
128.3 \\
138.6 \\
149.0\end{array}$ & $\begin{array}{l}108.7 \\
129.0 \\
129.3 \\
139.6 \\
150.1\end{array}$ & $\begin{array}{l}109.8 \\
120.0 \\
130.3 \\
140.7 \\
151.1\end{array}$ & $\begin{array}{l}110.8 \\
121.0 \\
131.4 \\
141.7 \\
152.2\end{array}$ \\
\hline $\begin{array}{l}153.2 \\
163.9 \\
174.6 \\
185.1 \\
196.2\end{array}$ & $\begin{array}{l}154.3 \\
164.9 \\
175.7 \\
186.5 \\
197.3\end{array}$ & $\begin{array}{l}155.3 \\
166.0 \\
176.8 \\
187.6 \\
198.4\end{array}$ & $\begin{array}{l}156.1 \\
167.1 \\
177.9 \\
188.7 \\
199.5\end{array}$ & $\begin{array}{l}157.5 \\
168.2 \\
179.0 \\
189.7 \\
200.5\end{array}$ & $\begin{array}{l}158.5 \\
169.2 \\
180.0 \\
190.8 \\
201.6\end{array}$ & $\begin{array}{l}159.6 \\
170.3 \\
181.1 \\
191.9 \\
202.7\end{array}$ & $\begin{array}{l}160.7 \\
271.4 \\
182.2 \\
193.0 \\
203.0\end{array}$ & $\begin{array}{l}161.7 \\
172.5 \\
183.3 \\
194.1 \\
204.9\end{array}$ & $\begin{array}{l}162.8 \\
173.6 \\
184.3 \\
195.1 \\
205.9\end{array}$ \\
\hline $\begin{array}{l}207.0 \\
227.8 \\
228.5 \\
239.3 \\
250.0\end{array}$ & $\begin{array}{l}208.1 \\
218.9 \\
229.6 \\
240.3 \\
251.1\end{array}$ & $\begin{array}{l}209.2 \\
219.9 \\
230.7 \\
241.4 \\
252.2\end{array}$ & $\begin{array}{l}210.3 \\
221.0 \\
231.7 \\
242.5 \\
253.3\end{array}$ & $\begin{array}{l}211.3 \\
222.1 \\
232.8 \\
243.6 \\
254.4\end{array}$ & $\begin{array}{l}212.4 \\
223.1 \\
233.9 \\
244.6 \\
255.4\end{array}$ & $\begin{array}{l}213.5 \\
224.2 \\
235.0 \\
245.7 \\
256.5\end{array}$ & & $\begin{array}{l}215.6 \\
226.4 \\
237.1 \\
247.8 \\
258.7\end{array}$ & $\begin{array}{l}216 \\
227 \\
238 \\
248 \\
259\end{array}$ \\
\hline $\begin{array}{l}260 . \\
272 . \\
283 . \\
294 .\end{array}$ & $\begin{array}{l}26 \\
27 \\
28 \\
29 \\
30\end{array}$ & $\begin{array}{l}263.1 \\
274.3 \\
285.6 \\
296.8 \\
308.2\end{array}$ & $\begin{array}{l}264.2 \\
275.4 \\
286.7 \\
298.0 \\
309.3\end{array}$ & $\begin{array}{l}265 \\
276 \\
287 \\
299 \\
310\end{array}$ & $\begin{array}{l}266.5 \\
277.7 \\
289.0 \\
300.2 \\
311.6\end{array}$ & $\begin{array}{l}267.6 \\
278.8 \\
290.1 \\
301.4 \\
312.7\end{array}$ & $\begin{array}{l}268.7 \\
279.9 \\
291.2 \\
302.5\end{array}$ & $\begin{array}{l}269.8 \\
281.0 \\
292.3 \\
303.6\end{array}$ & $\begin{array}{l}270.9 \\
282.2 \\
293.5 \\
304.8\end{array}$ \\
\hline
\end{tabular}

Go TABLE

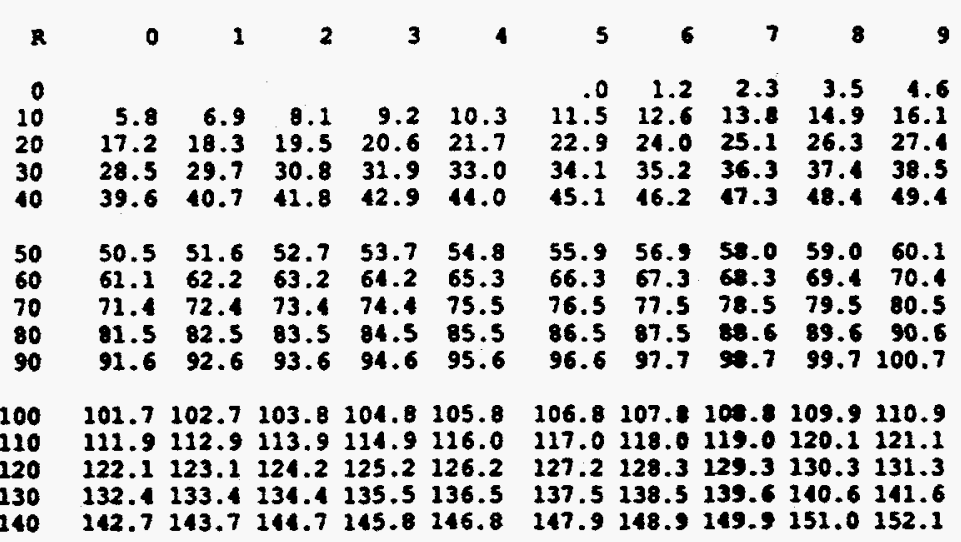

$153.1154 .2155 .2156 .3157 .3 \quad 158.4159 .4160 .3161 .6162 .6$ $163.7164 .8 \quad 165.8 \quad 166.9168 .0 \quad 169.1 \quad 170.1 \quad 171.2 \quad 172.3173 .4$ $174.4175 .5176 .6177 .7178 .7 \quad 179.8 \quad 180.9101 .9183 .0184 .1$ $185.2186 .2187 .3 \quad 186.4189 .5 \quad 190.5191 .6192 .7193 .8194 .8$ $195.9197 .0198 .1199 .2200 .2 \quad 201.3202 .4203 .5204 .6205 .6$

$206.7207 .8 \quad 208.9209 .9211 .0 \quad 212.1213 .1214 .2 \quad 215.3216 .3$ $217.4218 .5219 .5220 .6221 .7 \quad 222.7223 .8224 .9226 .0227 .0$ $228.1229 .2230 .2 \quad 231.3232 .4 \quad 233.4234 .5235 .6236 .6237 .7$ $238.8239 .9240 .9242 .0243 .1 \quad 244.1245 .2246 .3247 .3248 .4$ $249.5250 .6 \quad 251.6 \quad 252.7 \quad 253.8 \quad 254.9256 .0257 .2 \quad 258.1259 .2$

$260.3261 .4262 .5263 .6264 .7 \quad 265.8266 .9264 .0269 .1270 .3$ $271.4272 .5273 .6274 .7275 .8 \quad 277.0278 .1279 .2280 .3281 .4$ $282.6283 .7284 .8285 .9287 .1 \quad 288.2 \quad 289.3290 .4291 .5292 .7$ $293.8294 .9296 .0 \quad 297.1298 .3 \quad 299.4300 .5301 .7302 .8303 .9$ 305.0306 .2 
Appendix D

SAMPLE ARCHIVED DOBSON

SPECTROPHOTOMETER CALIBRATION DATA 


\section{Dobson Ozone Spectrophotometer Calibration Observations}

Place: Bowder, Colrado

Date: Sest. 16, 1991

A.M.IP.M.

A.M. $\frac{\text { U.S.A. (Wallop 2 }) \text { Inst. No. } 3 \text { B vs }}{\text { (Country) }}$ U.S.A. Inst. No. 83 (Country)

For instrument No. 38 use $G$ tables dated March 22,1985 Apply the following corrections to the tables:

To GA or NA values add $N A$

To $\mathrm{GC}$ or $\mathrm{NC}$ values add $N A$

To GD or ND values add $N A$

For instrument No. 83 use $N$ tables dated Qug. 26, $1991 \mathrm{FI}$ Apply the following corrections to the tables:

To GA or NA values add $+0.3$

To $\mathrm{GC}$ or NC values add $+0.2$

To GD or ND values add $+0.3$

Notes: '2nitial ealibrstion'. 
$95 / 11 / 03.16 .21 .47$.

Instruments 83 and 38 Compared

at BOULDER, COLORADO U.S.A.

September 16, 1991 AM

New II BK 03 ABS. COEFFICIENTS applied.

Ozone at

23000. meters.

Station Elevation

1634.0 meters.

Mean station Presaure $\quad 034.00$ millibars.

Station Earth Radius 6369553.0 meters.

$\begin{array}{rcccc}\text { Absorption Coefficients: } & \text { A } & \text { B } & \text { C } & \text { D } \\ \text { Alpha: } & 1.806 & 1.192 & .833 & .374 \\ \text { Beta: } & .114 & .111 & .109 & .104\end{array}$

Mu fit min: 1.1500 Mu fit $\max : 3.6000$

Inst rument $38 \mathrm{G}$ Tables dated

Corrections to G Tables:

NOT AVAILABLE

Instrument $83 \mathrm{~N}$ Tables dated

August $26,1991 \mathrm{Fl}$

March 22, $1985 \mathrm{~N}$

Corrections to $\mathrm{N}$ Tables:

To NA values ADI

To NC: values ADD

.30

To ND values ADD

.30 
From:

May 31, 1990

10
20

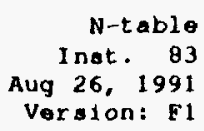

$\begin{array}{rrrrr}0 & 1 & 2 & 3 & 4 \\ & & & & \\ -6.6 & -5.5 & -4.4 & -3.3 & -2.3 \\ 4.2 & 5.3 & 6.4 & 7.4 & 8.5 \\ 14.8 & 15.8 & 16.9 & 17.9 & 19.0 \\ 25.2 & 26.2 & 27.2 & 28.2 & 29.3 \\ 35.3 & 36.3 & 37.3 & 30.2 & 39.2 \\ & & & & \\ 45.0 & 46.0 & 46.9 & 47.9 & 48.8 \\ 54.4 & 55.4 & 56.3 & 57.2 & 58.2 \\ 63.7 & 64.6 & 65.5 & 66.4 & 67.4 \\ 73.0 & 73.9 & 74.8 & 75.8 & 76.7\end{array}$

$\begin{array}{llllll}82.4 & 83.3 & 84.2 & 05.2 & 86.1\end{array}$

$\begin{array}{llllll}91.7 & 92.7 & 93.6 & 94.5 & 95.5\end{array}$ $\begin{array}{lllll}01.1 & 102.0 & 103.0 & 103.9 & 104.9\end{array}$ $110.5111 .4 \quad 112.4113 .3 \quad 114.3$ $119.9120 .8 \quad 121.8 \quad 122.7 \quad 123.7$

139.1140 .0141 .0142 .0142 .9 148.7149 .7150 .7151 .7152 .7153 .6154 .6155 .6156 .6157 .6

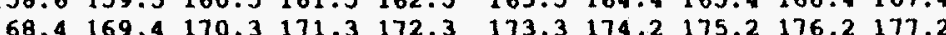

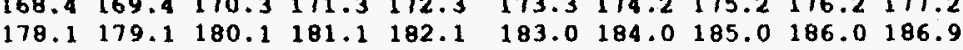

$\begin{array}{llllllllll}187.9 & 188.9 & 189.9 & 190.9 & 191.8 & 192.8 & 193.8 & 194.8 & 195.8 & 196.7\end{array}$ $197.7 \quad 198.7 \quad 199.7200 .7201 .7 \quad 202.7203 .6204 .6205 .6 \quad 206.6$ $207.6208 .6209 .6 \quad 210.6211 .7 \quad 212.7 \quad 213.7214 .7215 .7 \quad 216.7$ $\begin{array}{llllllllll}217.7 & 218.8 & 219.8 & 220.8 & 221.8 & 222.8 & 223.9 & 224.9 & 225.9 & 227.0 \\ 228.0 & 229.0 & 230.1 & 231.1 & 232.1 & 233.2 & 234.2 & 235.2 & 236.3 & 237.3\end{array}$

$238.3239 .4240 .4241 .4242 .5 \quad 243.5244 .5 \quad 245.6 \quad 246.6247 .6$ $240.6240 .6290 .6,251.6232 .6,293.6,254.629 .7256 .729 \%$

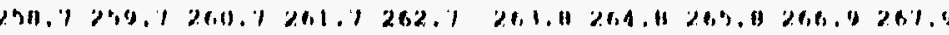
270.02710272 .0273 .1274 .1273 .1276 .2277 .2278 .2

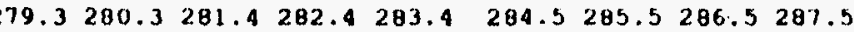

From:

Gay 31, 1990

$N-$ table

Inst. 83 Aug 26,1991
Vaxbion: $F 1$

NC table

$\begin{array}{rrrrrrrrrr}0 & 1 & 2 & .3 & 4 & 5 & 6 & 7 & 8 & 9 \\ -3.3 & -2.2 & -1.1 & -.0 & 1.0 & 2.1 & 3.2 & 4.3 & 5.4 & 6.5 \\ 7.5 & 8.6 & 9.7 & 10.7 & 11.8 & 12.8 & 13.9 & 14.9 & 16.0 & 17.0 \\ 18.0 & 19.1 & 20.1 & 21.1 & 22.2 & 23.2 & 24.2 & 25.2 & 26.3 & 27.3 \\ 28.3 & 29.3 & 30.4 & 31.4 & 32.4 & 33.4 & 34.4 & 35.4 & 36.4 & 37.5 \\ 38.5 & 39.4 & 40.4 & 41.4 & 42.4 & 43.3 & 44.3 & 45.3 & 46.2 & 17.1 \\ & & & & & & & & & \\ 48.1 & 49.0 & 50.0 & 50.9 & 51.9 & 52.8 & 53.7 & 54.7 & 55.6 & 56.5 \\ 57.4 & 58.4 & 59.3 & 60.2 & 61.1 & 62.1 & 63.0 & 63.9 & 64.8 & 65.7 \\ 66.7 & 67.6 & 68.5 & 69.4 & 70.3 & 71.2 & 72.2 & 73.1 & 74.0 & 74.9 \\ 75.8 & 76.8 & 77.7 & 78.6 & 79.5 & 80.5 & 81.4 & 82.3 & 83.2 & 84.2 \\ 85.1 & 86.0 & 86.9 & 87.9 & 88.8 & 89.7 & 90.7 & 91.6 & 92.5 & 93.4\end{array}$

$94.495 .3 \quad 96.2 \quad 97.2 \quad 99.1$ $94.495 .396 .2 \quad 97.2 \quad 98.1$ 112.9113 .9114 .8115 .7116 .6 122.2123 .1124 .0125 .0125 .9

$99.0100 .0 \quad 100.9101 .8102 .8$ $108.3109 .3 \quad 110.2111 .1112 .0$ 117.6118 .5119 .4120 .3121 .2 $126.8127 .8128 .7 \quad 129.6 \quad 130.6$

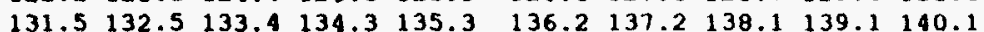

$141.0142 .0 \quad 142.9143 .9144 .8$ $150.5 \quad 151.5 \quad 152.4 \quad 153.4 \quad 154.4$ 155.3156 .7147 .7148 .6149 .6 $160.1161 .1162 .1163 .0164 .0 \quad 165.0165 .9156 .91567 .9159 .2$ $169.8170 .8171 .8172 .7173 .7 \quad 174.6175 .6176 .6177 .5178 .5$

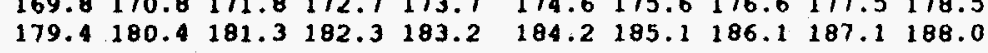

$\begin{array}{llllllllll}189.0 & 189.9 & 190.9 & 191.9 & 192.8 & 193.8 & 194.8 & 195.7 & 196.7 & 197.7\end{array}$ $198.6199 .6200 .6201 .6 \quad 202.5 \quad 203.5 \quad 204.5 \quad 205.5 \quad 206.4 \quad 207.4$ $208.4209 .4210 .4211 .4212 .4 \quad 213.3214 .3215 .3216 .3217 .3$ $218.3219 .3220 .3221 .3222 .4 \quad 223.4224 .4225 .4226 .4227 .4$ $228.4229 .5230 .5231 .5232 .5 \quad 233.5234 .6 \quad 235.6 \quad 236.6 \quad 237.6$

$238.7239 .7240 .7241 .7242 .7 \quad 243.7244 .8245 .8246 .8247 .8$ $240.8249 .8250 .8251 .0252 .8 \quad 253.0254 .0299 .1296 .1231 .1$ 294.7259 .1261 .7261 .1262 .026 .1 .0264 .11269 .1126 .6 .11261 .11 $268.8269 .9270 .9271 .9272 .9273 .9275 .0276 .0271 .02 \% 0.0$ $279.0280 .0 \quad 281.0 \quad 282.1283 .1 \quad 284.1 \quad 285.1$ 
GC table

10
20
40
50
60

101.6102 .6103 .6104 .7105 .7 111.8112 .8113 .9114 .9115 .9 $122.1 \quad 123.1 \quad 124.1 \quad 125.2126 .2$ 142.7143 .8144 .8145 .9146 .9

$\begin{array}{rrrrrrrrrr}0 & 1 & 2 & 3 & 4 & 5 & 6 & 7 & 8 & 9 \\ -5.7 & -4.6 & -3.4 & -2.3 & -1.1 & .0 & 1.1 & 2.3 & 3.4 & 4.6 \\ 5.7 & 6.9 & 0.0 & 9.2 & 10.3 & 11.5 & 12.6 & 13.7 & 14.9 & 16.0 \\ 17.1 & 18.3 & 19.4 & 20.5 & 21.7 & 22.8 & 23.9 & 25.0 & 26.2 & 27.3 \\ 28.4 & 29.5 & 30.6 & 31.7 & 32.8 & 34.0 & 35.1 & 36.2 & 37.3 & 38.4 \\ 39.5 & 40.6 & 41.7 & 42.7 & 43.8 & 44.9 & 46.0 & 47.1 & 48.2 & 49.2 \\ & & & & & & & & & \\ 50.3 & 51.4 & 52.5 & 53.5 & 54.6 & 55.6 & 56.7 & 57.8 & 58.8 & 59.9 \\ 60.9 & 61.9 & 63.0 & 64.0 & 65.1 & 66.1 & 67.1 & 68.2 & 69.2 & 70.2 \\ 71.2 & 72.2 & 73.3 & 74.3 & 75.3 & 76.3 & 77.3 & 78.3 & 79.3 & 80.3 \\ 81.3 & 82.3 & 83.4 & 84.4 & 95.4 & 86.4 & 87.4 & 88.4 & 89.4 & 90.4 \\ 91.4 & 92.5 & 93.5 & 94.5 & 95.5 & 96.5 & 97.5 & 98.6 & 99.6 & 100.6\end{array}$

$106.7107 .7 \quad 108.7 \quad 109.8110 .8$ 116.9118 .0119 .0120 .0121 .0 127.2128 .3129 .0120 .0121 .0 $137.6138 .6 \quad 139.6140 .7141 .7$ 158.5159 .6160 .7161 .7162 .8 $\begin{array}{llllllllll}163.9 & 164.9 & 166.0 & 167.1 & 168.2 & 169.2 & 170.3 & 171.4 & 172.5 & 173.6\end{array}$ $174.6 \quad 175.7 \quad 176.8 \quad 177.9179 .0 \quad 180.0 \quad 181.1 \quad 182.2 \quad 183.3 \quad 184.3$ $\begin{array}{lllllllllll}185.4 & 186.5 & 187.6 & 188.7 & 189.7 & 190.8 & 191.9 & 193.0 & 194.1 & 195.1 \\ 196.2 & 197.3 & 198.4 & 199.5 & 200.5 & 201.6 & 202.7 & 203.8 & 204.9 & 205.9\end{array}$

$207.0208 .1209 .2 \quad 210.3211 .3 \quad 212.4 \quad 213.5214 .6 \quad 215.6216 .7$ $217.8218 .9219 .9221 .0222 .1 \quad 223.1224 .2 \quad 225.3226 .4227 .4$ $228.5229 .6230 .7231 .7232 .8 \quad 233.9235 .0236 .0 \quad 237.1 \quad 238.2$ $239.3240 .3241 .4242 .5 \quad 243.5 \quad 244.6 \quad 245.7 \quad 246.8247 .8248 .9$ $250.0251 .1252 .2253 .3254 .3 \quad 255.4256 .5257 .6258 .7259 .8$

$260.9262 .0263 .1264 .2 \quad 265.3 \quad 266.5 \quad 267.6268 .7269 .8270 .9$ $272.0273 .2274 .3275 .4276 .5 \quad 277.6 \quad 278.8279 .9281 .0282 .2$ $283.3284 .4285 .6286 .7287 .8 \quad 289.0290 .1291 .2292 .3293 .5$ $294.6295 .7296 .8298 .0299 .1 \quad 300.2301 .4302 .5303 .6 \quad 304.8$ $\begin{array}{lllllll}05.9 & 307.0 & 308.2 & 309.3 & 310.4 & 311.6 & 312.7\end{array}$
G-table Inat. 38 Max 22, 1985 Veroion: $N$

GD table

\begin{tabular}{|c|c|c|c|c|c|c|c|c|c|}
\hline 0 & 1 & 2 & 3 & 4 & 5 & 6 & 7 & 8 & \\
\hline .8 & 4.6 & -3.5 & 2.3 & -1.2 & .0 & 1.2 & 2.3 & 3.5 & \\
\hline 5. & 6.8 & 8.1 & 9. & & 1.5 & & & & \\
\hline 7.2 & 18.3 & 19.5 & 20.6 & 21. & 2.9 & 24.0 & 25.1 & 26.3 & \\
\hline 9 & 29.6 & 30.8 & 31.9 & 33 & 1 & & 36. & 37.4 & \\
\hline . & 40. & 41. & 42. & 44. & 5.1 & 46. & 47.3 & 48.4 & \\
\hline . & 5 & 52. & 3. & & 9 & 56 & 58 & & \\
\hline . & 62.2 & 63.2 & 64.2 & & 56. & & 68.3 & 69.4 & 70. \\
\hline 2. & 72.4 & 73.4 & 74.5 & 75 & 5 & 77 & 78.5 & 79.5 & \\
\hline & 82.5 & 83.5 & 84.5 & 85.5 & 86.5 & 87.5 & 88.6 & 89.6 & \\
\hline 6 & 92.6 & 93.6 & 94.6 & 95.6 & 96.6 & 97.7 & 98.7 & 99.7 & 100. \\
\hline
\end{tabular}
$111.9112 .9113 .9115 .0116 .0 \quad 117.0 \quad 118.0119 .0120 .1121 .1$

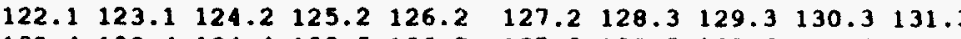

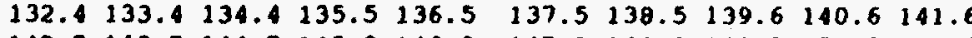
$142.7143 .7144 .7145 .8146 .8 \quad 147.9148 .9149 .9151 .0152 .0$

$\begin{array}{llllllllll}153.1 & 154.2 & 155.2 & 156.3 & 157.3 & 158.4 & 159.4 & 160.5 & 161.6 & 162.6\end{array}$ $\begin{array}{lllllllllll}163.7 & 164.8 & 165.8 & 166.9 & 168.0 & 169.1 & 170.1 & 171.2 & 172.3 & 173.4\end{array}$ $\begin{array}{llllllllll}174.4 & 175.5 & 176.6 & 177.7 & 178.7 & 179.8 & 180.9 & 181.9 & 183.0 & 184.1\end{array}$ $\begin{array}{lllllllllll}185.2 & 186.2 & 187.3 & 188.4 & 189.5 & 190.5 & 191.6 & 192.7 & 193.8 & 194.8\end{array}$ $195.9197 .0198 .1 \quad 199.2 \quad 200.2 \quad 201.3202 .4203 .5 \quad 204.6205 .6$

$206.7207 .8208 .9209 .9211 .0 \quad 212.1213 .1214 .2215 .3216 .4$

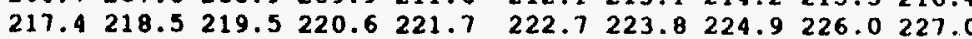

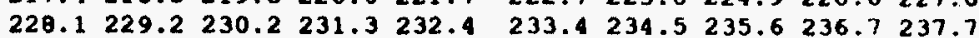

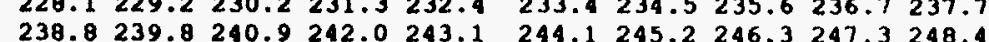
$249.5250 .6251 .6252 .7253 .8 \quad 254.9256 .0257 .1258 .1259 .2$

$260.3261 .4262 .5263 .6264 .7 \quad 265.9266 .9268 .0269 .1270 .3$ $271.4272 .5273 .6274 .7275 .9277 .0278 .1279 .2 \quad 280.3291 .5$ $282.6283 .7284 .8285 .9287 .1 \quad 288.2289 .3290 .4291 .5292 .7$

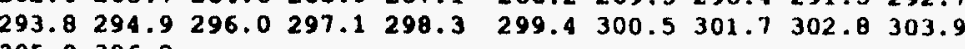
305.0306 .2 
07:03:00 3.803 3.926 A $248.20 \quad 239.30 \quad 236.8 \quad 250.2 \quad-13.4$

07:03:00 $3.717 \quad 3.832$ C $132.60133 .40124 .8 \quad 135.9$

$07: 05: 30 \quad 3.6973 .809 \mathrm{CD}$

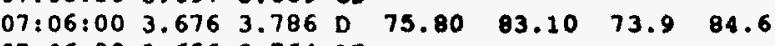

$07: 06: 30 \quad 3.656 \quad 3.764$ AD

07:07:00 $3.636 \quad 3.742$ A $238.00 \quad 230.30226 .2 \quad 240.4 \quad-14.2$

$07: 09: 00 \quad 3.557 \quad 3.656$ C $126.50127 .80119 .1 \quad 130.1$

$07: 09: 30 \quad 3.538 \quad 3.636 \mathrm{CD}$

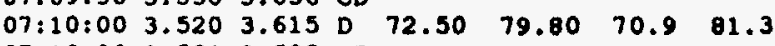

$07: 10: 30 \quad 3.501 \quad 3.595$ AD

07:11:00 $3.483 \quad 3.575$ A $228.00221 .30216 .8230 .7 \quad-13.9$

$07: 13: 003.4113 .497$ C 121.00

114.2

$07: 13: 303.3943 .478 \mathrm{CD}$

$\begin{array}{llllllll}07: 14: 00 & 3.376 & 3.459 & \mathrm{D} & 69.30 & 76.70 & 67.9 & 78.2\end{array}$

$07: 14: 303.3593 .441$ AD

$07: 15: 003.342 \quad 3.423$ A $219.90213 .30207 .8222 .1 \quad-14.2$

$07: 17: 00 \quad 3.276 \quad 3.352$ C $116.50 \quad 118.50 \quad 109.9 \quad 120.5$

$07: 17: 30 \quad 3.260 \quad 3.334 \mathrm{CD}$

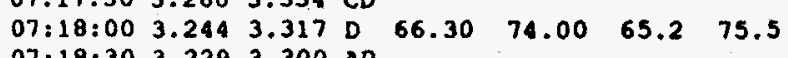

$07: 18: 30 \quad 3.229 \quad 3.300 \quad A 0$

$07: 19: 003.213 \quad 3.284$ \& 211.70

199.7

$\begin{array}{llllllll}07: 21: 00 & 3.152 & 3.219 & \mathrm{C} & 111.50 & 114.30 & 105.3 & 116.2\end{array}$

$63.90 \quad 71.80 \quad 63.0 \quad 73.2$

$07: 22: 003.123 \quad 3.187 \mathrm{D}$

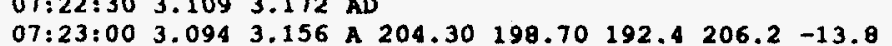

07:23:00 $3.094 \quad 3.156$ A $204.30 \quad 198.70192 .4 \quad 206.2$-13.8

$07: 25: 00 \quad 3.038 \quad 3.096$ C $107.40 \quad 110.30 \quad 101.5 \quad 112.1$

$07: 25: 303.0243 .082 \mathrm{CD}$

$07: 26.003 .0113 .067$ D $61.00 \quad 69.60 \quad 60.3 \quad 71.0$

$07: 26: 302.997 \quad 3.053$ AD

$07: 27.002 .9843 .039$ A $196.80 \quad 191.70185 .1 \quad 198.6 \quad-13.5$

$07: 29: 002.9322 .984$ C $103.40 \quad 97.7$

$07: 29: 302.9192 .970 \mathrm{CD}$

$07: 30: 002.907 \quad 2.957$ D $59.00 \quad 67.40 \quad 38.5 \quad 68.8$

$07: 30: 302.894 \quad 2.944$ AD

07:31:00 2.882 2.931 A $190.30186 .00178 .7 \quad 192.4 \quad-13.6$

$07: 33: 002.8342 .880 \mathrm{C} 99.90 \quad 103.60$ 94.5 105.3

$07.33 .302 .8342 .880 \mathrm{C}$

$99.90103 .60^{94.5} 105.3^{-13.6}-10.8$

-11.2
-11.1
-11.0

$07: 34: 002.8102 .855 \mathrm{D}$

$56.50 \quad 56.2$

$07: 34: 302.7992 .843$ AD

07:35:00 $2.787 \quad 2.831$ A $184.20 \quad 181.00 \quad 172.8 \quad 186.9 \quad-14.2$

$07: 37: 002.742 \quad 2.784$ C $96.40 \quad 100.70 \quad 91.2102 .3$

$07: 37: 30 \quad 2.731 \quad 2.772 \mathrm{CD}$

07:38:00 $2.721 \quad 2.761$ D $54.50 \quad 63.70 \quad 54.3 \quad 64.9$

$07: 38: 30 \quad 2.7102 .749 \mathrm{AD}$

07:39:00 2.699 2.73 A $178.80 \quad 175.70 \quad 167.5 \quad 181.2 \quad-13.7$

$07: 41,002.657 \quad 2.694 \mathrm{C} \quad 93,30 \quad 97.70 \quad 88.3 \quad 99.3$

$07: 41: 302.6472 .683 \mathrm{CD}$

07:42:00 $2.637 \quad 2.673$ D $52.90 \quad 62.10 \quad 52.8 \quad 63.3$

$07: 42: 30 \quad 2.627 \quad 2.662 \quad A D$

$07: 43: 002.6172 .652$ A $173.30171 .10162 .1 \quad 176.2-14.1$ .303 .383 $\begin{array}{rr}.288 & .295 \\ .291 & .313\end{array}$ .291

.28

$-10.2 \quad .304 .385$ .288 .296 .291 .315 .293 .331 .284 .286

$\begin{array}{lll}-10.3 & .303 & .388\end{array}$

.288

$-10.9$

$\begin{array}{lll}-10.9 & .291 & .333 \\ & .279 & .283\end{array}$

\begin{tabular}{lll}
$-10.2 \quad .306 .393$ \\
\hline
\end{tabular}

$.288 \quad .296 \quad-.008$

$-10.7$

$\begin{array}{rr}.291 & .316 \\ .291 & .333\end{array}$

.291 .333

$\begin{array}{rrrr} & & .282 & .281 \\ -10.7 & .302 & .397\end{array}$

$\begin{array}{lll}.302 & .397 & \\ .287 & .294 & -.007\end{array}$

.291 .316

.291

$\begin{array}{rrr}-10.3 \quad .305 & .399\end{array}$

$\begin{array}{lll}.305 & .399 & \\ .287 & .295 & -.008\end{array}$

$\begin{array}{rr}.287 & .295 \\ .291 & .317\end{array}$

$\begin{array}{rr}.291 & .317 \\ .291 & .337\end{array}$

.282

.302

.287

.290 .319

.290 .339

$-11.1$

.281 .284

$\begin{array}{lll}-10.6 & .302 & .284 \\ & .306\end{array}$

.288 .296

.291 .319

$\begin{array}{rr}.290 & .339 \\ .279 & .282\end{array}$

$-10.5 \quad .304 \quad .410$

$.287 .297-.010$

.290 .320

$\begin{array}{llllllll} & & & & & & & \\ X C D & N 038 & X 03 \theta & X A D & X C D & X A & X C & X D\end{array}$ 1083- $1083-\quad 1083-1083-1083-1083-1083-$ $038)$ 038) 038) 038) 038)

$$
\begin{aligned}
& \begin{array}{llll}
-.003 & 131.1 & .293 & \\
.284 & -.002 & -.002
\end{array}
\end{aligned}
$$

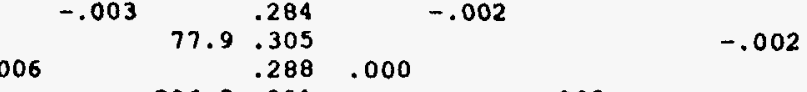

$$
\begin{aligned}
& -.002 \begin{array}{rr}
236.8 & .291 \\
125.3 & .294
\end{array} \quad .000-.002
\end{aligned}
$$

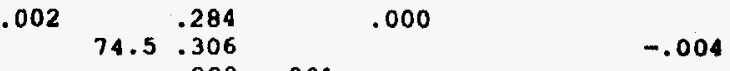

$$
\begin{aligned}
& \begin{array}{rrrr}
227.0 & .292 & -.001 & \\
119.5 & .293 & -.001 & \\
-.003 & .282 & -.001 & \\
.305 & &
\end{array} \\
& \begin{array}{r}
71.2 \\
.305 \\
.289
\end{array} \\
& 217.3 \quad .292 \\
& -.000 \\
& 68.0 \cdot 304 \\
& .289-.002 \\
& 208.7 .293 \\
& -.002 \quad .293 \\
& 65.3 \stackrel{.283}{.304} \\
& -.001 \\
& -.004^{105.6} \begin{array}{r}
.292 \\
.281
\end{array} \quad-.002 \quad-.001
\end{aligned}
$$

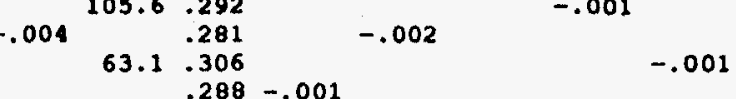

$$
\begin{aligned}
& \begin{array}{r}
192.8 .292-001-001 \\
101.5-.291
\end{array} \\
& 001+101.5 \cdot 291 \\
& 60.8 .307 \quad-003 \quad-.005 \\
& \begin{array}{rrrr}
185.2 & .286 & .001 & -.000
\end{array} \\
& \begin{array}{rl}
58.6 & .306 \\
.287 & -.000 \\
179.0 & .291
\end{array} \\
& 94.7 .292 \\
& \text {. } \\
& -.001 \\
& -.000-.001
\end{aligned}
$$

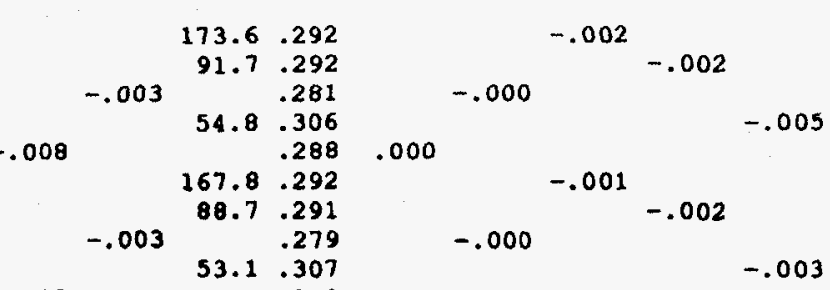

$$
\begin{aligned}
& 162.8 \quad .298 \\
& -.001
\end{aligned}
$$


ND table

GA table

$\begin{array}{rrrrrrrrrrr}\mathbf{R} & 0 & 1 & 2 & 3 & 4 & 5 & 6 & 7 & 8 & 9 \\ 0 & -1.5 & -.4 & .7 & 1.8 & 2.8 & 3.9 & 5.0 & 6.1 & 7.1 & 8.2 \\ 10 & 9.3 & 10.4 & 11.4 & 12.5 & 13.5 & 14.6 & 15.7 & 16.7 & 17.7 & 18.8 \\ 20 & 19.8 & 20.9 & 21.9 & 22.9 & 23.9 & 25.0 & 26.0 & 27.0 & 28.0 & 29.0 \\ 30 & 30.1 & 31.1 & 32.1 & 33.1 & 34.2 & 35.2 & 36.2 & 37.1 & 38.1 & 39.1 \\ 40 & 40.1 & 41.1 & 42.1 & 43.1 & 44.1 & 45.0 & 46.0 & 47.0 & 47.9 & 48.9 \\ & & & & & & & & & & \\ 50 & 49.8 & 50.7 & 51.7 & 52.6 & 53.6 & 54.5 & 55.4 & 56.3 & 57.3 & 58.2 \\ 60 & 59.1 & 60.0 & 60.9 & 61.9 & 62.8 & 63.7 & 64.6 & 65.5 & 66.5 & 67.4 \\ 70 & 68.3 & 69.2 & 70.1 & 71.0 & 72.0 & 72.9 & 73.8 & 74.7 & 75.6 & 76.6 \\ 80 & 77.5 & 78.4 & 79.3 & 80.2 & 81.1 & 82.0 & 83.0 & 83.9 & 84.8 & 95.7 \\ 90 & 86.6 & 87.6 & 88.5 & 89.4 & 90.3 & 91.3 & 92.2 & 93.1 & 94.0 & 95.0\end{array}$

$\begin{array}{lllllllllll}95.9 & 96.8 & 97.7 & 98.7 & 99.6 & 100.5 & 101.4 & 102.4 & 103.3 & 104.2\end{array}$

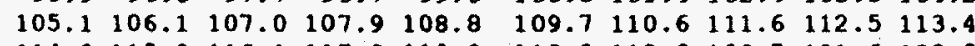

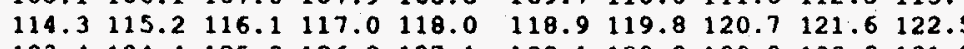

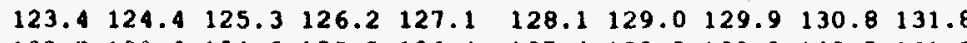
$\begin{array}{llllllllll}132.7 & 133.6 & 134.6 & 135.5 & 136.4 & 137.4 & 138.3 & 139.3 & 140.2 & 141.2\end{array}$

$\begin{array}{llllllllll}142.1 & 143.0 & 144.0 & 144.9 & 145.9 & 146.8 & 147.8 & 148.7 & 149.7 & 150.6\end{array}$ $\begin{array}{lllllllllll}151.6 & 152.5 & 153.5 & 154.4 & 155.4 & 156.3 & 157.3 & 158.2 & 159.2 & 160.1\end{array}$ $\begin{array}{lllllllllll}161.1 & 162.0 & 163.0 & 164.0 & 164.9 & 165.9 & 166.8 & 167.8 & 168.7 & 169.7\end{array}$

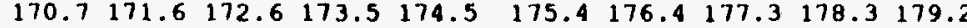
$\begin{array}{llllllllll}180.2 & 181.1 & 182.1 & 183.0 & 184.0 & 184.9 & 185.9 & 186.8 & 187.8 & 188.7\end{array}$

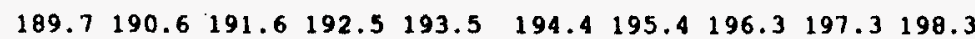
$199.2200 .2201 .1202 .1203 .1 \quad 204.0 \quad 205.0206 .0206 .9207 .9$ 208.9209 .9210 .8211 .8212 .8213 .8214 .7215 .7216 .7217 .7 218.7219 .7220 .7221 .7222 .7213 .8214 .7215 .7216 .7217 .7 $\begin{array}{lllllllllll}228.8 & 229.8 & 230.8 & 231.8 & 232.8 & 233.8 & 234.9 & 235.9 & 236.9 & 237.9\end{array}$

$238.9239 .9241 .0242 .0243 .0 \quad 244.0245 .0246 .0247 .0248 .0$ $248.9249 .9250 .9251 .9252 .9 \quad 253.9254 .9255 .8 \quad 256.8 \quad 257.8$

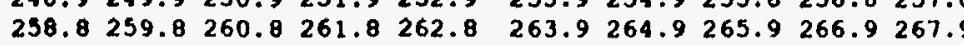
$268.9269 .9270 .9272 .0273 .0 \quad 274.0 \quad 275.0276 .0 \quad 277.0 \quad 278.0$ $279.0280 .0281 .0282 .0283 .0 \quad 284.0285 .0286 .0287 .0$

?

0

$\begin{array}{rrrrrr}0 & -5.7 & -4.5 & -3.4 & -2.3 & -1.1 \\ 10 & 5.7 & 6.8 & 7.9 & 9.1 & 10.2 \\ 20 & 17.0 & 18.1 & 19.2 & 20.4 & 21.5\end{array}$

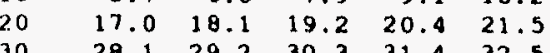

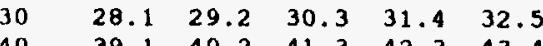

$\begin{array}{llllll}50 & 49.9 & 51.0 & 52.1 & 53.1 & 54.2\end{array}$

$60 \quad 60.5 \quad 61.5 \quad 62.6 \quad 63.6 \quad 64.6$

$\begin{array}{llllll}70 & 70.8 & 71.8 & 72.8 & 73.9 & 74.9\end{array}$

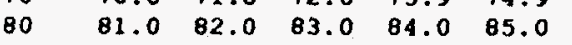

$\begin{array}{llllll}90 & 91.0 & 82.0 & 83.0 & 84.0 & 85.0 \\ & 91.1 & 92.1 & 93.2 & 94.2 & 95.2\end{array}$

100

110

120

130

150

150

160

180

190

101.4102 .4103 .4104 .4105 .5 $111.7112 .7 \quad 113.7114 .7115 .8$ $\begin{array}{lllll}122.0 & 123.0 & 124.1 & 125.1 & 126.1\end{array}$ 142.9143 .9145 .0146 .0147 .1

$153.4 \quad 154.5 \quad 155.6 \quad 156.6 \quad 157.7$ $164.2165 .2 \quad 166.3 \quad 167.4168 .5$ $\begin{array}{lllll}175.0 & 176.1 & 177.2 & 178.3 & 179.3\end{array}$ $186.9187 .0 \quad 188.0189 .1 \quad 190.2$

207.6208 .7209 .8210 .9212 .0

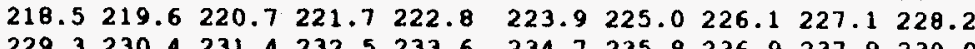
$240.1241 .4231 .4232 .5233 .6 \quad 234.7235 .8 \quad 236.9237 .9239 .0$ 251.0252 .1253 .3243 .4244 .5245 .5246 .6247 .7248 .8249 .9 $\begin{array}{llllllll}253.2 & 254.3 & 255.4 & 256.4 & 257.5 & 258.6 & 259.8 & 260.9\end{array}$

$262.0263 .1264 .2265 .3266 .5 \quad 267.6268 .7269 .9271 .0272 .1$ $273.3274 .4275 .6 \quad 276.7277 .8 \quad 279.0 \quad 280.1281 .2 \quad 282.4283 .5$ $284.6285 .7286 .9288 .0289 .1 \quad 290.3291 .4292 .5 \quad 293.7294 .8$

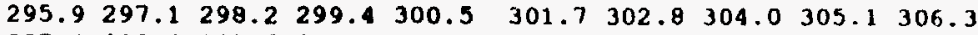
$307.4308 .6309 .7310 .8312 .0 \quad 313.1$ 
$07.45: 302.5602 .6010$

$07: 45: 302.5602 .601$ CD $51.20 \quad 60.50 \quad 51.2 \quad 61.6$

$07: 46: 002.5592 .591$ D

$07: 47: 00 \quad 2.5402 .572$ A $168.40 \quad 166.70 \quad 157.3 \quad 171.4 \quad-14.1$

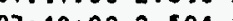

$07: 49: 002.5042 .533 \mathrm{C}$

$07: 50: 00 \quad 2.486 \quad 2.515$ D $\quad 49.60 \quad 58.90 \quad 49.7 \quad 60.0$

$07: 50: 302.4772 .506$ AD

$07: 51: 00 \quad 2.468 \quad 2.497$ \& $163.90 \quad 162.60 \quad 152.9 \quad 167.0 \quad-14.1$

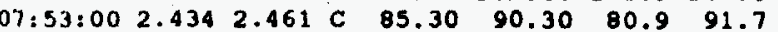

$07: 53: 302.426 \quad 2.452 \mathrm{CD}$

07:54:00 $2.417 \quad 2.444$ D $\quad 48.30 \quad 57.30 \quad 48.5 \quad 58.3$

$07: 54: 302.4092 .435$ AD

07:55:00 2.401 2.427 A $159.20 \quad 158.30148 .3 \quad 162.3 \quad-14.1$

$07: 57: 002.3692 .393$ C $\quad 83.00 \quad 88.00 \quad 78.8 \quad 89.4$

$07: 57: 302.3612 .385 \mathrm{CD}$

07:58:00 $2.353 \quad 2.377$ D $\quad 46.70 \quad 56.20 \quad 47.0 \quad 57.1$

$07: 58: 30 \quad 2.345 \quad 2.369$ AD

07:59:00 2.338 2.361 A $155.10 \quad 144.3$

$\begin{array}{llllllll}08: 15: 00 & 2.120 & 2.136 & C & 73.70 & 79.70 & 70.3 & 81.0\end{array}$

$08: 15: 302.1142 .130 \mathrm{CD}$

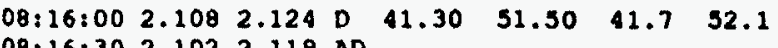

$08: 16: 302.102 \quad 2.118 \quad A D$

$09: 17: 002.0962 .111 \times 138.90 \quad 140.10 \quad 128.6143 .0 \quad-14.3$

$08: 19: 00 \quad 2.073 \quad 2.088$ C $72.10 \quad 78.00 \quad 68.8 \quad 79.3$

$08: 19: 302.0672 .082 \mathrm{CD}$

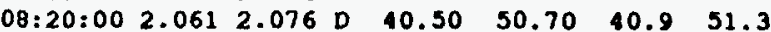

$0 B: 20.302 .056 \quad 2.070$ aD

$08: 21: 00 \quad 2.050 \quad 2.064$ A $136.20 \quad 137.30 \quad 126.1 \quad 140.0 \quad-13.9$

08.23 .002 .0202 .042070 .3076 .60167 .1277 .9

$08: 23: 302.0232 .036 \mathrm{CD}$

08:24:00 $2.018 \quad 2.031$ D $39.80 \quad 50.00 \quad 40.3 \quad 50.5$

$08: 24: 302.012 \quad 2.026$ AD

OB:23:00 2.007 2.020 A $133.50 \quad 134.80 \quad 123.5 \quad 137.4 \quad-13.9$

$08: 27: 001.9861 .999 \mathrm{C}$

$\begin{array}{llllllll}08: 27: 30 & 1.981 & 1.994 & C D & & & & \\ 08: 28: 00 & 1.976 & 1.988 & D & 38.80 & 49.20 & 39.3 & 49.7\end{array}$

$08: 28: 301.971 \quad 1.983$ AD

$08: 29: 00 \quad 1.966 \quad 1.978$ A $131.00 \quad 132.20121 .1 \quad 134.7 \quad-13.5$

$08: 31: 00 \quad 1.946 \quad 1.958$ C $67.30 \quad 73.90 \quad 64.4 \quad 75.2$

$08: 31: 301.9421 .953 \mathrm{CD}$

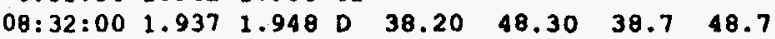

$08: 32: 301.932 \quad 1.943$ AD

$08: 33: 00 \quad 1.927 \quad 1.938$ A $128.20129 .80118 .5 \quad 132.1 \quad-13.6$

08:35:00 1.909 1.919 C $66.20 \quad 72.50 \quad 63.4 \quad 73.8-13.6$

$O B: 35: 301.9041 .915 \mathrm{CD}$

$08: 36: 00 \quad 1.899 \quad 1.910 \quad 0 \quad 37.30 \quad 47.90 \quad 37.8 \quad 48.3$

$08: 36: 301.8951 .905$ AD

$08: 37: 00 \quad 1.890 \quad 1.901$ A $125.90 \quad 127.70 \quad 116.3 \quad 130.0 \quad-13.6$ $08: 39: 00 \quad 1.873 \quad 1.883 \mathrm{C}$ $08: 39: 301.868 \quad 1.878 \mathrm{CD}$

$08: 40: 00 \quad 1.864 \quad 1.874$ D $37.30 \quad 47.20 \quad 37.8 \quad 47.3$

$08: 40: 301.860,1.869$ AD

$124.00125 .80114 .6 \quad 128.0-13.4$

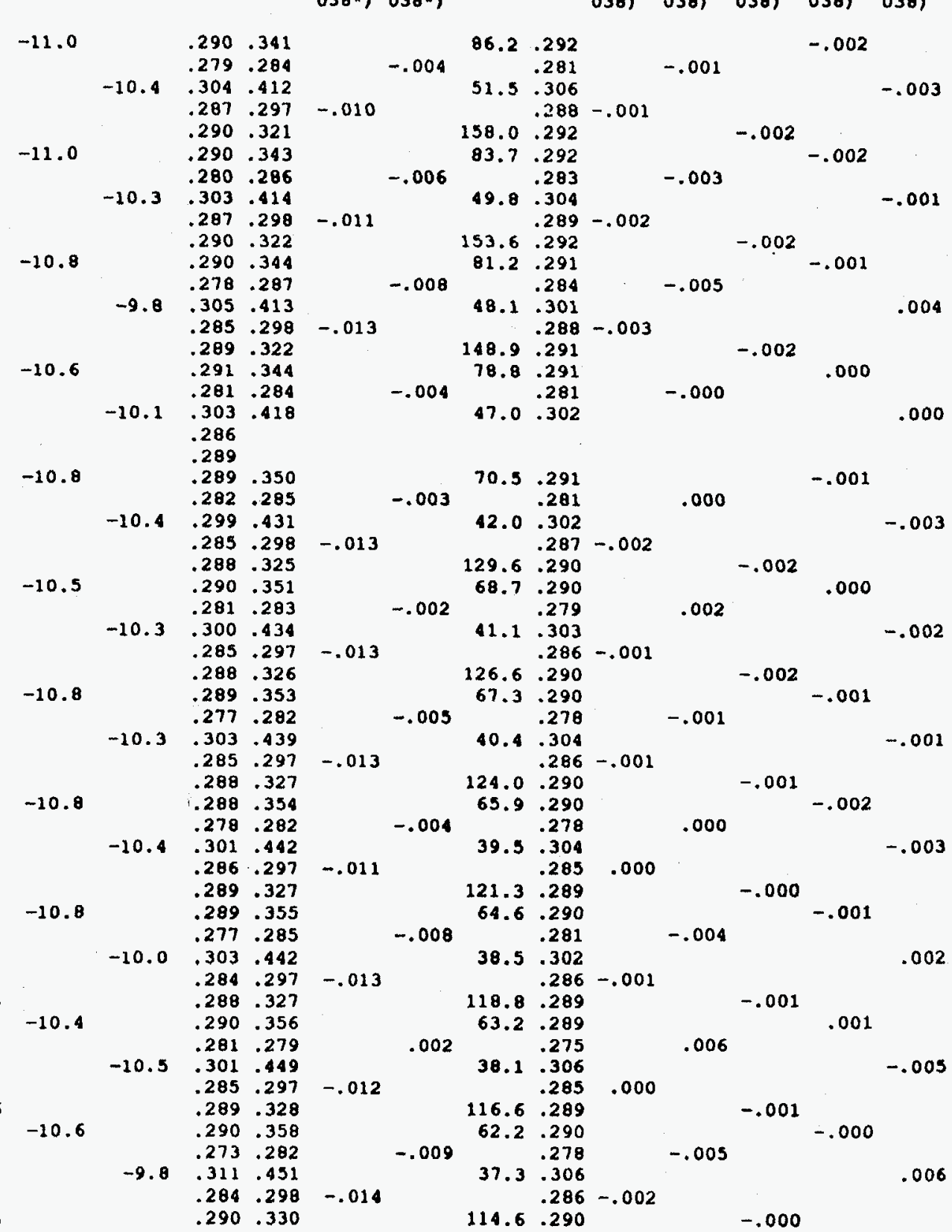

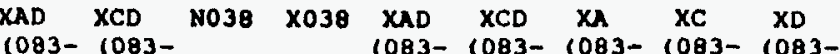
$(083-(083-$

$08: 41: 001.856 \quad 1.865$ A $124.00125 .80114 .6129 .0-13.4$ 


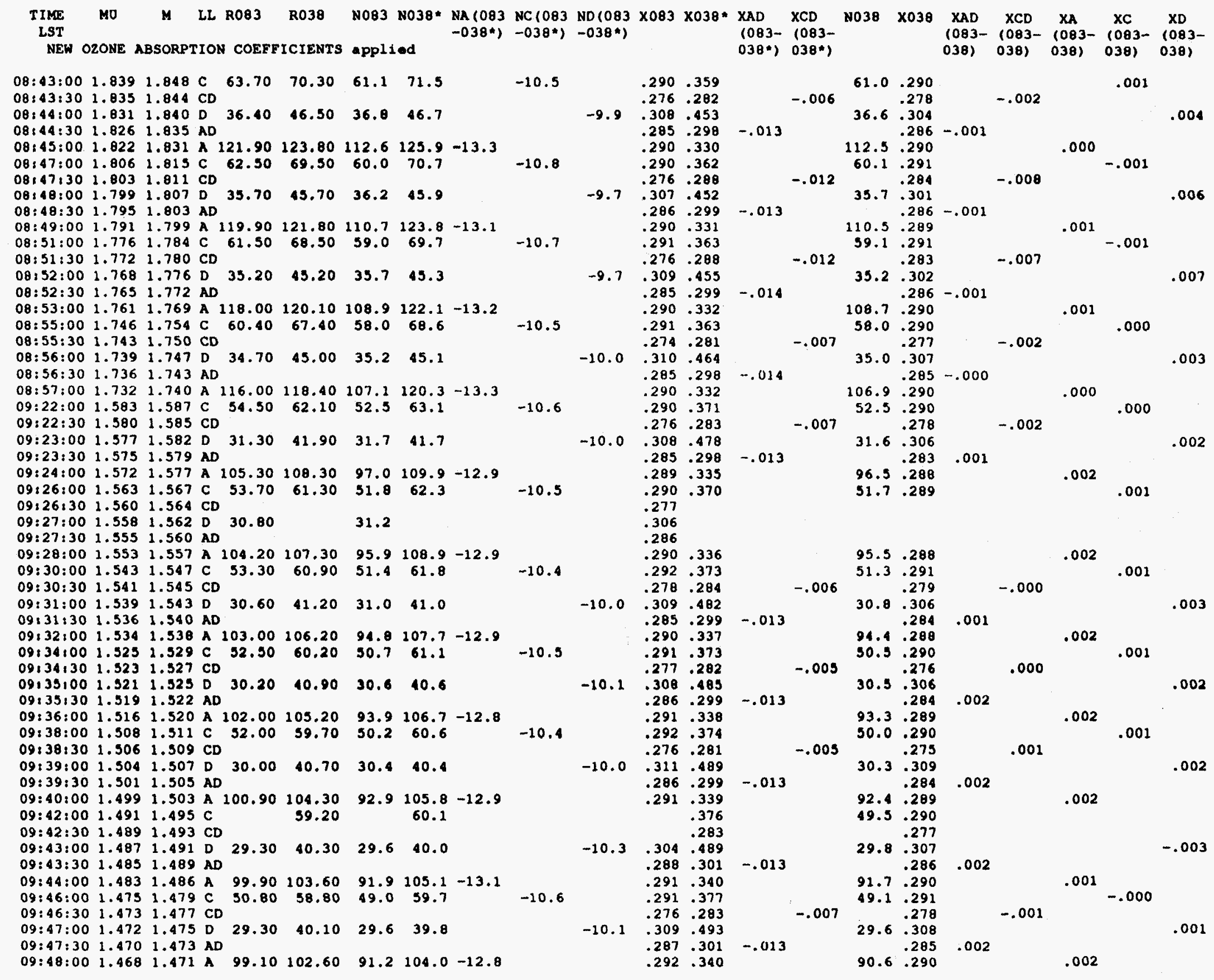



$09.50 .301 .4501 .463 \mathrm{C}$

$09.51 .001 .4571 .461 \mathrm{CD} 29.00 \quad 40.00 \quad 29.4 \quad 39.6$ $09: 51: 301.4551 .458$ AD

$09: 52: 001.4531 .456$ A $98.10 \quad 101.90 \quad 90.3 \quad 103.3 \quad-13.1$

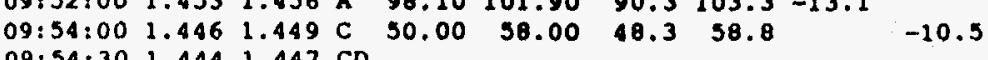

$09: 55: 001.443 \quad 1.445$ D $28.50 \quad 39.70 \quad 28.8 \quad 39.3$

$09: 55: 301.441 \quad 1.444$ AD

$09: 56: 00 \quad 1.4391 .442$ A $97.20 \quad 101.00 \quad 89.4 \quad 102.4 \quad-13.0$

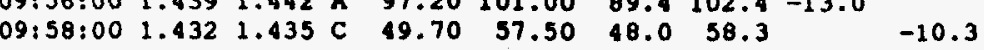

$09: 58: 301.4311 .433 \mathrm{CD}$

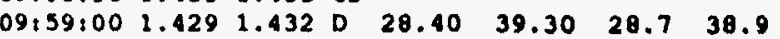

$09: 59: 301.427 \quad 1.430 \mathrm{AD}$

$10: 00: 00 \quad 1.4261 .428$ A $96.20 \quad 100.00 \quad 88.5 \quad 101.3 \quad 12.9$

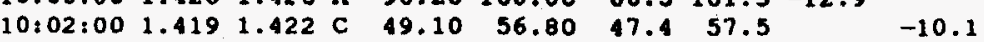

$10: 02: 301.4181 .420 \mathrm{CD}$

10:03:00 $1.416 \quad 1.419 \mathrm{D} \quad 28.20 \quad 39.20 \quad 28.5 \quad 38.8$

$10: 03: 301.4151 .417 \mathrm{AD}$

10:04:00 $1.413 \quad 1.416$ A $95.20 \quad 99.30 \quad 87.5 \quad 100.6 \quad-13.1$

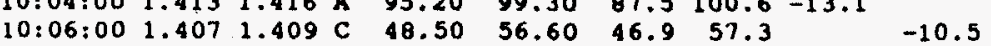

$10: 06: 30 \quad 1.405 \quad 1.408 \mathrm{CD}$

$\begin{array}{llllllll}10: 07: 00 & 1.404 & 1.406 & D & 27.90 & 39.10 & 28.2 & 38.7\end{array}$

$\begin{array}{llllllll}10: 07: 30 & 1.403 & 1.405 & \text { AD } & & & & \\ 10: 08: 00 & 1.401 & 1.403 & \text { A } 94.20 & 98.50 & 86.6 & 99.8 & -13.2\end{array}$

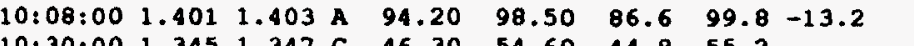

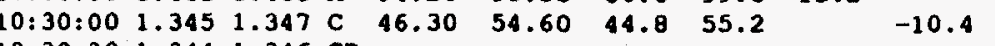

$10: 30: 301.344 \quad 1.346 \mathrm{CD}$

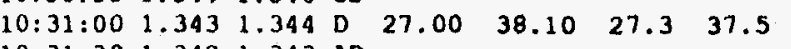

$10: 31: 301.342 \quad 1.343 \mathrm{AD}$

10:32:00 $1.341 \quad 1.342$ A $90.50 \quad 95.20 \quad 83.1 \quad 96.4-13.3$

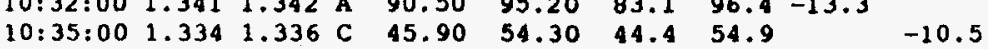

$10: 35: 301.3331 .335 \mathrm{CD}$

10:36:00 $1.332 \quad \begin{array}{llllll}1.334 & \mathrm{D} & 26.80 & 38.00 & 27.1 & 37.4\end{array}$

$10: 36: 30 \quad 1.331 \quad 1.333 \mathrm{AD}$

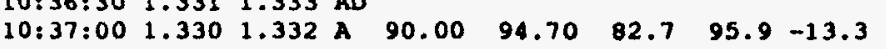

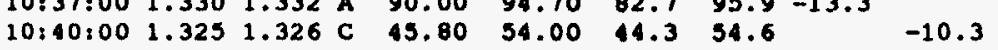

$10: 40: 301.324 \quad 1.325 \mathrm{CD}$

$10: 41,001.323 \quad 1.324$ D $26.60 \quad 37.70 \quad 26.9 \quad 37.1$

$10: 41: 301.3221 .323$ AD

$10: 42: 001.321 \quad 1.322$ A $89.40 \quad 93.80 \quad 82.1 \quad 93.0-12.9$

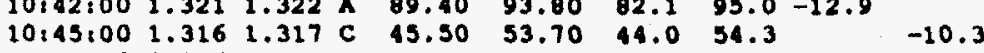

$10: 45: 301.3151 .316 \mathrm{CD}$

10:46:00 $1.314 \quad 1.315$ D $26.70 \quad 37.80 \quad 27.0 \quad 37.2$

$10: 46: 301.3131 .314$ AD

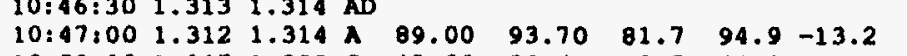

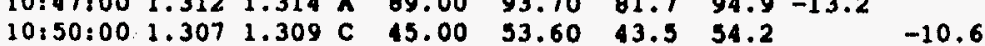

$10: 50: 301.306 \quad 1.308 \mathrm{CD}$

10:51:00 $1.306 \quad 1.307$ D $26.20 \quad 37.50 \quad 26.5 \quad 36.9$

10:51:00 1.306 1.307 D

$\begin{array}{lllllll}10: 51: 30 & 1.305 & 1.306 \text { AD } & & & & \\ 10: 52: 00 & 1.304 & 1.305 \text { A } 88.00 & 93.00 & 80.8 & 94.2 & -13.4\end{array}$

$10: 52: 001.304 \quad 1.305$ A $88.00 \quad 93.00 \quad 80.8 \quad 94.2 \quad-13.4$

$10: 55: 00 \quad 1.300 \quad 1.301 \mathrm{C}$

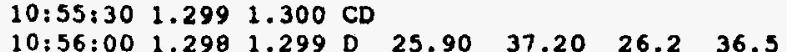

10:56:00 $1.2981 .299 \mathrm{D}$

$\begin{array}{llllllll}10: 56: 30 & 1.297 & 1.299 & A D & & & & \\ 10: 57: 00 & 1.297 & 1.298 \text { A } & 07.70 & 92.80 & 80.5 & 94.0 & -13.5\end{array}$

$X A D \quad X C D \quad X A \quad X C \quad X D$ $\begin{array}{ll}\text { XAD } & \text { XCD } \\ (083- & (083-\end{array}$ $\left.038^{\circ}\right)$ (038") 038) 038) 038) 038) 038)

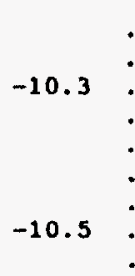

278.280

.309 .498

.287 .301

.292 .342

.283 .283

$\begin{array}{rr}.283 & .283 \\ 305 & .499\end{array}$

.288
.292 .301
.342

.294 .381

.283 .285

$-10.1 .308 .498$

.287 .301

.292 .342

.293 .379

$-10.2$ 280.278

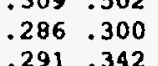

$\begin{array}{rr}.291 & .342 \\ .292 & .381\end{array}$

.292 .381

$\begin{array}{rrr} & .279 & .279 \\ -10.4 \quad .308 & .507\end{array}$

.285 .299

$\begin{array}{rr}.290 & .342 \\ .292 & .385\end{array}$

$\begin{array}{ll}.292 & .385 \\ .273 & .276\end{array}$

$-10.2 \quad .315 \quad .519$

.285 .301

.291 .346

.292 .386

.273 .275

$-10.3$

.315 .522

.286 .301

.292
.294
.347
.2787

.277 .278

$-10.2 \quad .315 .521$

$.286 \cdot 301$

.294 .387

.272 .273

$-10.2 \quad .320 \quad .52$
.586

.286 .301

.293 .348

.292 .390

.274 .278

$\begin{array}{lll}-10.4 & .313 & .526\end{array}$

$\begin{array}{lll}.2713 & .526 & \\ .285 & .301 & -.016\end{array}$

.292 .390

.292 .390

$\begin{array}{rrr}-10.4 & .310 & .280 \\ & .328 & .524\end{array}$

.287 .304

.287 .304
$48.5 \quad 291$

$\begin{array}{lll}-.002 & 40.5 & .291 \\ & & .274 \\ & 29.5 & .312\end{array}$

89.9 .285
.291

48.2 .293
$.000 \quad 8.271$

.277
29.2 .311

.285
.285

89.0 .290

$47.7 \quad .292$

$-.002$

$-.014$

28.7 .308

88.0 .290

.002

$\begin{array}{ll}28.6 & .272 \\ & .311\end{array}$

.014

$28.6 \cdot 311$

87.2 .290

$-.000$

46.8 .291

$28.5 \quad .313$

$\begin{array}{lr}.014 \quad 0.283 \\ & 06.4 .290\end{array}$

$\begin{array}{lr}86.4 & .290 \\ 44.6 & .291\end{array}$

$-.003$

$27.4 \begin{array}{r}.270 \\ .316\end{array}$

$-.016$

$83.0 \quad .284$

$-.002$

$-.015$

44.3 .291

$27.3 \begin{array}{r}.269 \\ .318\end{array}$

$82.5 \quad .284$

44.0 .291

$-.001$

$-.014$

27.0 .316

81.6 .290

$81.6 \quad .290$
43.7 .291

$-.000$

27.1 .322

$81.5 \quad .292$

43.6 .292

$-.004$

$26.7 \quad .271$

$26.7 \cdot 318$

80.8 .291

$\begin{array}{ll}80.8 & .291 \\ 4.292\end{array}$

$-.002$

$\begin{array}{rr} & .273 \\ 26.4 & .315\end{array}$

$-.017$

$\begin{array}{rr}60.6 & .286 \\ 6.292\end{array}$
.001

$-.002$

002

.004

.001

.006

.000

004

006

$-.006$

.002

.004

.003

.00

.002

(2)

.002

.006

$$
-.005
$$

001

.001

$-.002$

.001

.004

.000

.001

.002

.004

.001

.006

.003

.001

.003

$-.001$

.002

.006

.003

$-.001$

.001

.001

$-.001$

.001

.003

.001

$-.005$

.001

.005

$-.004$

$-.000$ 


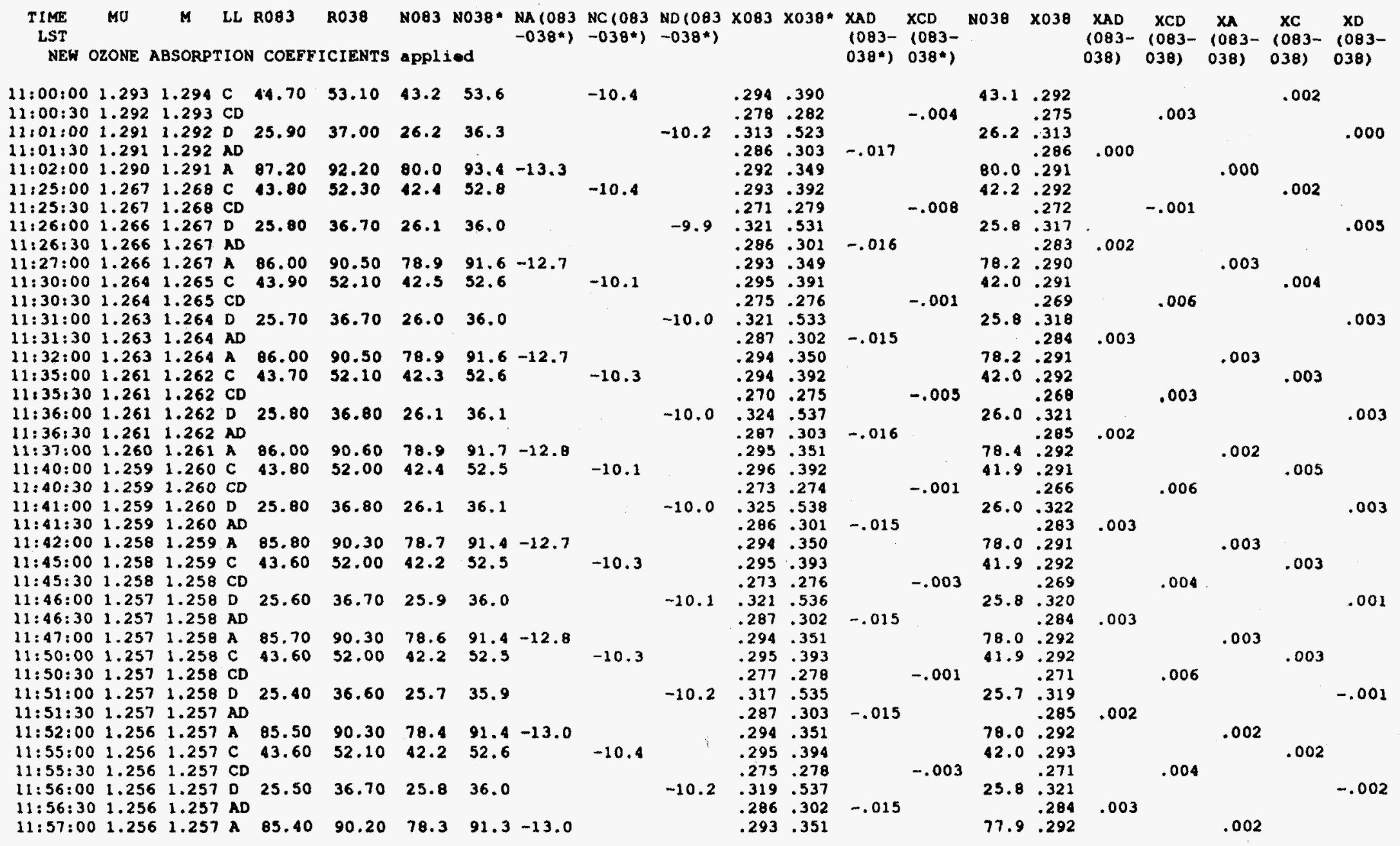


PLOT OF NA/MU FOR INST. 83 September 16, 1991 AM

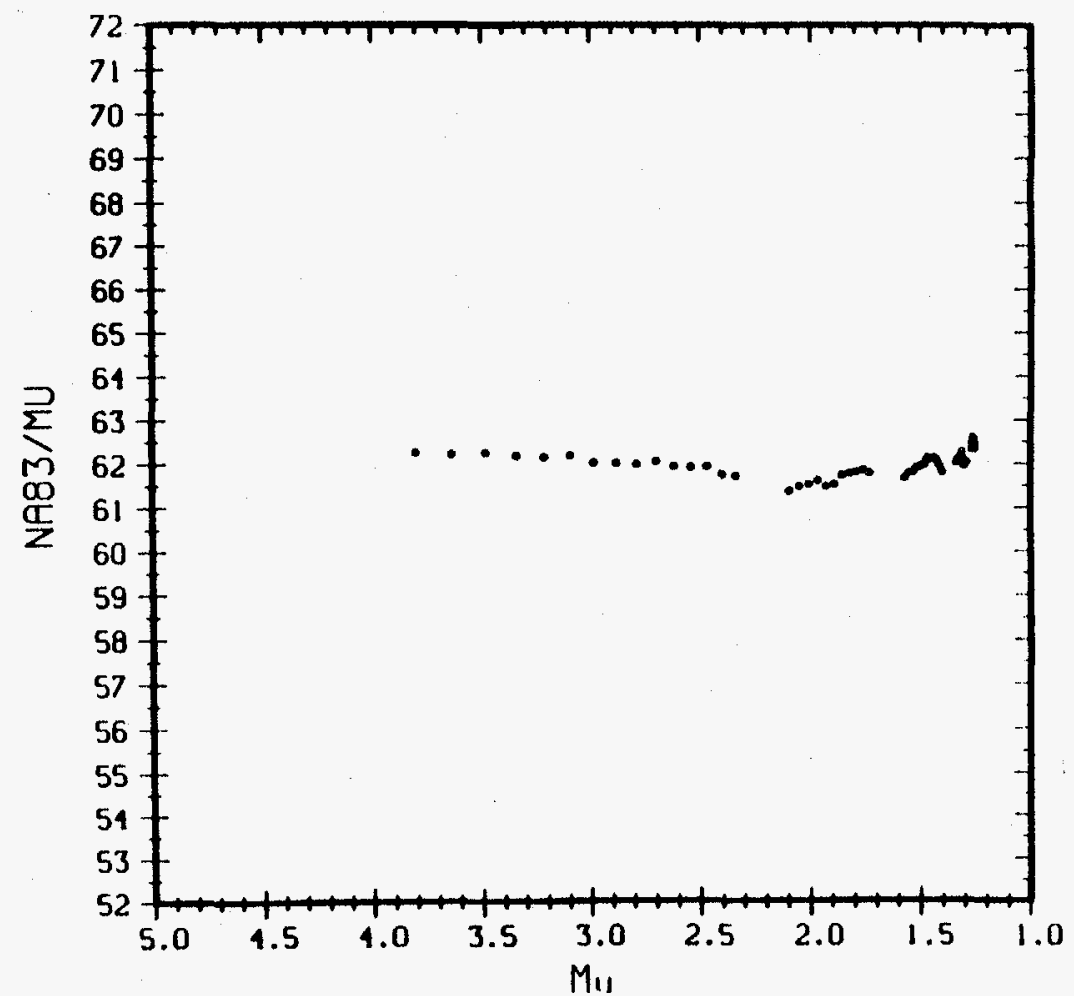

PLOT OF NA/MU FOR INST. 38 September 16, 1991 AM

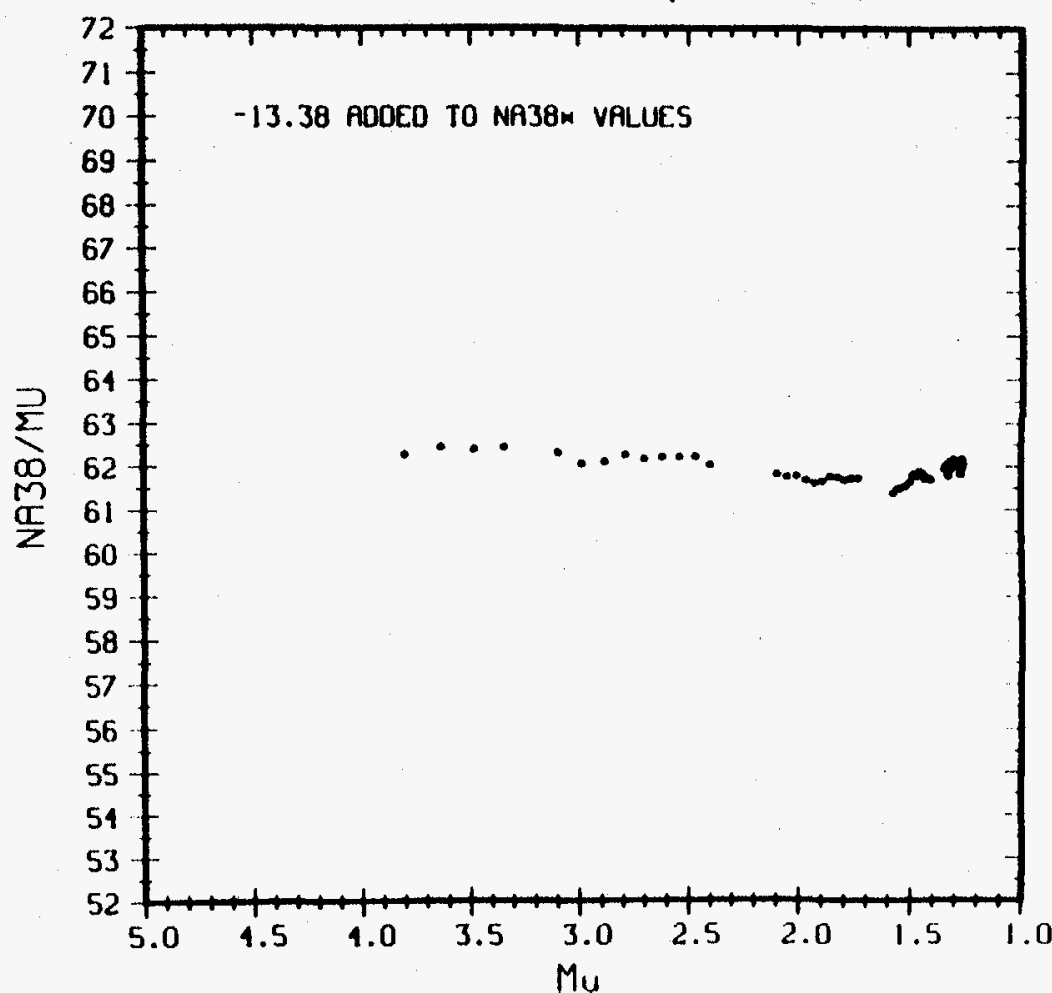




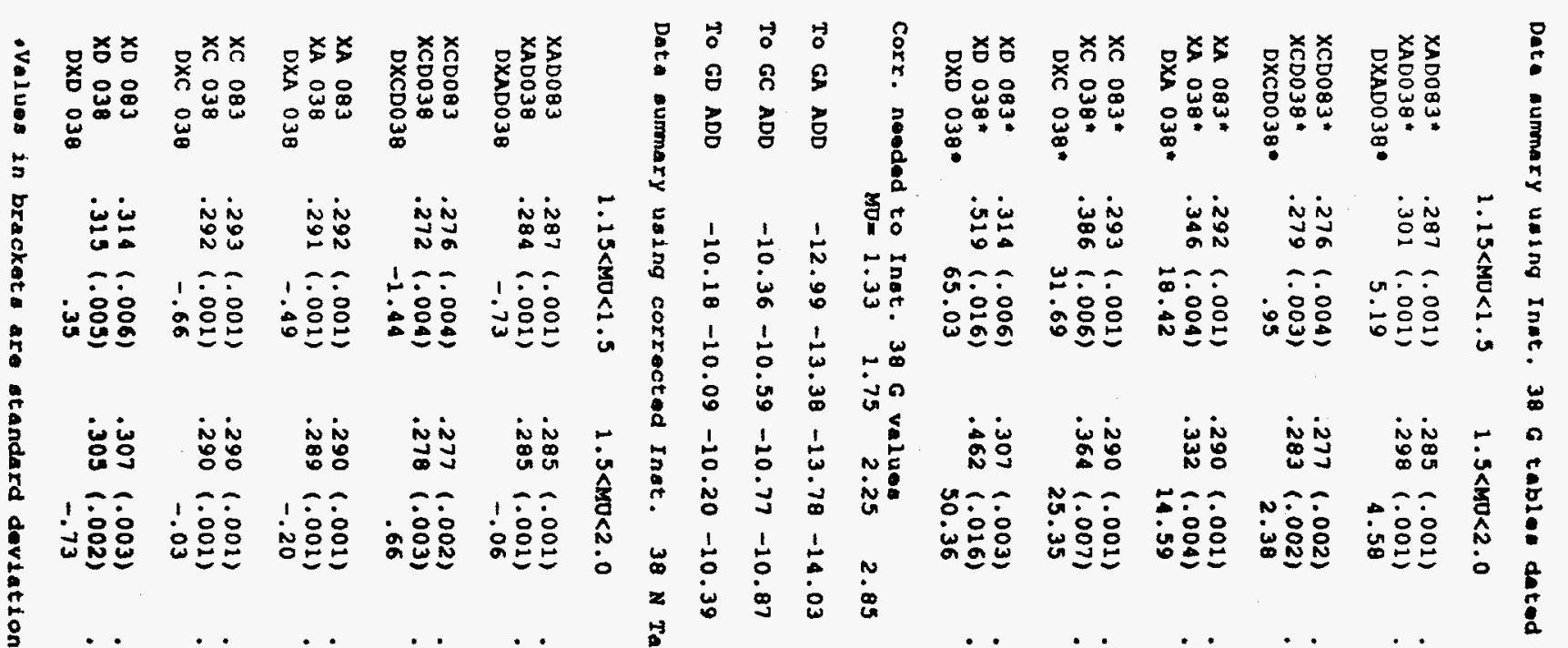

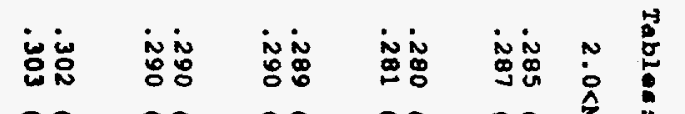

च N

¿ 造 i i

罴

家

流定

聏 $\frac{0}{3}$

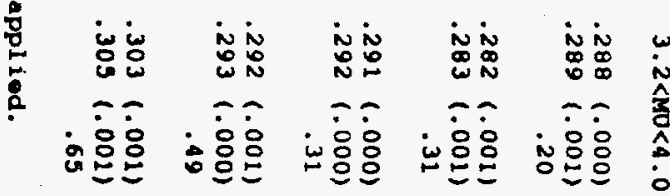

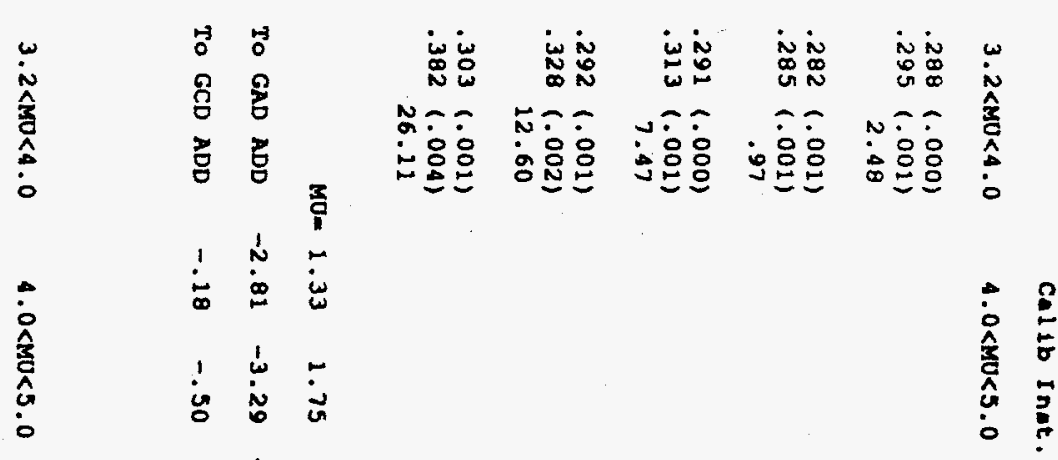

$1+\frac{1}{d} N$

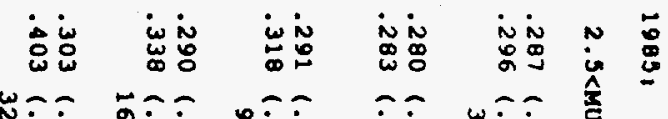
我

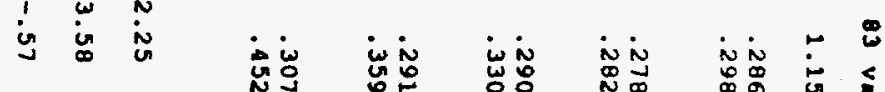

ن

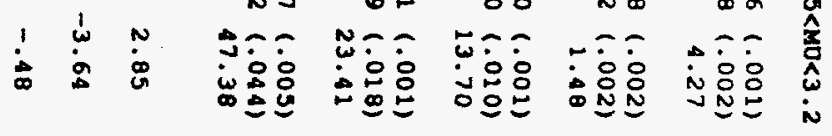

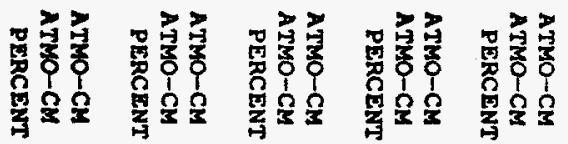

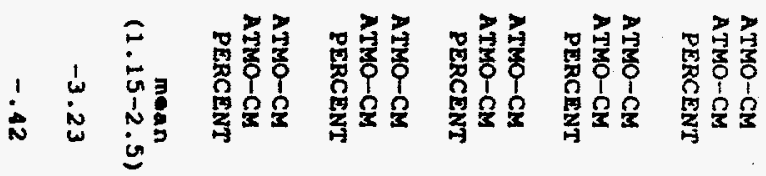

Cuble oquations for $\mathrm{N}$-function corrections to inst. $38 \mathrm{G}$-Tables

A $\quad-.1239049798 E+02 \quad .2761865421 E+00-.7739192339 \mathrm{E}+00 \quad .1663949771 E+00$

$\begin{array}{llll}-.9069637924 E+01 & -.1315039051 E+01 & .2775152775 E+00 & -.1306656505 E-01\end{array}$

$\begin{array}{llll}-.1291069738 E+02 & .4064059824 E+01 & -.2852988320 E+01 & .2587008659 E+00\end{array}$ 
PLOT OF NC/MU FOR INST. 83 September 16, 1991 AM

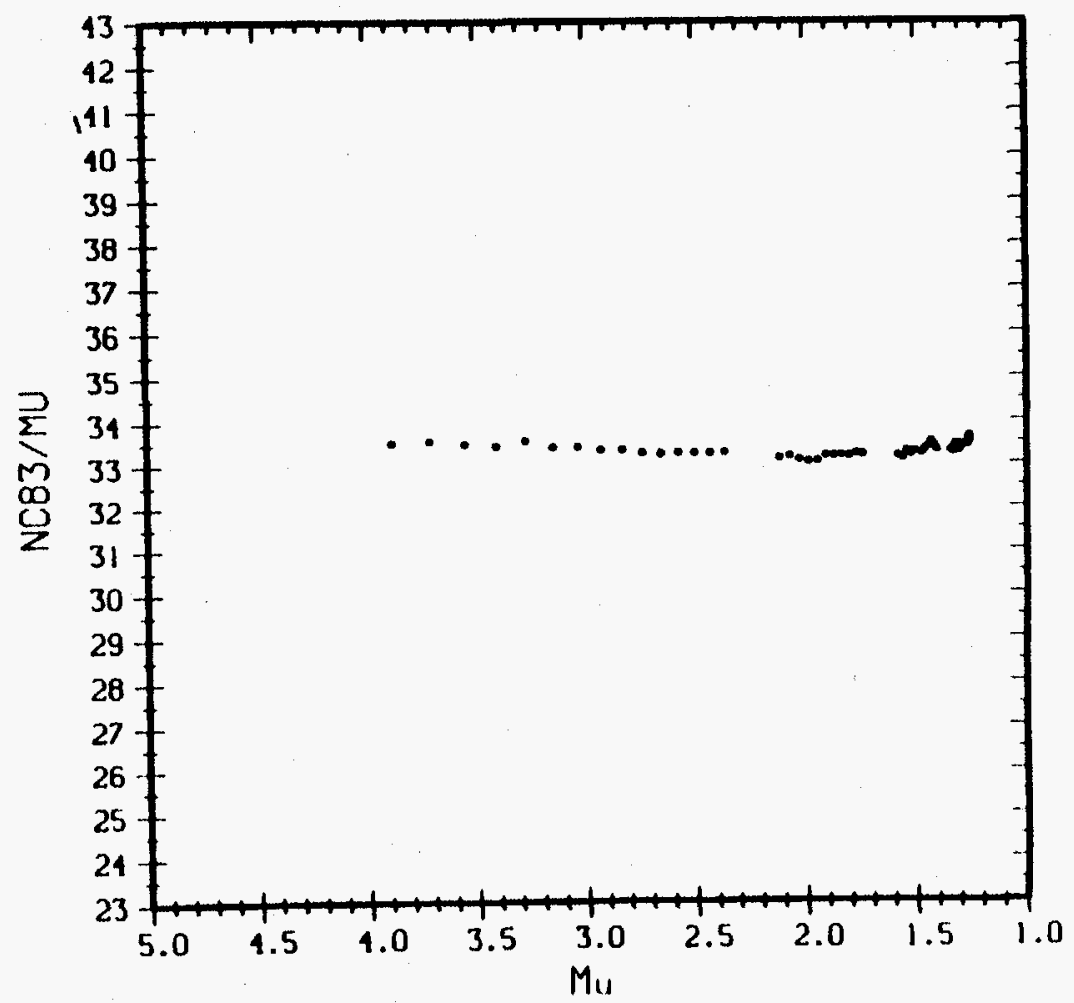

PLOT OF NC/MU FOR INST. 38 September 16, 1991 AM

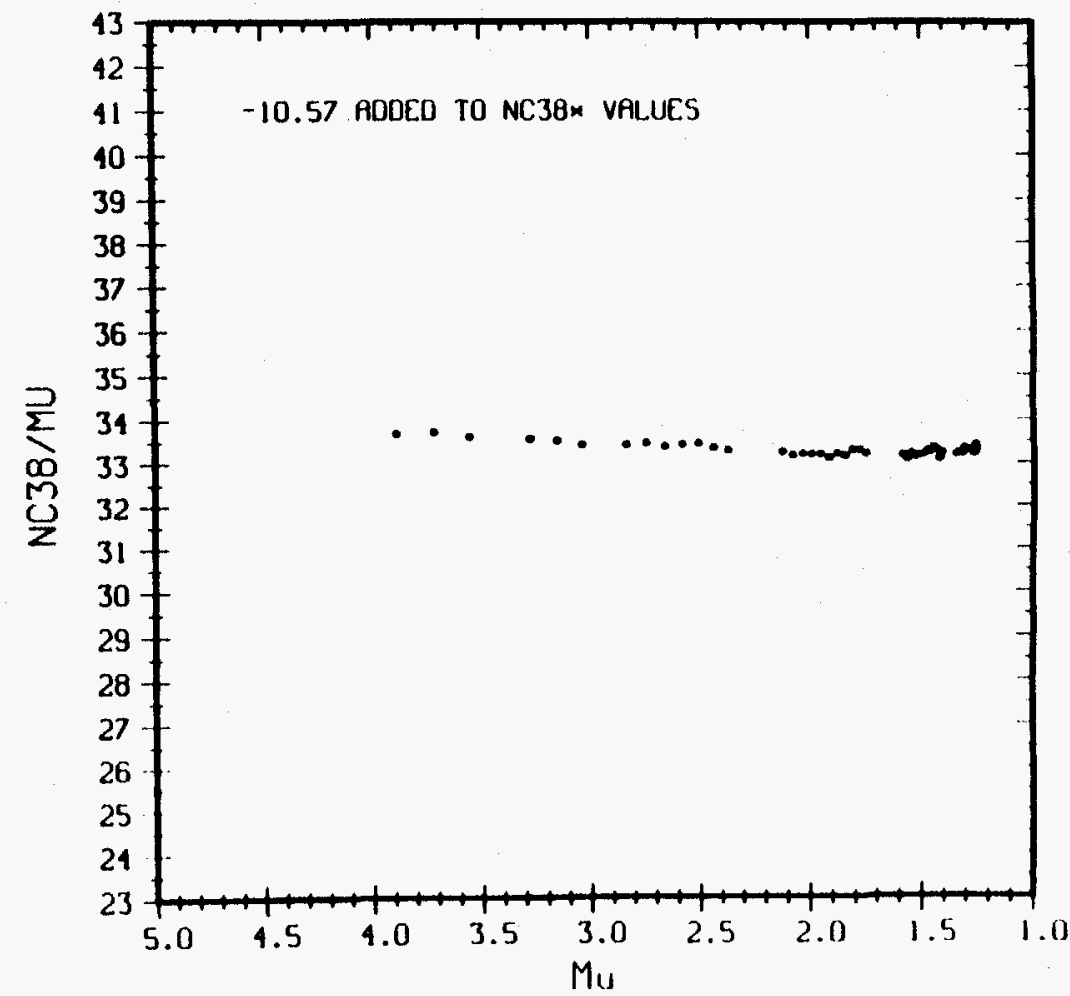




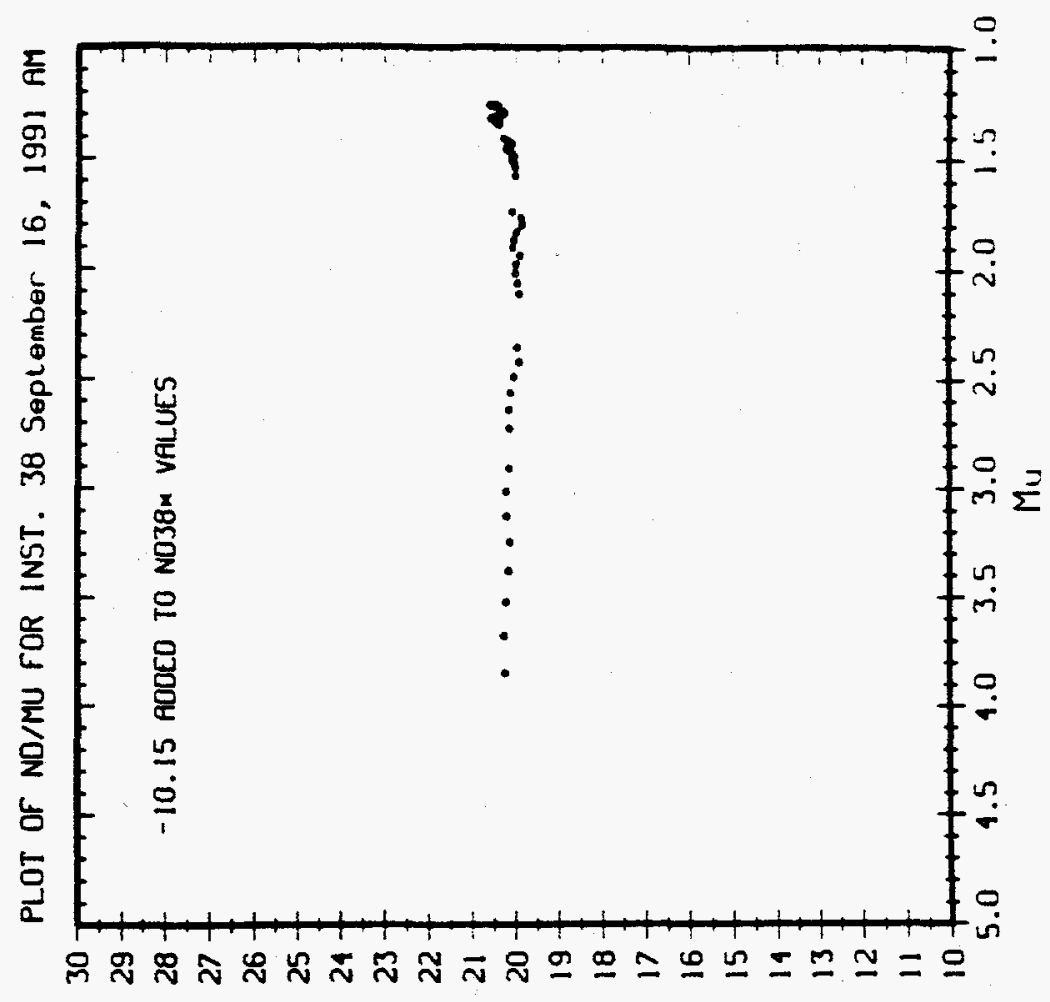

SW/BEON

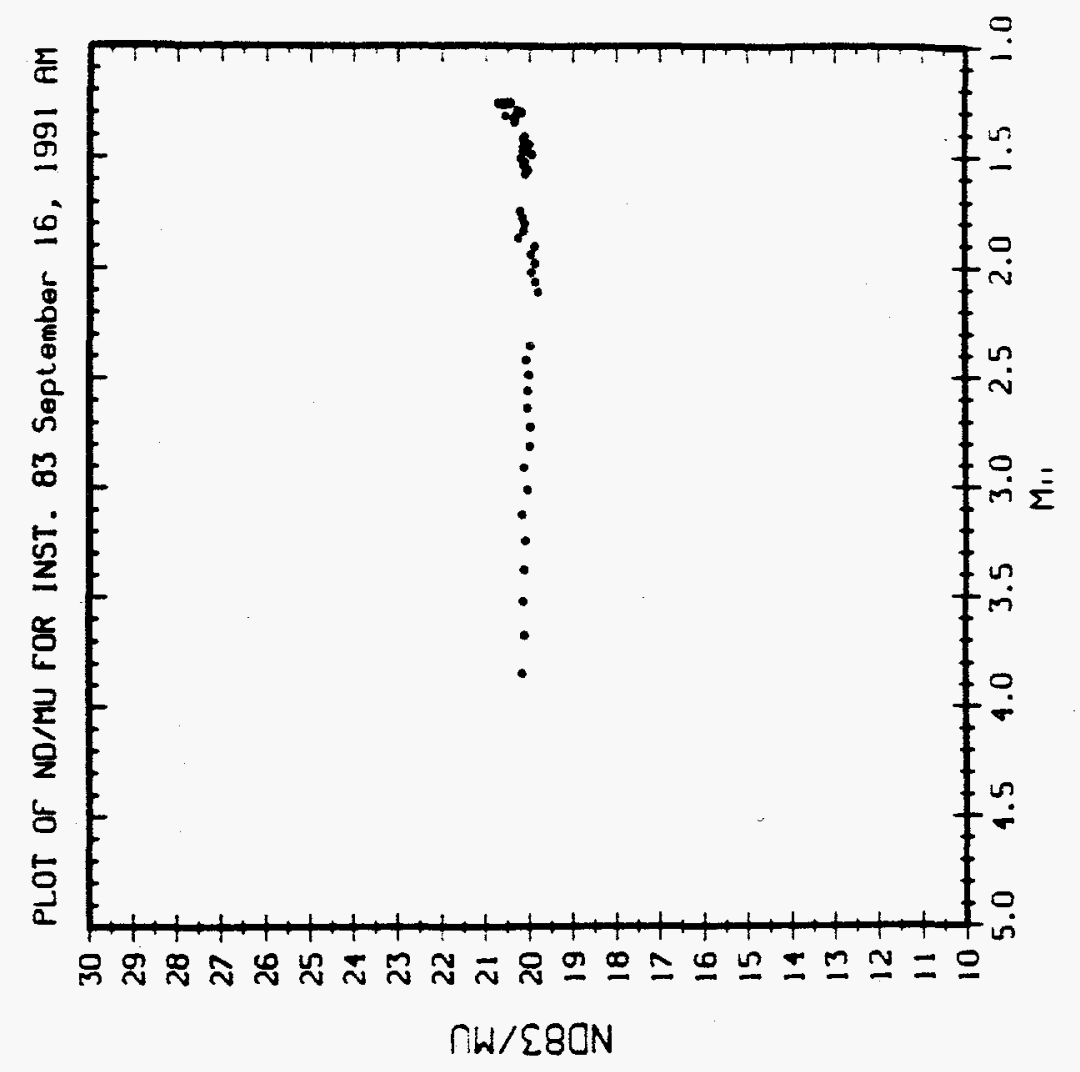



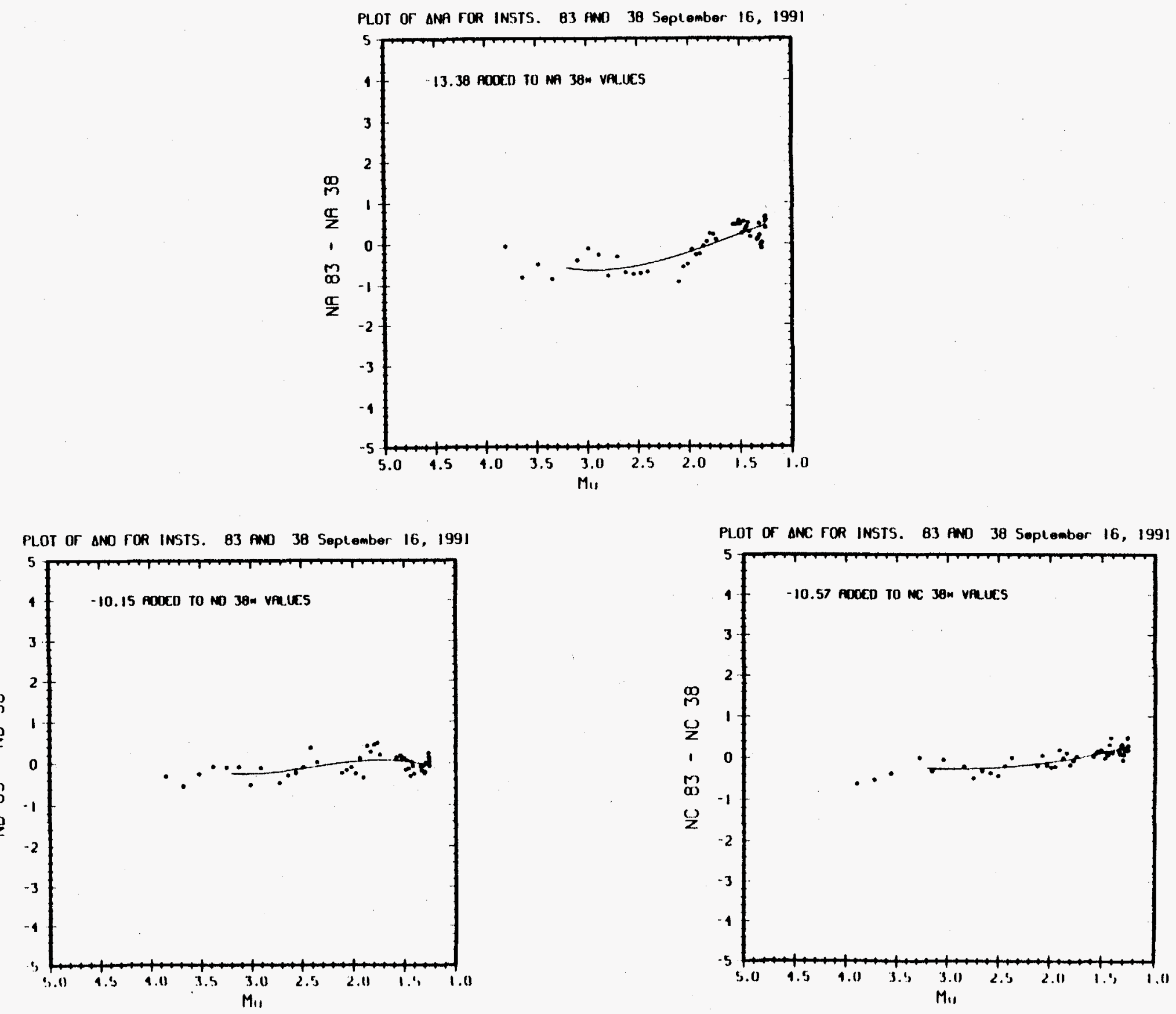

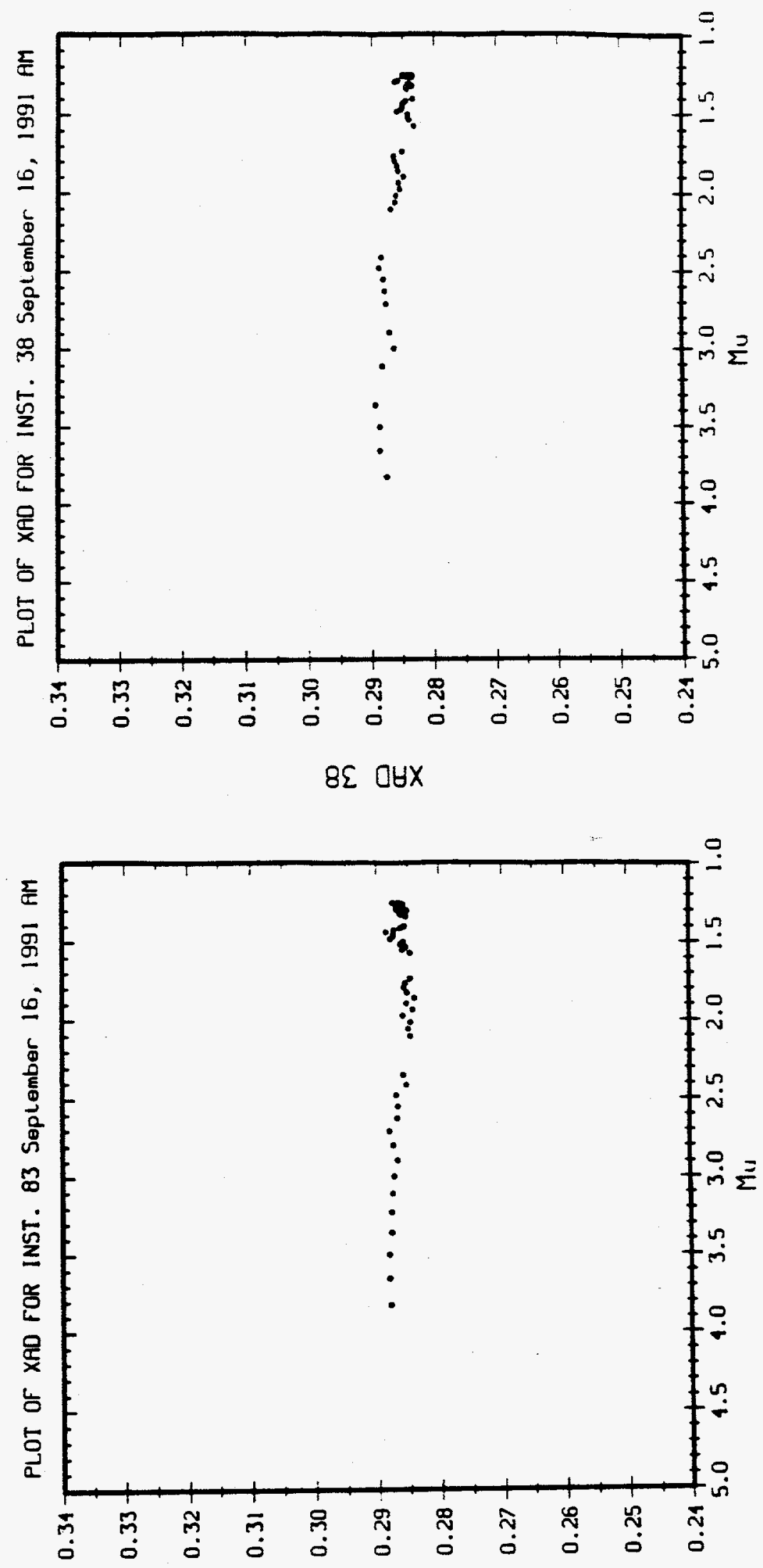

E8 OUX 

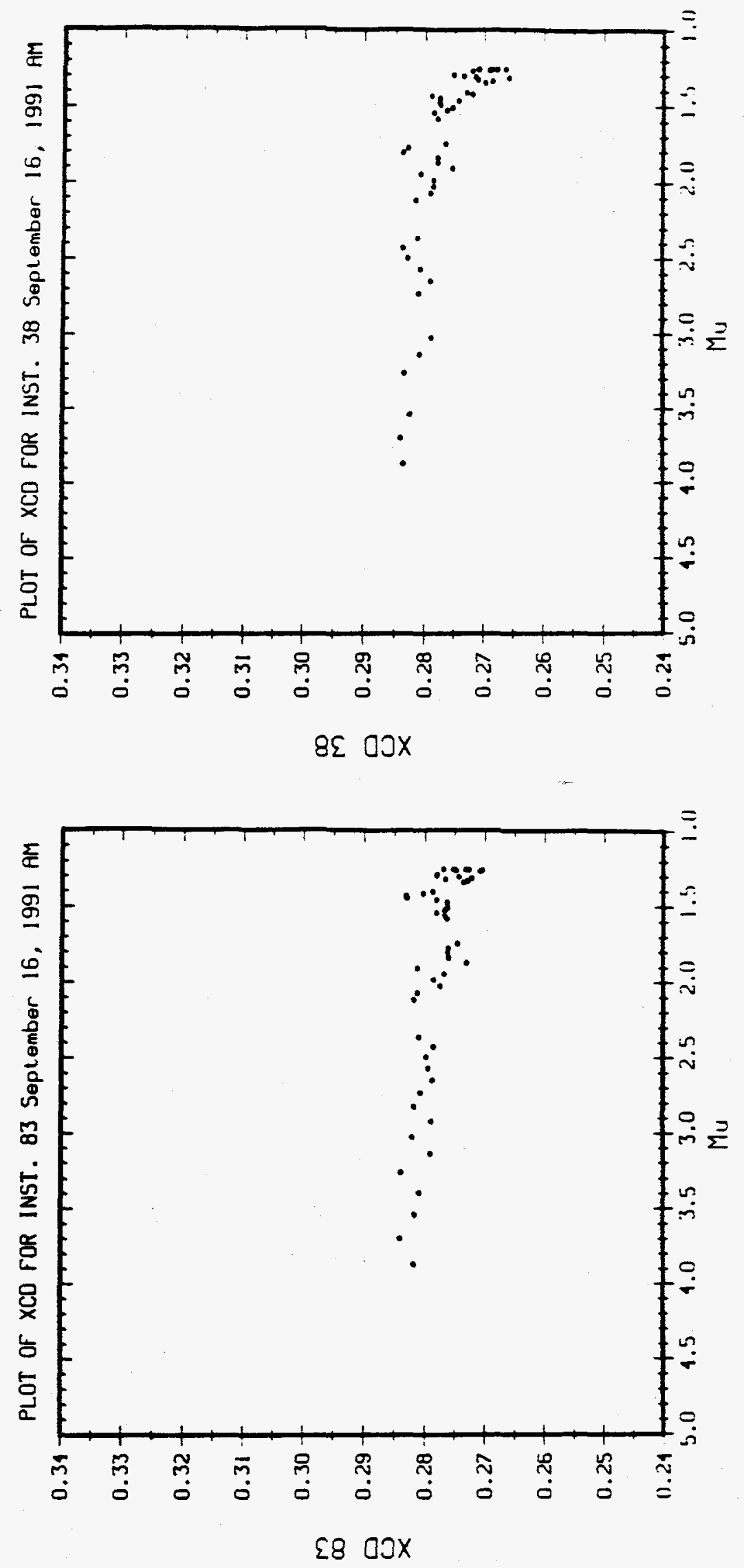


\section{Appendix E}

\section{SAMPLE ARCHIVED}

RE-EVALUATED TOTAL OZONE DATA 
Single spaced output

Create/Overwrite archive file from beginning.

ABSORPTION/SCATTERING COEFFICIENTS USED -NEW II BK WAVELENGTH ABSORPTION SCATTERING

$\begin{array}{rrr}\text { A } & 1.806 & .114 \\ \text { B } & 1.192 & .111 \\ \text { C } & .833 & .109 \\ \text { D } & .374 & .104\end{array}$

ALL ZENITH OBSERVATIONS ARE MULTIPLIED BY .9743

STATION PARAMETERS USED:

STATION NAME

WALLOPS ISLAND, VIRGINIA U.S.A.
EARTH RAD METERS
LONGITUDE DEG MIN SEC DEG MIN SEC
TIME

MEAN ELEVATION HGT O3 ZONE PRESSURE METERS METERS
STATION CODE NUMBER

$6370342.0 \quad N 753038 \quad N \quad 375134$

$5.0 \quad 1014$

7.023000

WAI 107 
Spectral Change

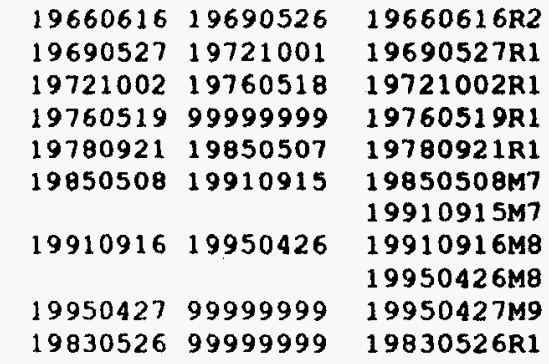

$\begin{array}{llll}19660616 & 19690526 & 19660616 R 2\end{array}$

19721002R1

$19760519 R 1$

$19780921 R 1$

$19850508 \mathrm{M} 7$

$19910915 \mathrm{M} 7$

$19910916 \mathrm{M}$

$19950426 \mathrm{MB}$

$19950427 \mathrm{Mg}$

LAMP DATA

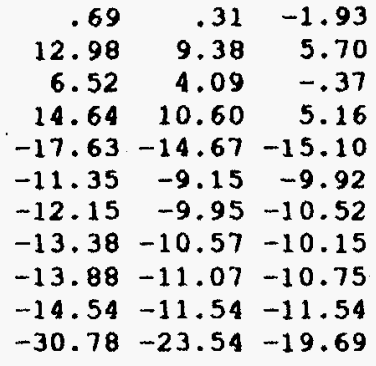

D
B AD
Non Mu-Dependent

Non Mu-Dependent

Non Mu-Dependent

Non Mu-Dependent

Non Mu-Dependent

let Mu-Dependent $\mathrm{N}$-table 0000000000000000 stable Wedge 2nd Mu-Dependent $N$-table

lot Mu-Dependent $\mathrm{N}$-table

2nd Mu-Dependent $\mathrm{N}-\mathrm{t}$ able Mu-Dependent

Non Mu-Dependent
FINAL CORRECTION DATA

$107038 \quad 3.20 \quad 3.002 .30 \quad 3.00 \quad 4.00 \quad 3.00$ $.500000000 \mathrm{E}+01$

$-.128104000 \mathrm{E}+02$

$.149614500 \mathrm{E}+03$

$-.682546700 \mathrm{E}+03$

$.151861300 E+04$

$-.164959100 \mathrm{E}+04$

$.699691800 \mathrm{E}+03$

$107072 \quad 3.20 \quad 4.402$ .

$.590649900 \mathrm{E}+01$

$-.610116700 \mathrm{E}+02$

$.227965000 \mathrm{E}+03$

$-.369381900 \mathrm{E}+03$ $.217393200 \mathrm{E}+03$ $.000000000 \mathrm{E}+00$

$107038 \quad 2.30 \quad 2.002$. $2.302,002$ $.374873000 \mathrm{E}+02$ $.374873000 \mathrm{E}+02$
$-.302157300 \mathrm{E}+03$ $.907730800 \mathrm{E}+03$

$-.120370700 E+04$ $.586796900 \mathrm{E}+03$ $000000000 E+00$

$107086 \quad 2.60 \quad 4.40 \quad 2.00$ $100000000 \mathrm{E}+01$ $-.867591800 \mathrm{E}+01$ $.224114700 \mathrm{E}+02$ $.000000000 \mathrm{E}+00$
$.300000000 \mathrm{E}+0$

$216373600 \mathrm{E}+0$

$-.154505700 \mathrm{E}+02$

$387086100 \mathrm{E}+02$

$-.353299900 \mathrm{E}+02$

$000000000 E+00$ $000000000 \mathrm{E}+00$

$04.40 \quad 3.00 \quad 3.00$ $.200000000 \mathrm{E}+01$

$-.548532200 \mathrm{E}+00$ $553062200 \mathrm{E}+01$

$-.125450800 \mathrm{E}+02$ $.000000000 \mathrm{E}+00$ $.000000000 \mathrm{E}+00$ $000000000 \mathrm{E}+00$

2.001 .001 .00 $.300000000 \mathrm{E}+01$ $.492773700 E+02$ $-.245378400 E+03$ $-.212976800 E+03$ $.000000000 \mathrm{E}+00$ $000000000 E+00$ 2.001 .001 .00 $.100000000 \mathrm{E}+01$ $-.656158100 \mathrm{E}+00$ $.219451500 \mathrm{E}+01$ $.000000000 \mathrm{E}+00$ $.396876700 \mathrm{E}+03$

\section{ADZB CCZB ADZC CCZC CDZB CDZC}

$\begin{array}{llllllll}-.004 & .000 & -.004 & -.001 & .010 & .015 & 850508 & 999999\end{array}$

$\begin{array}{llll}.400000000 E+01 & .500000000 E+01 & .100000000 E+01 & .100000000 E+01\end{array}$

$\begin{array}{llll}.622366900 E+02 & .218707100 E+01 & -.240310900 E+01 & .438201800 E+00\end{array}$

$\begin{array}{llll}-.454926100 \mathrm{E}+03 & -.251828800 \mathrm{E}+02 & .19888850 \mathrm{OE}+02 & .132093200 \mathrm{E}+02\end{array}$

$.122904500 \mathrm{E}+04 \quad .110001300 \mathrm{E}+03 \quad .000000000 \mathrm{E}+00 \quad .000000000 \mathrm{E}+00$

$\begin{array}{llll}-.145351600 \mathrm{E}+04 & -.231785300 \mathrm{E}+03 & .000000000 \mathrm{E}+00 & .000000000 \mathrm{E}+00\end{array}$

$.630647400 \mathrm{E}+03 \quad .252302500 \mathrm{E}+03 \quad .000000000 \mathrm{E}+00 \quad .000000000 \mathrm{E}+00$

$.000000000 \mathrm{E}+00 \quad-.133099000 \mathrm{E}+03 \quad .000000000 \mathrm{E}+00 \quad .000000000 \mathrm{E}+00$ $\begin{array}{llllllll}-.010 & .001 & -.005 & .000 & .005 & .008 & 620618 & 791031\end{array}$

$\begin{array}{lllll}.300000000 \mathrm{E}+01 & .200000000 \mathrm{E}+01 & .200000000 \mathrm{E}+01 & .200000000 \mathrm{E}+01\end{array}$

$384600800 \mathrm{t}+02$

$\begin{array}{llll}.156543000 \mathrm{E}+03 & .171531500 \mathrm{E}+02 & -.226187800 \mathrm{E}+02 & -.212774100 \mathrm{E}+02\end{array}$

$\begin{array}{rrrr}-.285238700 \mathrm{E}+03 & -. .300993400 \mathrm{E}+02 & .468775200 \mathrm{E}+02 & .310679200 \mathrm{E}+02\end{array}$ $.167996900 \mathrm{E}+03 \quad .000000000 \mathrm{E}+00 \quad .000000000 \mathrm{E}+00 \quad .000000000 \mathrm{E}+00$ $.000000000 \mathrm{E}+00 \quad .000000000 \mathrm{E}+00 \quad .000000000 \mathrm{E}+00 \quad .000000000 \mathrm{E}+00$ $.000000000 \mathrm{E}+00 \quad .000000000 \mathrm{E}+00 \quad .000000000 \mathrm{E}+00 \quad .000000000 \mathrm{E}+00$ $.007-.007-.002-.009-.000$

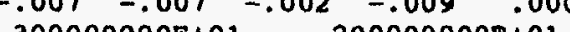
$.300000000 \mathrm{E}+01 \quad .200000000 \mathrm{E}+01$ $-.209209200 \mathrm{E}+02-.221973200 \mathrm{E}+02$ $.118175700 \mathrm{E}+03 \quad .832207100 \mathrm{E}+02$ $-.218672400 \mathrm{E}+03 \quad-.868658200 \mathrm{E}+02$ $.129851900 \mathrm{E}+03 \quad .000000000 \mathrm{E}+00$ $.000000000 \mathrm{E}+00 \quad .000000000 \mathrm{E}+00$ 000000000 .00000 $\begin{array}{lllllll}.000 & -.001 & -.008 & -.004 & .000\end{array}$ $.300000000 \mathrm{E}+01 \quad .100000000 \mathrm{E}+01$ $-.270019400 \mathrm{E}+02 \quad .801869500 \mathrm{E}+01$ $.141438400 \mathrm{E}+03-.201280500 \mathrm{E}+02$ $-.248100000 \mathrm{E}+03 \quad .000000000 \mathrm{E}+00$
$000 \quad 791101840427$

$.000000000 \mathrm{E}+00 \quad .000000000 \mathrm{E}+00$ $000000000 \mathrm{E}+00 \quad .000000000 \mathrm{E}+00$ $.000000000 \mathrm{E}+00 \quad .000000000 \mathrm{E}+00$ $.000000000 \mathrm{E}+00 \quad .000000000 \mathrm{E}+00$ $.000000000 E+00 \quad .000000000 E+00$ $.000000000 \mathrm{E}+00 \quad .000000000 \mathrm{E}+00$ $000000000 \mathrm{E}+00 \quad .000000000 \mathrm{E}+00$ $000 \quad 840430 \quad 850531$

$.000000000 \mathrm{E}+00 \quad .000000000 \mathrm{E}+00$ $.000000000 \mathrm{E}+00 \quad .000000000 \mathrm{E}+00$ $.000000000 \mathrm{E}+00 \quad .000000000 \mathrm{E}+00$ $.000000000 \mathrm{E}+00 \quad .000000000 \mathrm{E}+00$ 
$.000000000 E+00 \quad .000000000 E+00$

$.000000000 \mathrm{E}+00$

$.000000000 E+00$

$138600100 E+03$

$000000000 \mathrm{E}+00$

$.000000000 E+00$

$.000000000 \mathrm{E}+00$

$.000000000 \mathrm{E}+00$

$.000000000 \mathrm{E}+00$ $.000000000 \mathrm{E}+00$

$.000000000 \mathrm{E}+00$

$.000000000 \mathrm{E}+00$

$.000000000 \mathrm{E}+00$

$.000000000 \mathrm{E}+00$

CD MF AND DELTA NC SF DATA

$\begin{array}{rrrrr}107072 & 1.000 & 117.0 & 670623 & 690526 \\ 107072 & 1.000 & 128.0 & 690527 & 721001 \\ 107072 & 1.000 & 123.0 & 721002 & 760518 \\ 107072 & 1.000 & 139.0 & 760519 & 780920 \\ 107038 & 1.000 & 88.0 & 780921 & 840427 \\ 107086 & 1.000 & 100.0 & 840430 & 850531 \\ 107038 & 1.010 & 74.0 & 850603 & 910915 \\ 107038 & 1.020 & 76.0 & 911016 & 950426\end{array}$


$\begin{array}{lllllllllll}139.9 & 139.8 & 139.3 & 53.6 & 53.7 A D D S G Q P & 01 & 100200 & 03 & 91 & \mathrm{H}\end{array}$ $\begin{array}{lllllllllll}79.6 & 79.1 & 79.0 & 53.1 & 52.9 \text { CDDSGQP } & 01 & 100700 & 03 & 91 & \mathrm{H}\end{array}$ $\begin{array}{lllllllllll}117.0 & 116.7 & 116.8 & 46.8 & 46.8 A D D S G Q P & 01 & 120000 & 03 & 91 & \mathrm{H}\end{array}$ $\begin{array}{llllllllllll}67.9 & 67.7 & 67.5 & 46.9 & 46.7 C D D S G Q P & 01 & 120300 & 03 & 91 & \text { H }\end{array}$ $\begin{array}{llllllllll}132.6 & 132.8 & 133.1 & 51.6 & 51.6 A D D S G Q P & 01 & 141400 & 03 & 91 & \mathrm{H}\end{array}$ $\begin{array}{lllllllllll}76.9 & 77.0 & 77.1 & 51.6 & 51.9 \text { CDDSGQP } & 01 & 141700 & 03 & 91 & \mathrm{H}\end{array}$

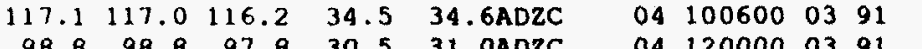

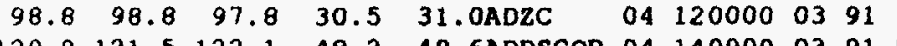
$\begin{array}{lllllllllll}120.9 & 121.5 & 122.1 & 48.2 & 48.6 \text { ADDSGQP } & 04 & 140900 & 03 & 91 \mathrm{H}\end{array}$

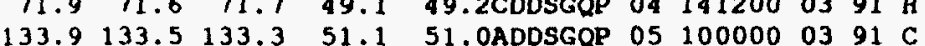
$\begin{array}{llllllllll}76.4 & 75.9 & 75.7 & 50.9 & 50.6 \text { CDDSGQP } & 05 & 100300 & 03 & 91 & \mathrm{C}\end{array}$ $115.0115 .2 \quad 115.5 \quad 45.5 \quad 45.6$ ADDSGQP $05120000 \quad 0391 \mathrm{C}$ $\begin{array}{lllllllllll}66.4 & 66.5 & 66.9 & 45.4 & 45.8 C D D S G Q P & 05 & 120300 & 03 & 91 & \mathrm{C}\end{array}$ $131.4131 .6 \quad 131.8 \quad 50.2 \quad 50.5 A D D S G Q P \quad 05140800 \quad 0391 \mathrm{C}$ $\begin{array}{lllllllllll}76.2 & 76.5 & 76.8 & 50.9 & 51.2 \text { CDDSGQP } & 05 & 141200 & 03 & 91 & \mathrm{C}\end{array}$ $\begin{array}{lllllllll}113.7 & 113.2 & 112.8 & 33.0 & 32.6 \mathrm{ADZC} & 06 & 100000 & 03 & 91\end{array}$ $\begin{array}{lllllllll}98.5 & 98.9 & 98.9 & 29.7 & 30.0 A D 2 C & 06 & 120000 & 03 & 91\end{array}$

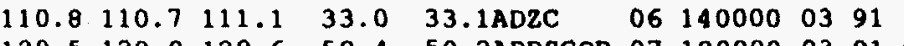
$\begin{array}{lllllllllll}129.5 & 129.0 & 128.6 & 50.4 & 50.2 A D D S G Q P & 07 & 100000 & 03 & 91 & \mathrm{C}\end{array}$ $\begin{array}{llllllllll}74.5 & 74.4 & 74.5 & 50.4 & 50.5 \text { CDDSGOP } & 07 & 100300 & 03 & 91 & \mathrm{C}\end{array}$ $109.2 \quad 109.1 \quad 109.2 \quad 44.6 \quad 44.6$ ADDSGOP $07 \quad 120900 \quad 0391 \mathrm{C}$ $\begin{array}{lllllllllll}63.5 & 63.6 & 63.6 & 44.4 & 44.4 \mathrm{CDDSCOP} & 07 & 121200 & 03 & 91 & \mathrm{C}\end{array}$ $\begin{array}{llllllllll}122.7 & 123.1 & 123.8 & 48.4 & 48.5 A D D S G O P & 07 & 140100 & 03 & 91 & \mathrm{C}\end{array}$ $\begin{array}{llllllllll}72.4 & 71.5 & 71.4 & 48.6 & 48.6 \text { CDDSGQP } & 07 & 140400 & 03 & 91 & \mathrm{C}\end{array}$ $\begin{array}{llllllllll}151.0 & 151.0 & 151.1 & 54.7 & 55.0 A D D S G Q P & 11 & 100000 & 03 & 91 & \mathrm{C}\end{array}$ $\begin{array}{lllllllllll}84.5 & 84.6 & 84.7 & 54.7 & 55.0 C D D S G Q P & 11 & 100300 & 03 & 91 & \mathrm{C}\end{array}$ $\begin{array}{llllllllllll}128.1 & 128.0 & 128.0 & 48.0 & 48.0 A D D S G Q P & 11 & 120000 & 03 & 91 & \mathrm{C}\end{array}$ $\begin{array}{llllllllll}72.0 & 72.5 & 72.6 & 48.0 & 48.1 \mathrm{CDDSGOP} & 11 & 120300 & 03 & 91 \mathrm{C}\end{array}$ $\begin{array}{lllllllllll}143.5 & 143.7 & 144.0 & 52.0 & 52.1 A D D S G Q P & 11 & 140000 & 03 & 91 & \mathrm{C}\end{array}$

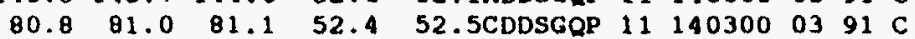
$\begin{array}{lllllllll}141.3 & 141.0 & 140.8 & 52.4 & 52.3 A D D S G Q P & 12 & 100000 & 03 & 91 \mathrm{H}\end{array}$ $\begin{array}{lllllllllll}79.4 & 79.1 & 79.0 & 52.1 & 52.1 \text { CDDSGOP } & 12 & 100300 & 03 & 91 & \mathrm{H}\end{array}$ $121.1 \quad 121.2 \quad 121.5 \quad 46.5 \quad 46.5 A D D S G Q P \quad 12120000 \quad 03 \quad 91 \mathrm{H}$ $\begin{array}{lllllllllll}69.0 & 68.9 & 68.9 & 46.5 & 46.5 \text { CDDSGOP } & 12 & 120300 & 03 & 91 & \mathrm{H}\end{array}$ $\begin{array}{lllllllll}135.8 & 136.1 & 136.5 & 50.0 & 50.1 A D D S G O P & 12 & 140700 & 03 & 91 \mathrm{H}\end{array}$

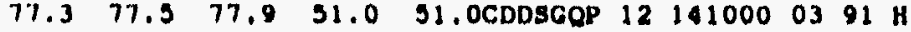
$138.2139 .7135 .7 \quad 38.4 \quad 38.2 A U 2 C \quad 131000000391$ $128.2128 .0127 .9 \quad 37.4 \quad 37.4$ ADZC $\quad 131206000391$ $141.9142 .1141 .940 .1 \quad 40.1$ ADZC 131400000391

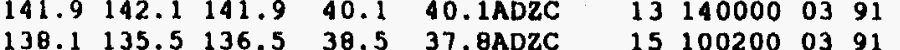
$\begin{array}{lllllllll}138.1 & 135.5 & 136.5 & 38.5 & 37.8 A D Z C & 15 & 100200 & 03 & 91 \\ 121.5 & 122.0 & 120.7 & 34.8 & 34.4 A D Z C & 15 & 120000 & 03 & 91\end{array}$ $\begin{array}{lllllllll}121.5 & 122.0 & 120.7 & 34.8 & 34.4 A D Z C & 15 & 120000 & 03 & 91 \\ 112.4 & 112.6 & 112.8 & 32.0 & 32.5 A D Z C & 18 & 130200 & 03 & 91\end{array}$

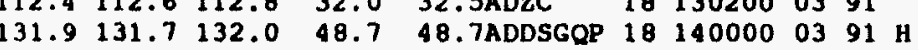

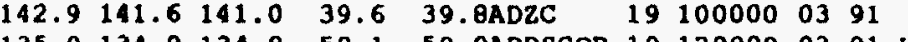

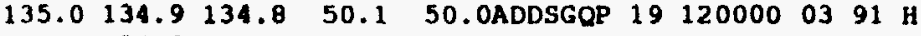
$\begin{array}{llllllllllll}76.5 & 76.5 & 76.5 & 50.1 & 50.1 C D D S G Q P & 19 & 120300 & 03 & 91 & \mathrm{H}\end{array}$ $\begin{array}{llllllllll}151.3 & 151.5 & 151.9 & 55.0 & 55.1 \text { ADDSGOP } & 19 & 140000 & 03 & 91 & \mathrm{H}\end{array}$ $\begin{array}{llllllllll}86.0 & 85.8 & 85.9 & 56.0 & 55.3 C D D S G O P & 19 & 140300 & 03 & 91 & \mathrm{H}\end{array}$

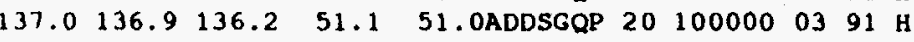
$\begin{array}{llllllllll}77.1 & 76.7 & 76.6 & 50.7 & 50.5 \text { CDDSGQP } & 20 & 100300 & 03 & 91 & \mathrm{H}\end{array}$ $\begin{array}{lllllllll}116.1 & 116.2 & 116.1 & 45.5 & 45.5 A D D S G Q P & 20 & 120000 & 03 & 91 \mathrm{H}\end{array}$ $\begin{array}{lllllllllll}66.7 & 66.6 & 66.5 & 45.6 & 45.4 \text { CDDSGOP } 20 & 120300 & 03 & 91 & \mathrm{H}\end{array}$ $\begin{array}{llllllllll}627.1 & 127.4 & 128.3 & 48.9 & 49.0 A D D S G Q P & 20 & 140000 & 03 & 91 & \mathrm{H}\end{array}$

$\begin{array}{lll}\mathrm{L} & \mathrm{M} & \mathrm{V} \\ \mathrm{L} & \mathrm{M} & \mathrm{V}\end{array}$ I M V

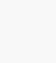
38 WAI 38 WAI 38 WAT 38 WA 38 WAI 38 WAI 38 WA I 
DATE: $95 / 11 / 03$. TIME: 15.11 .17 .

INPUT RECORDS

$\begin{array}{lllll}111.1 & 111.0 & 110.6 & 33.5 & 33.4 \mathrm{ADZC}\end{array}$ $105.1 \quad 104.6 \quad 104.6 \quad 31.6 \quad 31.9 A D Z C$ $\begin{array}{lllll}109.2 & 109.2 & 109.4 & 32.7 & 32.9 A D Z C\end{array}$ $\begin{array}{lllll}107.8 & 107.7 & 108.0 & 32.7 & 32.6 \mathrm{ADZC}\end{array}$

$\begin{array}{lllll}108.5 & 108.0 & 107.7 & 32.6 & 33.0 \mathrm{ADZC}\end{array}$

$\begin{array}{lllll}117.1 & 117.9 & 118.7 & 33.8 & 34.3 A D Z C\end{array}$

$5118.733 .834 .3 \mathrm{ADZC}$

$12 \%, 127.412 \%, 49.0$ 48.6ADDSGOP

$21 \quad 100700 \quad 0391$ $21 \quad 12000003 \quad 91$ $\begin{array}{lllll}21 & 140000 & 03 & 91\end{array}$ 221012000391 221200000391 $22140000 \quad 0391$ 251000000391

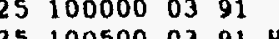
$103.9103 .6 \quad 103.6 \quad 32.5 \quad 32.5 A D Z C \quad 25120200 \quad 0391$ $\begin{array}{llllllllll}126.5 & 126.5 & 126.6 & 48.5 & 48.4 A D D S G Q P & 25 & 140600 & 03 & 91 \mathrm{H}\end{array}$ $\begin{array}{lllllllllll}72.6 & 72.8 & 72.5 & 48.6 & 48.4 C D D S G Q P & 25 & 140900 & 03 & 91 & \mathrm{H}\end{array}$ $\begin{array}{llllllllll}124.7 & 124.0 & 123.9 & 48.1 & 48.0 A D D S G Q P & 26 & 100300 & 03 & 91 & \mathrm{H}\end{array}$ $\begin{array}{lllllllllll}71.2 & 70.9 & 70.9 & 48.4 & 48.0 \text { CDDSGQP } & 26 & 100600 & 03 & 91 & \mathrm{H}\end{array}$ $109.0 \quad 108.9 \quad 109.0 \quad 43.9 \quad 43.8$ ADDSGQP $26 \quad 12020003 \quad 91 \mathrm{H}$ $\begin{array}{llllllllll}120.9 & 121.0 & 121.3 & 47.6 & 47.6 A D D S G Q P & 26 & 140000 & 03 & 91 & \mathrm{H}\end{array}$

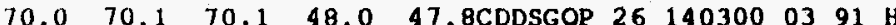
$44.6 C D D S Q P 261205000391$ H $112.1112 .1112 .0 \quad 46.5 \quad 46.5 A D D S G Q P 271021000391$ 65.965 .765 .046 .0 46.1CDDSGQP 271026000391 102.1102 .0102 .0 43.6 43.6ADDSGQ 2710260003 $91 \mathrm{H}$

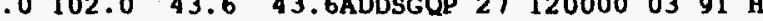
$\begin{array}{lllllllll}111.5 & 111.8 & 111.6 & 46.4 & 46.5 A D D S G Q P & 27 & 140000 & 03 & 91 \mathrm{H}\end{array}$ $\begin{array}{llllllllll}66.0 & 66.1 & 66.6 & 46.5 & 46.6 C D D S G Q P & 27 & 140300 & 03 & 91 & \text { H }\end{array}$ $61.0 \quad 61.0 \quad 61.1 \quad 43.5 \quad 43.5 C D D S G Q P 27 \quad 120600 \quad 0391$ $\begin{array}{lllllllll}92.3 & 91.5 & 91.5 & 27.9 & 27.4 A D Z C & 28 & 100000 & 03 & 91\end{array}$

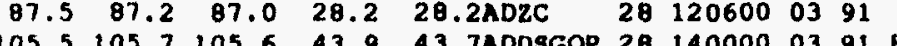
$\begin{array}{lllllllll}62.9 & 62.4 & 62.5 & 44.1 & 43.7 A D D S G Q P & 28 & 140000 & 03 & 91 \mathrm{H}\end{array}$

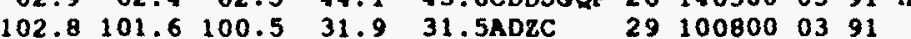

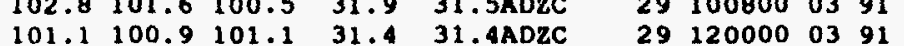

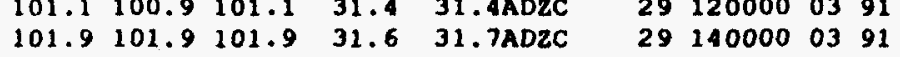

MU

N 1

N2

D

D2

$\begin{array}{lllllllll}L \text { TN V } & 1 & 38 & \text { WAI } & 1.461 & 1.012 & .979 & .225 & .207\end{array}$

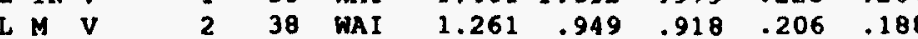

$M$ TN V

$M$ TN V

L $M V$

$M M V$

M TN V

M I'N V

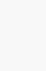

H TN V

H TN V

L. $V$ FOC

L $M V$

L $M V$

. MU*. 350

. MU . 344

.322
.324
.318

.318

MO*. 312

"MU* . 320

.287

.303

MU*.301

.319

.361
.325 
TOTAL AMOUNT OF OZONE MAR 1991 WALLOPS ISLAND, VIRGINIA U.S.A.

\begin{tabular}{|c|c|c|c|c|c|c|c|c|c|c|c|c|c|c|}
\hline YY & GGMMM & LSO00 & YY & GGMMM & LSOOO & YY & GGMMM & LSOOO & YY & GGMMM & $15 S 000$ & $Y Y$ & GGMMM & LSOOO \\
\hline 01 & 15173 & 00336 & 08 & MSG & & 15 & 15155 & 05414 & 22 & 15143 & 05337 & 29 & 15138 & 07319 \\
\hline 01 & 15170 & $20335 *$ & 08 & & & -15 & 17130 & 05424 & -22 & 17125 & 05379 & 29 & 17121 & 05361 \\
\hline-01 & 17142 & 00331 & 08 & & & 15 & & & 22 & 19141 & 05379 & -29 & 19136 & 05325 \\
\hline 01 & 17142 & 20328 * & 08 & & & 15 & & & 22 & & & 29 & & \\
\hline 01 & 19166 & 00330 & 08 & & & 15 & & & 22 & & & 29 & & \\
\hline 02 & MSG & & 09 & MSG & & 16 & MSG & & 23 & MSG & & 30 & MSG & \\
\hline 02 & & & 09 & & & 16 & & & 23 & & & 30 & & \\
\hline 02 & & & 09 & & & 16 & & & 23 & & & 30 & & \\
\hline 02 & & & 09 & & & 16 & & & 23 & & & 30 & & \\
\hline 02 & & & 09 & & & 16 & & & 23 & & & 30 & & \\
\hline 03 & MSG & & 10 & MSG & & 17 & MSG & & 24 & MSG & & 31 & MSG & \\
\hline 03 & & & 10 & & & 17 & & & 24 & & & 31 & & \\
\hline 03 & & & 10 & & & 17 & & & 24 & & & 31 & & \\
\hline 03 & & & 10 & & & 17 & & & 24 & & & 31 & & \\
\hline 03 & & & 10 & & & 17 & & & 24 & & & 31 & & \\
\hline 04 & 15167 & 05323 & -11 & 15160 & 00410 & 18 & 18131 & 05392 & 25 & 15145 & 05367 & & & \\
\hline 04 & 17140 & 05308 & 11 & 15159 & $20407 *$ & -18 & 19144 & 00391 & -25 & 15143 & 00371 & & & \\
\hline-04 & 19161 & 00305 & 11 & 17133 & 00407 & 18 & & & 25 & 17123 & $0.5: 36.5$ & & & \\
\hline 04 & 19162 & $20306 *$ & 11 & 17133 & 20405 & 18 & & & 25 & 19141 & 00.374 & & & \\
\hline 04 & & & 11 & 19150 & 00417 & 18 & & & 25 & 19142 & $20373^{\star}$ & & & \\
\hline 05 & 15168 & 00331 & 12 & 15159 & 00379 & 19 & 15151 & 05439 & 26 & 15143 & 00.359 & & & \\
\hline 05 & 15167 & 20331 * & 12 & 15158 & 20374 * & -19 & 17127 & 00454 & 26 & 15142 & $20353^{*}$ & & & \\
\hline-05 & 17139 & 00338 & -12 & 17133 & 00381 & 19 & 17127 & $20458^{*}$ & 26 & 17123 & 00356 & & & \\
\hline 05 & 17139 & 20339 * & 12 & 17133 & $20378 *$ & 19 & 19143 & 00461 & -26 & 19138 & 00.357 & & & \\
\hline 05 & 19159 & 00345 & 12 & 19152 & 00385 & 19 & 19144 & $20455 *$ & 26 & 19139 & $20350^{*}$ & & & \\
\hline 06 & 15167 & 05318 & 13 & 15158 & 05402 & 20 & 15150 & 00388 & 27 & 15136 & 00322 & & & \\
\hline-06 & 17138 & 05320 & -13 & 17132 & 05439 & 20 & 15149 & $20386^{*}$ & 27 & 15135 & 20324 & & & \\
\hline 06 & 19155 & 05324 & 13 & 19148 & 06444 & -20 & 17127 & 00376 & -27 & 17122 & 00318 & & & \\
\hline 06 & & & 13 & & & 20 & 17127 & 20372 & 27 & 19138 & 00316 & & & \\
\hline 06 & & & 13 & & & 20 & 19143 & 00372 & 27 & 19139 & 20312 * & & & \\
\hline-07 & 15166 & 00320 & 14 & MSG & & 21 & 15146 & 05342 & 28 & 15142 & 05287 & & & \\
\hline 07 & 15164 & 20320 * & 14 & & & 21 & 17126 & 05366 & 28 & 17122 & 05303 & & & \\
\hline 07 & 17137 & 00317 & 14 & & & -21 & 19142 & 05346 & -28 & 19137 & 00.300 & & & \\
\hline 07 & 17137 & $20315 *$ & 14 & & & 21 & & & 28 & 19138 & $20.301 *$ & & & \\
\hline 07 & 19154 & 00325 & 14 & & & 21 & & & 28 & & & & & \\
\hline
\end{tabular}

DATE: $95 / 11 / 03$. TIME: 15.11 .17 
DATE: $95 / 11 / 03$. TIME: 15.11 .27 .

INPUT RECORDS

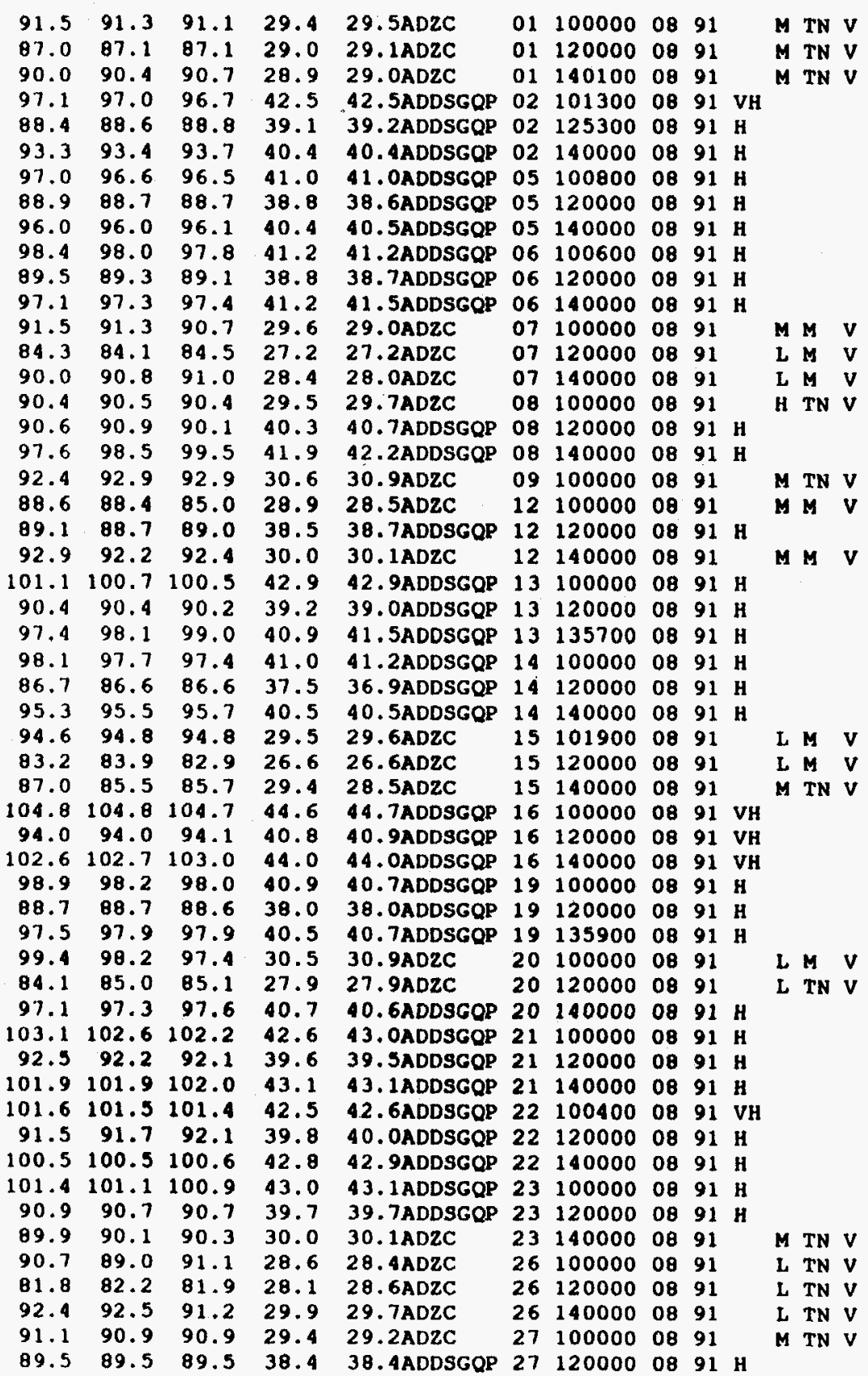

MU

N1

N2

D1

D2

$\begin{array}{llllllll}38 & \text { WAI } & 1.209 & .811 & .786 & .180 & .167\end{array}$

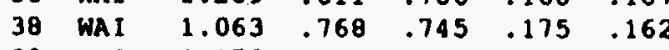

$\begin{array}{lllllll}38 & \text { WAI } & 1.173 & .801 & .777 & .174 & .161\end{array}$

$\begin{array}{lllllll}38 & \text { WAI } & 1.180 & .869 & .844 & .325 & .311\end{array}$

$\begin{array}{lllllll}38 & \text { WAI } & 1.081 & .784 & .760 & .288 & .274\end{array}$

$\begin{array}{lllllll}38 & \text { WAI } & 1.173 & .833 & .809 & .302 & .288\end{array}$

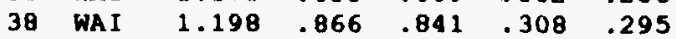

38 WAI $1.070 \quad .785 \quad .762 \quad .283 \quad .269$

38 WAI $1.181 \quad .859 \quad .835 \quad .302 \quad .289$

$\begin{array}{lllllll}38 & \text { WAI } & 1.205 & .880 & .855 & .310 & .297 \\ 38 & \text { WAI } & 1.072 & .791 & .768 & .283 & .270\end{array}$

38 WAI $1.183 \quad .872 \quad .847 .312 \quad .299$

$\begin{array}{lllllll}38 & \text { WAI } & 1.223 & .810 & .785 & .178 & .165\end{array}$

$\begin{array}{lllllll}38 & \text { WAI } & 1.074 & .740 & .717 & .154 & .141\end{array}$

$\begin{array}{lllllll}38 & \text { WAI } & 1.186 & .804 & .779 & .166 & .152\end{array}$

$\begin{array}{llllllll}38 & \text { WAI } & 1.226 & .802 & .777 & .181 & .168\end{array}$

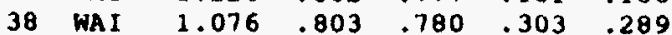

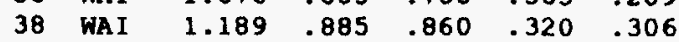

$\begin{array}{lllllll}38 & \text { WAI } & 1.228 & .826 & .800 & .194 & .181\end{array}$

$\begin{array}{lllllll}38 & \text { WAI } & 1.237 & .771 & .745 & .171 & .158 \\ 38 & \text { WAI } & 1.085 & .787 & .763 & .282 & .268\end{array}$

$\begin{array}{lllllll}38 & \text { WAI } & 1.202 & .823 & .798 & .187 & .173\end{array}$

38 WAI $1.239 \quad .908 \quad .882 \quad 329.315$

38 WAI $1.088 .001 \quad 778.087 .074$

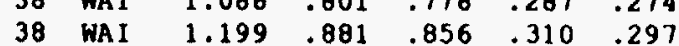

$\begin{array}{lllllll}38 & \text { WAI } & 1.199 & .881 & .856 & .310 & .297 \\ 38 & \text { WAI } & 1.242 & .877 & .851 & .309 & .296\end{array}$

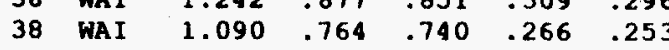

$\begin{array}{lllllll}38 & \text { WAI } & 1.210 & .854 & .829 & .303 & .289\end{array}$

$\begin{array}{lllllll}38 & \text { WAI } & 1.200 & .846 & .821 & .181 & .167\end{array}$

$\begin{array}{lllllll}38 & \text { WAI } & 1.093 & .730 & .707 & .148 & .134 \\ 38 & \text { WAI } & 1.213 & .758 & .733 & .174 & .160\end{array}$

$\begin{array}{lllll}1.249 & 949 & .923 & .348 & .160\end{array}$

$\begin{array}{lllll}1.095 & .839 & .815 & .307 & .293\end{array}$

$\begin{array}{lllll}1.217 & .928 & .903 & .341 & .327\end{array}$

$\begin{array}{lllll}1.258 & .883 & .857 & .306 & .29\end{array}$

$\begin{array}{lllll}1.227 & .877 & .851 & .304 & .290\end{array}$

$\begin{array}{llllll}1.262 & .883 & .857 & .194 & .100\end{array}$

$\begin{array}{lllll}1.106 & .744 & .720 & .162 & .148\end{array}$

$\begin{array}{llllll}1.234 & .873 & .847 & .304 & .290\end{array}$

$\begin{array}{lllll}1.265 & .927 & .901 & .328 & .314\end{array}$

$\begin{array}{lllll}1.109 & .821 & .797 & .292 & .278\end{array}$

$\begin{array}{lllll}1.239 & .920 & .894 & .331 & .317\end{array}$

$\begin{array}{lllll}1.258 & .915 & .889 & .325 & .311\end{array}$

$\begin{array}{lllll}1.113 & .816 & .792 & .296 & .282\end{array}$

$\begin{array}{lllll}1.243 & .905 & .880 & .329 & .315\end{array}$

$\begin{array}{lllll}1.273 & .912 & .085 & .331 & .317\end{array}$

$\begin{array}{lllll}1.116 & .806 & .781 & .294 & .280\end{array}$

$\begin{array}{lllll}1.284 & .800 & .774 & .169 & .155\end{array}$

$\begin{array}{lllll}1.126 & .716 & .692 & 167 & .15\end{array}$

$\begin{array}{llll}1.264 & 818 & 792 \quad 184 \quad .150\end{array}$

$\begin{array}{lllll}1.264 & .818 & .792 & .184 & .170\end{array}$

$\begin{array}{lllll}1.288 & .808 & .781 & .178 & .164\end{array}$

$\begin{array}{lllll}1.129 & .793 & .768 & .280 & .265 \\ 1.269 & .894 & .868 & .310 & .296\end{array}$
.322

$\star \mathrm{MU} * .34$

.331

.308

.307

.312

.315

.316

.316

.317

.317

$. \mathrm{MU} . .337$

.331

.312

.311

.317

.296

.312

.326

.312

.317

.305

.305

.305

$\mathrm{MO}^{\star} .328$

.294

.322

.326
.323

.307

.309
.312

.338

-MU*. 324

.308

.317

.319

. .318

.313

.310

.305

.307

.302

"MU*.298

.310

.301

.304
.307 
DATE: $95 / 11 / 03$. TIME: 15.11 .27

\section{INPUT RECORDS}

$\begin{array}{lllllllllll}98.1 & 98.6 & 98.8 & 41.0 & 41.7 A D D S G Q P & 28 & 101400 & 08 & 91 \mathrm{H}\end{array}$ $\begin{array}{lllllllllll}90.1 & 90.1 & 90.2 & 38.2 & 38.2 A D D S G Q P & 28 & 120000 & 08 & 91 & \mathrm{H}\end{array}$ $\begin{array}{llllllllll}98.9 & 99.1 & 99.6 & 41.4 & 41.5 A D D S G Q P & 28 & 135700 & 08 & 91 & \mathrm{H}\end{array}$

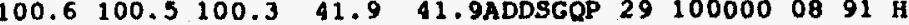
$\begin{array}{lllllllllll}90.7 & 90.7 & 90.7 & 39.0 & 39.0 A D D S G Q P & 29 & 120000 & 08 & 91 & \mathrm{H}\end{array}$ $100.0100 .2100 .3 \quad 42.0 \quad 42.0 A D D S G O P 291400000891 \mathrm{H}$ $101.7101 .5101 .4 \quad 43.4 \quad 43.4 A D D S G O P 30100000$ OB $91 \mathrm{VH}$ $101.7101 .5101 .4 \quad 43.4$ 43.4ADDSGOP $30100000891 \mathrm{VH}$
MU N1 N2

D1

$\begin{array}{llllllll}38 & \text { WAI } & 1.255 & .885 & .858 & .312 & .298 \\ 8 & \text { WAI } & 1.133 & .799 & .774 & .277 & .263 \\ 8 & \text { WAI } & 1.267 & .892 & .865 & .313 & .299 \\ 8 & \text { WAI } & 1.296 & .905 & .878 & .318 & .304 \\ 8 & \text { WAI } & 1.137 & .805 & .780 & .286 & .272 \\ 8 & \text { WAI } & 1.280 & .902 & .875 & .319 & .305 \\ 8 & \text { WAI } & 1.301 & .916 & .889 & .334 & .320 \\ 8 & \text { WAI } & 1.178 & .837 & .811 & .304 & .290\end{array}$

.305

.308

.305

.302

.305

.304

.298 
TOTAL AMOUNT OF OZONE AUG 1991 WALLOPS ISLANI, VIRGINIA U.S.A.

\begin{tabular}{|c|c|c|c|c|c|c|c|c|c|c|c|c|c|c|}
\hline YY & CGMMM & LSOOO & YY & GGMMM & LSOOO & YY & GGMMM & LSOOOO & $Y Y$ & GGMMM & 1.5000 & $Y Y$ & GGMMM & LSOOO \\
\hline 01 & 15121 & 05322 & 08 & 15123 & 05312 & 15 & 15120 & 05342 & 22 & 15126 & 00314 & 29 & 15130 & 00302 \\
\hline 01 & 17106 & 05347 * & -08 & 17108 & 00311 & -15 & 17109 & $05328^{\star}$ & -22 & 17111 & 00313 & 29 & 17114 & 00305 \\
\hline-01 & 19117 & 05331 & 08 & 19119 & 00318 & 15 & 19121 & 05294 & 22 & 19124 & 00310 & -29 & 19128. & .00304 \\
\hline 01 & & & 08 & & & 15 & & & 22 & & & 29 & & \\
\hline 01 & & & 08 & & & 15 & & & 22 & & & 29 & & \\
\hline 02 & 15118 & 00308 & -09 & 15123 & 05317 & 16 & 15125 & 00322 & -23 & 15127 & $00: 105$ & 30 & 15130 & 00298 \\
\hline-02 & 18108 & 00307 & 09 & & & 16 & 17110 & 00326 & 23 & 17112 & 00307 & -30 & 16118 & 00302 \\
\hline 02 & 19117 & 00303 & 09 & & & -16 & 19122 & 00323 & 23 & 19125 & 05302 & 30 & & \\
\hline 02 & & & 09 & & & 16 & & & 23 & & & 30 & & \\
\hline 02 & & & 09 & & & 16 & & & 23 & & & 30 & & \\
\hline 03 & MSG & & 10 & MSG & & 17 & MSG & & 24 & MSG & & 31 & MSG & \\
\hline 03 & & & 10 & & & 17 & & & 24 & & & 31 & & \\
\hline 03 & & & 10 & & & 17 & & & 24 & & & 31 & & \\
\hline 03 & & & 10 & & & 17 & & & 24 & & & 31 & & \\
\hline 03 & & & 10 & & & 17 & & & 24 & & & 31 & & \\
\hline 04 & MSG & & 11 & MSG & & 18 & MSG & & 25 & MSG & & & & \\
\hline 04 & & & 11 & & & 18 & & & 25 & & & & & \\
\hline 04 & & & 11 & & & 18 & & & 25 & & & & & \\
\hline 04 & & & 11 & & & 18 & & & 25 & & & & & \\
\hline 04 & & & 11 & & & 18 & & & 25 & & & & & \\
\hline 05 & 15120 & 00312 & 12 & 15124 & 05296 & 19 & 15126 & 00307 & -26 & 15128 & 05303 & & & \\
\hline-05 & 17107 & 00315 & -12 & 17109 & 00312 & -19 & 17110 & 00309 & 26 & 17113 & $05298^{*}$ & & & \\
\hline 05 & 19118 & 00316 & 12 & 19120 & 05326 & 19 & 19123 & 00312 & 26 & 19126 & 05310 & & & \\
\hline 05 & & & 12 & & & 19 & & & 26 & & & & & \\
\hline 05 & & & 12 & & & 19 & & & 26 & & & & & \\
\hline 06 & 15121 & 00316 & 13 & 15124 & 00312 & 20 & 15126 & 05338 & 27 & 15129 & 05301 & & & \\
\hline-06 & 17107 & 00317 & -13 & 17109 & 00317 & 20 & 17111 & $05324^{k}$ & -27 & 17113 & 0):IC 4 & & & \\
\hline 06 & 19118 & 00317 & 13 & 19120 & 00319 & -20 & 19123 & 00308 & 27 & 19127 & $00: 107$ & & & \\
\hline 06 & & & 13 & & & 20 & & & 27 & & & & & \\
\hline 06 & & & 13 & & & 20 & & & 27 & & $\because$ & & & \\
\hline 07 & 15122 & 05317 & 14 & 15124 & 00305 & 21 & 15127 & 00317 & 28 & 15126 & 00305 & & & \\
\hline-07 & 17107 & 05337 * & -14 & 17109 & 00305 & 21 & 17111 & 00319 & 28 & 17113 & 00308 & & & \\
\hline 07 & 19119 & 05331 & 14 & 19121 & 00305 & -21 & 19124 & 00318 & -28 & 19127 & 00305 & & & \\
\hline 07 & & & 14 & & & 21 & & & 28 & & & & & \\
\hline 07 & & & 14 & & & 21 & & & 28 & & & & & \\
\hline
\end{tabular}

DATE: $95 / 11 / 03$. TIME: 15.11 .27 . 